\title{
CONTRIBUIÇÃO AO ESTUDO DAS CÚPULAS TRELIÇADAS UTILIZANDO ELEMENTOS TUBULARES EM AÇO
}

\author{
ADRIANO MÁRCIO VENDRAME
}

Dissertação apresentada à Escola de Engenharia de São Carlos da Universidade de São Paulo, como parte dos requisitos para obtenção do Título de Mestre em Engenharia de Estruturas

ORIENTADOR: Prof. Dr. Roberto Martins Gonçalves

São Carlos

1999 
Class. TESE-EESC
cutt. $\frac{6190}{\text { Tombo } .0032199}$

Ficha catalográfica preparada pela Seção de Tratamento da Informação do Serviço de Biblioteca - EESC/USP
Vendrame, Adriano Márcio
Contribuição ao estudo das cúpulas treliçadas utilizando elementos tubulares em aço / Adriano Márcio Vendrame. -- São Carlos, 1999.

Dissertação (Mestrado) -- Escola de Engenharia de São Carlos-Universidade de São Paulo, 1999.

Área: Engenharia de Estruturas.

Orientador: Prof. Dr. Roberto Martins Gonçalves.

1. Estruturas metálicas. 2. Estruturas espaciais.

3. Cúpulas treliçadas. 4. Elementos tubulares.

5. Variação de inércia. 6. Sistemas de ligações.

7. Análise numérica. I. Título. 
Candidato: Engenheiro ADRIANO MARCIO VENDRAME

Dissertação defendida e aprovada em 25-03-1999 pela Comissão Julgadora:

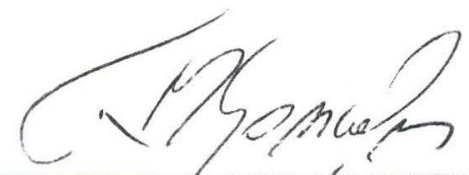

Prof. Doutor ROBERTO MARTINS GONÇALVES (Orientador)

(Escola de Engenharia de São Carlos - Universidade de São Paulo)

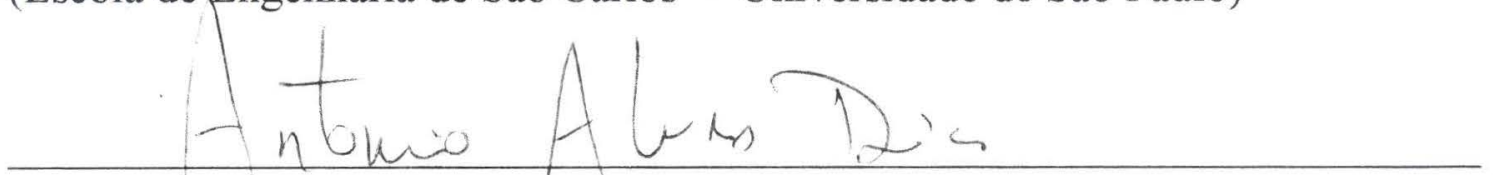

\section{Prof. Doutor ANTONIO ALVES DIAS}

(Escola de Engenharia de São Carlos - Universidade de São Paulo)

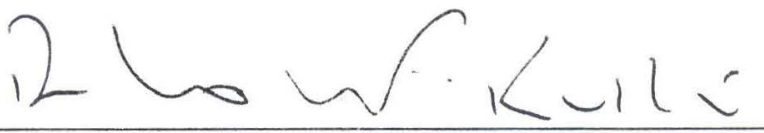

Prof. Doutor RICARDO HALLAL FAKURY

(Universidade Federal de Minas Gerais - UFMG)

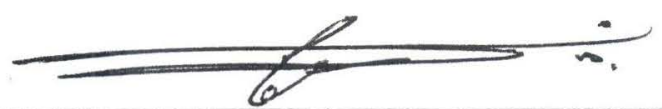

Prof. Titular CARLITO CALIL JUNIOR

Coordenador da Área de Engenharia de Estruturas

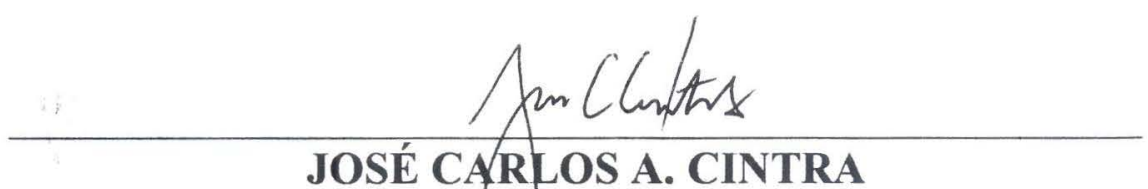

\section{JOSÉ CARLOS A. CINTRA}

Presidente da Comissãa de Pós-Graduação da EESC 
À Aparecida Cezário Vendrame.

Exemplo de mãe e de mulher. 


\section{AGRADECIMENTOS}

Ao Professor Roberto Martins Gonçalves pela dedicação e paciência na orientação deste trabalho. Levo comigo a admiração e a amizade conquistada neste breve período de mestrado.

Aos professores José Jairo de Sales e Maximiliano Malite pela atenção sempre dispensada.

Aos demais professores e funcionários do Departamento de Engenharia de Estruturas, pela solicitude e presteza em todos os momentos de necessidade.

Ao conselho Nacional de Desenvolvimento Científico e Tecnológico CNPq - pela bolsa de estudo concedida.

Ao meu companheiro de moradia, Alonso Droppa Júnior, pela convivência harmoniosa e aprendizado mútuo.

Aos colegas, agradeço àqueles que foram apenas colegas e principalmente aos que se tornaram grandes amigos.

À Aline Passos de Azevedo pela grande amizade desenvolvida neste período.

À minha mãe Aparecida Vendrame e irmãs Adriana e Aline Vendrame, exemplo de família.

Ao meu pai Alvarindo Vendrame e as avós Fides Delmônaco Vendrame e Idalina Cezário Casari, in memoriam. Três grandes pessoas que, pelo que fizeram por mim, permanecerão imortais em meus pensamentos. 


\section{SUMÁRIO}

RESUMO

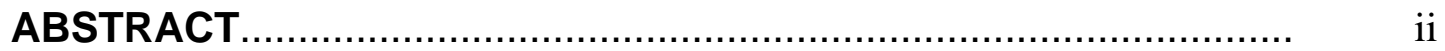

LISTA DE FIGURAS.....................................................................

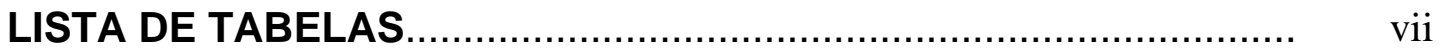

CAPÍTULO 1 - APRESENTAÇÃO...................................................... 01

CAPÍTULO 2 - ASPECTOS GERAIS SOBRE ESTRUTURAS 03 ESPACIAIS - CÚPULAS

2.1 Histórico ................................................................. 03

2.2 Desenvolvimento dos tipos de cúpulas............................... 05

2.3 Descrição dos tipos mais utilizados.................................... 06

2.3.1 Cúpulas nervuradas.......................................... 06

2.3.2 Cúpulas Schwedler............................................. 07

2.3.3 Cúpulas com malha "three-way"......................... 08

2.3.4 Cúpulas lamelares.............................................. 09

2.3.5 Cúpulas geodésicas......................................... 10

2.4 Cúpulas mais utilizadas no Brasil...................................... 12

2.5 Comportamento de cúpulas treliçadas............................... 15

2.6 Análise estática.............................................................. 17

2.7 Alguns aspectos de projeto e execução.............................. 18

2.7.1 Escolha da configuração adequada.................... 18

2.7.2 Ações de projeto................................................ 18

2.7.3 Fabricação...................................................... 19

2.74 Acabamento e pintura ...................................... 19

2.7.5 Montagem........................................................ 20 
CAPÍTULO 3 - SISTEMAS DE LIGAÇÃO......................................... 25

3.1 Apresentação de vários sistemas de ligação...................... 26

3.2 Apresentação de sistemas de ligação utilizados no Brasil.

3.2.1 Nó típico....................................................... 31

3.2.2 Nó com chapa complementar............................ $\quad 34$

3.2.3 Nó composto por chapas (nó de aço)................. $\quad 35$

3.2.4 Nó com chapa de extremidade........................... $\quad 36$

3.3 Comentários finais............................................................ 38

CAPÍTULO 4 - ANÁLISE NUMÉRICA DO NÓ TíPICO........................ 40

4.1 Descrição do protótipo ensaiado........................................ 42

4.1.1 Instrumentação e metodologia do ensaio............ 44

4.2 Comentários sobre o ensaio do protótipo........................... $\quad 46$

4.3 Modelagem da extremidade da barra................................ 49

4.4 Descrição dos elementos utilizados................................... 50

4.4.1 Elemento finito de casca.................................. 50

4.4.2 Elemento finito de barra................................... 51

4.5 Critérios para análise não linear........................................ 53

4.5.1 Não linearidade geométrica................................ 53

4.5.2 Não linearidade física....................................... 54

4.6 Apresentação dos modelos analisados e resultados.......... $\quad 55$

4.6.1 Construção dos modelos..................................... 55

4.6.2 Modelos analisados........................................ 57

4.7 Comparação entre resultados teóricos e experimentais..... 74

CAPÍTULO 5 - CONSIDERAÇÕES SOBRE PROJETOS DE

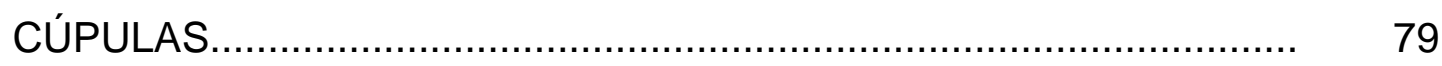

5.1 Descrição da estrutura analisada...................................... 80

5.2 Ações consideradas no projeto............................................ 84 
5.2.1 Ações permanentes..................................... 84

5.2 .2 Ações variáveis.......................................... 84

5.2.2.1 Ações devido ao vento....................... 84

5.3 Cálculo da ação do vento para cúpula estudada............... 88

5.4 Resumo das forças aplicadas á estrutura........................ 92

5.5 Pré-dimensionamento............................................ 94

5.6 Obtenção dos esforços.............................................. 96

5.7 Apresentação dos esforços....................................... 97

5.8 Dimensionamento.................................................... 100

5.9 Resultados....................................................... 104

5.10 Estudo da ruína progressiva........................................ 106

5.10.1 Análise da região 1 (peso próprio+sobrecarga) 108

5.10.2 Análise da região 1 (peso próprio+vento)......... 112

5.10.3 Análise da região 2 (peso próprio+sobrecarga) 114

5.10.4 Análise da região 2 (peso próprio+vento)......... 116

CAPÍTULO 6 - CONCLUSÕES...................................................... 119

REFERÊNCIAS BIBLIOGRÁFICAS .......................................... 123 
RESUMO

VENDRAME, A. M. Contribuição ao estudo das cúpulas treliçadas utilizando elementos tubulares em aço. São Carlos, 1999. Dissertação (Mestrado) - Escola de Engenharia de São Carlos, Universidade de São Paulo.

Este trabalho apresenta um estudo sobre as estruturas espaciais em forma de cúpulas abordando os seguintes aspectos: histórico, desenvolvimento, descrição dos tipos mais utilizados, comportamento, análise e alguns aspectos de projeto e execução. Enfatizam-se as cúpulas constituídas por elementos tubulares com seção transversal circular e, em particular, as que necessitam da estampagem da extremidade de seus elementos para confecção do sistema de ligação. Descrevem-se vários sistemas de ligação utilizados em vários países e os utilizados no Brasil. A influência da variação de inércia causada pela estampagem das barras foi estudada via método dos elementos finitos com a devida modelagem da região afetada. A região modelada foi inserida em uma treliça espacial plana e seus resultados comparados com resultados experimentais desta estrutura. Apresentam-se também, os procedimentos básicos para elaboração do projeto de uma cúpula considerando as hipóteses utilizadas nos escritório de projeto, ou seja, comportamento elástico linear e nós rotulados. Para a mesma estrutura, um breve estudo sobre ruína progressiva, é apresentado.

Palavras-chaves: Estruturas metálicas, estruturas espaciais, cúpulas treliçadas, elementos tubulares, variação de inércia, ligações, análise numérica. 


\begin{abstract}
VENDRAME, A. M. Contribution to the study of braced domes with steel tubular elements. São Carlos, 1999. Dissertação (Mestrado) - Escola de Engenharia de São Carlos, Universidade de São Paulo.
\end{abstract}

This research presents a study about dome space structures about the following aspects: history, development, description of the more utilized types, behavior, analysis and some project and design aspects. It's emphasized the tubular element domes with circular section, particularly, those which need stamping at the end to wake the joint system. It's described many joint systems which are utilized in several countries and also in Brazil. The variable stiffness influence caused by the stamping on the bar ends was studied using the Finite Element Method by a suitable model of the affected region. The modeled region was inserted into a plane space truss and the analysis results were compared to the experimental values. It's also presented the basic procedures to dome project development, considering linear-static behavior. For the same model, a short study about failure downfall is presented.

Keywords: Steel structures, space structures, braced domes, tubular elements, variable stiffness, connection systems, numerical analysis. 


\section{LISTA DE FIGURAS}

Figura 2.1 Exemplo de cúpula nervurada............................................ 07

Figura 2.2 Exemplo de cúpula Schwedler.......................................... 08

Figura 2.3 Exemplo de cúpula com malha "three-way"......................... 09

Figura 2.4 Exemplo de cúpula constituída por lamelas.......................... 10

Figura 2.5 Exemplo de cúpula geodésica.......................................... 12

Figura 2.6 Malha utilizada em cúpulas compostas por elementos tubulares...................................................................... 13

Figura 2.7 Detalhe do nó típico............................................................ 14

Figura 2.8 Exemplo de cúpula utilizada no Brasil................................ 14

Figura 2.9 Sistema de força agindo sobre a superfície da cúpula......... 15

Figura 2.10 Configurações de cúpulas treliçadas.................................. 16

Figura 2.11 Montagem por elemento............................................... 21

Figura 2.12 Montagem por conjuntos parciais.................................... 22

Figura 2.13 Montagem por içamento................................................ 23

Figura 3.1 Detalhe do nó com ligação soldada..................................... 27

Figura 3.2 Sistemas de ligação utilizados em cúpulas......................... 29

Figura 3.3 Nó típico.................................................................... 32

Figura 3.4 Plastificação da extremidade da barra................................ 33

Figura 3.5 Cúpulas com sistema de ligação típico............................... 33

Figura 3.6 Nó típico com chapa complementar................................... 34

Figura 3.7 Nó de aço...................................................................... 35

Figura 3.8 Flambagem dos elementos que constituem o protótipo....... $\quad 36$

Figura 3.9 Detalhe esquemático do nó com chapa de extremidade...... 37

Figura 3.10 Ligação com chapa de ponteira........................................ 38

Figura 4.1 Exemplo de cúpulas utilizadas em nosso país..................... 40

Figura 4.2 Detalhe de montagem da cúpula...................................... 41

Figura 4.3 Características e dimensões do protótipo ensaiado............. 43

Figura 4.4 Protótipo montado no laboratório....................................... $\quad 44$

Figura 4.5 Esquema da instrumentação da estrutura........................... 45 
Figura 4.6 Detalhe da instrumentação da estrutura.......................... 46

Figura 4.7 Plastificação da extremidade da barra.............................. 46

Figura 4.8 Deslocamento teórico e experimental do nó central............ 47

Figura 4.9 Deformação de compressão média na seção da barra........ 47

Figura 4.10 Modelagem da extremidade da barra.......................... 49

Figura 4.11 Elemento SHELL43............................................. 50

Figura 4.12 Elemento BEAM24 ............................................. 51

Figura 4.13 Utilização do SHELL43 com BEAM24......................... 52

Figura 4.14 Detalhe da "escravização" dos nós ............................... 52

Figura 4.15 Verificação do acoplamento entre elementos de casca e barra ..................................................................... 53

Figura 4.16 Curva tensão-deformação do material......................... 54

Figura 4.17 Modelagem do nó típico completo.................................. 55

Figura 4.18 Região transformada em "pacote rígido" ........................ 56

Figura 4.19 Posições dos nós com elementos de casca..................... 57

Figura 4.20 Detalhe da posição do nó típico inserido na estrutura....... 58

Figura 4.21 Deslocamento do nó central da treliça........................... 59

Figura 4.22 Tensões para várias etapas de carregamento................. 62

Figura 4.23 Tensões axiais da extremidade da barra........................ 63

Figura 4.24 Detalhe da posição do nó típico inserido na estrutura....... 64

Figura 4.25 Deslocamento do nó central da treliça............................ 65

Figura 4.26 Tensões para várias etapas de carregamento.................. 68

Figura 4.27 Tensões axiais da extremidade da barra........................ 69

Figura 4.28 Detalhe da posição do nó inserido na estrutura............... 70

Figura 4.29 Deslocamento do nó central da treliça............................ 71

Figura 4.30 Tensões para várias etapas de carregamento.................. 72

Figura 4.31 Rotação excessiva e plastificação da região nodal............ 73

Figura 4.32 Tensões axiais nas extremidades das barras................. 73

Figura 4.33 Posição dos nós e barras analisados............................. 75

Figura 4.34 Deslocamento teórico e experimental - nó central............ 75

Figura 4.35 Deslocamento teórico e experimental - nó extremidade.... 76

Figura 4.36 Deformação teórica e experimental - barra 3................. 77 


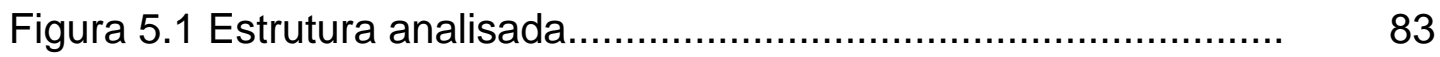

Figura 5.2 Gráficos de isopletas da velocidade básica do vento........... 86

Figura 5.3 Resumo dos coeficientes de pressão................................. 91

Figura 5.4 Pré-dimensionamento dos elementos................................ $\quad 95$

Figura 5.5 Elemento BEAM4....................................................... 96

Figura 5.6 Esforços nos elementos da cúpula para combinação 1....... 98

Figura 5.7 Esforços nos elementos da cúpula para combinação 2...... 100

Figura 5.8 Posição das barras usadas para o dimensionamento.......... 101

Figura 5.9 Barras usadas para o dimensionamento........................... 101

Figura 5.10 Deslocamento devido ao peso próprio.............................. 104

Figura 5.11 Deslocamento devido à sobrecarga................................ 104

Figura 5.12 Deslocamento devido ao vento..................................... 105

Figura 5.13 Deslocamento devido ao peso próprio + vento.................. 105

Figura 5.14 Detalhe da estrutura com as regiões estudadas............... 107

Figura 5.15 Ponto de medição de deslocamentos................................ 108

Figura 5.16 Esforços e deslocamentos da região 1............................ 109

Figura 5.17 Esforços e deslocamentos após a retirada de uma barra.. 109

Figura 5.18 Esforços e deslocamentos após a retirada das barras rompidas.................................................................... 110

Figura 5.19 Detalhe da ruína na região analisada............................... 111

Figura 5.20 Esforços e deslocamentos da região 1........................... 112

Figura 5.21 Esforços e deslocamentos após a retirada de uma barra.. 112

Figura 5.22 Esforços e deslocamentos após a retirada das barras

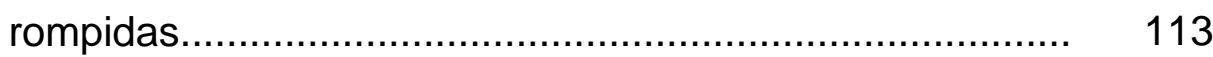

Figura 5.23 Detalhe da ruína na região analisada.............................. 113

Figura 5.24 Esforços e deslocamentos da região 2............................ 114

Figura 5.25 Esforços e deslocamentos após a retirada de uma barra.. 114

Figura 5.26 Esforços e deslocamentos após a retirada das barras rompidas.

Figura 5.27 Detalhe da ruína na região analisada.............................. 115

Figura 5.28 Esforços e deslocamentos da região 2........................... 116

Figura 5.29 Esforços e deslocamentos após a retirada de uma barra.. 116 
Figura 5.30 Esforços e deslocamentos após a retirada das barras rompidas.

Figura 5.31 Detalhe da ruína na região analisada........ 


\section{LISTA DE TABELAS}

Tabela 3.1 Resumo dos sistemas de ligação....................................... $\quad 30$

Tabela 4.1 Elementos utilizados no protótipo ensaiado........................ 43

Tabela 5.1 Resumo das ações aplicadas na estrutura......................... 93

Tabela 5.2 Dimensionamento de algumas barras da cúpula................ 103

Tabela 5.3 Deslocamentos nodais Região 1..................................... 111

Tabela 5.4 Deslocamentos nodais Região 1 ....................................... 113

Tabela 5.5 Deslocamentos nodais Região 2................................... 115

Tabela 5.6 Deslocamentos nodais Região 2..................................... 117 


\section{Apresentação}

A proposição deste trabalho está relacionada com a crescente utilização, em nosso país, de cúpulas constituídas por elementos tubulares de seção transversal circular e, mais que isto, devido aos sistemas de ligação empregados para unir os elementos que compõem estas estruturas.

O estudo das cúpulas vem complementar a linha de pesquisa sobre estruturas espaciais planas ${ }^{1}$ em desenvolvimento na EESC-USP ${ }^{2}$, com intuito de conhecer o comportamento dessas estruturas quando utilizam o sistema de ligação denominado nó tipico ${ }^{3}$.

Esta linha de pesquisa teve início devido a uma série de acidentes com estruturas espaciais planas - como por exemplo o colapso global da estrutura do Centro de Convenções de Manaus - AM, observado alguns dias após a colocação das telhas de cobertura e na ausência de vento - com docentes envolvidos em assessorias para a determinação das causas do colapso.

\footnotetext{
${ }^{1}$ Estruturas espaciais planas: usualmente utilizada para definir estruturas metálicas de cobertura formadas por duas camadas paralelas de barras (banzos) ligadas entre si por outras barras (diagonais), não caracterizando um plano principal para as barras que compõem a estrutura resistente.

${ }^{2}$ EESC: Escola de Engenharia de São Carlos da Universidade de São Paulo

${ }^{3}$ Nó típico: sistema formado pela sobreposição das extremidades estampadas das barras unidas por um único parafuso.
} 
Até a presente data, foram publicadas duas dissertações de mestrado e diversos artigos sobre estruturas espaciais e encontram-se em andamento duas dissertações e um doutoramento analisando, entre outros aspectos, o comportamento global e os nós destas estruturas.

A análise e discussão de estruturas espaciais em forma de cúpulas devem ser abordadas de maneira ampla pelas particularidades deste tipo de estruturas, o que limita observações gerais ou mesmo recomendações.

Deixa-se claro que, apesar deste trabalho iniciar o assunto sobre cúpulas constituídas por elementos tubulares de seção circular, houve a necessidade de considerações e análises das estruturas espaciais planas, devido a necessidade de verificar os resultados das análises numéricas do nó típico, pois somente existem resultados experimentais de protótipos dessas estruturas ensaiadas no Laboratório de Estruturas da EESC-USP.

Quanto ao conteúdo deste trabalho, no segundo capítulo estão apresentados os aspectos gerais das estruturas em forma de cúpulas quanto ao seu histórico, desenvolvimento de várias configurações, tipos mais utilizados, comportamento destas estruturas, análise e considerações para projeto.

Já no terceiro capítulo, apresentam-se vários sistemas de ligação utilizados em todo o mundo para estruturas espaciais, assim como uma breve descrição dos sistemas mais utilizados no Brasil.

No quarto capítulo são apresentadas as análises e os resultados da simulação numérica dos nós típicos com elementos finitos de casca para melhor conhecimento da distribuição de tensões nesta região.

No quinto capítulo, é apresentado um breve roteiro de projeto e dimensionamento dos elementos de uma cúpula de $80,8 \mathrm{~m}$ que apoia sobre colunas de concreto de $100 \times 50 \mathrm{~cm}$ e um breve estudo da ruína progressiva desta estrutura.

Finalmente apresentam-se algumas conclusões de caráter geral sobre as cúpulas e análise do nó típico. 


\section{Aspectos gerais sobre estruturas espacias - Cúpulas}

\section{1- Histórico}

As coberturas para grandes vãos sempre fascinaram arquitetos e engenheiros e as cúpulas, por apresentarem um sistema estrutural eficiente e econômico, são freqüentemente usadas pelos projetistas.

Segundo MAKOWSKI (1984), as cúpulas têm sido usadas pelos arquitetos desde os tempos remotos e, provavelmente, as primeiras indicações do uso dessas estruturas foram encontradas nas ruínas do palácio de Senna-cheribbo em Nineveh, Iraque (705-681 AC).

O estudo realizado por Balwin, em 1950, apresenta que as cúpulas tiveram razões arquitetônicas e religiosas para serem utilizadas. Ele provou que a cúpula não era simplesmente uma forma prática de utilizar a alvenaria como elemento construtivo, mas que possuía um valor simbólico especial, fazendo dela um fator primordial de grandes estilos de arquitetura Bizantino, Islâmico e Indiano - traduzindo o conceito de grandes vãos, associado ao volume construído. 
O desenvolvimento deste tipo de estruturas está associado com os materiais disponíveis em cada época histórica. $\mathrm{Na}$ antigüidade as cúpulas eram construídas em pedras naturais que foram substituídas por alvenaria de tijolos, com o passar do tempo; a seguir, já na Idade Média, utilizou-se a madeira para construções de cúpulas sendo que algumas dessas estruturas ainda podem ser vistas na Alemanha, França, Itália, Rússia e Escandinava.

Com o surgimento do ferro como material estrutural, em 1811 construiu-se uma cúpula pela primeira vez quando Bélanger e Brunet cobriram a parte central do Corn Market, em Paris.

O concreto foi muito utilizado para a construção de cúpulas mas, devido a sua baixa resistência à tração, eram necessárias grandes espessuras. Podemos citar, como exemplo, a cúpula de concreto construída no começo do século XX para cobrir a Catedral Westminster, Londres, cuja espessura era de $0,91 \mathrm{~m}$ para um vão de $18,3 \mathrm{~m}$.

A primeira cúpula em concreto armado, projetada pelo engenheiro Walter Bauersfeld, foi construída em 1922 em Jena, tornando-se a primeira estrutura utilizando armadura em aço na história da engenharia civil. Esta cúpula, por ter um vão livre de 25,0 m com apenas $60,3 \mathrm{~mm}$ de espessura, foi um sucesso imediato e marcou um grande avanço na história da engenharia estrutural.

O grande entusiasmo inicial dos projetistas começou a decrescer uma vez que as cascas de concreto não eram tão viáveis economicamente como se imaginava; nesta mesma época, as vantagens do aço e ligas de alumínio começaram a surgir, com um grande avanço no último quarto do século $\mathrm{XX}$, que tem sido marcado pelo extensivo uso de cúpulas constituídas por elementos treliçados, confeccionados principalmente de aço.

As cúpulas continuam sendo de grande interesse para engenheiros e arquitetos pois, com elas, é possível conseguir um máximo de espaço com um mínimo de superfície de cobertura e com mínima interferência de apoios internos, além de serem muito econômicas no consumo dos materiais para a sua execução, quando comparadas com outros sistemas estruturais. 


\section{2- Desenvolvimento dos tipos de cúpulas}

Em função do grande interesse pelas cúpulas no século XIX, várias configurações estruturais foram desenvolvidas, principalmente na Alemanha, França e Suíça.

As primeiras cúpulas de ferro forjado, construídas no século XIX, eram formadas por meia tesouras treliçadas que possuíam o lado inferior reto e o superior curvo para pequenos vãos e ambos os lados curvos para cúpulas de grandes vãos produzindo, assim cúpulas nervuradas treliçadas.

As primeiras cúpulas possuíam forma hemisférica, gerando somente reações verticais nos apoios. A necessidade de reduzir a altura dessas estruturas tornou considerável os esforços horizontais nos apoios, obrigando os engenheiros a repensarem o uso deste sistema estrutural. Isto sem dúvida, contribuiu para o desenvolvimento de novas e melhores configurações para estas estruturas.

O grande interesse em cúpulas treliçadas e seu maior desenvolvimento ocorreu após a Segunda Guerra Mundial, influenciado pelas atividades do famoso projetista americano, Buckminster Fuller. Com sua cúpula Geodésica, ele novamente chamou a atenção de arquitetos e engenheiros para uma forma eficiente de construção. Todavia, muitos outros projetistas foram responsáveis pelo desenvolvimento de vários tipos de cúpulas treliçadas bem como a construção dessas estruturas em várias partes do mundo. Dentre eles podemos citar: Lederer, Kiewitt, Soare, Wright, du Château, Kadar, Tsuboi, Makowski e Matsushita. 


\section{3- Descrição dos tipos mais utilizados}

Segundo MAKOWSKI (1984), vários tipos de configurações de cúpulas treliçadas foram desenvolvidos mas apenas cinco tipos mostraram ser freqüentemente usados na prática. Uma descrição sucinta desses tipos pode ser vista a seguir.

\subsection{1- Cúpulas nervuradas}

As cúpulas nervuradas consistem de várias nervuras radiais com inércia elevada, interconectadas por vários anéis horizontais e reforçada por um anel na base.

Um exemplo de cúpula nervurada é a cobertura do Centro de Esportes Bell, Perth, Inglaterra que possui um diâmetro de $67 \mathrm{~m}$ e cobre uma área de $2973 \mathrm{~m}^{2}$. Esta estrutura é constituída por 36 nervuras, cada uma com $35 \mathrm{~m}$ de comprimento, unindo-se a um anel central. A figura 2.1 mostra o detalhe desta estrutura. 


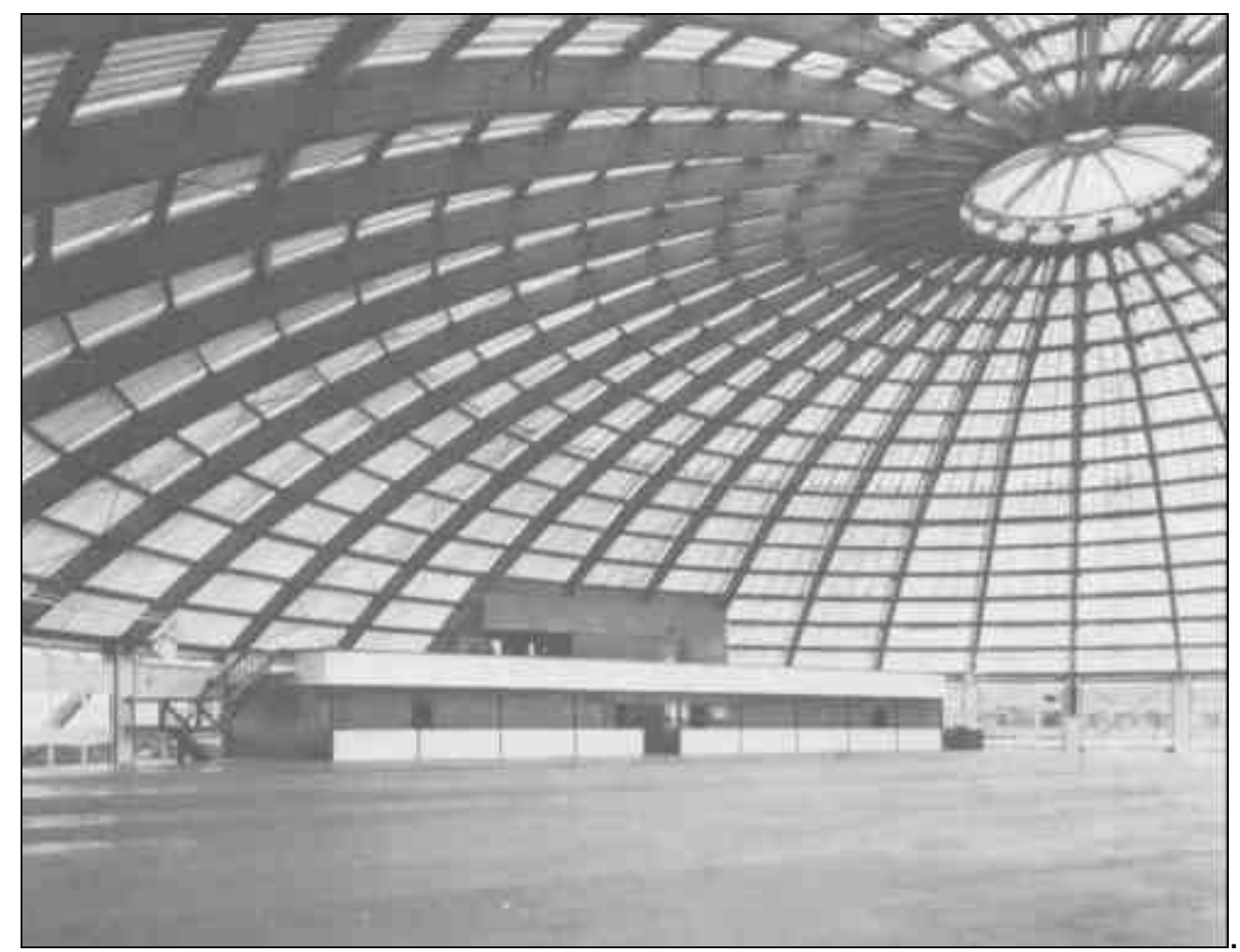

Figura $2.1^{1}$ - Exemplo de cúpula nervurada

\subsection{2- Cúpulas Schwedler}

A cúpula Schwedler, nome devido ao engenheiro alemão J.W. Schwedler, é constituída por anéis horizontais conectados a vários anéis radiais, ambos com inércia semelhantes. Para oferecer maior estabilidade à estrutura, cada trapézio formado pela interseção dos anéis é subdividido em dois triângulos pela introdução de um elemento na diagonal.

As nervuras radiais são elementos contínuos conectados rigidamente aos anéis horizontais permitindo que, além da força axial, os elementos fiquem sujeitos a flexão e torção.

A figura 2.2 mostra a construção de uma cúpula em aço do tipo Schwedler.

\footnotetext{
${ }^{1}$ MAKOWSKI (1984)
} 


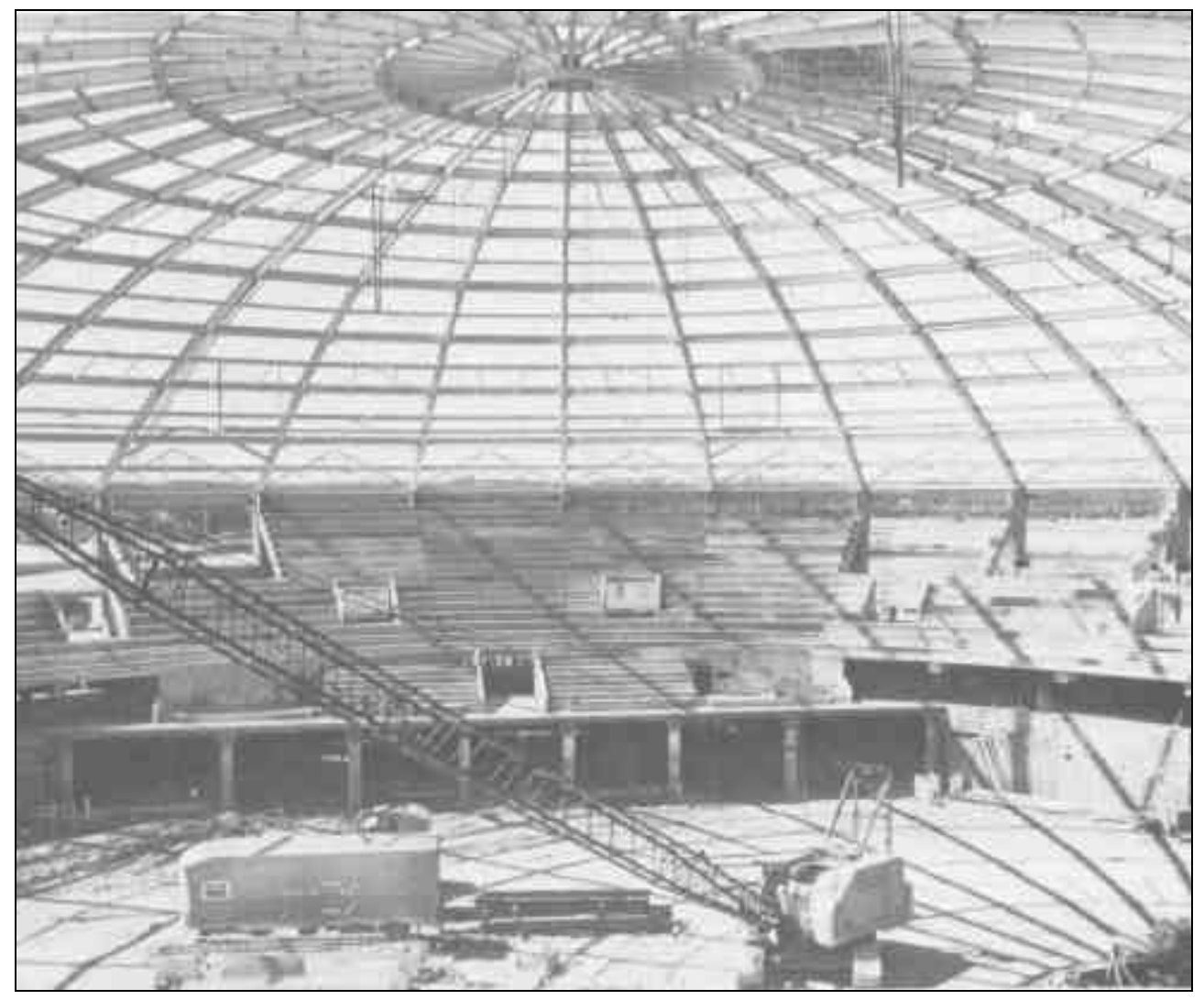

Figura $2.2^{1}$ - Exemplo de cúpula Schwedler

2.3.3- Cúpulas com malha "three-way"2

Este tipo de cúpula é composto por tubos agrupados em três direções formando uma malha com espaçamento triangular onde a conexão entre as três camadas de tubos é feita por meio de dois grampos em forma de "U", localizados acima e abaixo dos tubos, fixados por parafusos; recomenda-se ainda que, no mínimo, um terço dessas conexões sejam unidas por soldas.

Como exemplo pode-se citar a cúpula em Brno, Czechoslovakia, que possui um vão livre de $93,5 \mathrm{~m}$ sendo formada por anéis tubulares horizontais interconectados com diagonais curvas localizados uns sobre os outros. A figura 2.3 apresenta a montagem dessa estrutura.

\footnotetext{
${ }^{1}$ MAKOWSKI (1984)

2 malha "three-way": malha formada por tubos agrupados em três direções formando uma malha com espaçamento triangular
} 


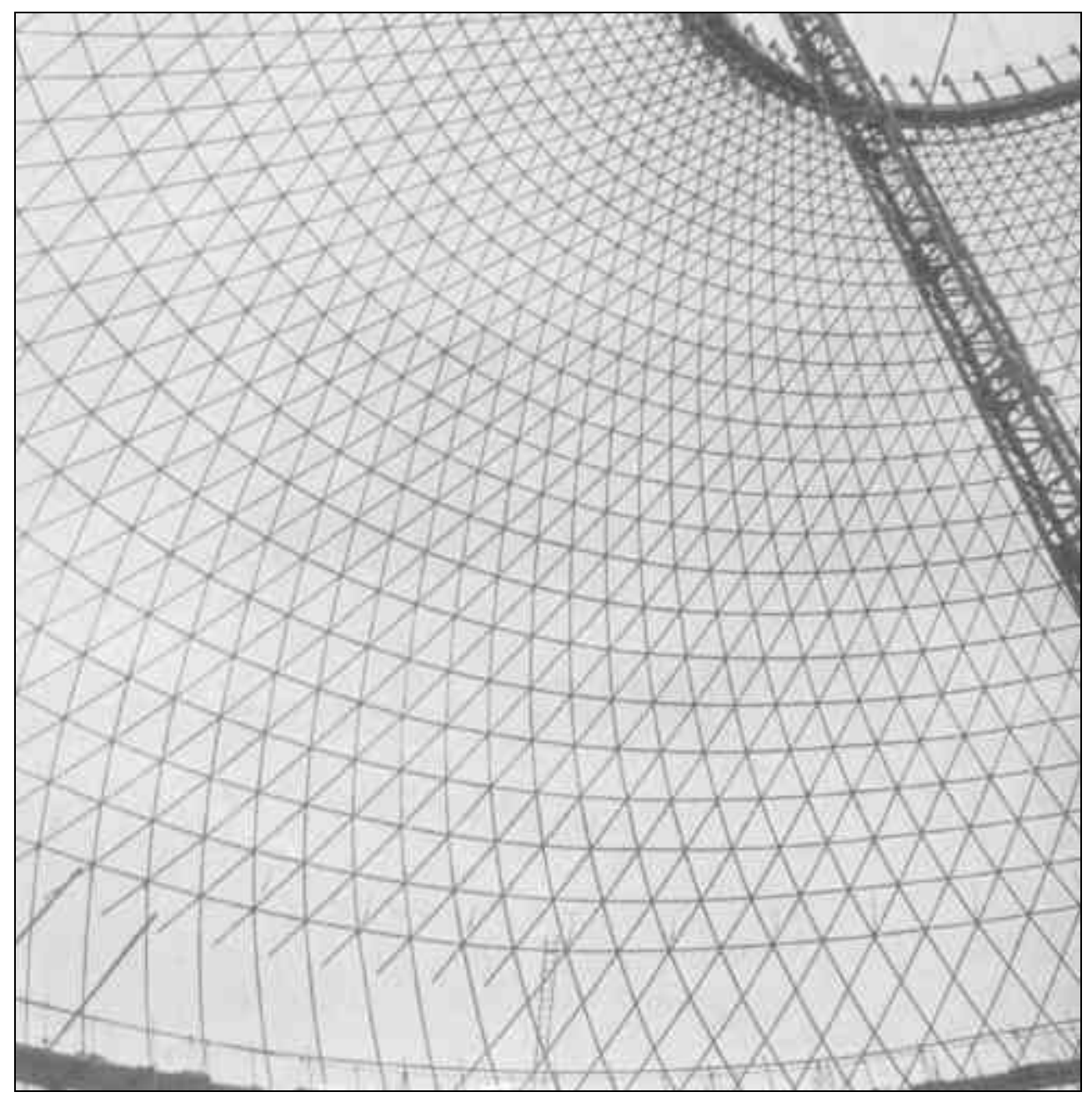

Figura $2.3^{1}$ - Exemplo de cúpula com malha "three-way"

\subsection{4- Cúpulas lamelares}

As cúpulas lamelares consistem de várias unidades similares, chamadas lamelas, arranjadas em um formato de losango onde as terças usadas para apoiar a cobertura, ou a própria cobertura, completam a estabilidade do conjunto.

Segundo MAKOWSKI (1984), a grande popularidade das cúpulas lamelares deve-se ao excelente comportamento dessas estruturas sob ação de ventos, existindo exemplo dessas estruturas que permaneceram sem

\footnotetext{
${ }^{1}$ MAKOWSKI (1984)
} 
dano após vento com velocidade superior a $200 \mathrm{Km} / \mathrm{h}$ em Miami, Estados Unidos.

A figura 2.4 apresenta uma cúpula em aço constituídas por lamelas treliçadas.

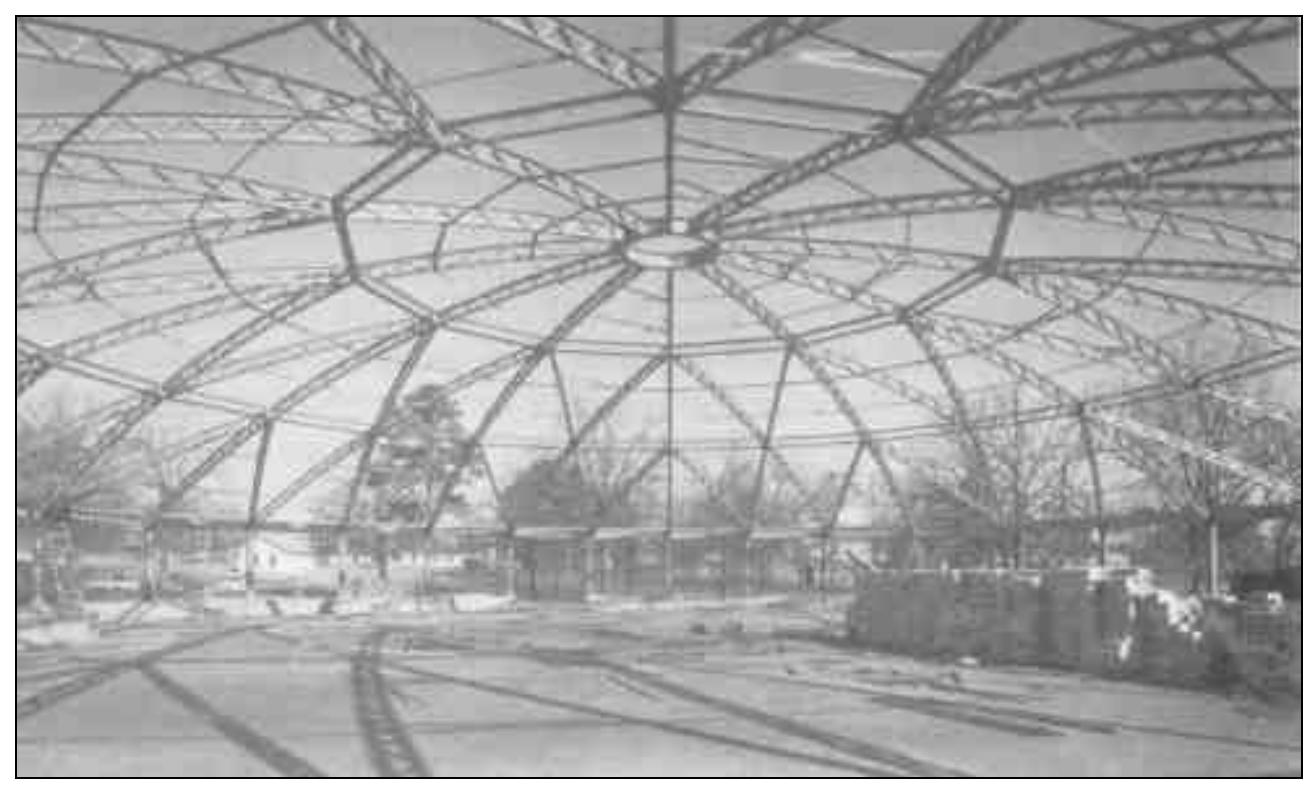

Figura $2.4^{1}$ - Exemplo de cúpula constituída por lamelas

\subsection{5- Cúpulas geodésicas}

De acordo com MAKOWSKI (1984), Richard Buckminster Fuller, o inventor das cúpulas geodésicas, sem possuir qualificação formal em arquitetura e engenharia, declarou que sua estrutura poderia ser usada para ilhas submersas, servindo como bases para submarinos, perfuração de poços de petróleo ou inspeções oceanografias. Ele prognosticou também total controle climático, incluindo cidades inteiras, por meio de grandes cúpulas geodésicas.

\footnotetext{
${ }^{1}$ MAKOWSKI (1984)
} 
Em 1959, Buckminister Fuller propôs uma cúpula de 3,22 Km de diâmetro cobrindo parte da cidade de New York da rua 23th a 59th, alegando que as economias para a cidade em itens como condicionamento de ar, ruas limpas, remoção de neve e horas de trabalho perdidas resultante do frio, poderia logo repor o investimento inicial. De acordo com sua análise, esta cúpula teria o peso avaliado em torno de 80.000 toneladas e poderia ser montada em seções de cinco toneladas com auxílio de helicópteros em um período de três meses.

Muitos engenheiros estruturais observaram descrentemente aquelas predições levando o Dr. G. R. Kiewitt, um dos mais experientes projetistas de cúpulas treliçadas, responsável pela construção de duas enormes cúpulas em aço no mundo, uma em Houston com vão livre de 200 m, e outra em New Orleans, vão livre de 213 m, declarar em 1962, que o diâmetro máximo de uma cúpula de aço de dupla camada que poderia ser teoricamente construída naquele tempo não excederia $427 \mathrm{~m}$.

As cúpulas geodésicas desenvolvidas por Buckminster Fuller permitem facilidades para serem pré-fabricadas, uma vez que a variação do comprimento de seus elementos é pequena, fato que torna esta estrutura largamente utilizada. A figura 2.5 ilustra um exemplo de uma cúpula geodésica. 


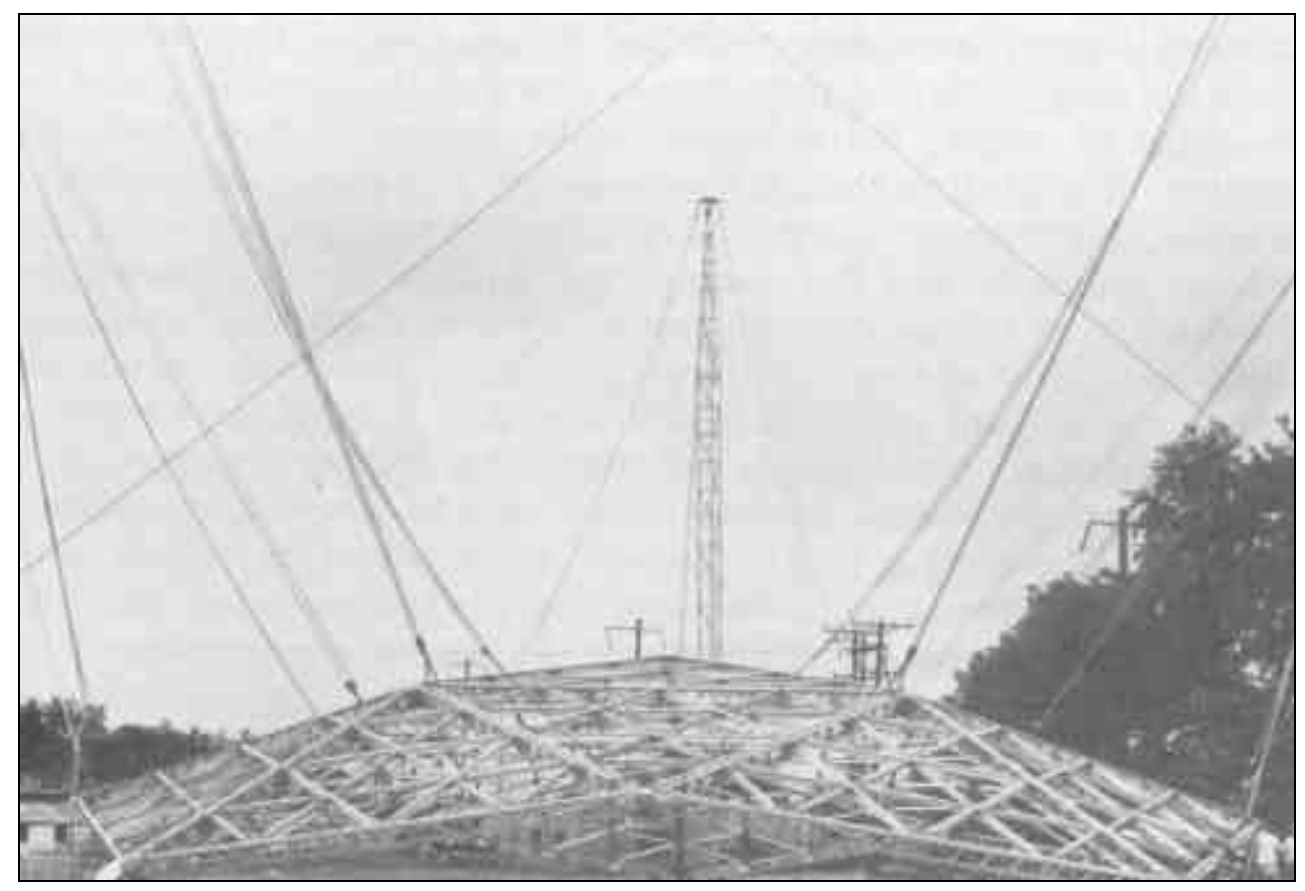

Figura $2.5^{1}$ - Exemplo de cúpula geodésica

\section{4- Cúpulas mais utilizadas no Brasil}

Apesar de existirem vários tipos de configurações de cúpulas treliçadas, o tipo predominantemente utilizado no Brasil é o constituído por elementos tubulares na qual a extremidade das barras são estampadas e conectadas por um único parafuso (detalhe denominado típico, na EESCUSP) ou utilizando chapas de aço conectadas as barras estampadas com parafusos.

Estes elementos tubulares, na maioria das cúpulas, são dispostos de maneira a formar uma malha que para estruturas espaciais planas é denominada quadrada sobre quadrada ou retangular sobre retangular, com a diferença de possuírem, nas cúpulas, os banzos superiores e inferiores curvos. A figura 2.6 ilustra estes tipos de malha.

\footnotetext{
${ }^{1}$ MAKOWSKI (1984)
} 

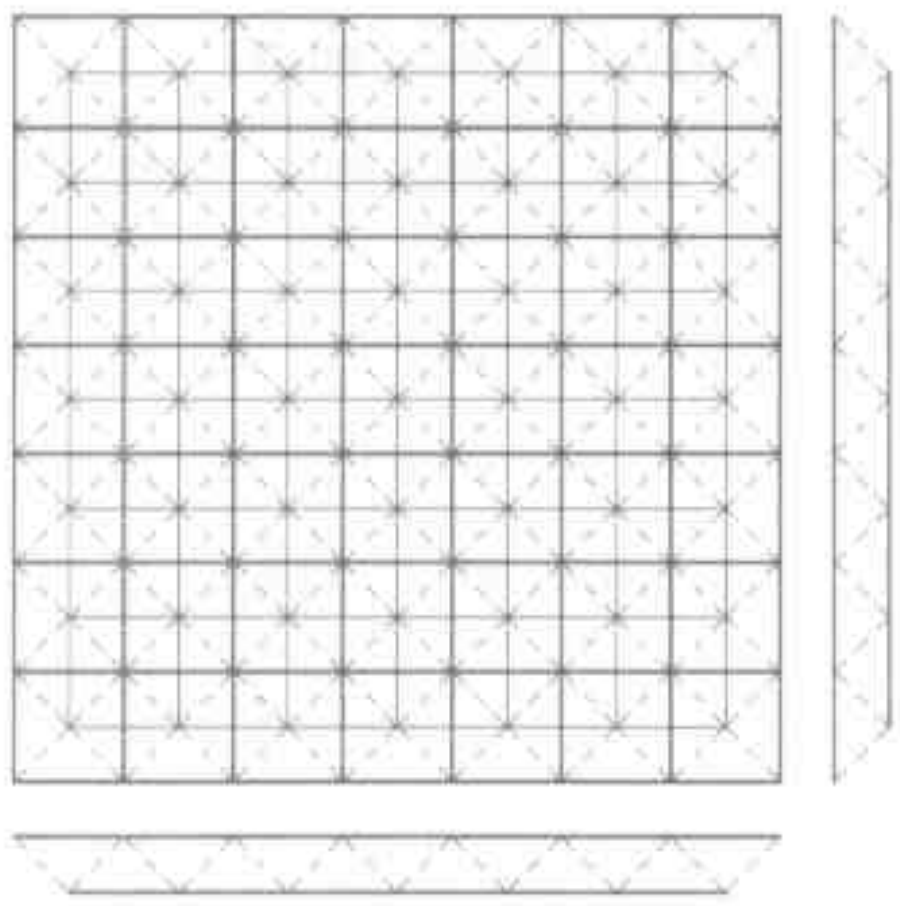

Figura 2.6a - Quadrada sobre quadrada

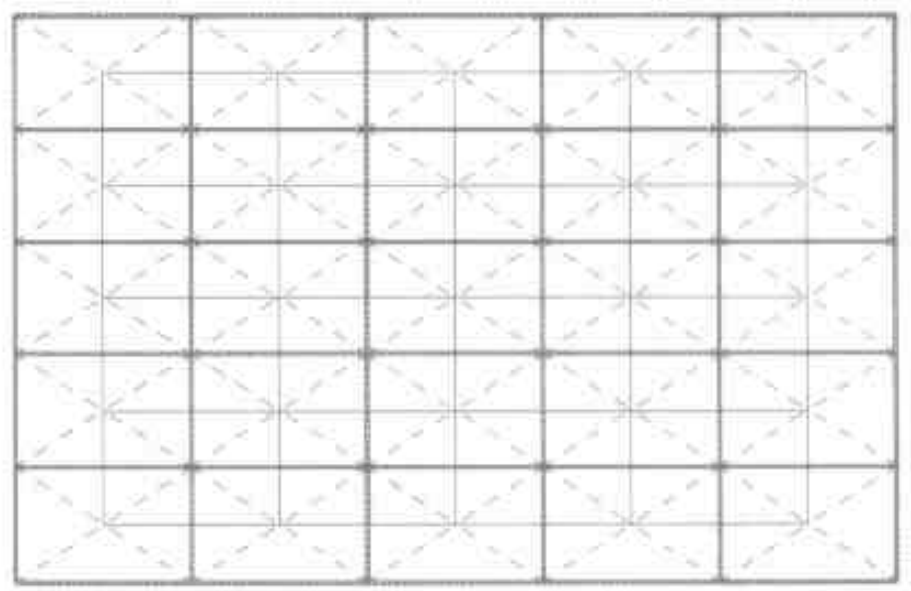

Figura 2.6b - Retangular sobre retangular

Figura $2.6^{1}$-Malha utilizada em cúpulas compostas por elementos tubulares

O inconveniente neste tipo de configuração adotada no Brasil, está no sistema de ligação empregado. Alguns desses problemas decorrem das

\footnotetext{
${ }^{1}$ MAGALHÃES (1996)
} 
excentricidades existentes nas ligações e da variação de inércia nas extremidades devido ao amassamento da barra para confecção do nó típico.

Este sistema de ligação, que será discutido em capítulos posteriores, não é bem caracterizado experimentalmente, e não reproduz as hipóteses adotadas pelos calculistas nas análises numéricas, o que pode acarretar problemas estruturais. A figura 2.7 ilustra este tipo de nó utilizado no Brasil, salientando que este detalhe não tem paralelo no mundo.

A figura 2.8 apresenta um exemplo da cúpula, na fase de montagem, utilizadas no Brasil com sistema de ligação típico.

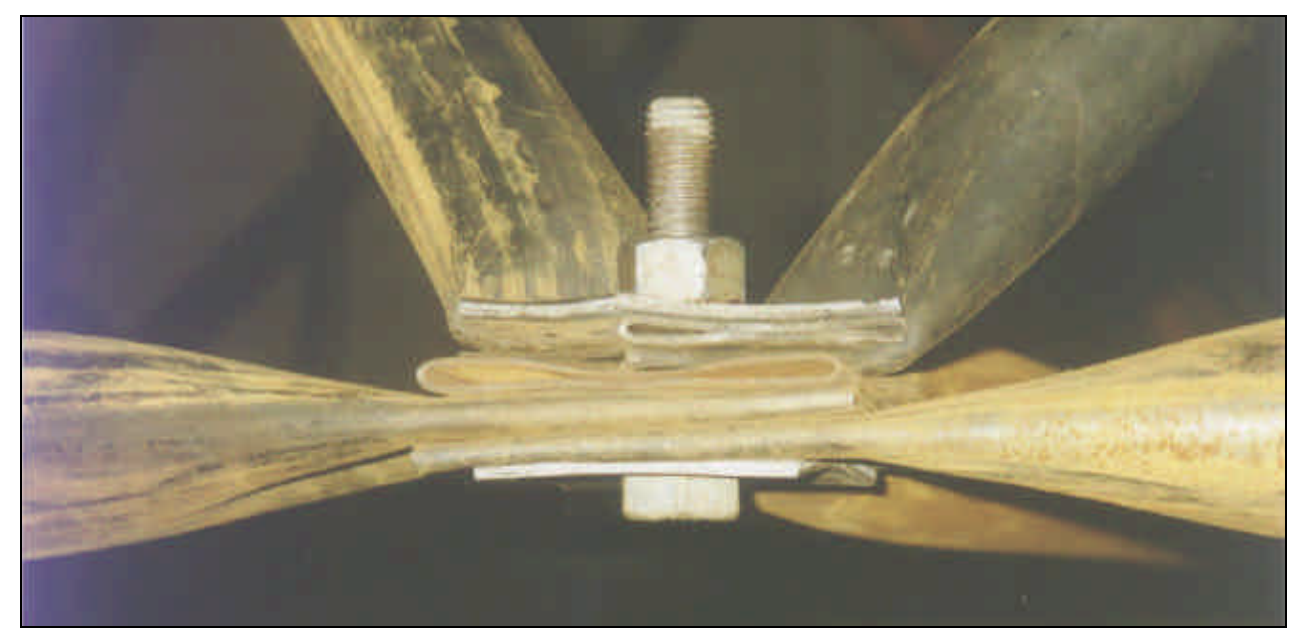

Figura 2.7 - Detalhe do nó típico

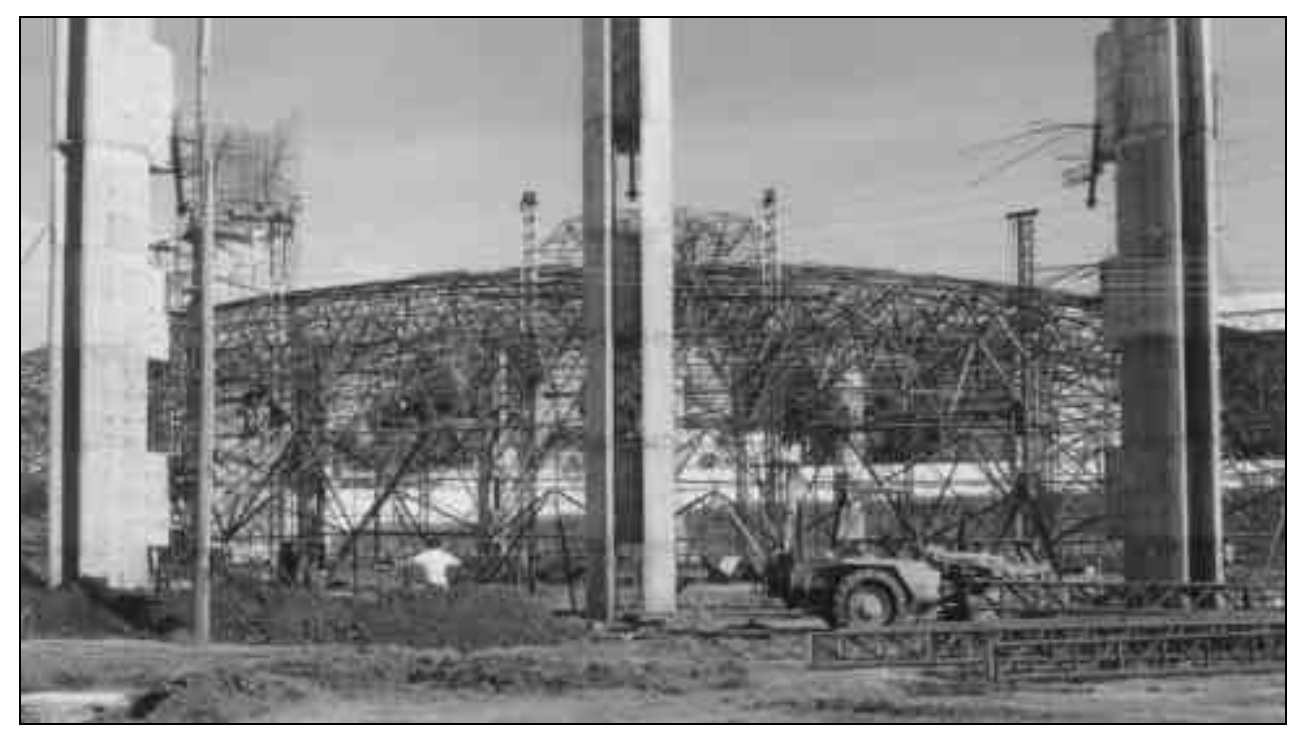

Figura 2.8 - Exemplo de cúpula utilizada no Brasil 
Existem também outros tipos de ligações melhor estudadas e que reproduzem as hipóteses correntes para o cálculo estático, normalmente realizado supondo as hipóteses de treliças espaciais.

Entre estes podemos citar: VESTRUT, OKTAPLANTTE, TRIODETIC, NODUS, PALC, ECO, MERO e muitos outros.

\section{5- Comportamento de cúpulas treliçadas}

Segundo MULLORD (1984), uma cúpula em casca resiste à ação de carregamentos gravitacionais com um sistema de forças agindo sobre sua superfície sendo, tipicamente, uma força principal de compressão agindo verticalmente na superfície da cúpula e uma força horizontal menor, geralmente de tração, agindo em torno da cúpula, como mostra a figura 2.9.

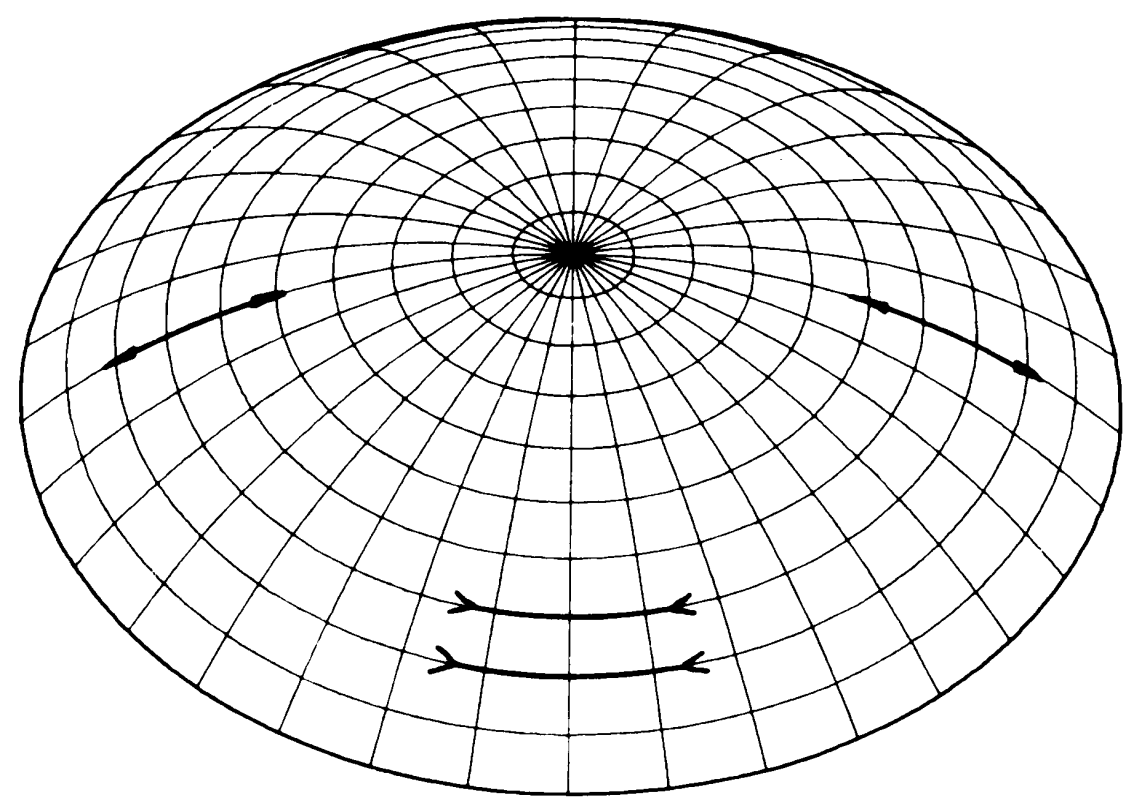

Figura $2.9^{1}$ - Sistema de forças agindo sobre a cúpula em casca

\footnotetext{
${ }^{1}$ MAKOWSKI (1984)
} 
O comportamento de uma cúpula treliçada, no entanto, depende da configuração da malha que a constitui. As cúpulas treliçadas que são totalmente trianguladas, como mostra a figura $2.10 \mathrm{a}$, possuem elevada rigidez em todas as direções de sua superfície, produzindo esforços principalmente axiais com direção e magnitude similar daqueles obtidos para uma cúpula em casca.

Uma cúpula que não é completamente triangulada, como a da figura $2.10 \mathrm{~b}$, necessita que seus elementos sejam conectados rigidamente uns aos outros possibilitando que, além da força axial, os mesmos fiquem sujeitos a flexão e torção para garantir a estabilidade requerida para a estrutura. Já a cúpula apresentada na figura 2.10c necessitará de nós rígidos $^{1}$ ou cobrimento estrutural para se tornar estável e resistir carregamentos assimétricos.

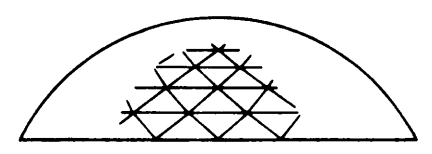

(a)

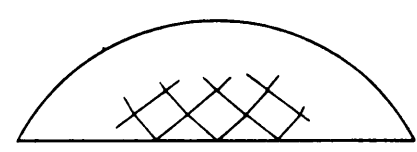

(b)

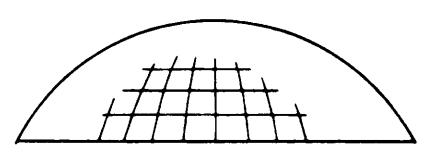

(c)

Figura $2.10^{2}$ - Configuração de cúpulas treliçadas

Sabe-se que a maior parte dos fabricantes e montadores que têm experiência na construção de cúpulas de aço estão convencidos que estas estruturas tem uma reserva de resistência maior do que os cálculos indicam, devido à ação da cobertura como casca ou membrana que é desprezada na análise normalmente empregada para o seu dimensionamento, ou seja, treliças espaciais.

\footnotetext{
${ }^{1}$ Nó rígido: nó com restrição a rotação

${ }^{2}$ MAKOWSKI (1984)
} 


\section{6- Análise estática}

Segundo MULLORD (1984), para que uma estrutura possa ser analisada, a mesma deve ser representada por uma idealização matemática que a aproxime ao máximo do comportamento real da estrutura.

$\mathrm{Na}$ análise de cúpulas, freqüentemente adota-se uma idealização como treliça espacial, nós rotulados, ou como pórtico, onde os nós são considerados rígidos. Para muitas cúpulas treliçadas uma idealização como treliça espacial é suficiente. No entanto, em estruturas que os momentos fletores são significativos em seus elementos, como em cúpulas com malha não trianguladas e com elementos curvos contínuos, uma idealização como pórtico espacial é necessária.

Definida a idealização a ser utilizada no modelo deve-se optar pelo tipo de análise a ser feita, isto é, uma análise linear ou não linear.

Se os deslocamentos relativos dos nós de uma cúpula são pequenos, uma análise linear fornecerá resultados satisfatórios. No entanto, se houver uma mudança significativa na geometria da estrutura o projetista deve optar por uma análise não-linear, onde o carregamento é aplicado em pequenos incrementos e a cada incremento, a rigidez da estrutura é corrigida para considerar mudanças no comportamento dos elementos (não-linearidade física) e na geometria da estrutura (não-linearidade geométrica). 


\section{7- Alguns aspectos do projeto e execução}

\subsection{1- Escolha da configuração adequada}

Segundo MAKOWSKI (1984), para se obter uma cúpula treliçada com o mínimo custo possível, o projeto deve incluir em sua otimização: custos dos nós, tipo de material de cobertura e técnicas de fabricação e montagem, o que torna esta tarefa extremamente difícil.

Atualmente o projeto final de importantes cúpulas para grandes vãos é resultado de extensivos estudos de diferentes tipos de malhas comparados entre si, avaliando as vantagens e desvantagens de cada solução.

\subsection{2- Ações de projeto}

O peso próprio das cúpulas depende principalmente do seu vão, da configuração da malha utilizada, do tipo de material de cobertura e, naturalmente, do material que compõe a estrutura.

Segundo WALKER (1984), na análise de cúpulas o efeito de qualquer carregamento concentrado deve ser considerado, uma vez que este tipo de ação tem influência considerável sobre a deformabilidade da estrutura.

Outro efeito indispensável para análise deste tipo de estrutura é o carregamento assimétrico, provocado pelo vento. Portanto, para se avaliar analiticamente a distribuição de pressão do vento sobre a superfície dômica, deve-se ter muita cautela, recorrendo a testes em túnel de vento, caso se tenha alguma dúvida.

Os resultados de pesquisas produzidos por Maher $(1965,1966)$ e Blessman (1971) indicam que é muito difícil obter as condições necessárias em túnel de vento que representem o comportamento da estrutura, tendo em vista as dificuldades inerentes à escala dos protótipos e a devida 
simulação do perfil de velocidade para as condições em que a estrutura está submetida. Mesmo assim, são indispensáveis para se avaliar a distribuição de pressão do vento sobre a cúpula.

\subsection{3- Fabricação}

A fabricação de uma cúpula, assim como a de uma estrutura espacial qualquer, necessita de alta precisão de fabricação dos elementos que a constitui pois, em caso contrário, os erros podem acumular-se durante a montagem ocasionando problemas para unir os elementos finais.

\subsection{4- Acabamento e Pintura}

Para o acabamento de uma cúpula pode-se utilizar a pintura por imersão, a galvanização e a pintura eletrostática, sendo que estes três métodos permitem a automatização de todo o processo de pintura, resultando numa produtividade maior.

Para proteger a estrutura da corrosão pode-se utilizar a galvanização ou a pintura eletrostática, sendo que a primeira oferece proteção externa e interna às barras enquanto que a segunda oferece apenas proteção à superfície externa.

A galvanização, no entanto, resulta em uma cor acinzentada necessitando de uma demão de tinta para melhorar o aspecto visual da estrutura, caso esta não seja a cor desejada. Já a pintura eletrostática, a base de epóxi, possibilita várias cores oferecendo boa proteção externa por barreira já que a tinta não contém solventes e a película resultante é praticamente isenta de porosidade, mas tem como desvantagem a necessidade de utilizar aço de alta resistência à corrosão atmosférica ( ARCOR) para proteção interna do tubo. 


\subsection{5- Montagem}

$\mathrm{Na}$ montagem de uma cúpula, três métodos são freqüentemente utilizados:

a) Montagem por elemento

Neste método, os elementos que constituem a malha estrutural são montados diretamente em sua posição definitiva. Uma vez que a montagem é feita elemento por elemento, grandes vãos podem ser construídos usando equipamentos de içamento relativamente simples como conjunto de roldanas e polias. No entanto, com o aumento de altura em que a montagem é executada, o custo com andaimes aumenta e surge o problema da segurança dos trabalhadores, o que exige a devida análise dos custos finais de montagem. A figura 2.11 apresenta um detalhe deste método de montagem. 


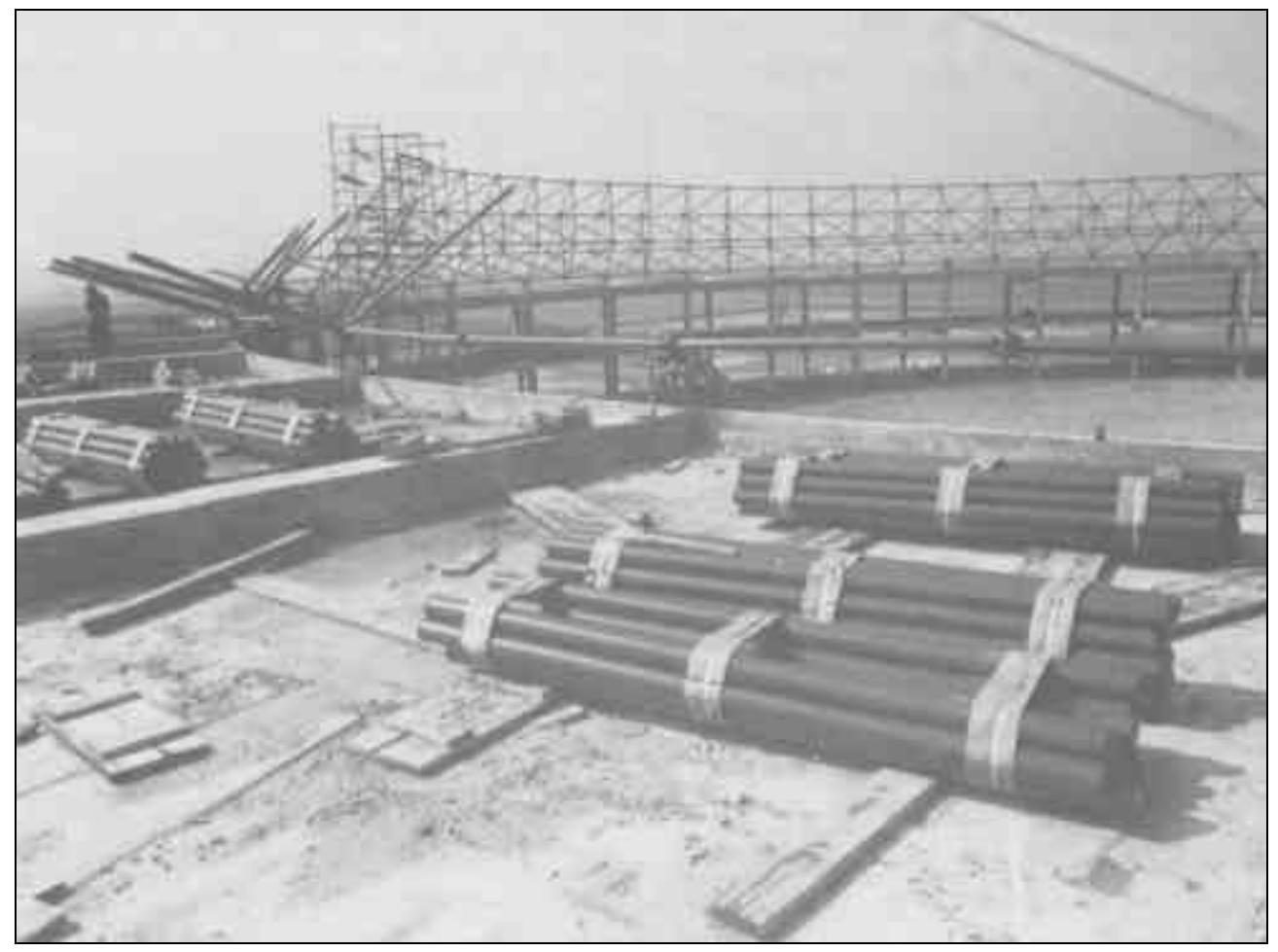

Figura $2.11^{1}$ - Montagem por elemento

b) Montagem por conjuntos parciais

Neste método, partes da estrutura são montadas no chão e depois, com o auxílio de equipamentos de içamento, são unidas ao resto da estrutura minimizando o volume de montagem em altura elevada. $O$ mérito deste método é que o volume de trabalho no solo é aumentado facilitando assim seu controle e eficiência. A figura 2.12 apresenta um exemplo desta técnica de montagem.

\footnotetext{
${ }^{1}$ MAKOWSKI (1984)
} 


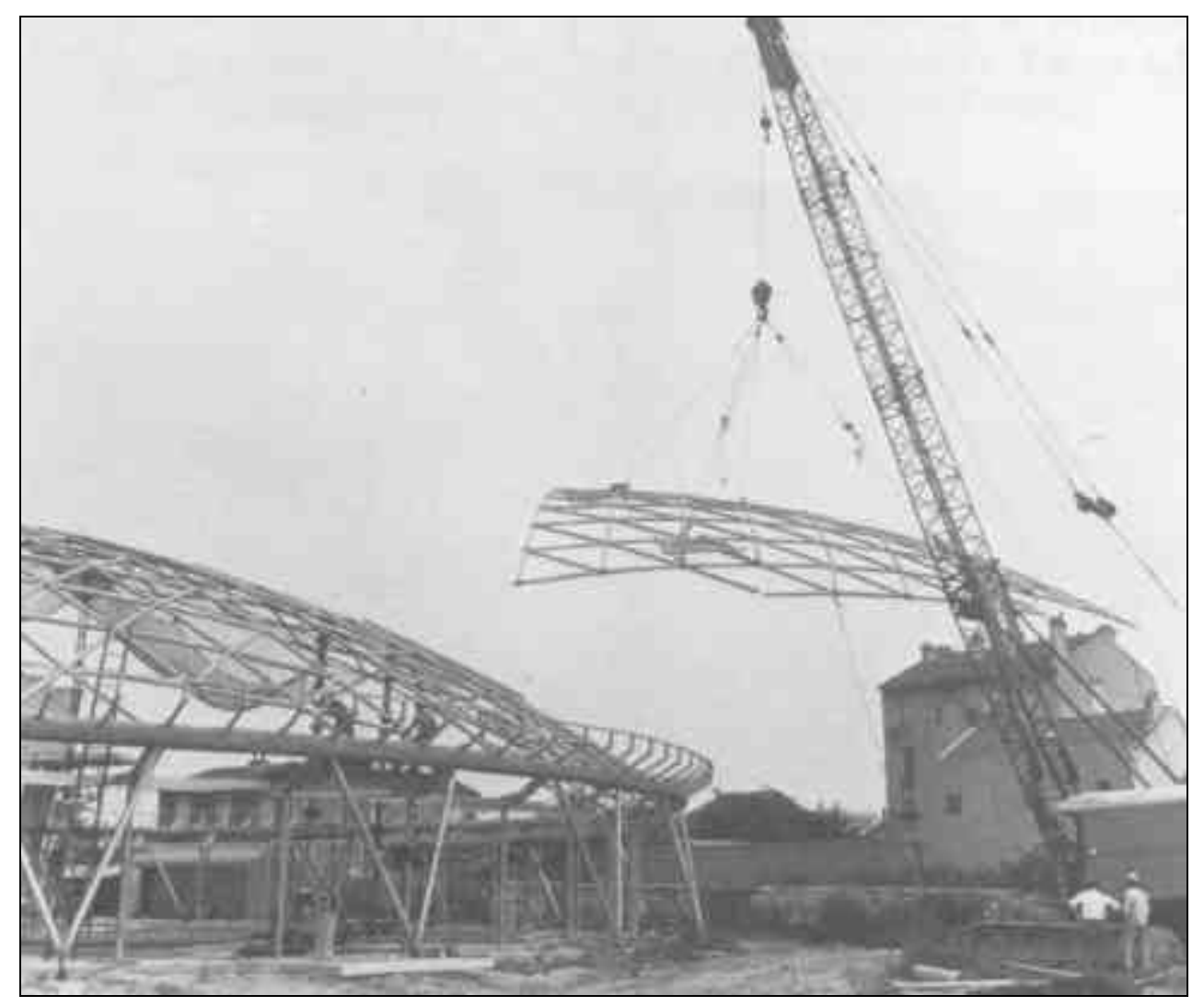

Figura $2.12^{1}$ - Montagem por conjuntos parciais

c) Montagem por içamento

Para grandes estruturas, onde a montagem por elemento ou conjuntos parciais não é adequada, utiliza-se a montagem por içamento, em que a estrutura é inteiramente montada no chão e depois, com auxílio de equipamentos como guindastes, colocada em sua posição definitiva. Ressalta-se que esta técnica requer especial atenção durante o içamento da estrutura para que não sejam introduzidos esforços para os quais as estruturas não foram projetadas.

A figura 2.13 apresenta um exemplo desta técnica de montagem. 


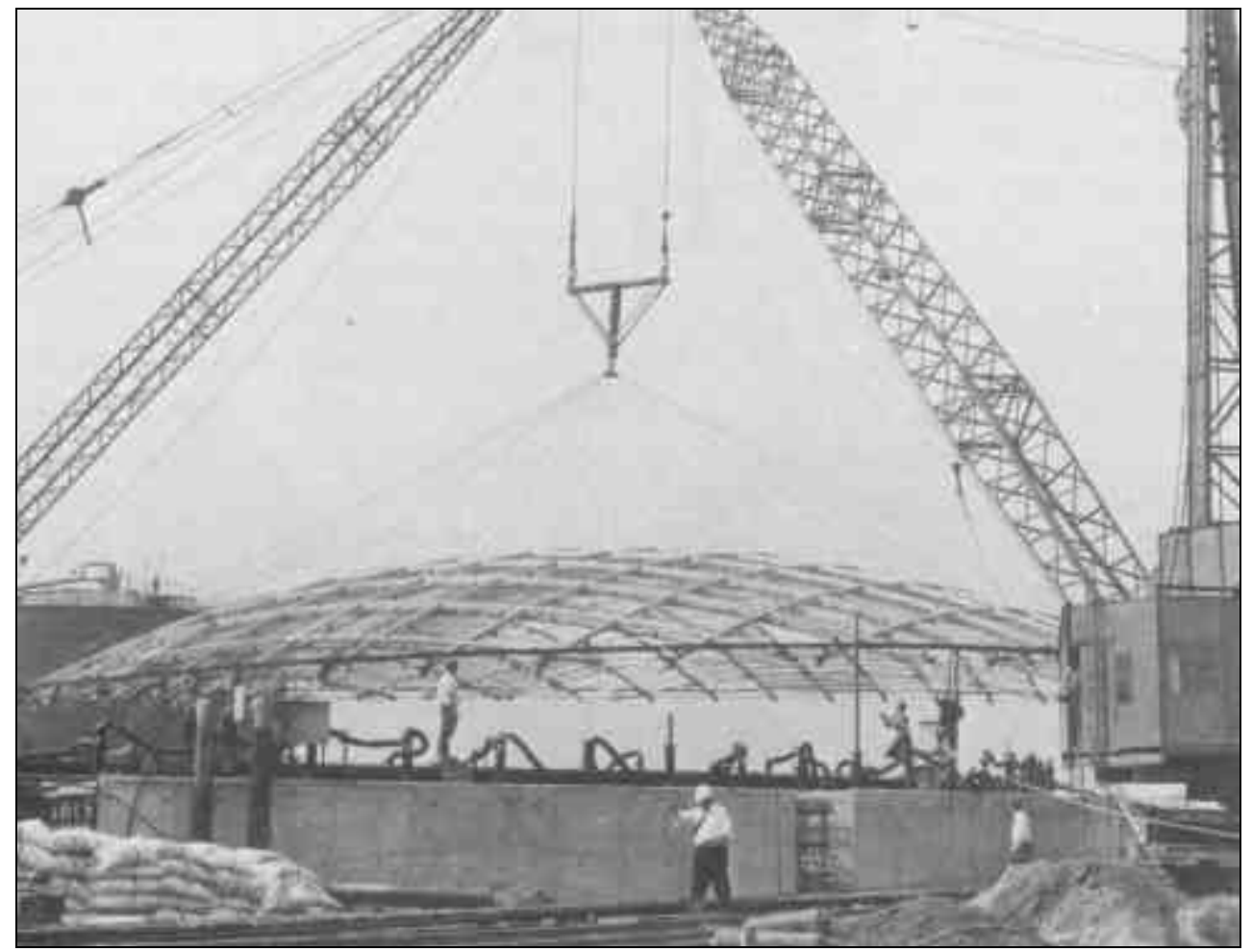

Figura $2.13^{1}-$ Montagem por içamento

Cada técnica de montagem apresenta vantagens e desvantagens sobre as outras, em função das condições gerais da estrutura.

Para que se possa fazer uma seleção entre os métodos de montagem para uma determinada estrutura é importante considerar os seguintes fatores:

- condições de projeto: tipo e dimensões da estrutura;

- condições para montagem: disponibilidade de espaço no local, tipos de equipamentos de içamento disponíveis, transporte, tempo de trabalho, custo e relação com outros trabalhos;

- condições de segurança: segurança do operário, condições climáticas durante a montagem.

Usualmente, estas condições são analisadas e então um plano detalhado de montagem é feito para o método mais apropriado.

\footnotetext{
${ }^{1}$ MAKOWSKI (1984)
} 
Baseado no exposto deste capítulo pode-se afirmar que as cúpulas destinam-se a grandes vãos exigindo dos calculistas uma análise particular para cada obra, não sendo possível estabelecer parâmetros gerais e recomendações em função destas particularidades.

O principal fator no projeto constitui-se nos tipos de nós possíveis de serem utilizados, determinando assim os fatores econômicos e estruturais, no projeto de cúpulas. No capítulo seguinte aborda-se os nós para este tipo de estrutura e em particular os nós mais utilizados no Brasil. 


\section{Sistemas de ligação}

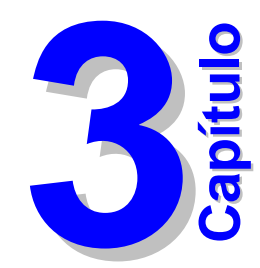

Em estruturas espaciais com elementos de aço, em particular as cúpulas, o tipo de ligação a ser utilizado depende, sobretudo, da seção transversal dos elementos que as constituem, da disposição dos elementos na estrutura e da geometria da própria estrutura. Também deve-se considerar os efeitos referentes as facilidades de montagem e o custo, já que as ligações têm influência significativa no custo final da estrutura.

No Brasil, as estruturas espaciais planas ${ }^{1}$ ou de superfície curvas, como é o caso das cúpulas, em sua grande maioria são formadas por elementos tubulares de seção circular em aço ou alumínio.

Para obtenção dos esforços solicitantes nos elementos que compõem a estrutura, admite-se, na maioria das vezes, a hipótese de nós rotulados, quando o sistema de malhas empregado o permite (malhas triangulares); porém a rigidez do nó influencia no comportamento global da estrutura, podendo alterá-lo significativamente.

\footnotetext{
${ }^{1}$ estruturas espaciais planas: usualmente utilizada para definir estruturas metálicas de cobertura formadas por duas camadas paralelas de barras (banzos) ligadas entre si por outras barras (diagonais), não caracterizando um plano principal para as barras que compõe a estrutura resistente.
} 
Neste capítulo serão apresentados vários sistemas de ligações utilizados em todo o mundo para cúpulas e estruturas espaciais planas constituídas por elementos de seção transversal circular. Já as ligações utilizadas em nosso país serão discutidas e analisadas mais detalhadamente.

\section{1- Apresentação de vários sistemas de ligação}

Em se tratando de estruturas formadas por elementos de seção transversal circular, a maioria dos sistemas de ligação utilizados em estruturas espaciais planas são também utilizados em cúpulas. Alguns desses sistemas são patenteados, portanto bem caracterizados experimentalmente, outros, no entanto, são sistemas geralmente empíricos, projetados com poucos estudos que confirmem seu comportamento, ou baseados em hipóteses simplistas.

A maioria desses sistemas possuem ligações parafusadas, uma vez que as ligações soldadas, além de um custo elevado, apresentam maiores dificuldades construtivas, sendo praticamente inviável economicamente.

A figura 3.1 apresenta uma estrutura constituída de barras de seção circular sendo soldada; as condições de trabalho do soldador indicam a dificuldade de sua execução e, como conseqüência, a precariedade na qualidade da solda executada.

Com o exposto acima é possível concluir que a solução de estruturas espaciais soldadas não é recomendável quer sob o ponto de vista econômico, quer sob o ponto de vista da segurança obtida. 


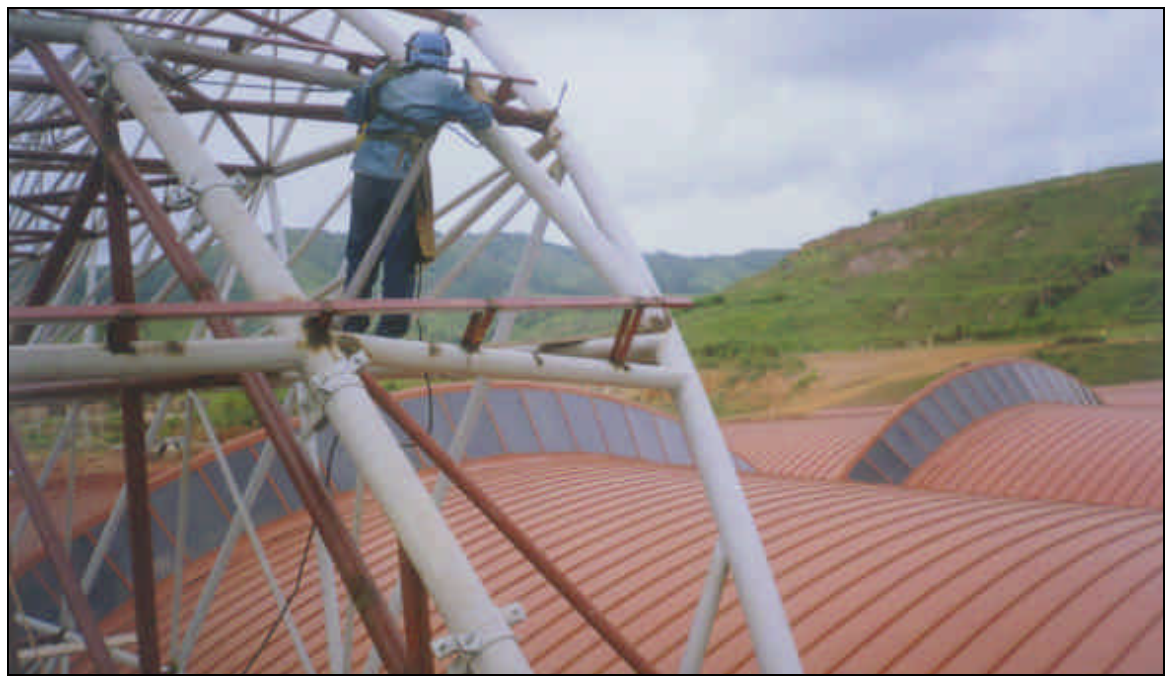

Figura 3.1 - Detalhe do nó com ligação soldada

A seguir estão ilustrados vários sistemas de ligação utilizados em estruturas espaciais planas e curvas formadas por elementos de seção transversal circular.

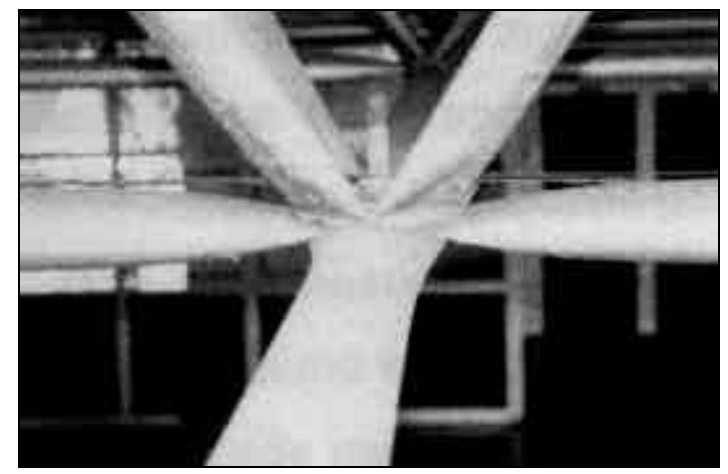

Sistema TÍPICO (Brasileiro)

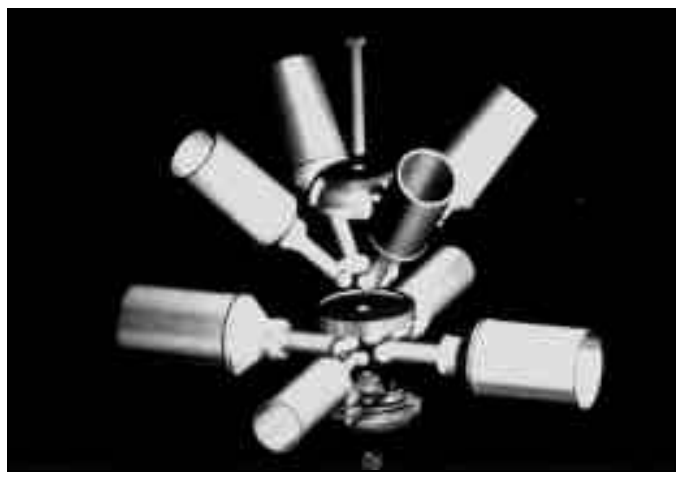

Sistema VESTRUT

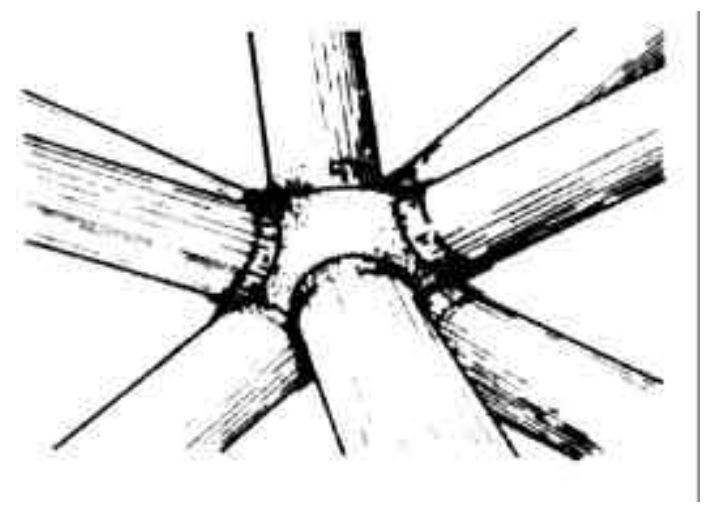

Sistema OKTAPLANTTE

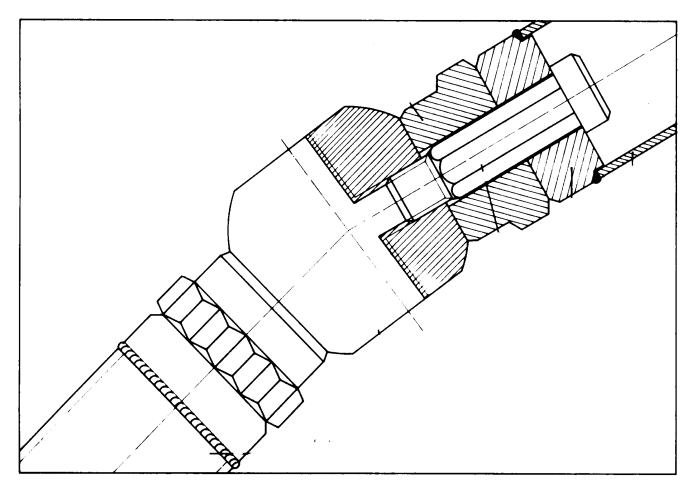

Sistema MERO (Alemão) 


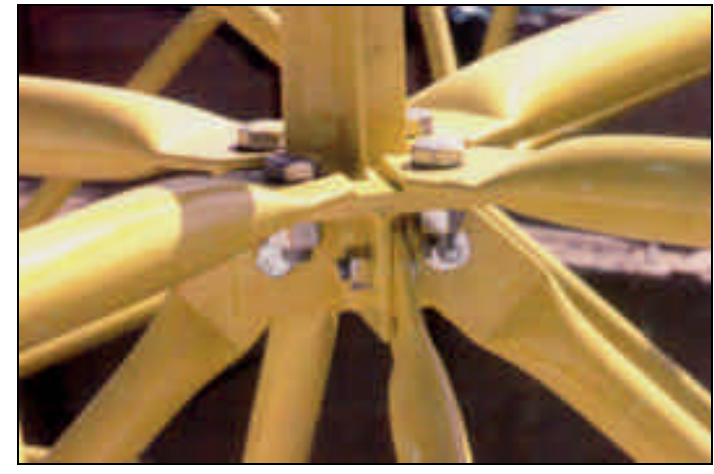

Sistema Italiano

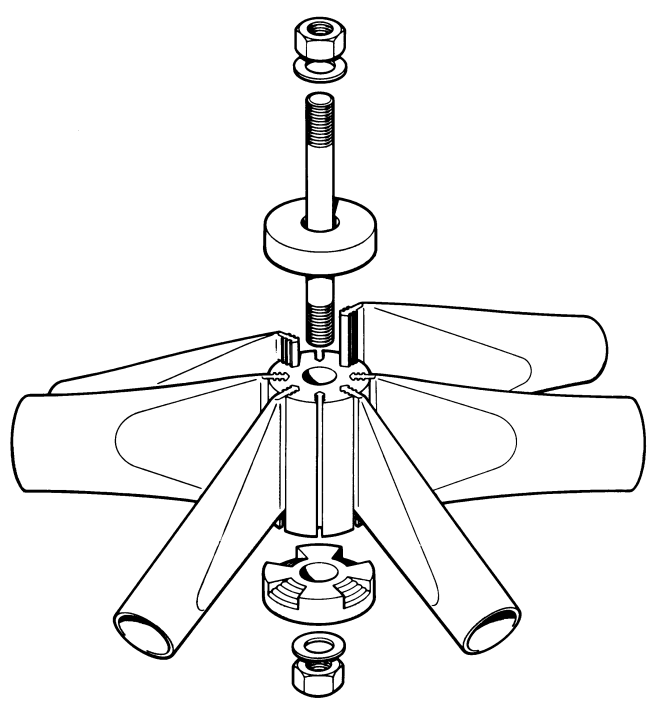

Sistema TRIODETIC (Canadense)

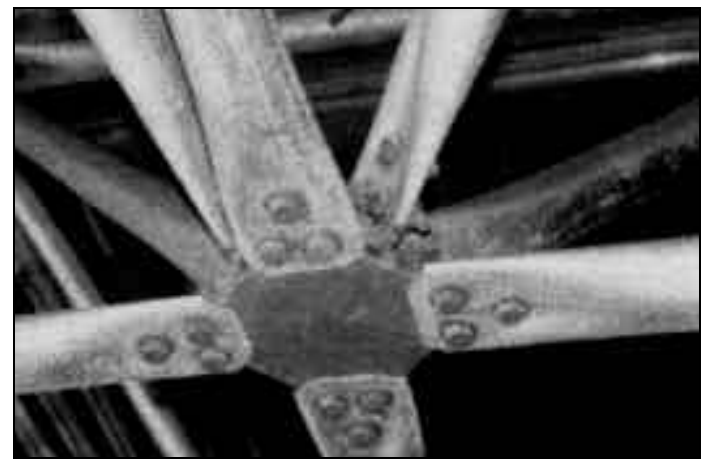

Sistema com nó de aço (Brasileiro)

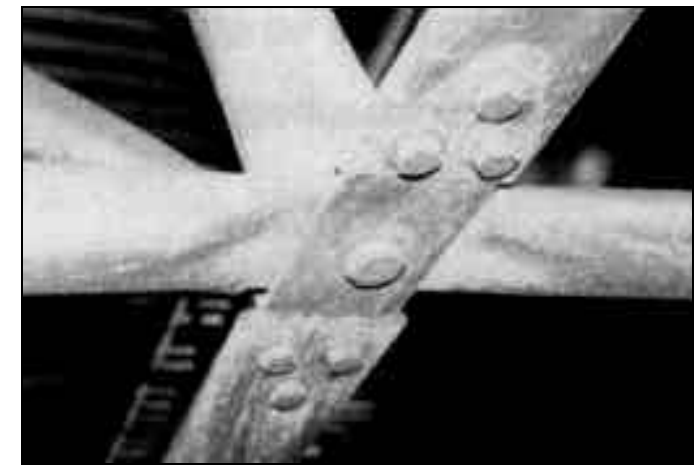

Sistema típico com chapa complementar (Brasileiro)

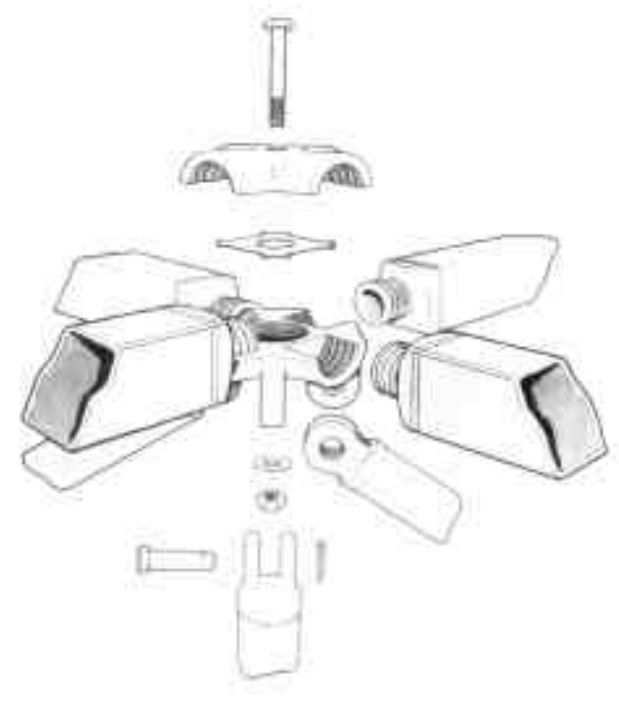

Sistema NODUS

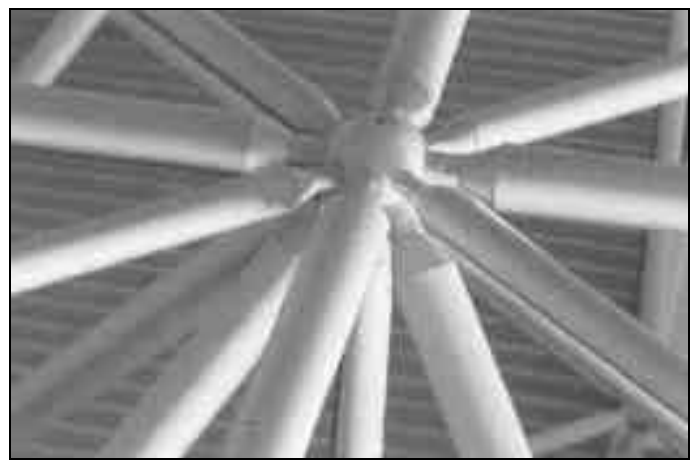

Sistema PALC (Espanhol) 


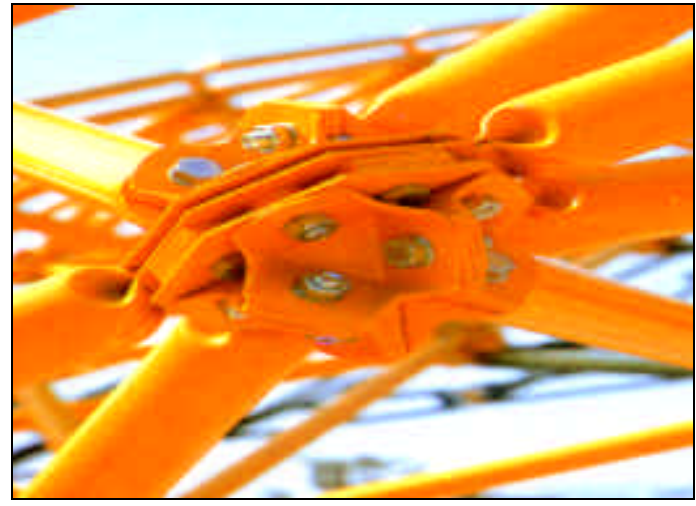

Sistema ECO

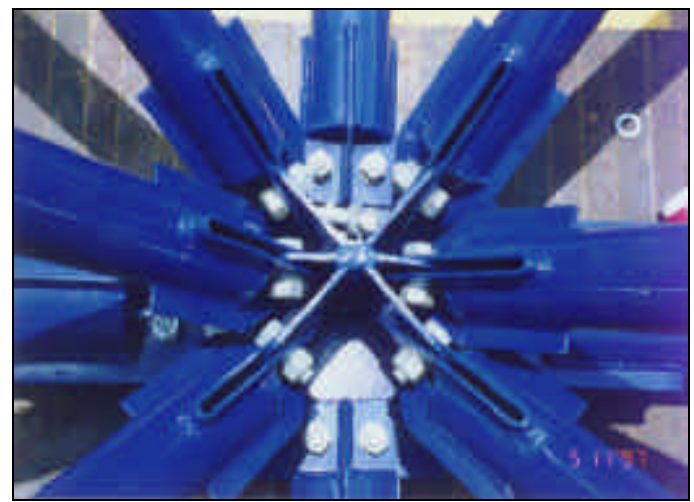

Sistema com ponteiras (Brasileiro)

Figura 3.2 - Sistemas de ligação utilizados em cúpulas

A tabela 3.1 apresenta uma descrição sucinta dos sistemas de ligação apresentados. 
Tabela 3.1 - Resumo dos sistemas de ligação

\begin{tabular}{|c|c|c|c|}
\hline Sistema & Patenteado & Descrição & Obsevação \\
\hline $\begin{array}{l}\text { TíPICO } \\
\text { (Brasileiro) }\end{array}$ & não & $\begin{array}{l}\text { Formado pela sobreposição das } \\
\text { extremidades das barras estampadas } \\
\text { conectadas por um único parafuso. }\end{array}$ & $\begin{array}{l}\text { Grandes excentricidades, } \\
\text { variação de inércia nas barras } \\
\text { e pequena rigidez. }\end{array}$ \\
\hline VESTRUT & $\operatorname{sim}$ & $\begin{array}{l}\text { Formado por barras de seção circular com } \\
\text { um parafuso na extremidade que se unem } \\
\text { por meio de duas calotas hemisférica com } \\
\text { auxílio de um parafuso. }\end{array}$ & $\begin{array}{l}\text { Custo elevado dos elementos } \\
\text { devida a alta trabalhabilidade } \\
\text { na extremidade das barras. }\end{array}$ \\
\hline OKTAPLANTTE & $\operatorname{sim}$ & $\begin{array}{l}\text { Formado por elementos de seção circular } \\
\text { que se unem a uma esfera de aço por meio } \\
\text { de solda. }\end{array}$ & $\begin{array}{l}\text { Dificuldades na montagem da } \\
\text { estrutura e problemas em } \\
\text { executar solda de campo. }\end{array}$ \\
\hline MERO (Alemão) & $\operatorname{sim}$ & $\begin{array}{l}\text { Formado por elementos tubulares de aço } \\
\text { com parafuso na extremidade que são } \\
\text { rosqueados em uma esfera de aço. }\end{array}$ & $\begin{array}{l}\text { Alta eficiência estrutural, } \\
\text { representando bem as } \\
\text { hipóteses adotadas na análise } \\
\text { numérica. }\end{array}$ \\
\hline Sistema Italiano & não & $\begin{array}{l}\text { Formado pela associação de chapas } \\
\text { planas conectadas às barras através de } \\
\text { parafusos. }\end{array}$ & $\begin{array}{l}\text { Bom comportamento estrutural, } \\
\text { apesar da variação de inércia } \\
\text { nas extremidades das barras. }\end{array}$ \\
\hline $\begin{array}{l}\text { Típico com } \\
\text { chapa } \\
\text { complementar }\end{array}$ & não & $\begin{array}{l}\text { Semelhante ao nó típico com chapa } \\
\text { adicional ligando as barras do banzo. }\end{array}$ & $\begin{array}{l}\text { Problemas devido a pequena } \\
\text { rigidez da chapa utilizada, } \\
\text { além dos problemas } \\
\text { apresentados para o nó típico. }\end{array}$ \\
\hline \begin{tabular}{|l} 
TRIODETIC \\
(Canadense)
\end{tabular} & $\operatorname{sim}$ & $\begin{array}{l}\text { Formado por barras de seção circular com } \\
\text { ranhuras nas extremidades que se } \\
\text { encaixam a um cilindro,fixado por um } \\
\text { parafuso. }\end{array}$ & $\begin{array}{l}\text { Baixa eficiência estrutural } \\
\text { devido ao sistema de encaixe } \\
\text { e redução da inércia da barra } \\
\text { na região nodal. }\end{array}$ \\
\hline NODUS & $\operatorname{sim}$ & $\begin{array}{l}\text { Formado por elementos tubulares com } \\
\text { rosca na extremidade que se unem por } \\
\text { meio de luvas e parafusos. }\end{array}$ & $\begin{array}{l}\text { Possibilidade de utilizar } \\
\text { elementos tubulares de seção } \\
\text { retangular; alta } \\
\text { trabalhabilidade na confecção } \\
\text { e excesso de componentes. }\end{array}$ \\
\hline $\begin{array}{l}\text { Nó composto } \\
\text { por chapas "nó } \\
\text { de aço" } \\
\text { (Brasileiro) } \\
\end{array}$ & não & $\begin{array}{l}\text { Elementos tubulares com extremidade } \\
\text { amassadas ligados por parafusos a um nó } \\
\text { formado por um conjunto de chapas. }\end{array}$ & $\begin{array}{l}\text { Desempenho estrutural } \\
\text { compatível,alta } \\
\text { trabalhabilidade na execução } \\
\text { do nó. } \\
\end{array}$ \\
\hline $\begin{array}{l}\text { PALC } \\
\text { (Espanhol) }\end{array}$ & sim & $\begin{array}{l}\text { Elementos tubulares com parafuso nas } \\
\text { extremidades ligados a uma esfera de aço } \\
\text { (semelhante ao sistema mero). }\end{array}$ & $\begin{array}{l}\text { Alta eficiência estrutural e } \\
\text { facilidade de montagem. }\end{array}$ \\
\hline ECO (Italiano) & $\operatorname{sim}$ & $\begin{array}{l}\text { Elementos tubulares com extremidades } \\
\text { amassadas conectados a um sistema de } \\
\text { chapas por parafusos. }\end{array}$ & $\begin{array}{l}\text { Variação de inércia nas } \\
\text { extremidades causada pelo } \\
\text { amassamento; eficiência } \\
\text { estrutural descutível. }\end{array}$ \\
\hline $\begin{array}{l}\text { Nó com } \\
\text { ponteiras } \\
\text { (Brasileiro) }\end{array}$ & não & $\begin{array}{l}\text { Elementos tubulares com aletas nas } \\
\text { extremidade ligados por parafusos a um nó } \\
\text { formado por um conjunto de chapas. }\end{array}$ & $\begin{array}{l}\text { Alta eficiência estrutural, sendo } \\
\text { o melhor sistema brasileiro. }\end{array}$ \\
\hline
\end{tabular}




\section{2- Apresentação de sistemas de ligação utilizados no Brasil}

No Brasil, com exceção de algumas obras que utilizam o sistema patenteado MERO, as ligações em treliças espaciais planas e cúpulas, constituídas por elementos de seção transversal circular, são realizadas pela estampagem das extremidades das barras que são sobrepostas e conectadas por um único parafuso, formando um nó. Sistema de ligação este denominado na EESC-USP como nó típico, projetado com poucos estudos e baseados em hipóteses simplistas.

A necessidade de melhor conhecer o comportamento estrutural, distribuição de tensões e deslocabilidade dos nós típicos, deve-se ao elevado número de acidentes ocorridos nos últimos anos com este sistema de ligação, sendo que por desconhecimento ou relapso, engenheiros têm projetado estruturas, muitas com grandes vãos, sem as devidos cuidados e com modelos numéricos simplistas.

Utiliza-se também ligações através de chapas de aço isoladas (ponteiras) ou associações de chapas formando um nó capaz de receber barras em várias direções.

Os principais sistemas de ligação utilizados no Brasil são descritos a seguir, ressalta-se que a denominação dos detalhes do nó apresentados aqui não são padronizados o que não impede que se encontre, em textos ou catálogos técnicos, o mesmo nó com outras denominações.

\subsection{1- Nó típico}

A maioria das treliças espaciais planas e cúpulas construídas no Brasil, utilizam o sistema típico formado pela sobreposição das extremidades estampadas das barras unidas por um único parafuso que, dentre os sistemas brasileiros é o que merece maior atenção. A figura 3.3 apresenta um detalhe deste sistema de ligação. 


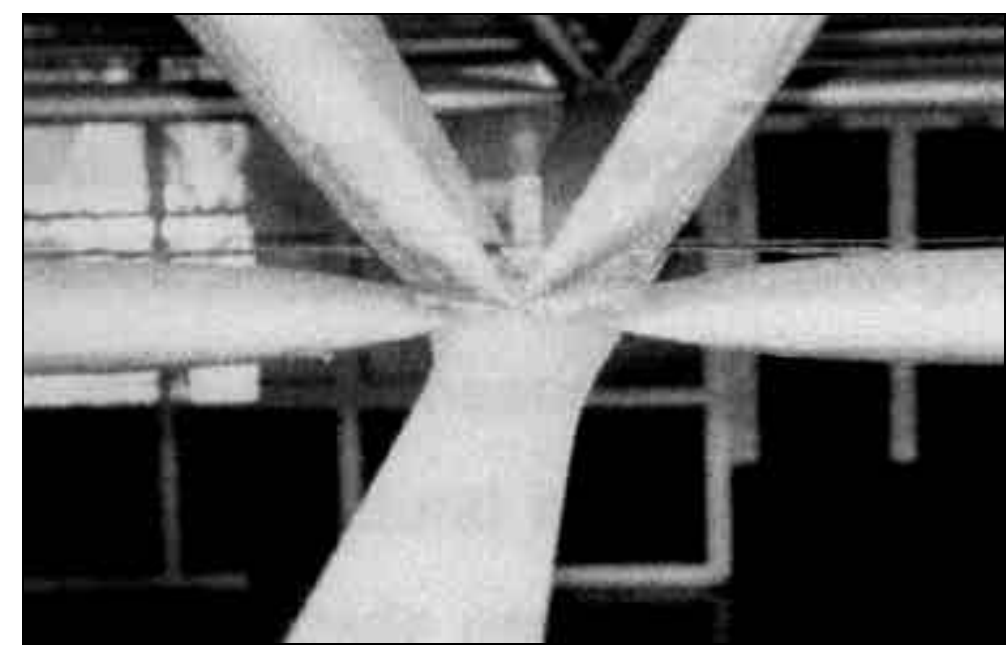

Figura 3.3 - Nó típico

Este sistema de ligação apresenta uma série de problemas. Em primeiro lugar o fato das barras serem ligadas por apenas um único parafuso, contrariando as recomendações de norma de utilizar no mínimo dois parafusos em linha por ligação.

Em segundo lugar, existe excentricidades nas ligações, provocando o surgimento de momento fletores nas barras acarretando em plastificação precoce nas extremidades estampadas, sobretudo nas diagonais que também têm suas extremidades dobradas.

Outro problema, digno de nota, deste tipo de ligação é o escorregamento relativo entre as extremidades das barras, pelo fato de serem conectadas por um único parafuso, produzindo aumento significativo nos deslocamento verticais.

Devido a todos esses problemas, as hipóteses adotadas nos modelos matemáticos para análise deste tipo de estrutura não são satisfeitas, o que pode acarretar em resultados não condizentes com a realidade da estrutura.

Ensaios realizados no Laboratório do Departamento de Engenharia de Estruturas da EESC-USP de protótipos de estruturas espaciais planas utilizando este sistema de ligação, mostram que os resultados de carga última da estrutura são inferiores aos valores obtidos teoricamente devido aos problemas já apresentados. 
Outro aspecto observado nos ensaios é a rotação excessiva da região nodal que pode conduzir a duas situações: a primeira, indução a plastificação da região estampada das barras (Figura 3.4) e a segunda, conduzir a uma flambagem precoce das barras que compõe a estrutura.

A figura 3.4 apresenta a plastificação da extremidade da barra no protótipo ensaiado.

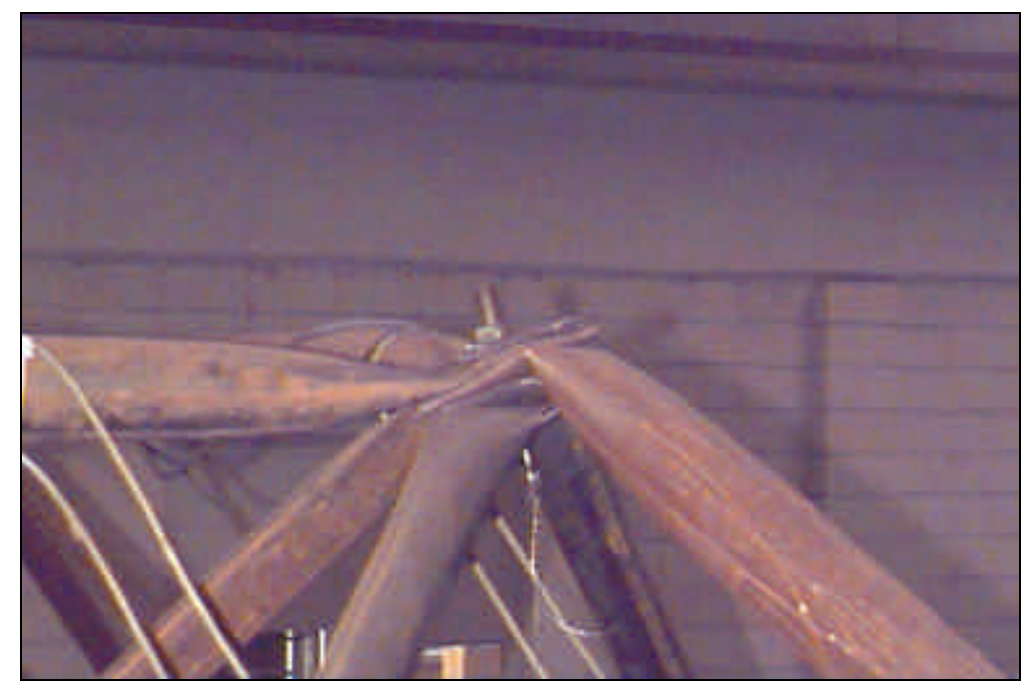

Figura 3.4 - Plastificação da extremidade da barra

A figura 3.5 apresenta a fase construtiva de uma estrutura em forma de cúpula utilizando este sistema de ligação.

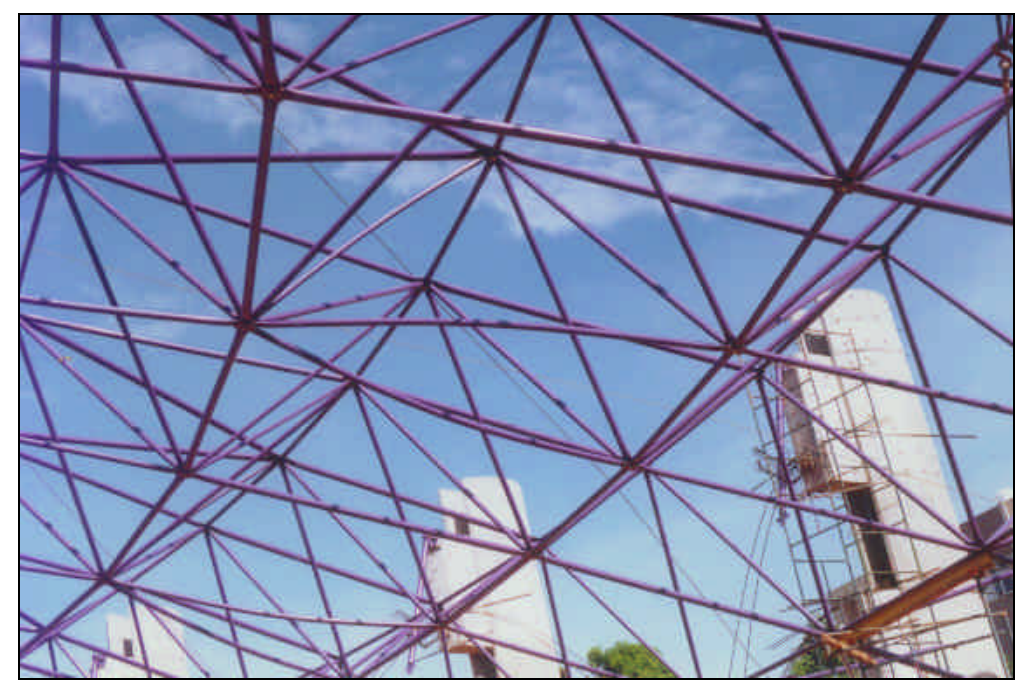

Figura 3.5 - Cúpula com sistema de ligação típico 
Portanto, salienta-se que, apesar deste sistema de ligação ser amplamente utilizado, o mesmo ainda necessita de estudos que esclareçam seu comportamento, evitando assim problemas futuros com este sistema de ligação.

\subsection{2- Nó com chapa complementar}

O nó com chapa complementar é bastante semelhante ao nó típico sendo que a diferença está na utilização de chapas horizontais para ligar as barras do banzo, como mostra a figura 3.6.

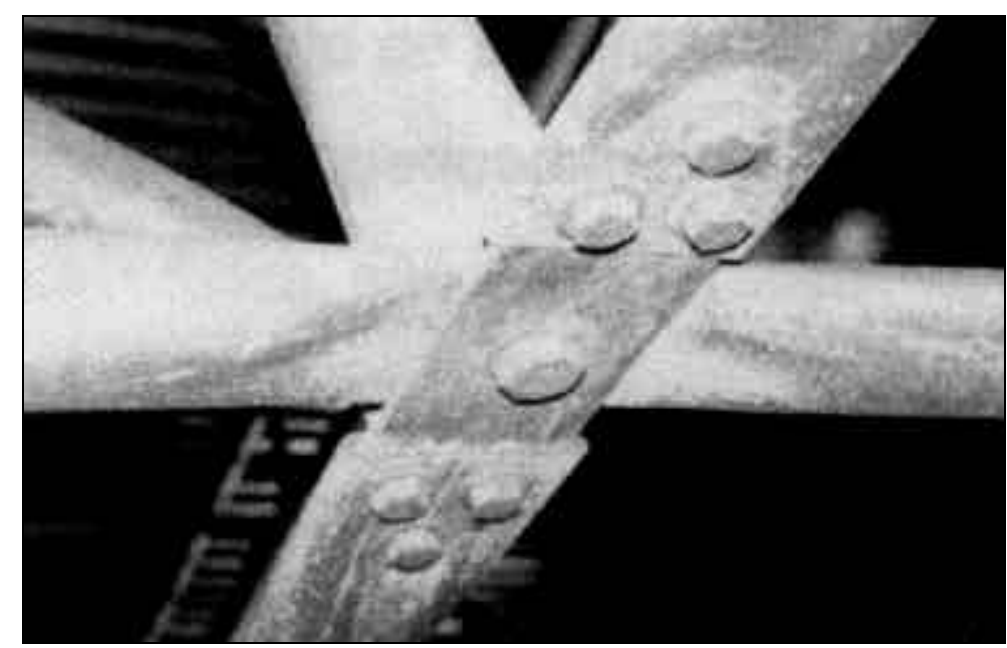

Figura 3.6 - Nó típico com chapa complementar

Essas chapas são empregadas quando os esforços nos banzos são elevados e de tal ordem que o uso de apenas um parafuso não tem resistência suficiente para resistir os esforços solicitantes, sendo necessário maior número de parafusos para aumentar a capacidade da ligação.

Estas ligações apresentam, além dos aspectos relatados para o nó típico, um problema adicional que é o fato das chapas que fazem a ligação dos banzos possuírem pequena rigidez. Para os banzos comprimidos uma pequena excentricidade, perpendicular ao plano da chapa, pode 
comprometer o desempenho da ligação, conduzindo a um colapso com forças normais inferiores à capacidade da barra.

\subsection{3- Nó composto por chapas ${ }^{1}$ ("nó de aço")}

Neste sistema, as extremidades das barras são conectadas através de parafusos diretamente em um nó confeccionado com chapas de aço o que elimina os problemas com excentricidades uma vez que as chapas que constituem o nó concorrem para um único ponto.

Portanto, dentre os sistemas de ligação utilizados no Brasil, o nó de aço é um dos que tem melhor desempenho, produzindo efetivamente um nó de melhor comportamento estrutural, porém utilizando barras com extremidade estampada. A figura 3.7 apresenta um detalhe do nó de aço.

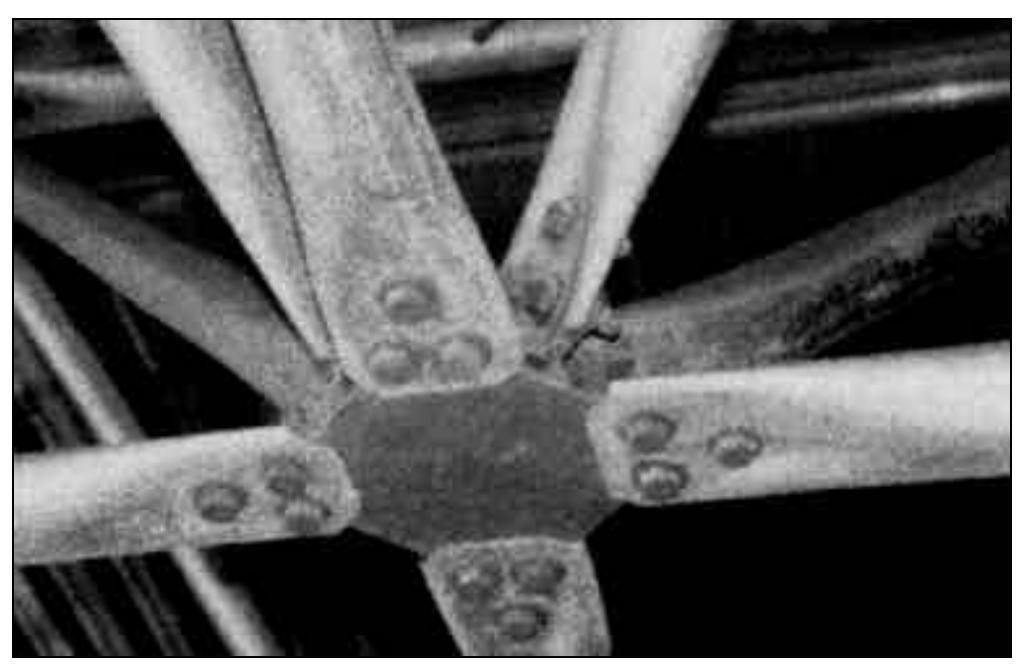

Figura 3.7 - Nó de aço

Ensaios realizados no Laboratório do Departamento de Engenharia de Estruturas da EESC-USP de protótipos de estruturas espaciais planas utilizando este sistema de ligação, mostram que a estrutura chega a carga última pela flambagem dos elementos e não devido a problemas localizados na região de estampagem das barras como acontece com o protótipo

\footnotetext{
${ }^{1}$ Neste trabalho admiti-se a nomenclatura nó de aço para este sistema de ligação.
} 
utilizando o nó típico. A figura 3.8 apresenta a perda de estabilidade do protótipo pela flambagem dos elementos.

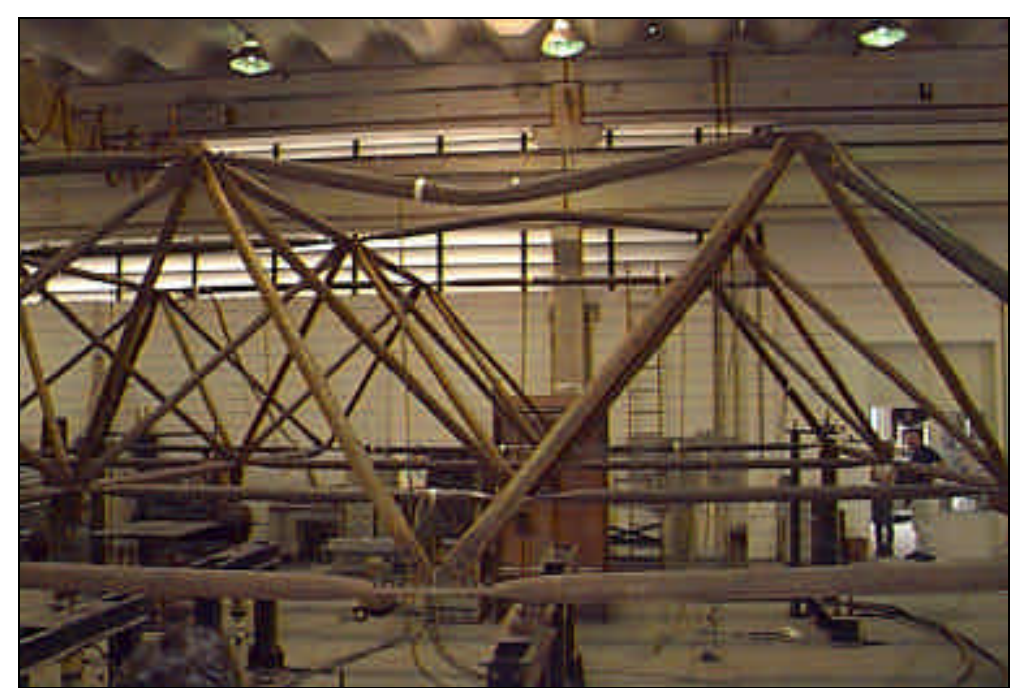

Figura 3.8 - Flambagem dos elementos que constituem o protótipo

Salienta-se que para este tipo de ligação é necessário dimensionar os elementos considerando a variação de inércia, sendo que este aspecto não será melhor detalhado neste trabalho, pois foi objeto da Dissertação de Mestrado, Souza (1998), desenvolvida no Departamento de Engenharia de Estruturas da EESC-USP.

\subsection{4- Nó com chapa de extremidade (ponteira)}

Este sistema de ligação, evita a redução de inércia da extremidade da barra devido a estampagem para confecção do nó. Neste sistema, duas chapas paralelas são soldadas em abertura na extremidade do tubo e conectadas a chapa de apoio por meio de parafusos. A figura 3.9 apresenta um detalhe esquemático desta ligação. 


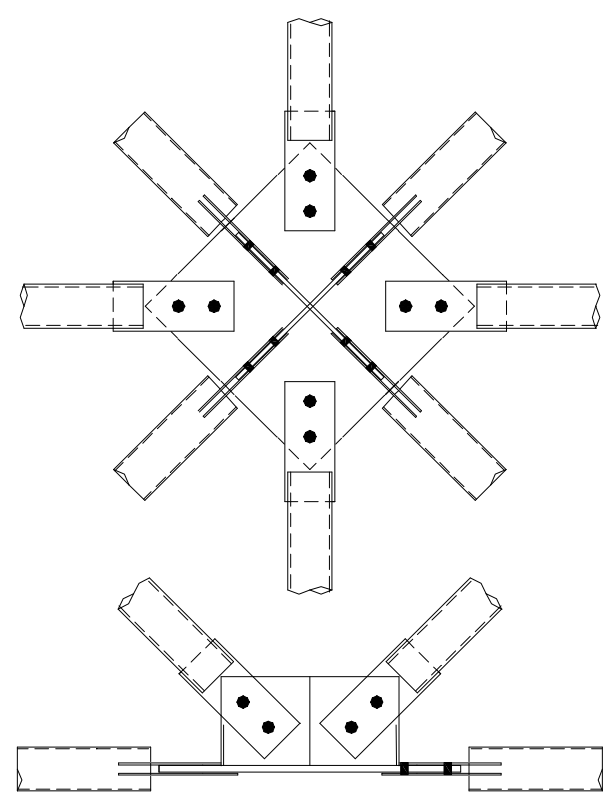

Figura 3.9 - Detalhe esquemático do nó com chapa de extremidade

Embora não haja excentricidades neste tipo de ligação, as chapas de extremidades apresentam pequena rigidez perpendicular a seu plano, o que pode comprometer a ligação.

Uma alternativa para minimizar este problema é a adoção de chapas (aletas) soldadas perpendicularmente às ponteiras, que funcionam como enrijecedores melhorando o desempenho da ligação. A figura 3.10 apresenta uma ligação com chapas de ponteiras enrijecidas com aletas perpendiculares. 


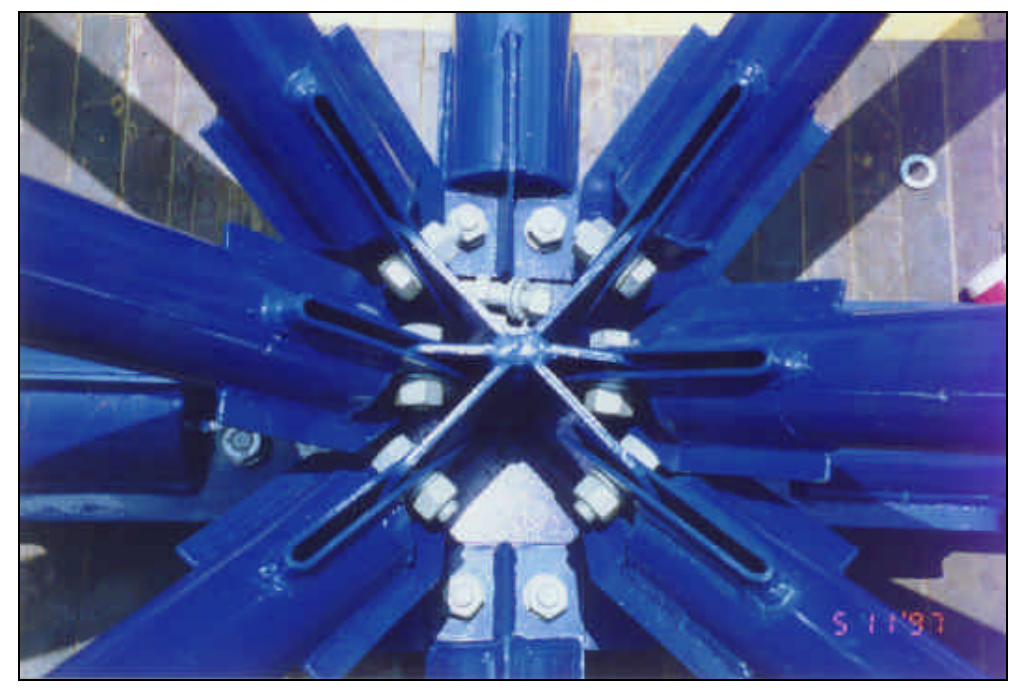

Figura 3.10 - Ligação com chapa de ponteira

A utilização de nervuras e aletas constitui-se no melhor sistema de nós utilizados no Brasil, além de permitir o cálculo corrente, ou seja, o cálculo estático admitindo que os nós são rotulados e as barras distam de ponto de trabalho a ponto de trabalho.

\section{3 - Comentários finais}

Pôde-se observar que as hipóteses freqüentemente assumidas nos modelos matemáticos utilizados para o cálculo dos esforços atuantes em estruturas espaciais constituídas por elementos tubulares que utilizam os sistemas de ligação utilizados em nosso país não condizem com a realidade da estrutura. Portanto, estes sistemas de ligações necessitam de estudos mais detalhados que expliquem o seu comportamento e permitam utilizar correções dos resultados obtidos quando admitido às hipóteses correntes, ou seja, treliças espaciais com nós rotulados.

Os objetivos dos estudos realizados na EESC-USP são avaliar os problemas existentes nestes sistemas de ligação, em particular para os modos de colapso, para alertar os profissionais envolvidos nestes projetos sobre os riscos de utilização, ou até mesmo limitar o uso desses sistemas 
de ligação para estruturas de grandes dimensões, quando admitidas às hipóteses correntes, ou seja, treliças espaciais com nós rotulados.

No capítulo 4 apresenta-se os resultados dos estudos numéricos do nó típico, considerando vários aspectos pertinentes a este tipo de ligação. 


\section{Análise numérica do nó típico}

A maioria das cúpulas construídas no Brasil são constituídas por elementos tubulares com seção transversal circular em aço utilizando o sistema de ligação denominado nó típico. Apresenta-se um exemplo deste tipo de estrutura na figura 4.1 e o detalhe de montagem na figura 4.2.

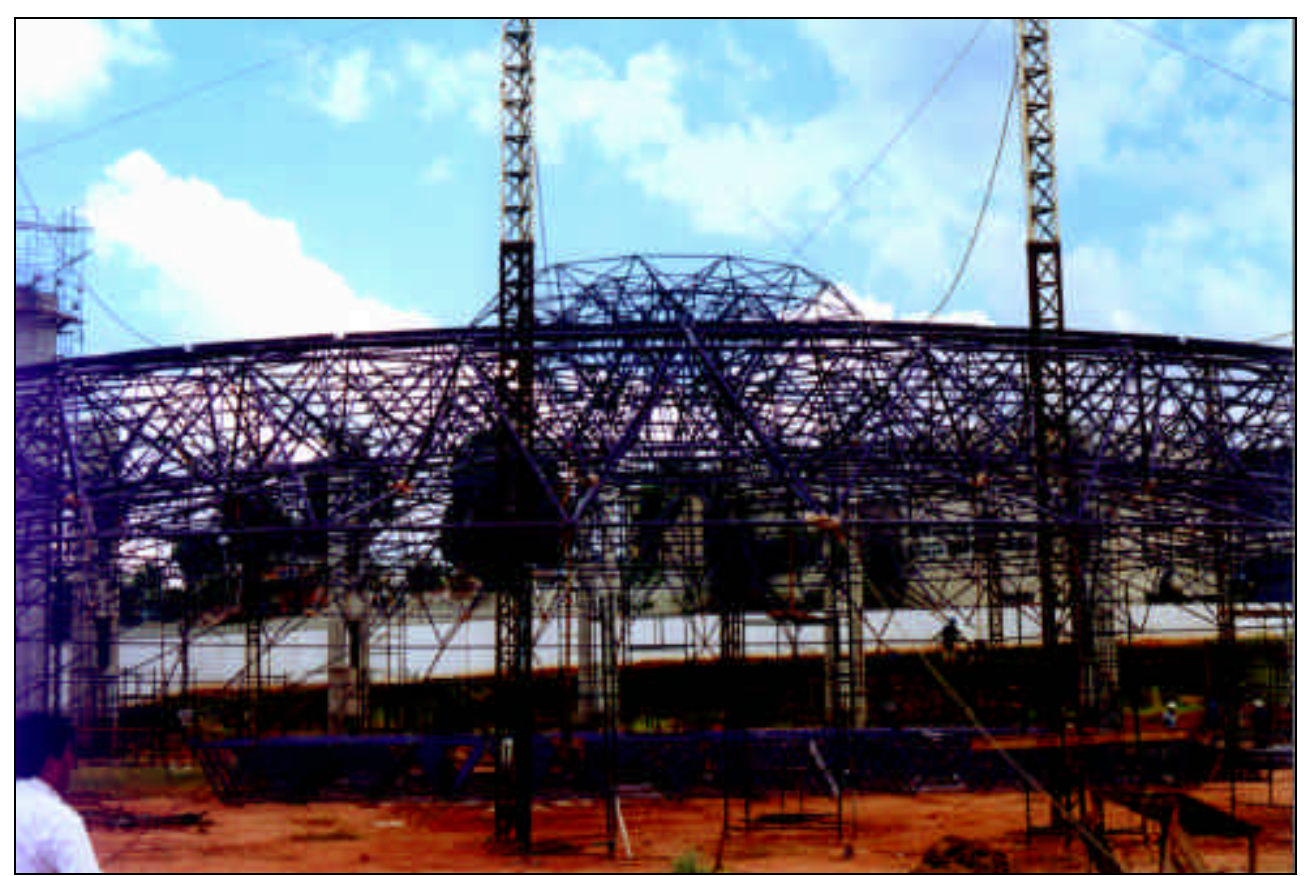

Figura 4.1 - Exemplo de cúpulas utilizadas em nosso país (diâmetro=80.8m) 


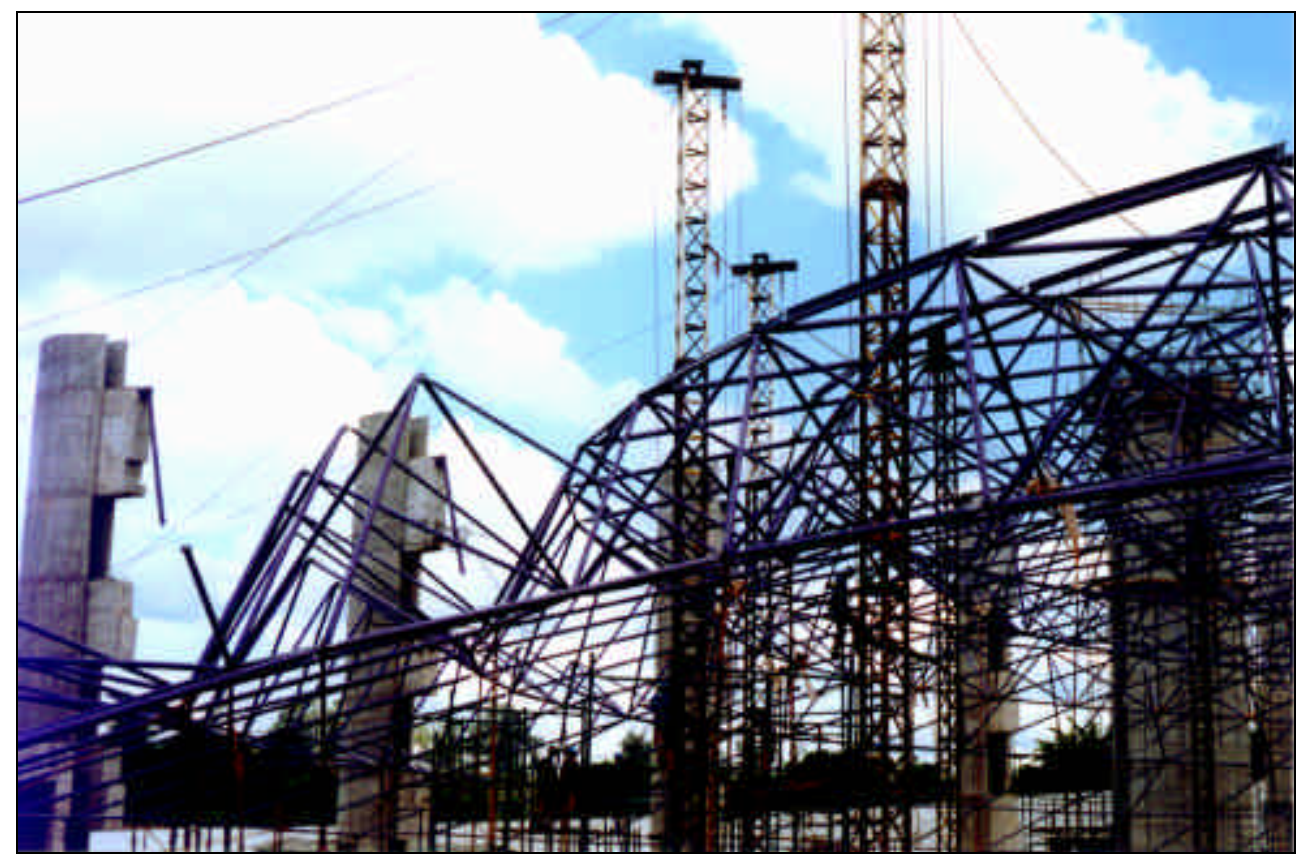

Figura 4.2 - Detalhe de montagem da cúpula

As estruturas que utilizam o nó típico, apresentam alguns problemas com este tipo de ligação. O seu comportamento, descrito no capítulo anterior, faz com que o modelo de análise, baseado na treliça ideal, não reproduza o seu comportamento, podendo acarretar em insegurança na estrutura.

O objetivo deste capítulo é simular o comportamento deste sistema de ligação, mesmo que simplificadamente, quando o mesmo se encontra inserido na estrutura.

Sendo uma análise experimental imprescindível para se conhecer 0 funcionamento de uma dada estrutura e também para avaliar se as hipóteses adotadas nos modelos matemáticos são convenientes, o nó típico foi inserido em uma estrutura espacial plana, uma vez que podíamos dispor dos resultados experimentais de protótipos deste tipo de estrutura.

Estes protótipos foram ensaiados no Laboratório de Engenharia de Estruturas da EESC-USP, e os resultados completos estão apresentados na dissertação de mestrado do Eng. ${ }^{\circ}$ Carlos Henrique Maiola, cujo objetivo é a análise experimental do comportamento deste tipo de ligação em estruturas espaciais planas. 
Mesmo que o presente trabalho esteja vinculado ao assunto de cúpulas, optou-se por utilizar os protótipos de treliças espaciais planas para modelagem do nó típico. Porém, sabe-se que os problemas deste tipo de nó são ainda maiores nas cúpulas devido aos elementos do banzo não estarem alinhados.

Prevêem-se futuros trabalhos que permitam estender esta análise para cúpulas, seguida de ensaios de protótipos deste tipo de estrutura para verificação das hipóteses matemáticas utilizadas nas análises numéricas.

\section{1- Descrição do protótipo ensaiado}

O protótipo ensaiado é uma treliça espacial formada por elementos tubulares de seção circular em aço USI-SAC-41 conformados a frio e com solda de costura. Os parafusos utilizados em todas as ligações são do tipo ASTM-A325.

A estrutura é constituída de duas camadas ou banzos, dispostas de forma paralela e plana com configuração de malha quadrada sobre quadrada, unidas por elementos diagonais formando um reticulado de forma piramidal.

Os elementos possuem suas extremidades estampadas, que se sobrepõe formando o nó típico. As seções dos elementos utilizados na treliça espacial e suas respectivas forças nominais resistentes à compressão são apresentadas na tabela 4.1. A força nominal resistente à compressão das barras foi calculada segundo a NBR 8800/86, admitindo o seu comprimento de flambagem como de ponto de trabalho a ponto de trabalho.

Foram retirados corpos de prova para a caracterização do aço, sendo obtido o valor médio de $350 M P a$ para tensão de escoamento, que será utilizada para as análises teóricas de tal forma a permitir comparar com os resultados experimentais. 
Tabela 4.1 - Elementos utilizados no protótipo ensaiado

\begin{tabular}{|c|c|c|c|c|c|}
\hline Tubo & Utilização & Área $\left(\mathrm{mm}^{2}\right)$ & Compr. $(\mathrm{mm})$ & Esbeltez & $\mathrm{N}_{\mathrm{ck}}(\mathrm{kN})$ \\
\hline $\mathbf{6 \mathbf { 6 0 } \mathbf { 2 } , \mathbf { 0 }}$ & Diagonal & 364 & 2318 & 113 & 49,0 \\
\hline \multirow{2}{*}{$\phi \mathbf{7 6 \times 2 , 0}$} & Banzo & 465 & 2500 & 95,4 & 83,0 \\
\cline { 2 - 6 } & Diagonal apoio & 465 & 2318 & 88,5 & 92,0 \\
\hline
\end{tabular}

Observação: $N_{c k}=\rho A_{g} f_{y}^{*} \quad f_{y}^{*}=350 \mathrm{MPa}$ (ensaio)

A estrutura foi apoiada no seus quatro nós extremos inferiores, em colunas de aço, as quais por sua vez foram engastadas à laje de reação.

A aplicação de força se deu nos quatro nós centrais, no sentido gravitacional. A figura 4.3 apresenta as características e dimensões do protótipos ensaiado.

- Pontos de aplicacāo de forca

Apoios
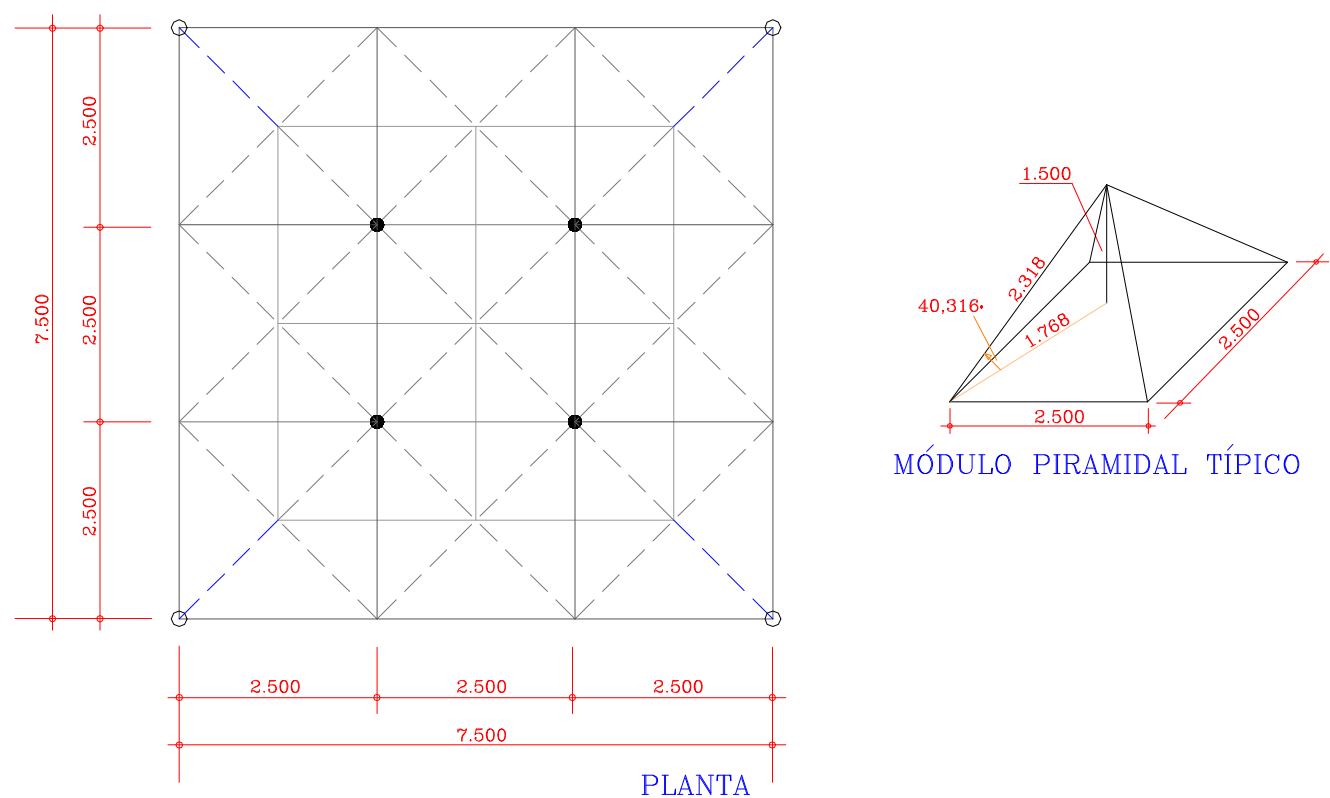

MÓDULO PIRAMIDAL TÍPICO

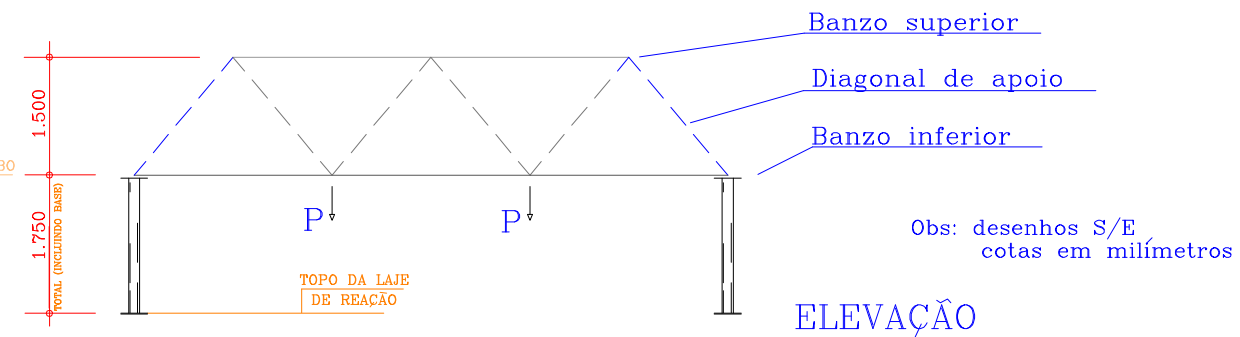

Figura 4.3 - Características e dimensões do protótipo ensaiado 
A figura 4.4 apresenta a estrutura montada no Laboratório de Estruturas da EESC-USP.

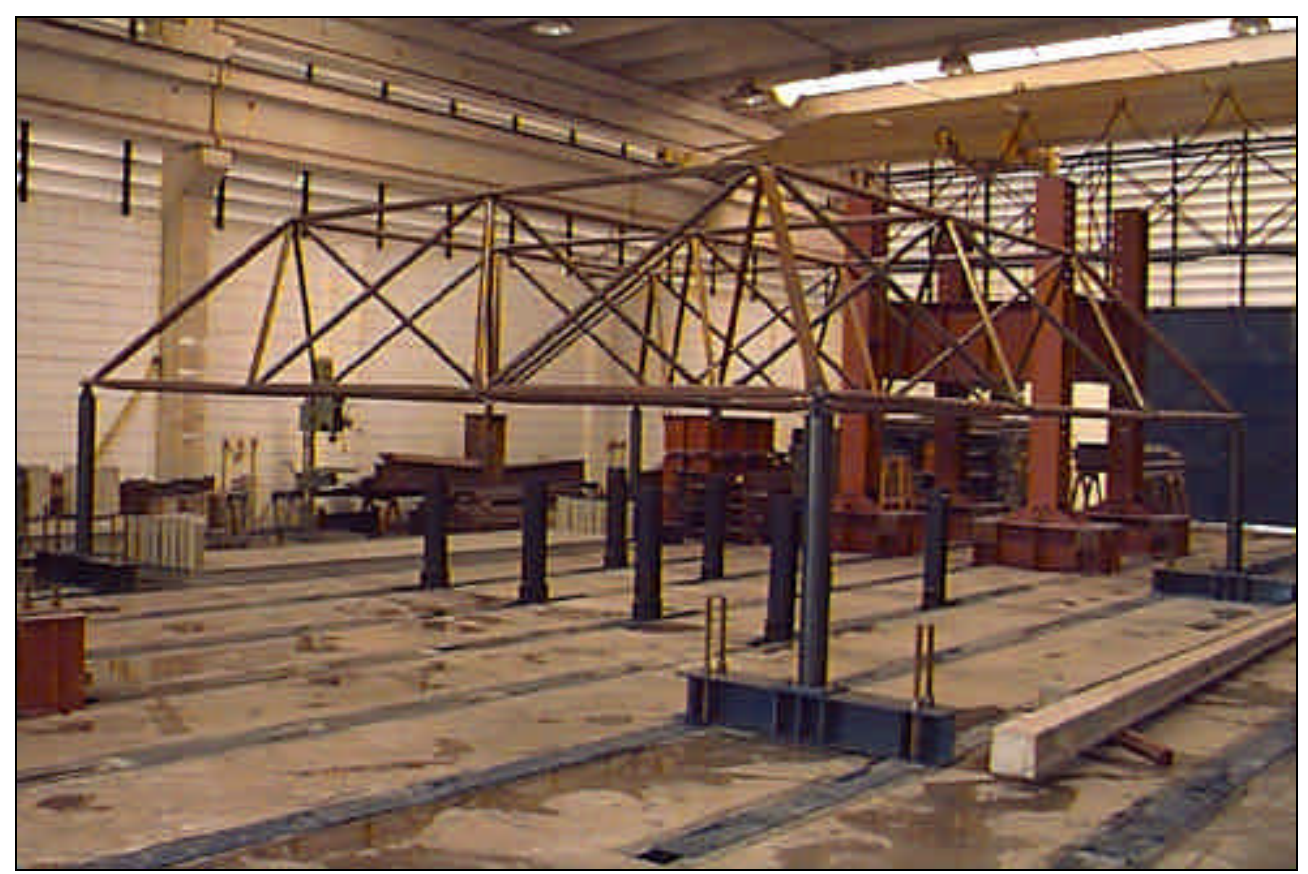

Figura 4.4 - Protótipo montado no laboratório

\subsection{1- Instrumentação e metodologia do ensaio}

A estrutura ensaiada foi instrumentada para obter deslocamentos e deformações, ambas necessárias para avaliação do comportamento da estrutura.

Para medição dos deslocamentos verticais e horizontais da estrutura, utilizou-se transdutores de deslocamentos da marca KYOWA, com sensibilidade de escala de $0,02 \mathrm{~mm}$ e $0,04 \mathrm{~mm}$ e fundo de escala de $50 \mathrm{~mm}$ e $100 \mathrm{~mm}$, respectivamente.

$\mathrm{Na}$ medição das deformações nas barras, utilizaram-se extensômetros elétricos de resistência, marca KYOWA, modelo KFG-5$120 \mathrm{C} 1-11$, com base de $5,0 \mathrm{~mm}$, resistência de $120 \Omega$ e "gage factor" de 2,15 . 
As forças foram aplicadas no nós do banzo inferior, por meio de atuadores hidráulicos com pistão vazado da marca ENERPAC, modelo RCH com capacidade de $300 \mathrm{kN}$ e para medição das forças aplicadas utilizaramse células de carga com capacidade de $300 \mathrm{kN}$. Toda a instrumentação foi conectada a um sistema de aquisição automática de dados SYSTEM 4000.

A figura 4.5 apresenta a instrumentação completa da estrutura com as respectivas indicações das barras e nós em que foram efetuadas medições de deformações e deslocamentos.
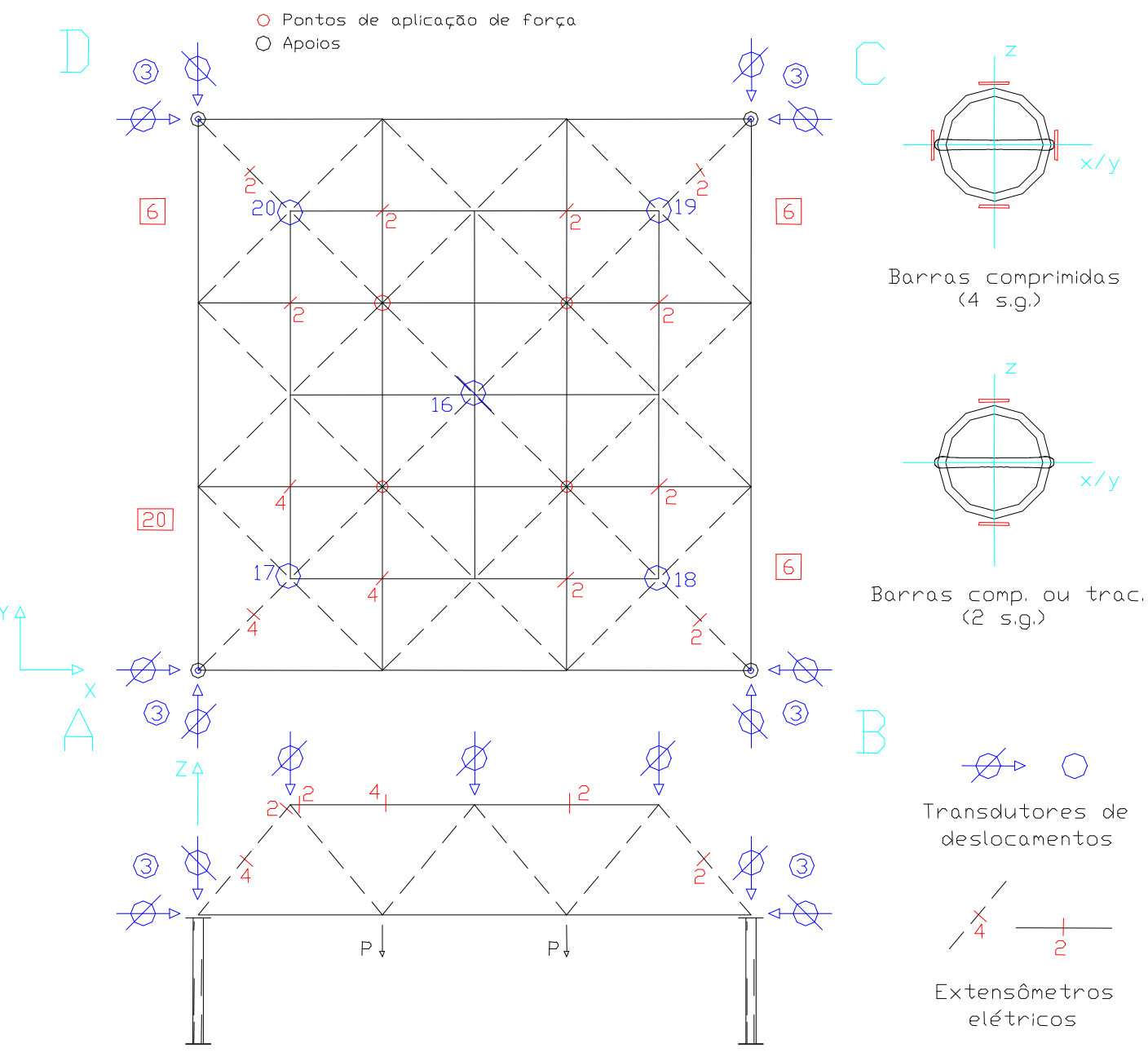
(2) 5.9 .

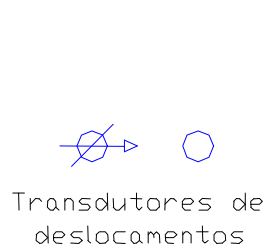

Figura 4.5 - Esquema da instrumentação da estrutura

As figuras $4.6 \mathrm{a}$ e $4.6 \mathrm{~b}$ ilustram o detalhe da instrumentação das barras com extensômetros elétricos de resistência e os transdutores de deslocamentos na região de apoio, respectivamente. 


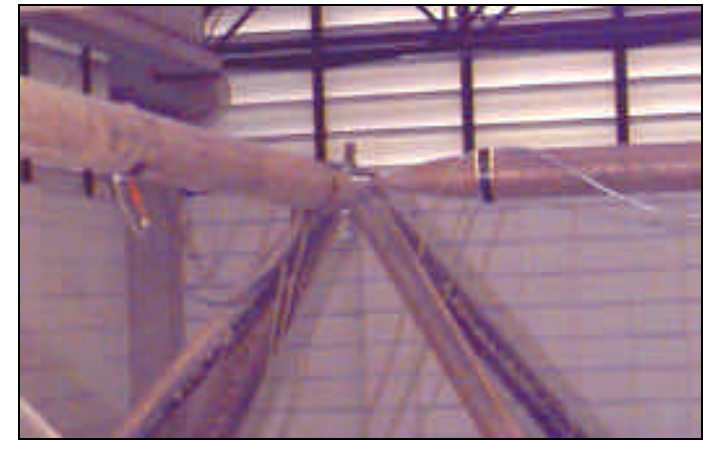

(a)

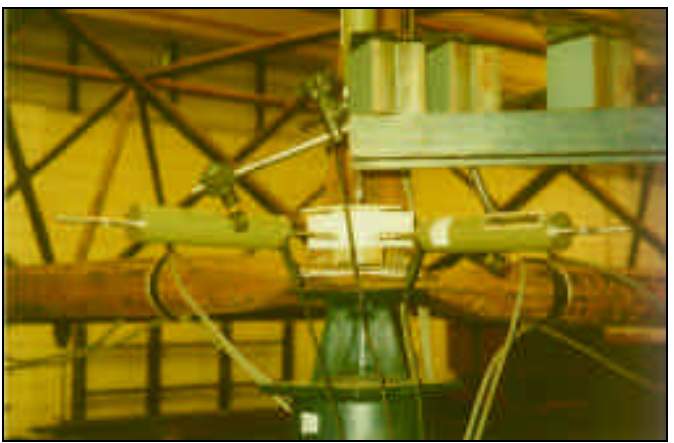

(b)

Figura 4.6 - Detalhe da instrumentação

\section{2- Comentários sobre o ensaio do protótipo}

A figura 4.7 apresenta a ruína do protótipo provocado pela plastificação da extremidade da barra associada a deformação excessiva da chapa que constitui a arruela, enfatizando o giro excessivo do parafuso.

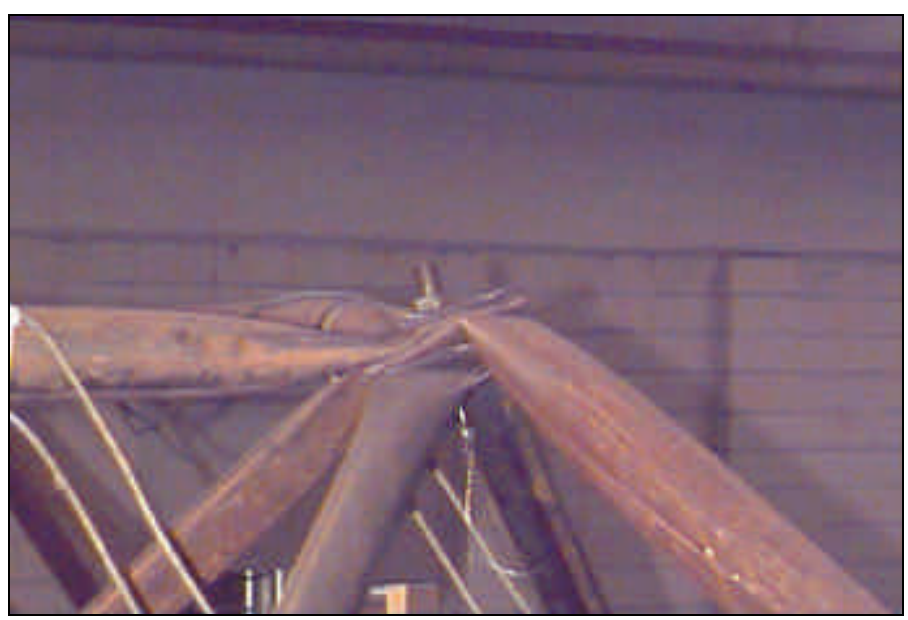

Figura 4.7 - Plasticação da extremidade da barra

Apresenta-se, a seguir, alguns dos resultados obtidos experimentalmente e os obtidos através de simulação numérica admitida a treliça ideal e comportamento linear, hipóteses utilizadas no cálculo corrente dos escritórios de projetos.

Os gráficos das figuras 4.8 e 4.9 ilustram os resultados teóricos (treliça ideal) e experimentais para o deslocamento do nó central da treliça 
e deformação da diagonal de apoio em função da força aplicada em cada atuador hidráulico, respectivamente.

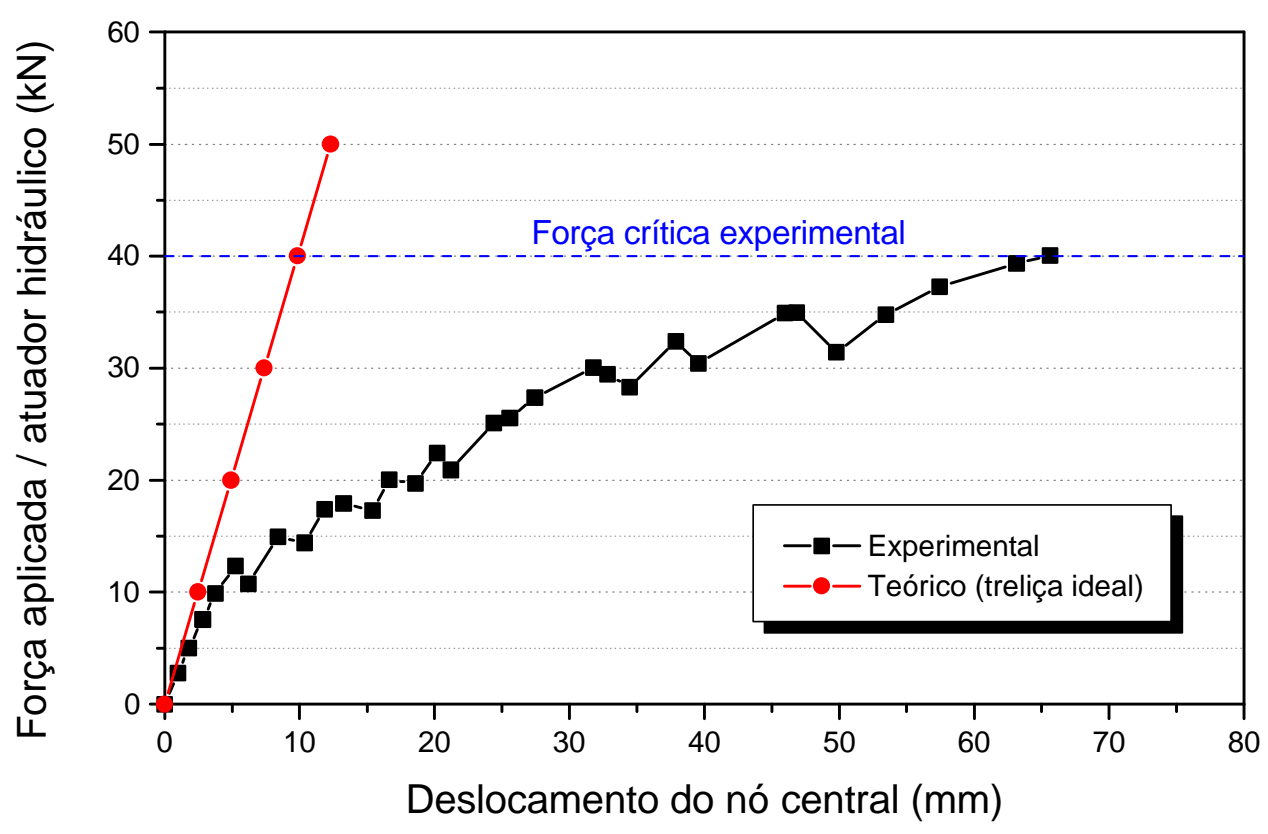

Figura 4.8 - Deslocamento teórico e experimental do nó central

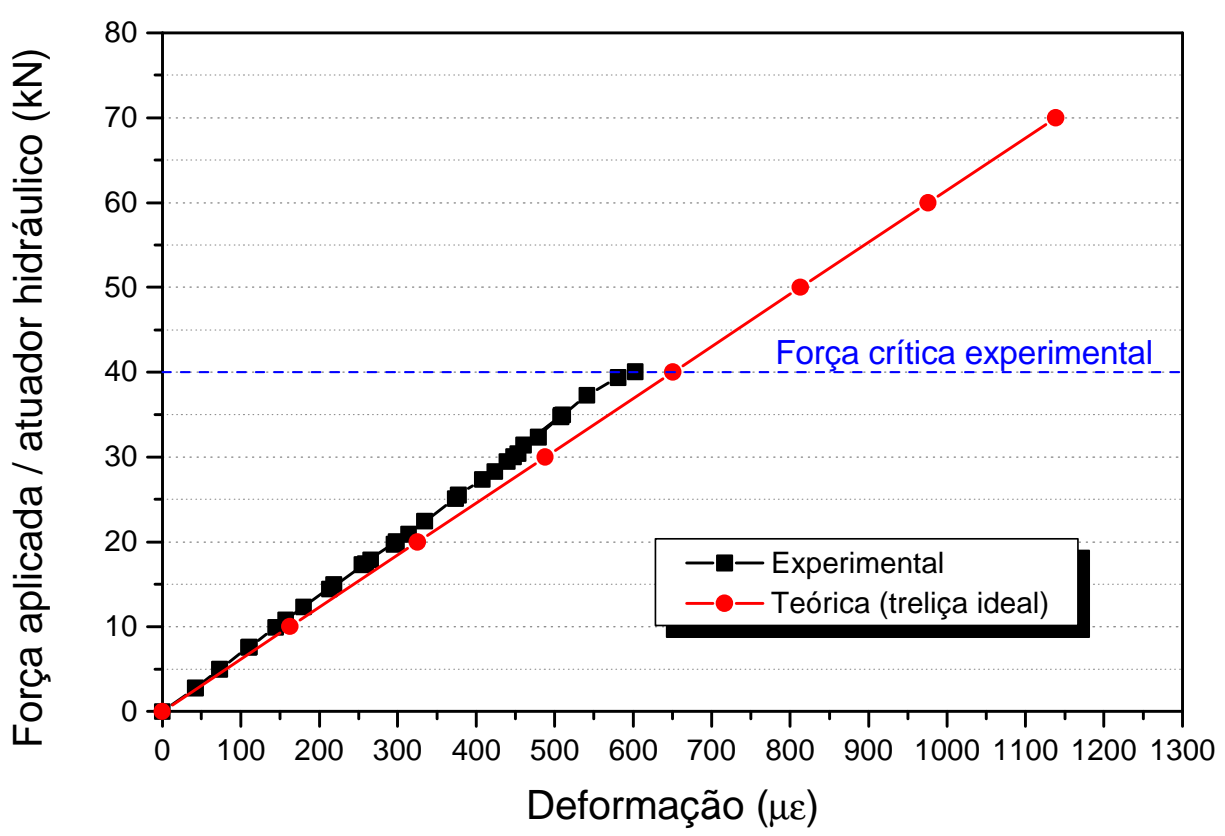

Figura 4.9 - Deformações de compressão média na seção transversal da diagonal de apoio 
A título de ilustração a força de compressão atuando na diagonal de apoio, medida no ensaio, foi de $57.4 \mathrm{kN}\left(F=E^{*} \varepsilon^{*} A_{g}\right)$ enquanto que a força normal resistente, admitindo as hipóteses de nós rotulados e sem variação de inércia, é $92.0 \mathrm{kN}$, como indicado na tabela 4.1.

Pode-se concluir, pela análise dos resultados apresentados na figura 4.8, que as hipóteses admitidas no modelo teórico (treliça ideal e comportamento linear) não representam o modelo físico.

Enquanto os resultados teóricos do deslocamento são lineares, os resultados experimentais indicam um comportamento não-linear em função, principalmente, dos escorregamentos e rotações excessivas na região do nós típicos.

Pela figura 4.9, observa-se que as deformações e, portanto, os esforços nas seções centrais da barra permanecem em regime elástico linear enquanto que, nas seções da região nodal, ocorre plastificação, caracterizando o módulo de falha deste nó. Plastificação esta decorrente dos momentos provenientes das excentricidades existentes na região da barra com inércia reduzida.

Associa-se a isto a elevada rotação nodal, observada em todos os ensaios, o que contribui para uma redução na carga crítica se comparada com os resultados obtidos numericamente, não considerando a variação de inércia das extremidade das barras e a influência do comportamento do nó.

Em função destes problemas constata-se a necessidade de conhecer melhor o comportamento deste sistema de ligação, modelando-o com elemento finito de casca para melhor simular os efeitos que ocorre nesta região, devido ao amassamento das extremidades das barras e excentricidades. 


\section{3 - Modelagem da extremidade da barra}

Com o intuito de simular o comportamento da extremidade da barra, onde ocorre a plastificação, a mesma foi modelada com auxílio do programa de análise com elementos finitos, ANSYS.

Para modelar esta região, a geometria de várias seções transversais espaçadas de $3 \mathrm{~cm}$ foram medidas com auxílio de uma mesa de coordenadas pertencente ao Departamento de Engenharia Elétrica da EESC-USP.

Para cada seção transversal, obtiveram-se as coordenadas de vários pontos e, com auxílio do programa ANSYS, construiu-se, por meio de linhas, o contorno da respectiva seção transversal como pode ser observado na figura 4.10a.

Definida a geometria, foi possível gerar uma área contornando a região externa das várias seções transversais formadas pelas linhas, construindo assim, a extremidade do tubo, como pode ser visto na figura 4.10b. Essa extremidade foi toda discretizada com elemento finitos de casca em todo seu domínio como apresenta a figura 4.10c.

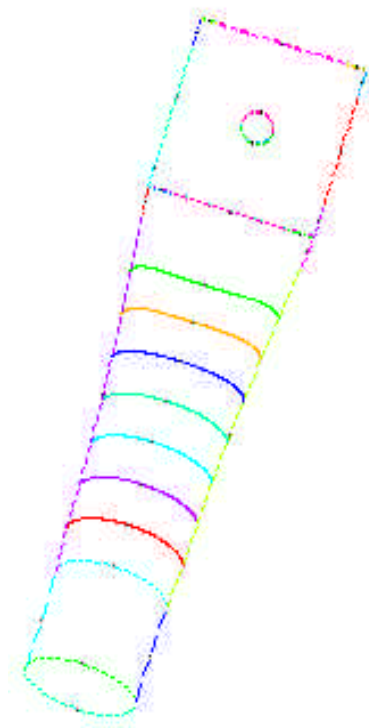

(a)

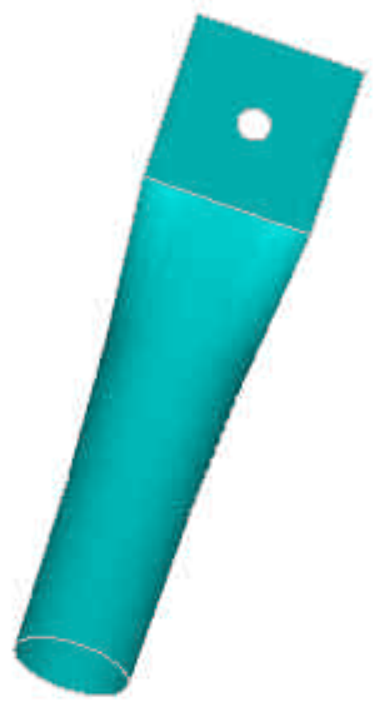

(b)

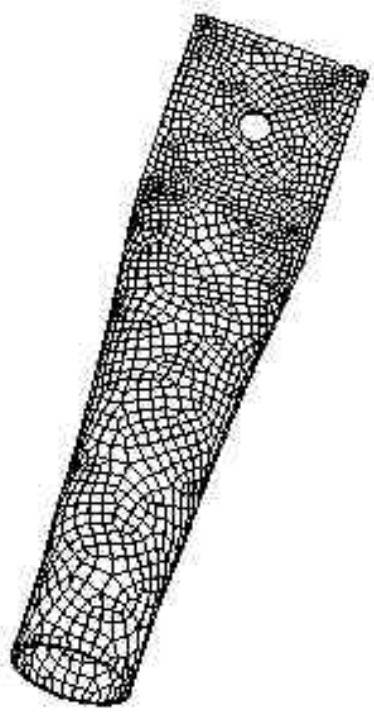

(c)

Figura 4.10 - Modelagem da extremidade da barra 


\section{4- Descrição dos elementos utilizados}

\subsection{1- Elemento finito de casca}

O elemento de casca utilizado na discretização do modelo é o SHELL43 da biblioteca de elementos do ANSYS. Este elemento é adequado para análise não-linear de estruturas planas ou curvas, com espessura moderada permitindo grandes descolamentos e grandes deformações. $O$ elemento possui seis graus de liberdade em cada nó sendo três translações nas direções $x, y$ e $z$ e três rotações em torno dos eixos $x, y$ e z.

O elemento é definido por quatro nós, quatro espessuras e a propriedade do material. A geometria, localização dos nós e o sistema de coordenadas para este elemento estão apresentados na figura 4.11.

Pressão e temperatura podem ser aplicadas ao elemento. A primeira como carregamento de superfície sobre a face do elemento como indicado nos círculos de 1 a 6 e a segunda fornecida ao elemento nos cantos indicados pelos números de 1 a 8 , como pode ser visto na figura 4.11 .

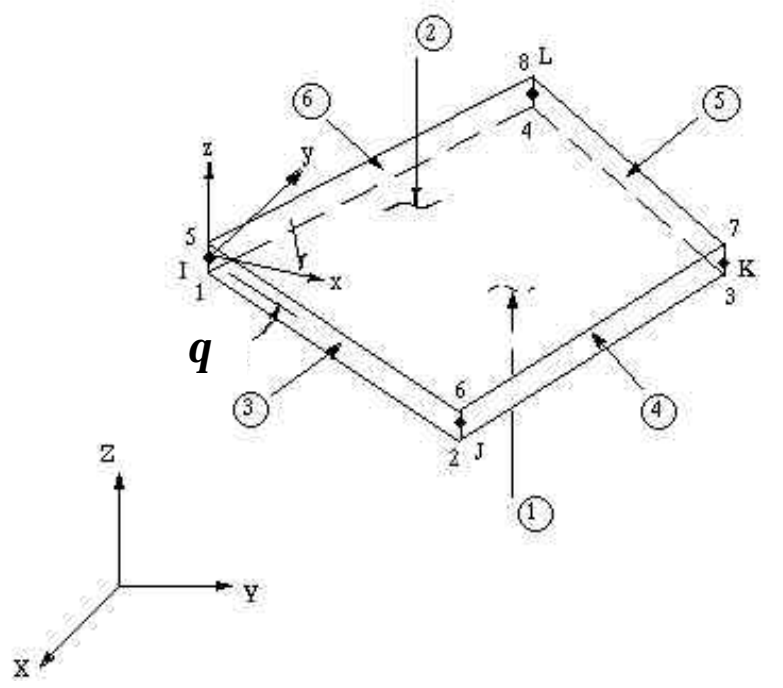

Figura $4.11^{1}$ - Elemento SHELL 43

${ }^{1}$ Ansys Elements Reference - Release 5.4 (1997) 


\subsection{2- Elemento finito de barra}

Outro elemento utilizado nos modelos estudados foi o BEAM24 também pertencente à biblioteca de elementos do ANSYS. Este elemento permite seção transversal arbitrária e seis graus de liberdade em cada nó sendo três translações nas direções $x, y$ e $z$ e três rotações sobre os eixos $x, y$ e $z$.

A seção transversal é formada por uma série de segmentos retos no plano $y-z$ do elemento e a localização do nó pode ser no centroide ou no centro de cisalhamento da seção, dependendo da opção feita pelo usuário.

A orientação da viga sobre o eixo longitudinal é especificada por um terceiro nó K, sempre requerido para definir o sistema de eixos do elemento, que não deve ser colinear com os nós I e J. A geometria, localização dos nós e o sistema de coordenada para este elemento estão apresentados na figura 4.12.

As forças são aplicadas nos nós, e as pressões podem ser aplicadas sobre a face do elemento como mostra os círculos de 1 a 5 na figura 4.12.

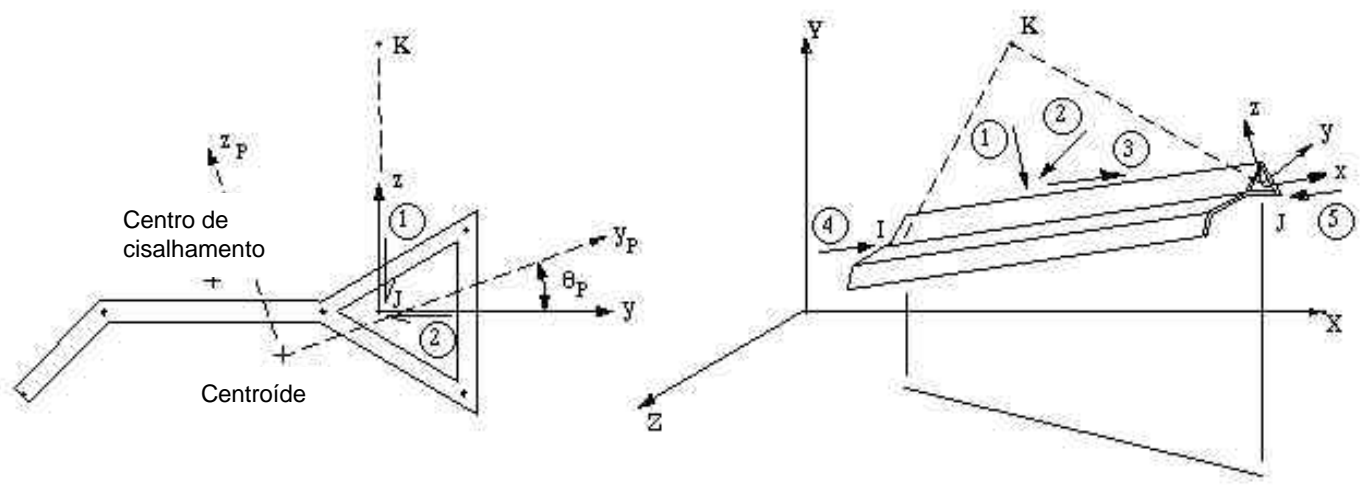

Figura $4.12^{1}$ - Elemento BEAM 24

A utilização do elemento de casca (SHELL43) em conjunto com elemento e barra (BEAM24) pode ser visto na figura 4.13 .

\footnotetext{
${ }^{1}$ Ansys Elements Reference - Release 5.4 (1997)
} 

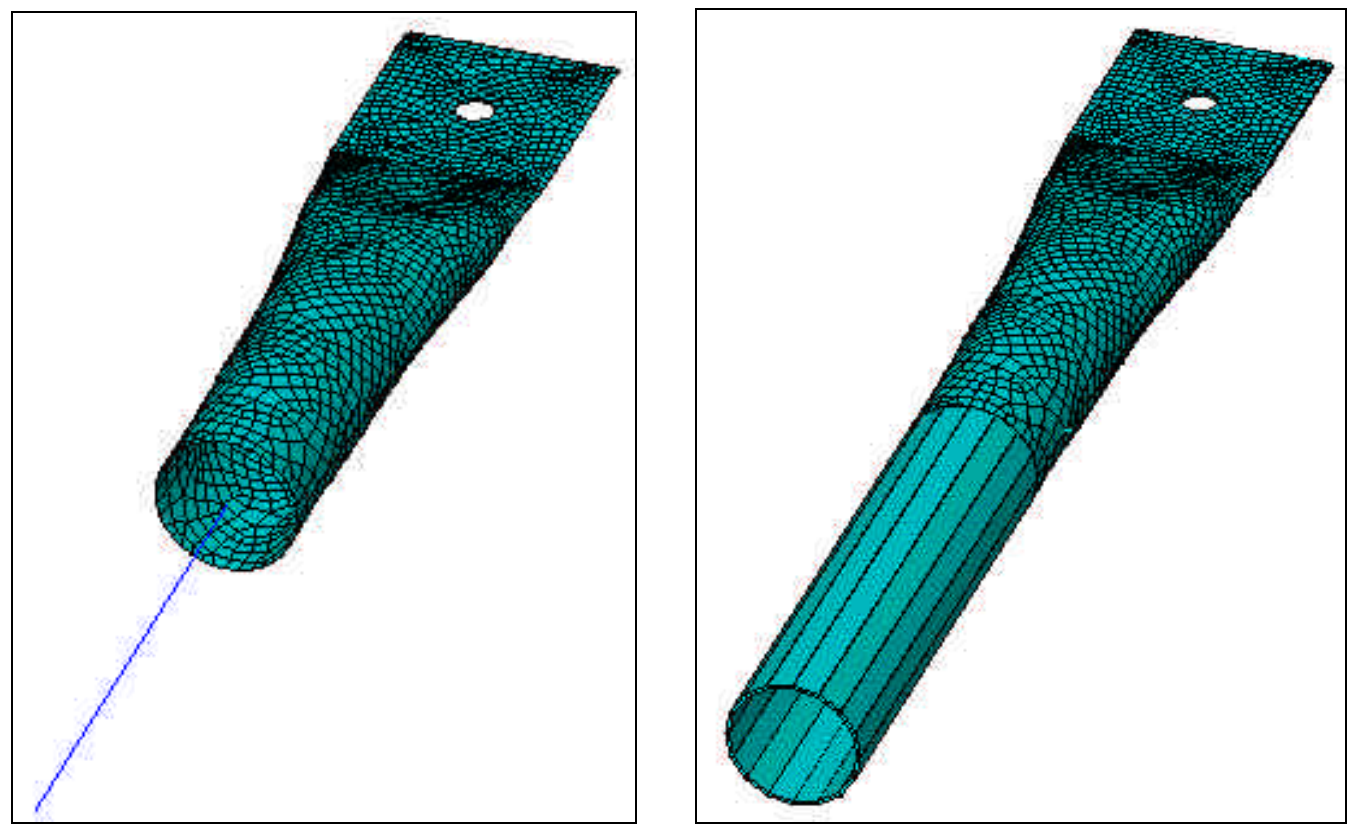

Figura 4.13 - Utilização do SHELL43 com BEAM24

Para a utilização de elementos de barra conjuntamente com elemento de casca, foi necessário fazer um acoplamento entre estes elementos. Neste acoplamento, os nós pertencentes à borda circular das extremidades dos tubos, formado por elementos de casca, foram "escravizados" a um nó mestre, no centro da seção transversal, onde está vinculado o elemento de barra. A figura 4.14 apresenta o detalhe deste acoplamento.
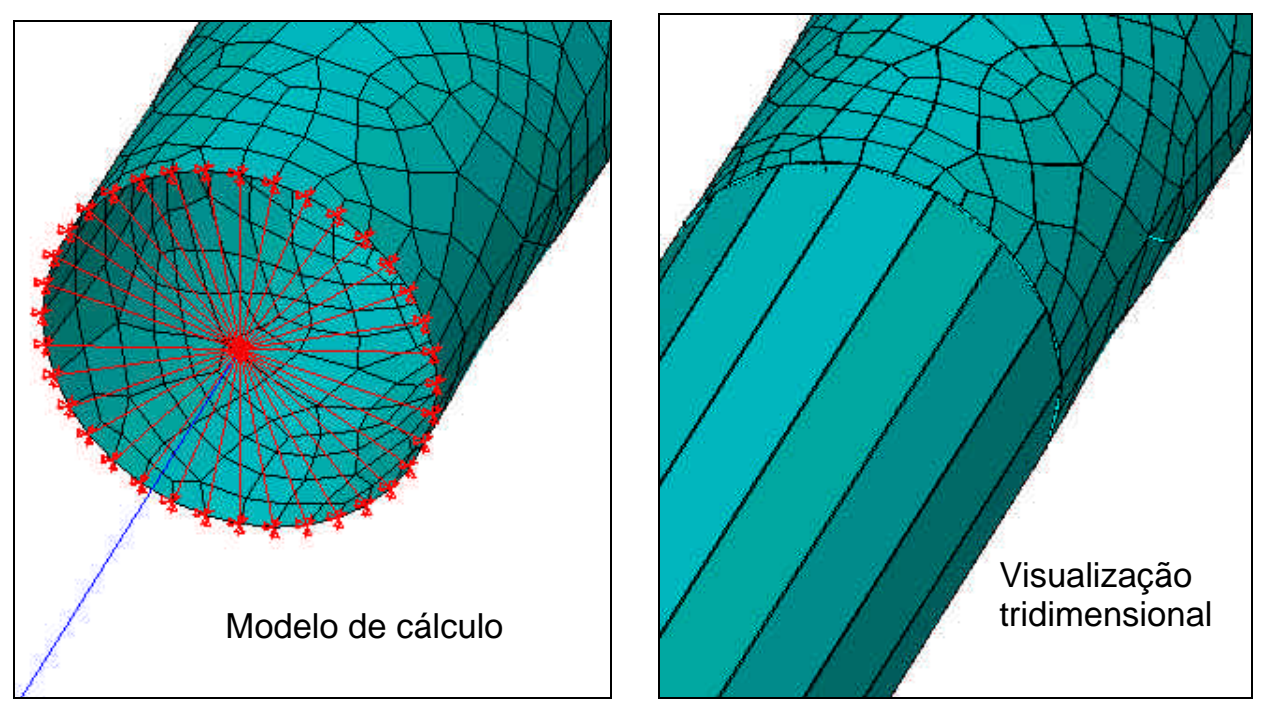

Figura 4.14 - Detalhe da "escravização" dos nós 
Para verificação do acoplamento entre elementos, fez-se uma análise da extremidade do tubo com e sem acoplamento com elemento de barra para uma ação de $50 \mathrm{kN}$. Os resultados das tensões axiais estão ilustrados na figura 4.15 .
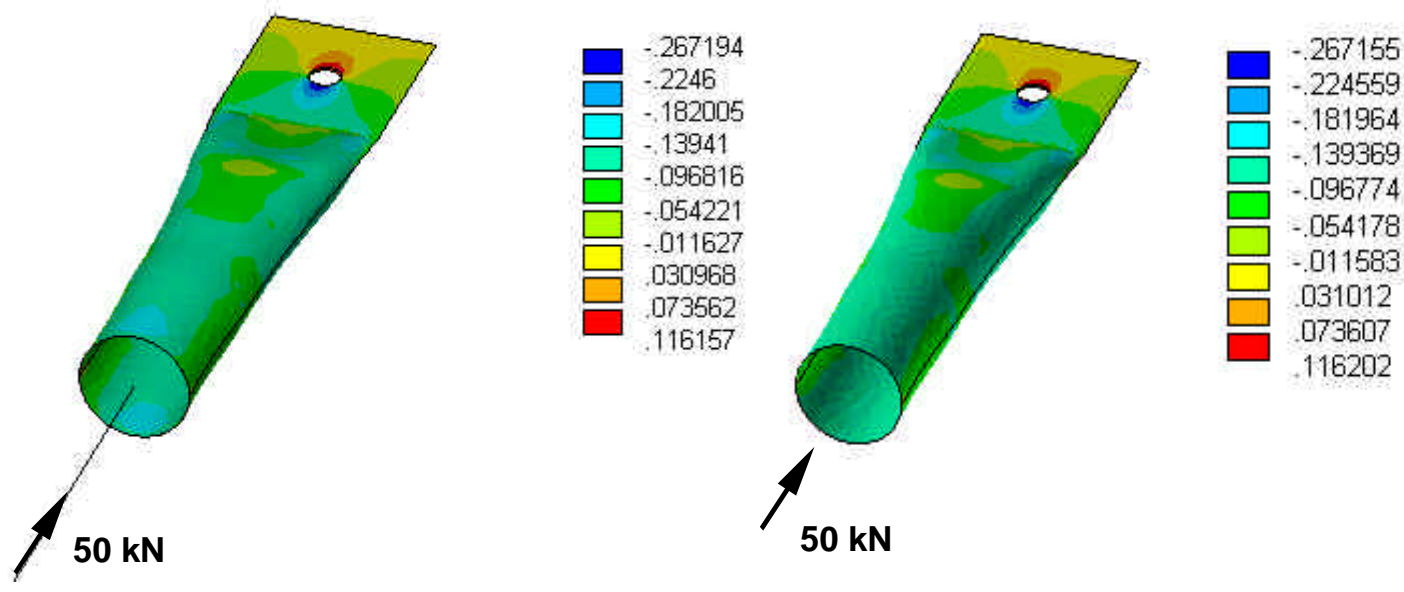

Figura 4.15 - Tensões axiais na extremidade da barra $\left(\mathrm{kN} / \mathrm{mm}^{2}\right)$

Percebe-se pela figura 4.15 a quase coincidência das tensões axiais entre os dois modelos analisados permitindo assim, a utilização do acoplamento.

\section{5- Critérios para análise não linear}

\subsection{1- Não linearidade geométrica}

Neste trabalho os modelos são analisados através do programa ANSYS incluindo os efeitos de não-linearidade geométrica. A formulação adotada pelo programa é a Langrangeana Total e o processo iterativo que 0 programa utiliza para a solução do sistema de equações de equilíbrio é o Newton-Raphson, onde cada iteração gerada no processo é conhecida como uma iteração de Newton-Raphson, ou uma iteração de equilíbrio. 
Salienta-se que para o protótipo em estudo, não há influência desta análise, porém para estruturas de grandes dimensões é recomendável o cálculo considerando a não-linearidade geométrica.

\subsection{2- Não linearidade física}

Adotou-se um modelo bi-linear para representar a curva tensãodeformação do material, tanto na tração quanto na compressão. Este modelo, existente no programa ANSYS, é denominado Classical Bilinear Kinematic Hardening (BKIN) e definido por dois segmentos de retas, onde 0 primeiro, de inclinação maior, representa o comportamento elástico e o segundo, com inclinação menor, representa o comportamento plástico.

As constantes requeridas são a tensão de escoamento $\left(f_{v}\right), 0$ módulo de elasticidade $(E)$ definido para material isotrópico, e o módulo elastoplástico tangente ( $E_{T}$ ) que não pode ser negativo e nem maior do que o módulo elástico $(E)$.

A figura 4.16 apresenta um exemplo da curva bi-linear utilizada para representar o material utilizado em nossa análise.

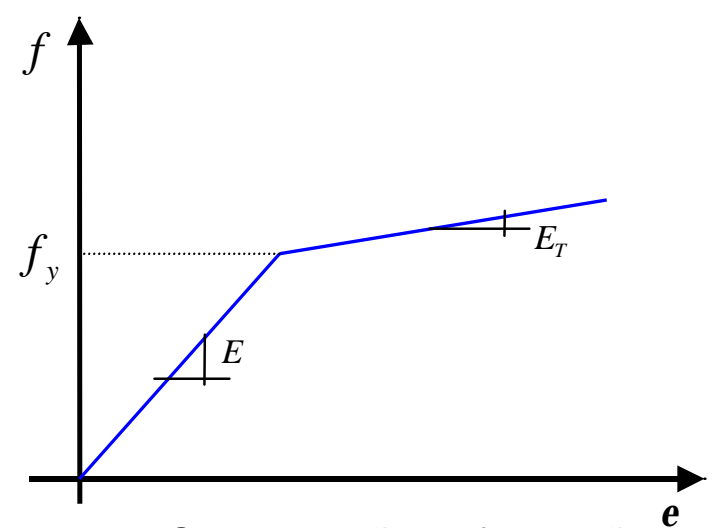

$$
\begin{aligned}
& f_{y}=35 \mathrm{kN} / \mathrm{cm}^{2} \\
& \mathrm{E}=20500 \mathrm{kN} / \mathrm{cm}^{2} \\
& \mathrm{E}_{\mathrm{T}}=2050 \mathrm{kN} / \mathrm{cm}^{2}
\end{aligned}
$$

Figura 4.16 - Curva tensão-deformação do material

Os valores apresentados na figura 4.16 referem-se ao ensaio de caracterização do aço realizado segundo a ASTM - A370/92. 


\section{6- Apresentação dos modelos analisados e resultados}

\subsection{1- Construção dos modelos}

Tendo-se a extremidade da barra modelada com elemento de casca, foi possível modelar o nó como um todo, ou seja, várias extremidades de barras sobrepostas formando o nó típico como ilustra a figura 4.17.
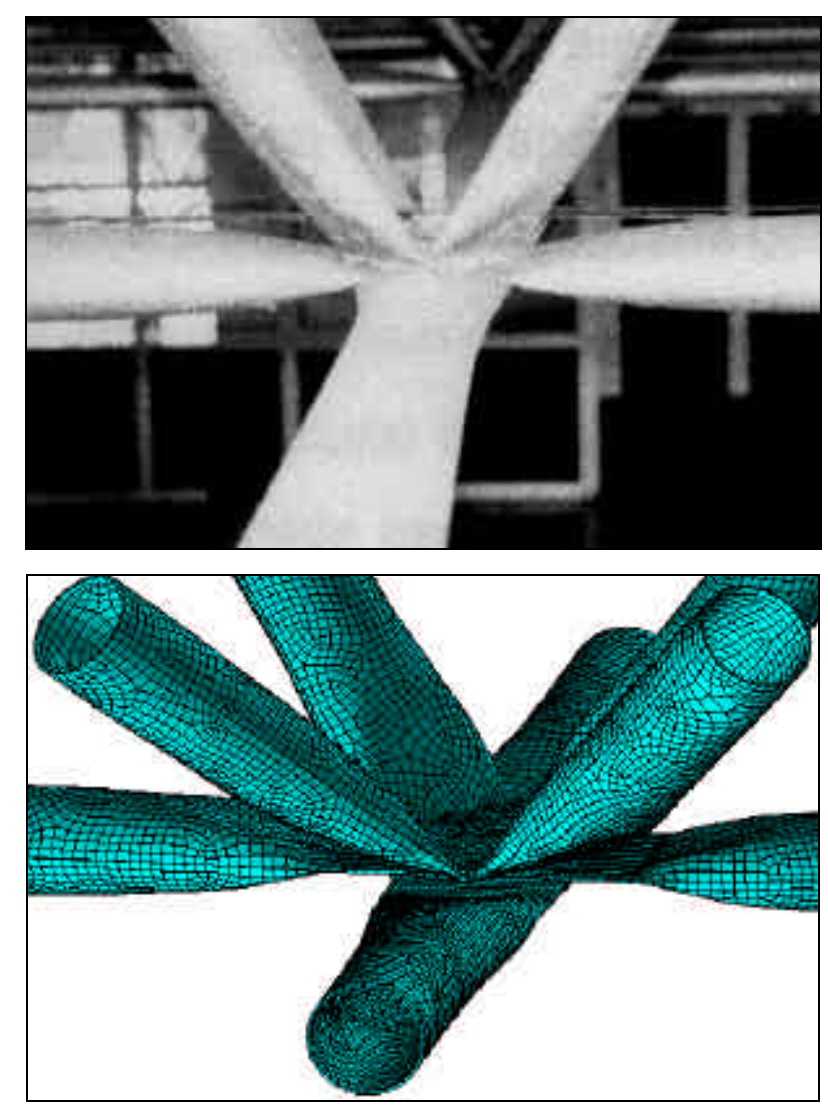

Figura 4.17 - Modelagem do nó típico completo

A região de sobreposição das extremidades das barras foi transformada em um "pacote rígido" , para representar o sistema de ligação formado pelo parafuso e chapa de pressão. Um detalhe desta região esta ilustrado na figura 4.18.

\footnotetext{
1 "Pacote rígido" : Todos os nós nesta região estão acoplados uns aos outros para desenvolverem o mesmo descolamento.
} 


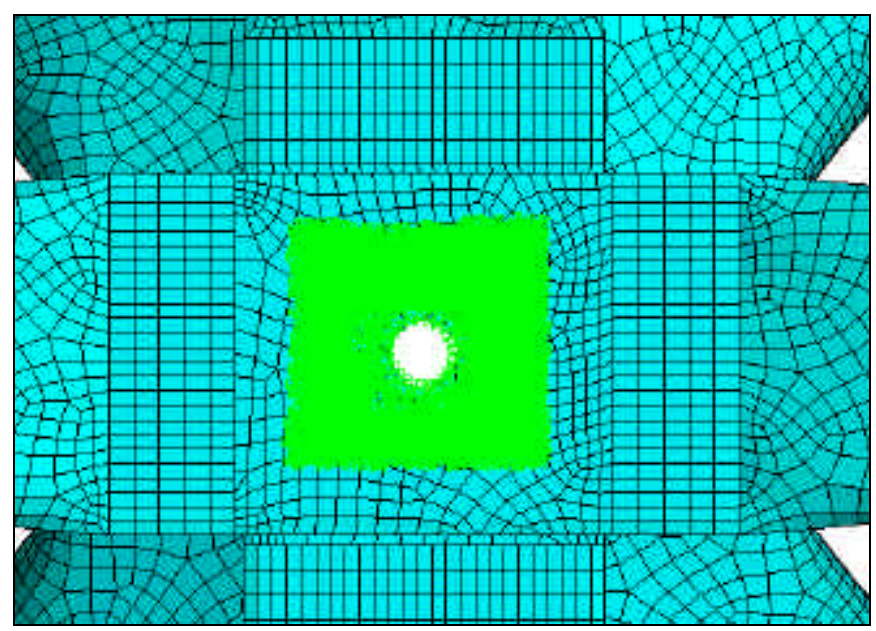

Figura 4.18 - Região transformada em "pacote rígido"

Esta consideração tem como objetivo simplificar a análise nesta região, uma vez que o modelo não considera o deslizamento relativo entre as extremidades e, consequentemente, o atrito entre as superfícies em contato.

Outra simplificação adotada nos modelos, refere-se a pressão causada pelo parafuso, também desprezada nas análises ${ }^{1}$.

Para simular o comportamento deste nó, o mesmo foi inserido em um modelo que representa o protótipo ensaiado no laboratório de Engenharia de Estruturas da EESC-USP, já descrito anteriormente.

Devido as limitações da versão do programa ANSYS existente no Departamento de Engenharia de Estruturas da EESC-USP, introduziu-se apenas um nó completo, modelado com elemento de casca, de cada vez na estrutura, sendo o restante da estrutura modelada com o elemento de barra (BEAM24).

A figura 4.19 apresenta o modelo completo analisado através do programa ANSYS sendo que as barras são compostas do BEAM24 e os nós, simulado com elemento de casca, foram introduzidos no nó central (1), nó lateral (2) e nó de extremidade (3), individualmente para cada modelo analisado.

\footnotetext{
${ }^{1}$ As considerações de deslizamentos relativo, contato e protensão do parafuso será objeto de estudo na continuidade deste trabalho, possivelmente objeto de Tese de Doutorado.
} 


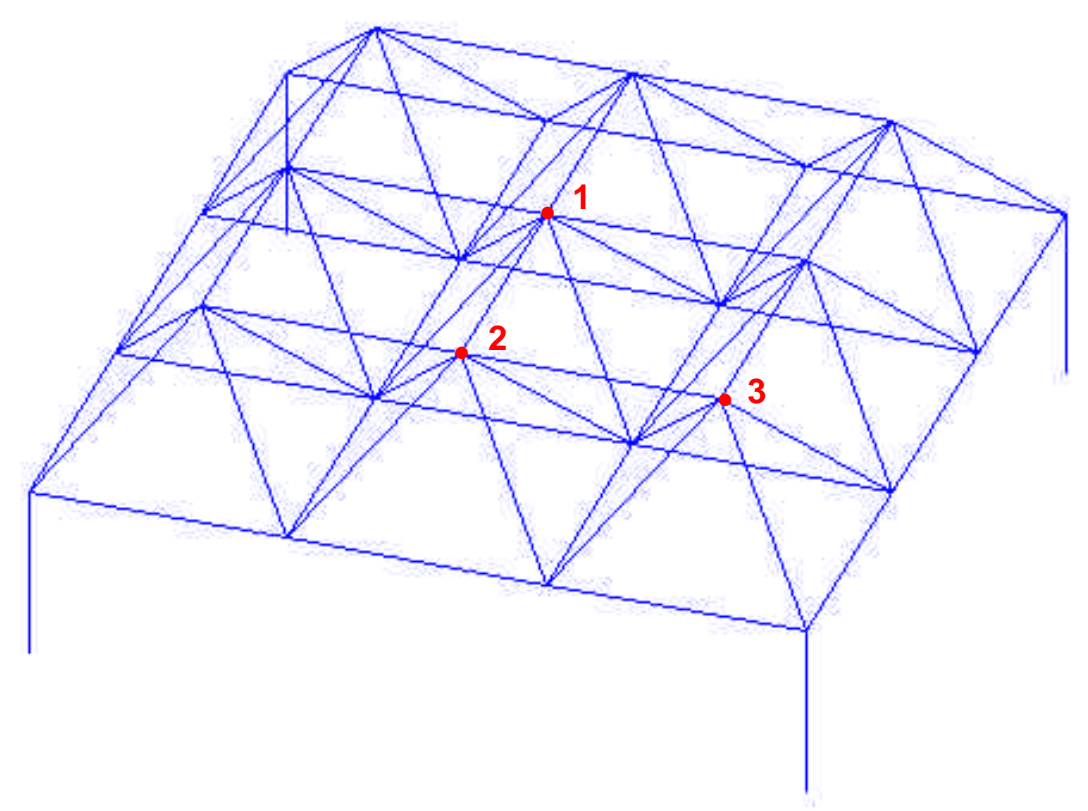

Figura 4.19 - Posições dos nós com elementos de casca

\subsection{2- Modelos analisados}

a) Primeiro modelo - Nó central (1)

Neste modelo, o nó completo foi inserido na região central do banzo superior da treliça, onde temos o encontro dos eixos de simetria da estrutura. A figura 4.20 apresenta o detalhe deste modelo. 

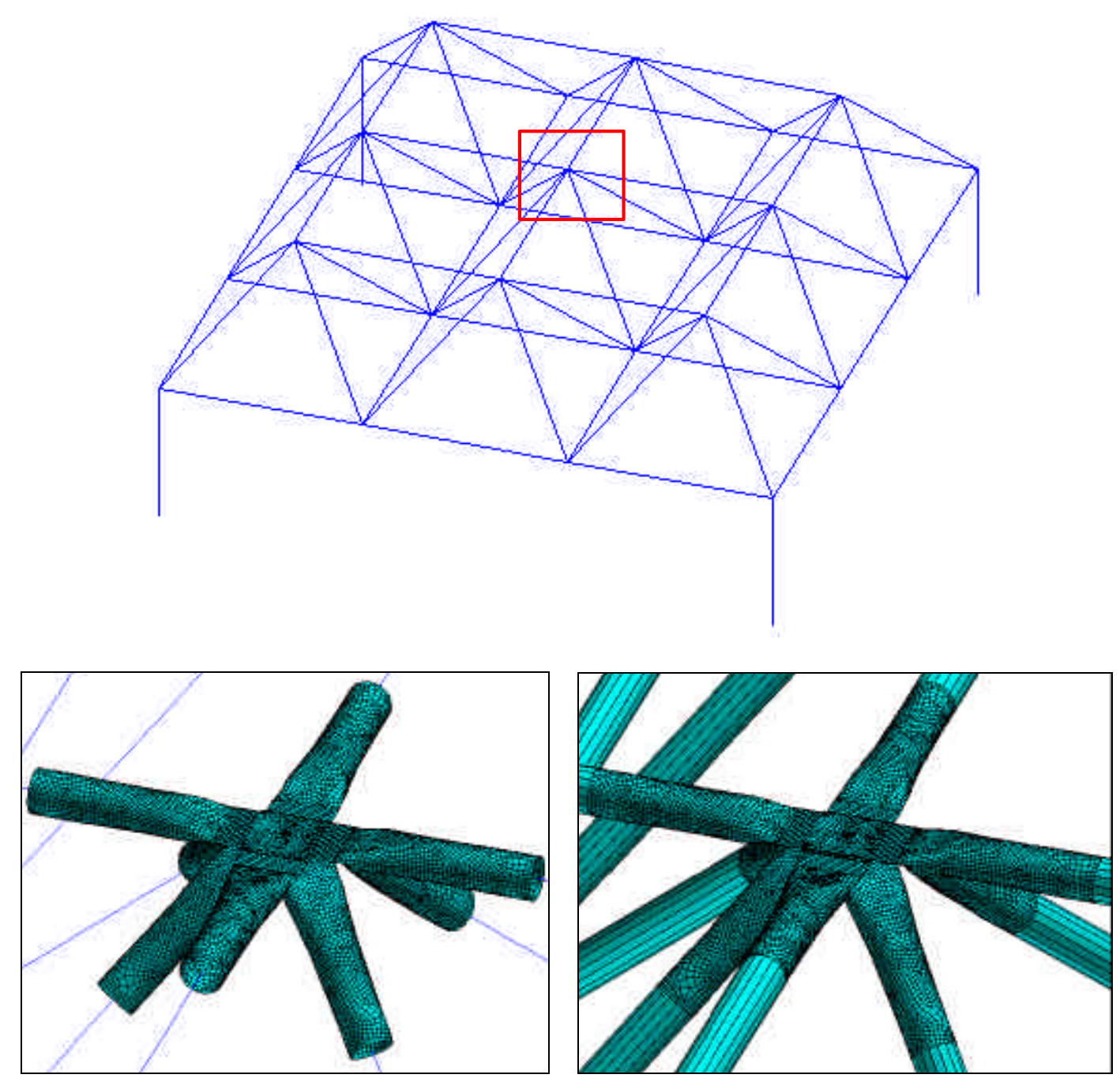

Figura 4.20 - Detalhe da posição do nó típico inserido na estrutura

O gráfico da figura 4.21 apresenta os resultados dos deslocamentos verticais do nó central da treliça com e sem utilização do nó típico modelado com elemento de casca. 


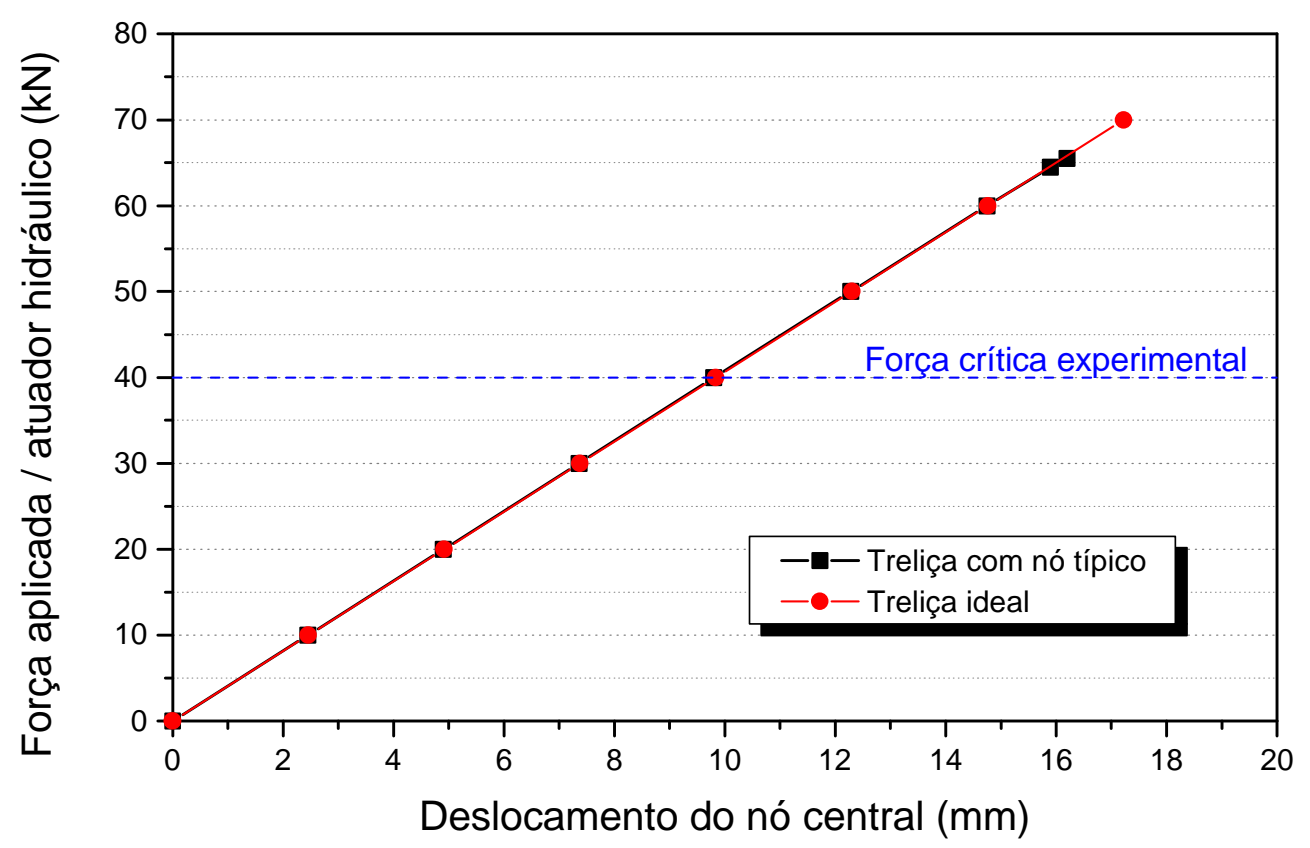

Figura 4.21 - Deslocamento vertical do nó central da treliça

Observa-se que há uma concordância entre os resultados da análise com o nó típico inserido na estrutura e como treliça ideal, ambos mantendo um comportamento linear.

Este fato pode ser compreendido já que apenas um nó típico, modelado com elemento de casca, foi inserido no modelo, sendo o restante da estrutura considerada como treliça ideal. Sendo assim, a carga crítica da estrutura é alcançada devido a problemas localizados no nó modelado com elemento de casca inserido na estrutura, não alterando, portanto, o comportamento global da mesma. Salienta-se que no modelo ensaiado no Laboratório de Estruturas o nó que conduziu a estrutura ao colapso foi o de extremidade (Terceiro modelo - nó extremidade).

Ressalta-se também que o modo de colapso do nó é influenciado pela presença da força cortante nas diagonais que, para este nó específico é nula.

Os resultados da simulação numérica são apresentados pela distribuição das tensões na direção axial das barras cuja força 
correspondente encontra-se indicada sobre a mesma, para várias etapas de carregamento. As figuras $4.22 \mathrm{a}$ a $4.22 \mathrm{f}$ apresentam as tensões axiais $\left(\mathrm{kN} / \mathrm{mm}^{2}\right)$ para os tubos analisados.

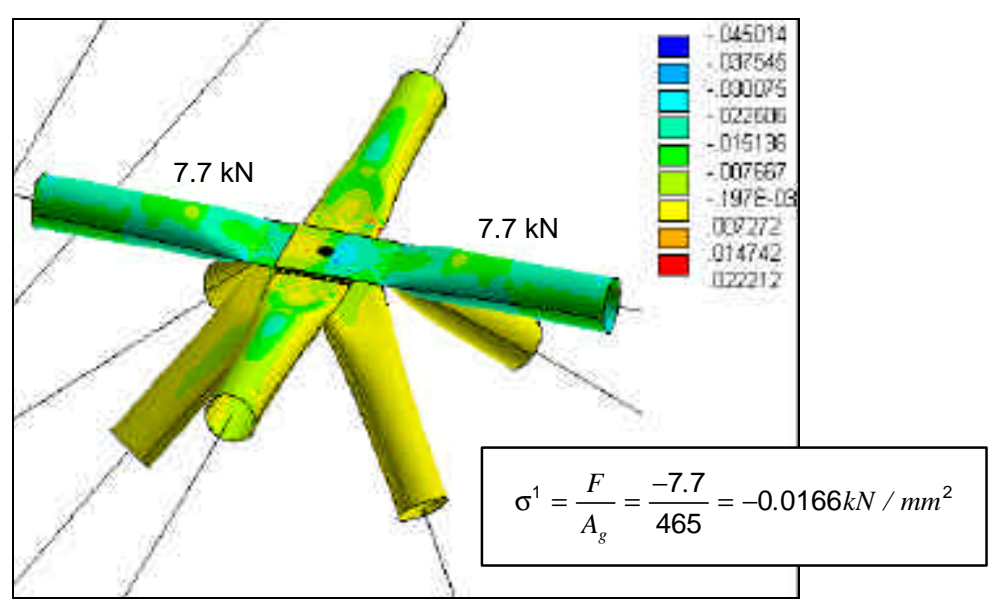

a) Força total aplicada $=40 \mathrm{kN}\left(\text { Tensões em } \mathrm{kN} / \mathrm{mm}^{2}\right)^{1}$

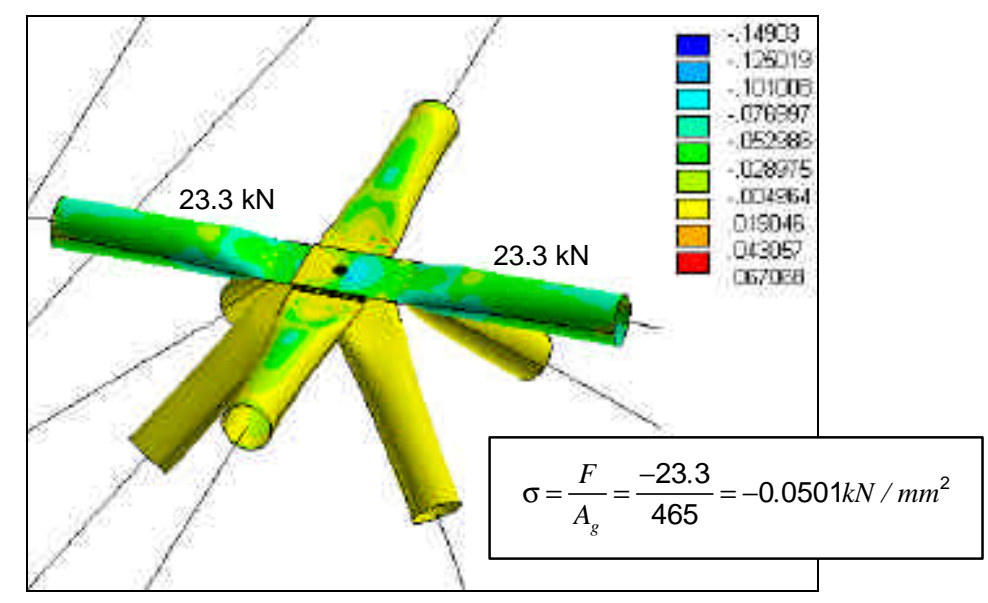

b) Força total aplicada $=120 \mathrm{kN}$ (Tensões em $\mathrm{kN} / \mathrm{mm}^{2}$ )

\footnotetext{
${ }^{1}$ A tensão $\sigma$ representa simplesmente um indicativo da tensão média (Força sobre Área) na barra indicada.
} 


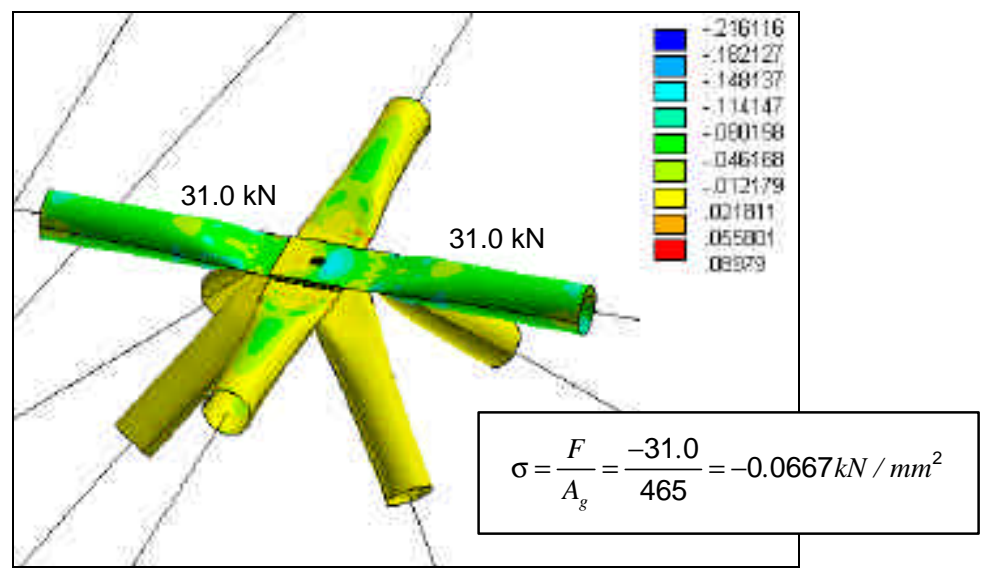

c) Força total aplicada $=160 \mathrm{kN}$ (Tensões em kN/mm²)

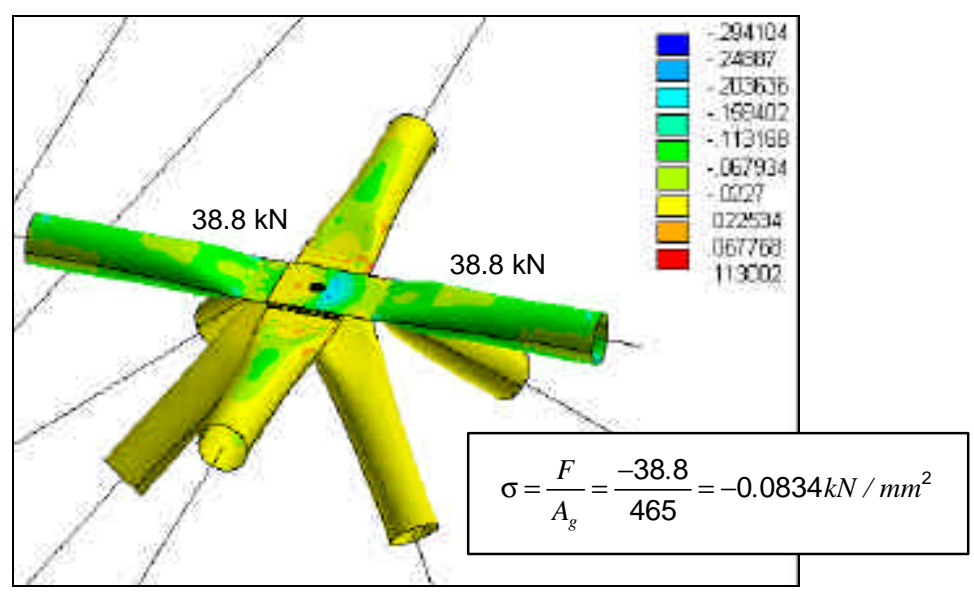

d) Força total aplicada $=200 \mathrm{kN}$ (Tensões em kN/mm²)

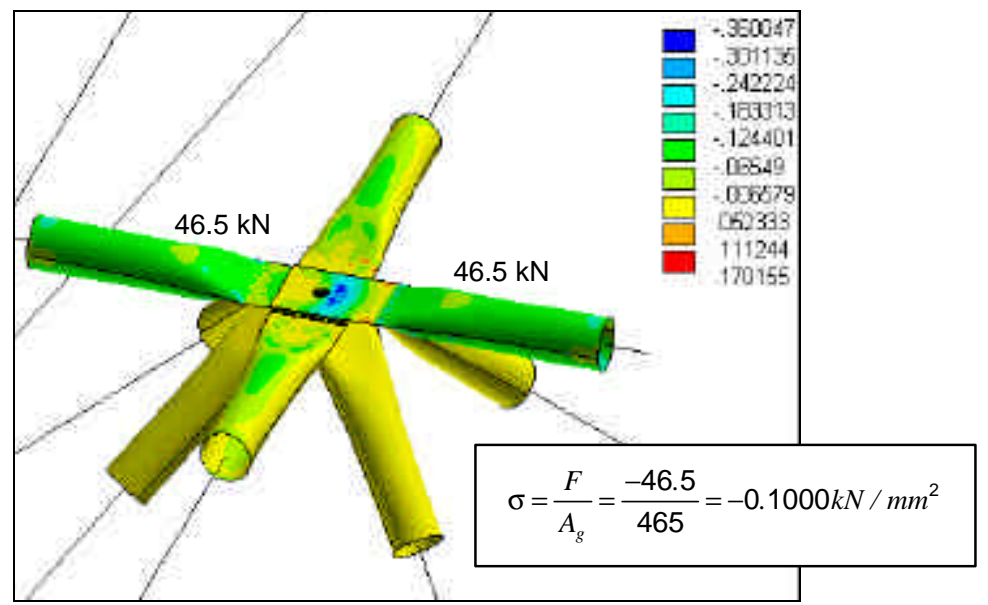

e) Força total aplicada $=240 \mathrm{kN}$ (Tensões em kN/mm²) 


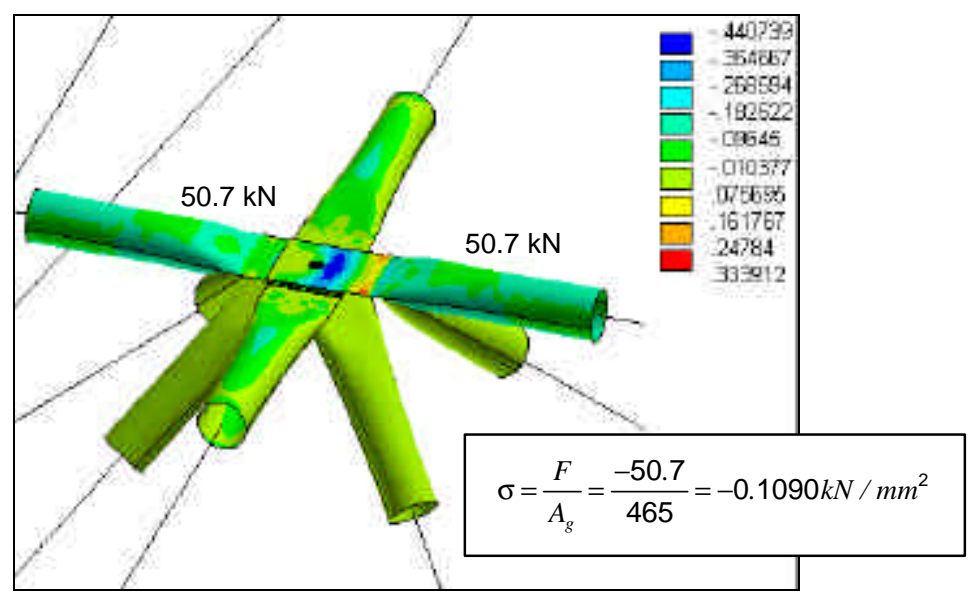

f) Força total aplicada $=262 \mathrm{kN}$ (Tensões em kN/mm²)

Figura 4.22 - Tensões para várias etapas de carregamento $\left(\mathrm{kN} / \mathrm{mm}^{2}\right)$

O valor elevado da carga crítica obtido numericamente, deve-se as condições particulares deste nó, posição de dupla simetria na estrutura, o que não implica em grandes rotações nesta região não ocasionando a ruptura precoce do modelo pela plastificação da extremidade da barra.

As tensões na direção axial das duas barras do banzo analisadas $\left(\sigma=-0.109 \mathrm{kN} / \mathrm{mm}^{2}\right)$, indicam que não ocorre a plastificação da seção central da barra $\left(f_{y}=-0.35 \mathrm{kN} / \mathrm{mm}^{2}\right)$ porém, a força total aplicada de $262.0 \mathrm{kN}$ correspondeu a carga crítica da estrutura na simulação numérica.

Este fato corrobora com as afirmações anteriores de que a ruína da estrutura, que no caso da análise numérica corresponde à carga crítica, é dependente do comportamento do nó.

A figura 4.23 apresenta as tensões axiais da barra do banzo superior para a carga última encontrada na análise numérica (65.5 kN / atuador hidráulico). 


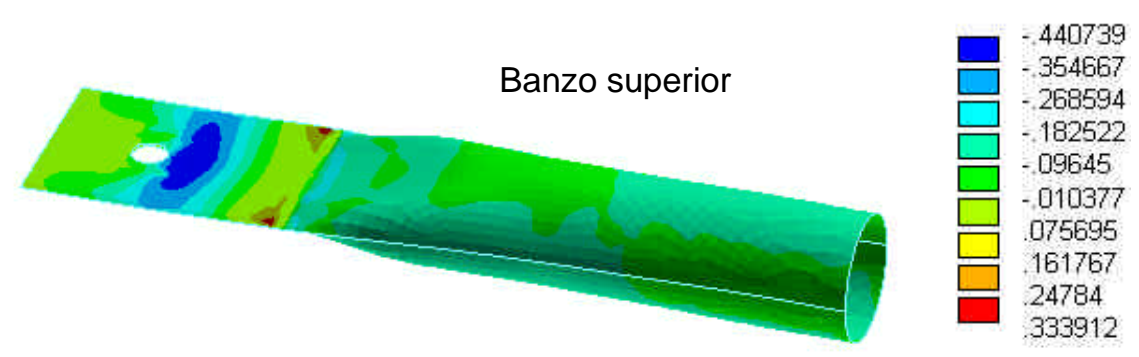

Figura 4.23 - Tensões axiais $\left(\mathrm{kN} / \mathrm{mm}^{2}\right)$ da extremidade da barra para carga última obtida numericamente.

Percebe-se pela figura 4.23 a concentração de tensões de compressão na região próxima a borda do parafuso. Tensões essas superiores a do limite de escoamento do aço $\left(f_{y}=-0.35 \mathrm{kN} / \mathrm{mm}^{2}\right)$ e que conduziram à determinação da máxima força aplicada na estrutura.

b) Segundo modelo - Nó lateral (2)

Neste modelo, o nó completo foi inserido na região de extremidade do banzo superior da treliça, como apresenta a figura 4.24.

Diferentemente do nó central, neste caso não há a dupla simetria e é possível avaliar a influência da força cortante atuando nas diagonais. 

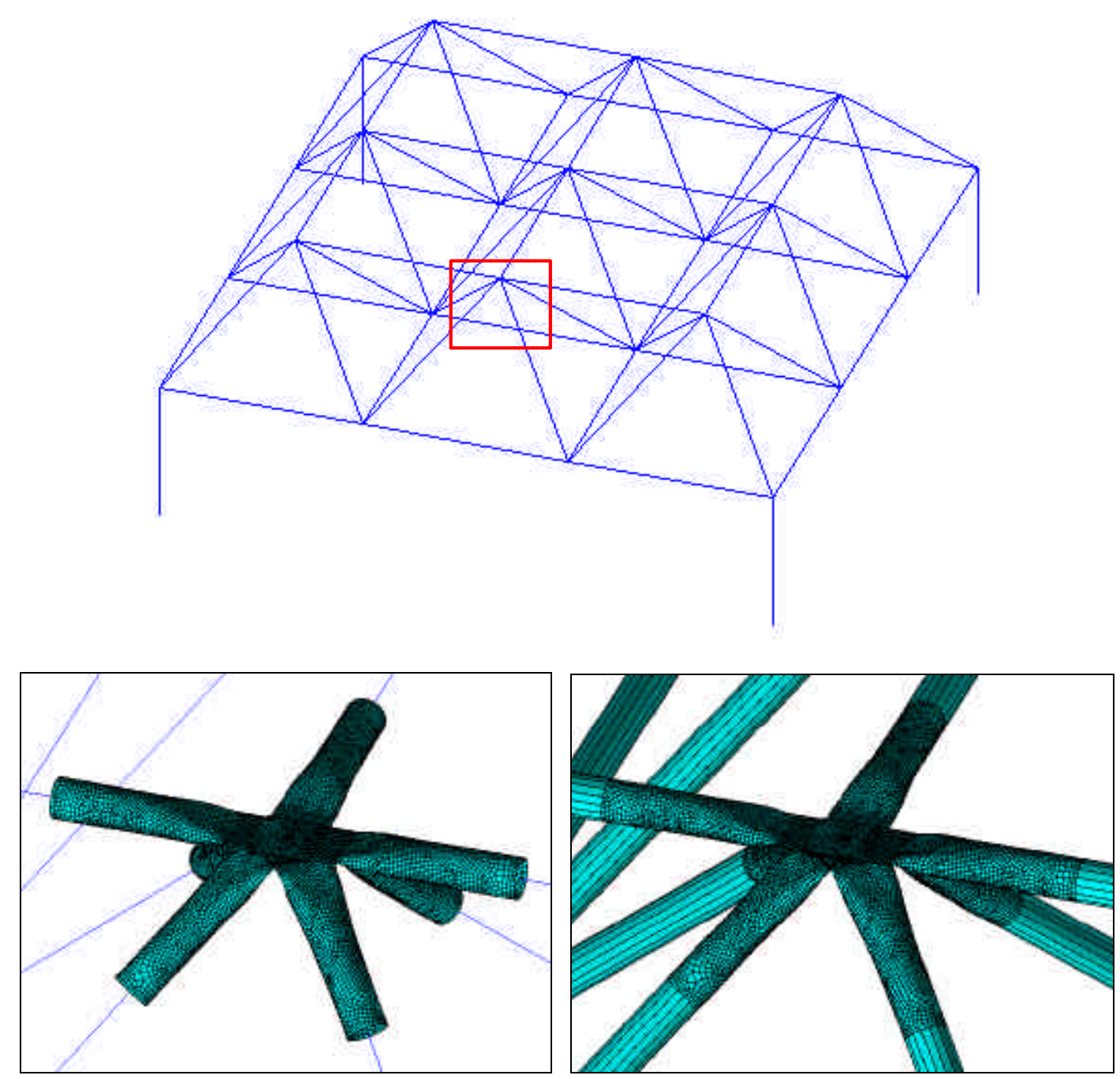

Figura 4.24 - Detalhe da posição do nó inserido na estrutura

O gráfico da figura 4.25 apresenta os resultados dos deslocamentos verticais do nó com elemento de casca, do nó central e do nó simétrico ao nó com elemento de casca. 


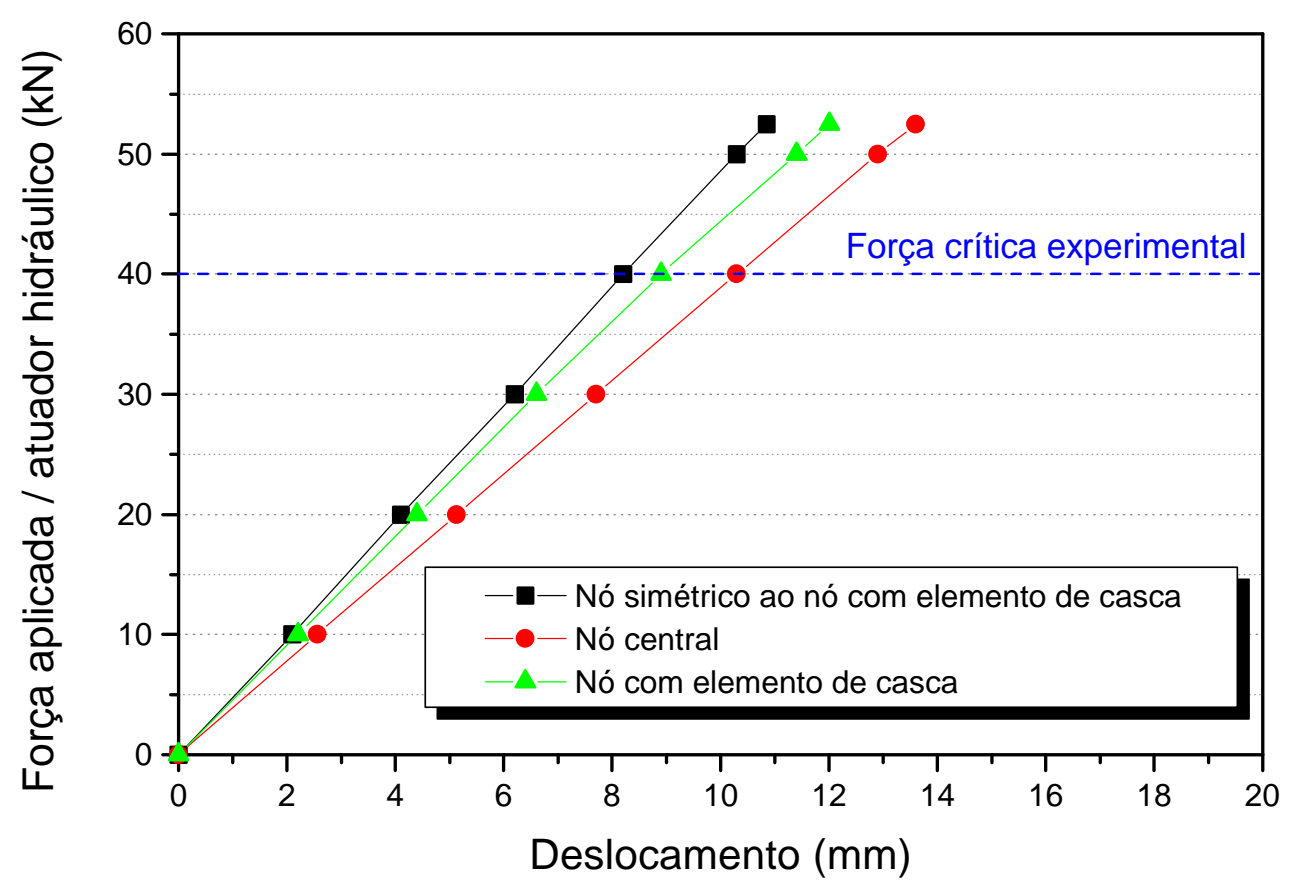

Figura 4.25 - Deslocamento vertical de alguns nós da estrutura

Percebe-se, pela análise dos resultados dos deslocamentos apresentados no gráfico da figura 4.24, que o nó com elemento de casca possui deslocamentos maiores que o nó da posição simétrica na estrutura. Este fato pode ser compreendido já que a região da treliça onde temos o nó com elemento de casca torna-se menos rígida se comparada com a região simétrica na estrutura, uma vez que esta possui características de uma treliça ideal sendo, portanto, mais rígida.

Em vista disto, pode-se afirmar também que, se a região na qual foi inserido o nó típico torna-se menos rígida se comparada com a região simétrica de características iguais a de uma treliça ideal, as análises utilizando as hipóteses de treliça ideal em estruturas que utilizam o sistema de ligação típico, fornecerão resultados não condizentes com o modelo físico. Motivo este que pode ser relevante e conduzir a ruína de várias estruturas, utilizando este sistema de ligação, em nosso país.

Quanto ao deslocamento do nó central, este apresenta valores superiores aos outros dois nós, como deveria ser. 
As figuras 4.26a a 4.26f , apresentam o comportamento em níveis de tensões para várias etapas de carregamento de maneira análoga ao do primeiro modelo - Nó central (1).

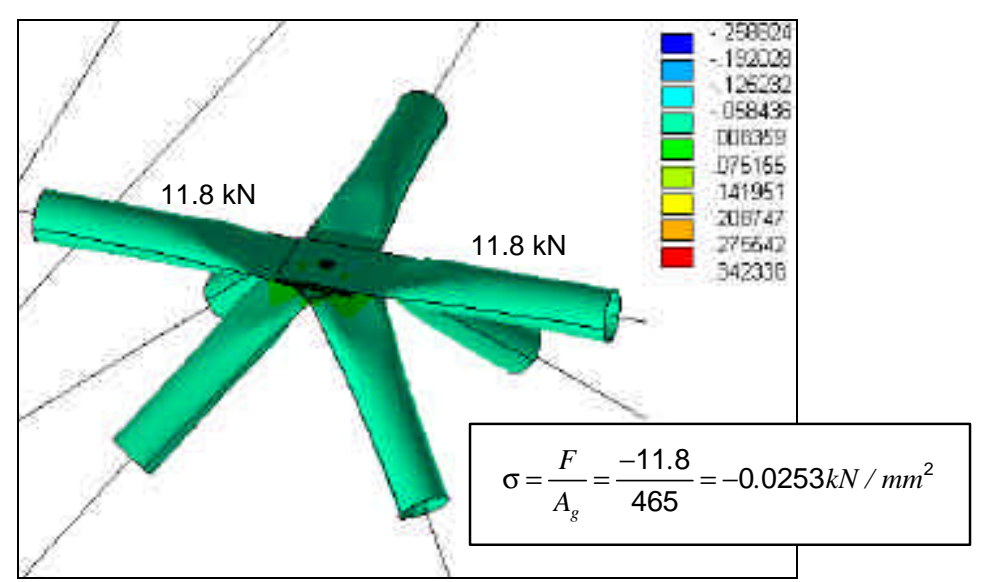

a) Força total aplicada $=40 \mathrm{kN}$ (Tensões em $\mathrm{kN} / \mathrm{mm}^{2}$ )

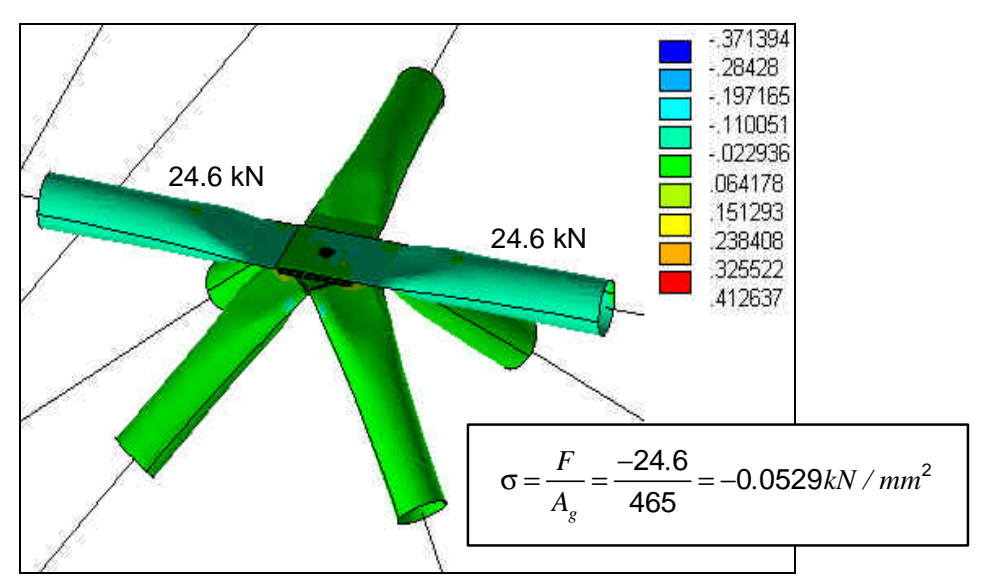

b) Força total aplicada $80 \mathrm{kN}$ (Tensões em kN/mm²) 


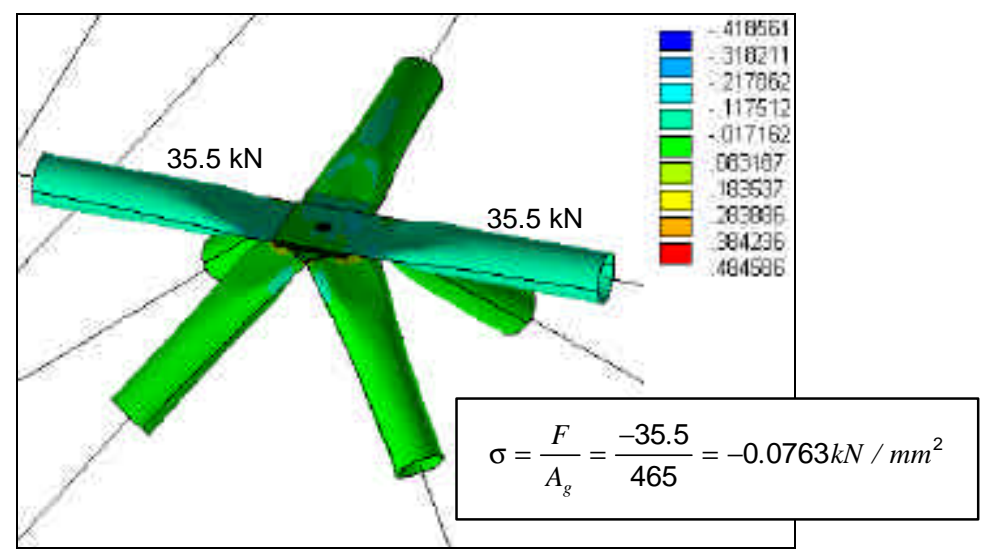

c) Força total aplicada $=120 \mathrm{kN}$ (Tensões em kN/mm²)

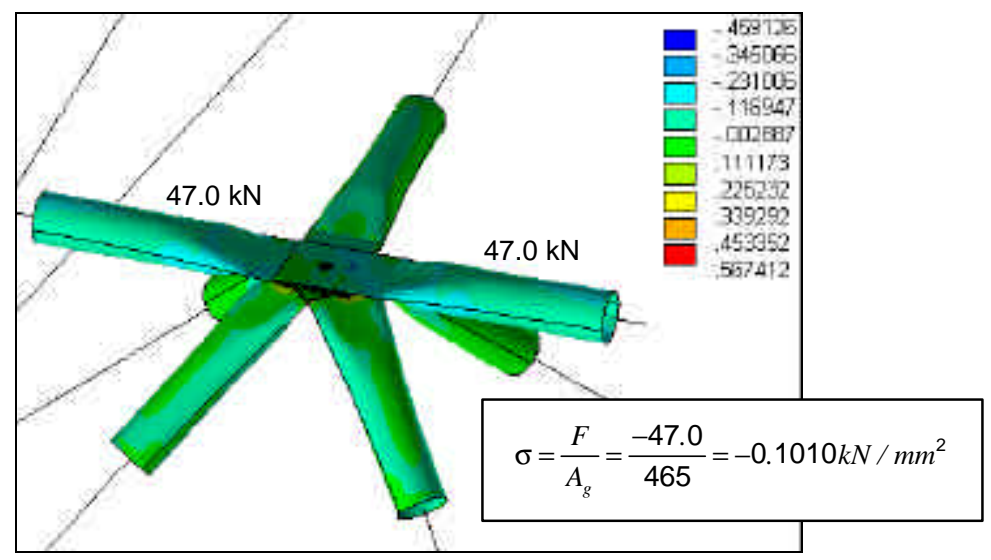

d) Força total aplicada $=160 \mathrm{kN}$ (Tensões em kN/mm²)

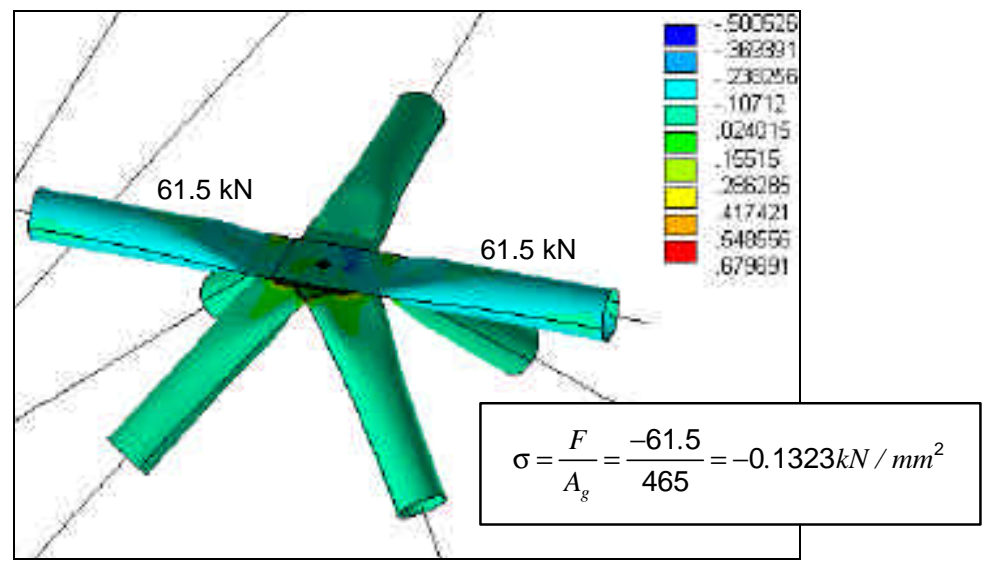

e) Força total aplicada $=200 \mathrm{kN}$ (Tensões em kN/mm²) 


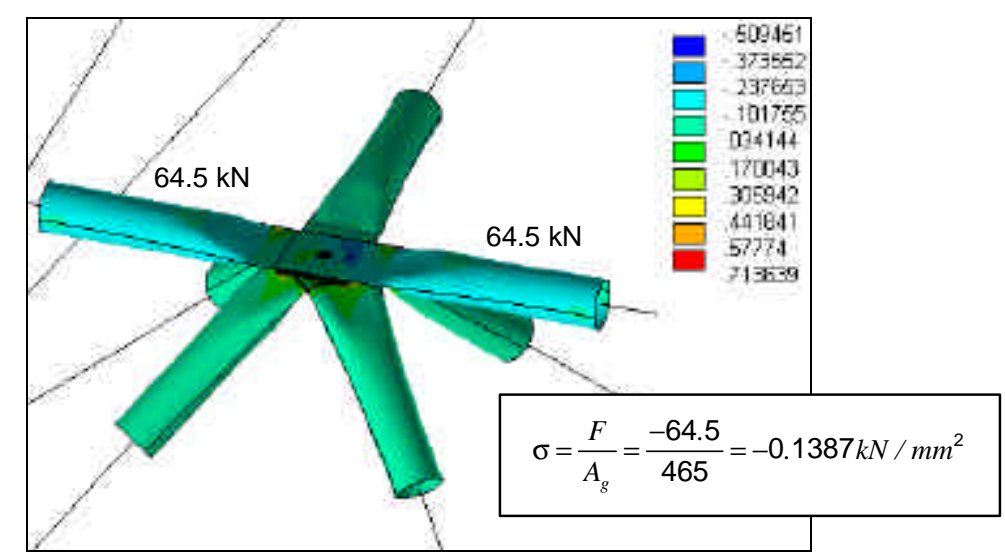

f) Força total aplicada $=210 \mathrm{kN}$ (Tensões em $\mathrm{kN} / \mathrm{mm}^{2}$ )

Figura 4.26 - Tensões para várias etapas de carregamento $\left(\mathrm{kN} / \mathrm{mm}^{2}\right)$

Neste modelo, pelo fato do nó não estar em uma posição de dupla simetria da estrutura, como no primeiro modelo - nó central, temos uma diminuição da carga crítica da estrutura.

Esta diminuição decorre do fato que não temos uma simetria dos esforços nas barras concorrentes ao nó e também devido a influência do esforço cortante nas diagonais causando uma maior rotação do nó, acabando por plastificar a região da extremidade da barra. Na região central da barra o valor da tensão axial $\left(\sigma=-0.138 \mathrm{kN} / \mathrm{mm}^{2}\right)$ fica abaixo do valor de plastificação $\left(f_{y}=-0.35 \mathrm{kN} / \mathrm{mm}^{2}\right)$.

Novamente temos a confirmação das afirmações anteriores que a ruína da estrutura, que na análise numérica corresponde à carga crítica, é dependente do comportamento do nó.

A figura 4.27 apresenta as tensões na diagonal e banzo superior obtida para a carga última encontrada na análise numérica (52.5 kN / atuador hidráulico). 


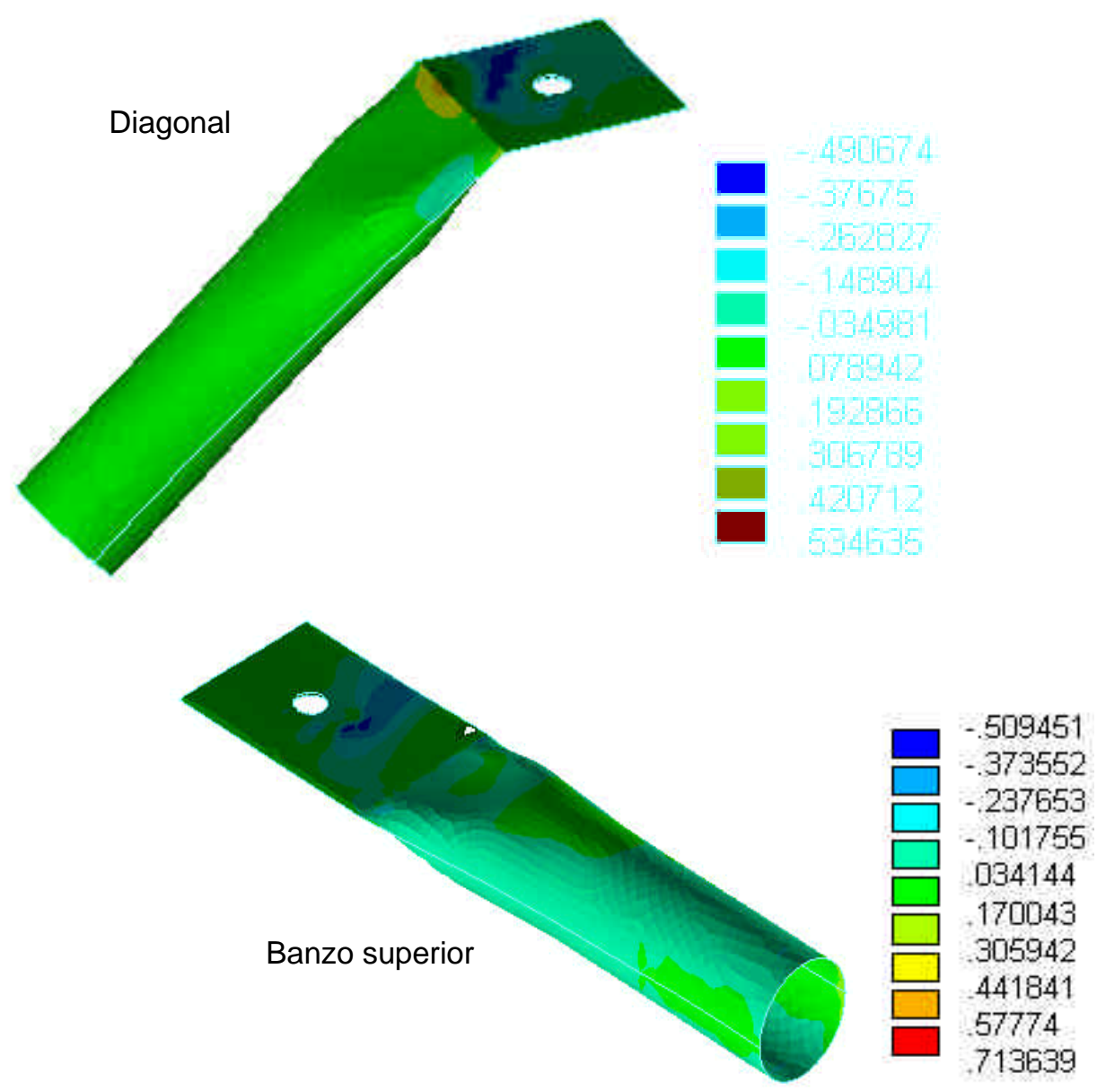

Figura 4.27 - Tensões axiais $\left(\mathrm{kN} / \mathrm{mm}^{2}\right)$ da extremidade da barra para carga última obtida numericamente.

Percebe-se, pela figura 4.27, a elevada concentração de tensões de tração e compressão, acima da tensão de escoamento $\left(\mathrm{f}_{\mathrm{y}}= \pm 0.35 \mathrm{kN} / \mathrm{mm}^{2}\right)$, na região estampada das barras.

c) Terceiro modelo - Nó de extremidade (3)

Neste modelo, o nó completo foi inserido no canto do banzo superior da treliça onde temos uma maior concentração de esforços axiais, principalmente na diagonal de apoio, e também grande rotação do nó, pois a força cortante é transmitida pela diagonal até o apoio. A figura 4.28 mostra o detalhe deste modelo. 

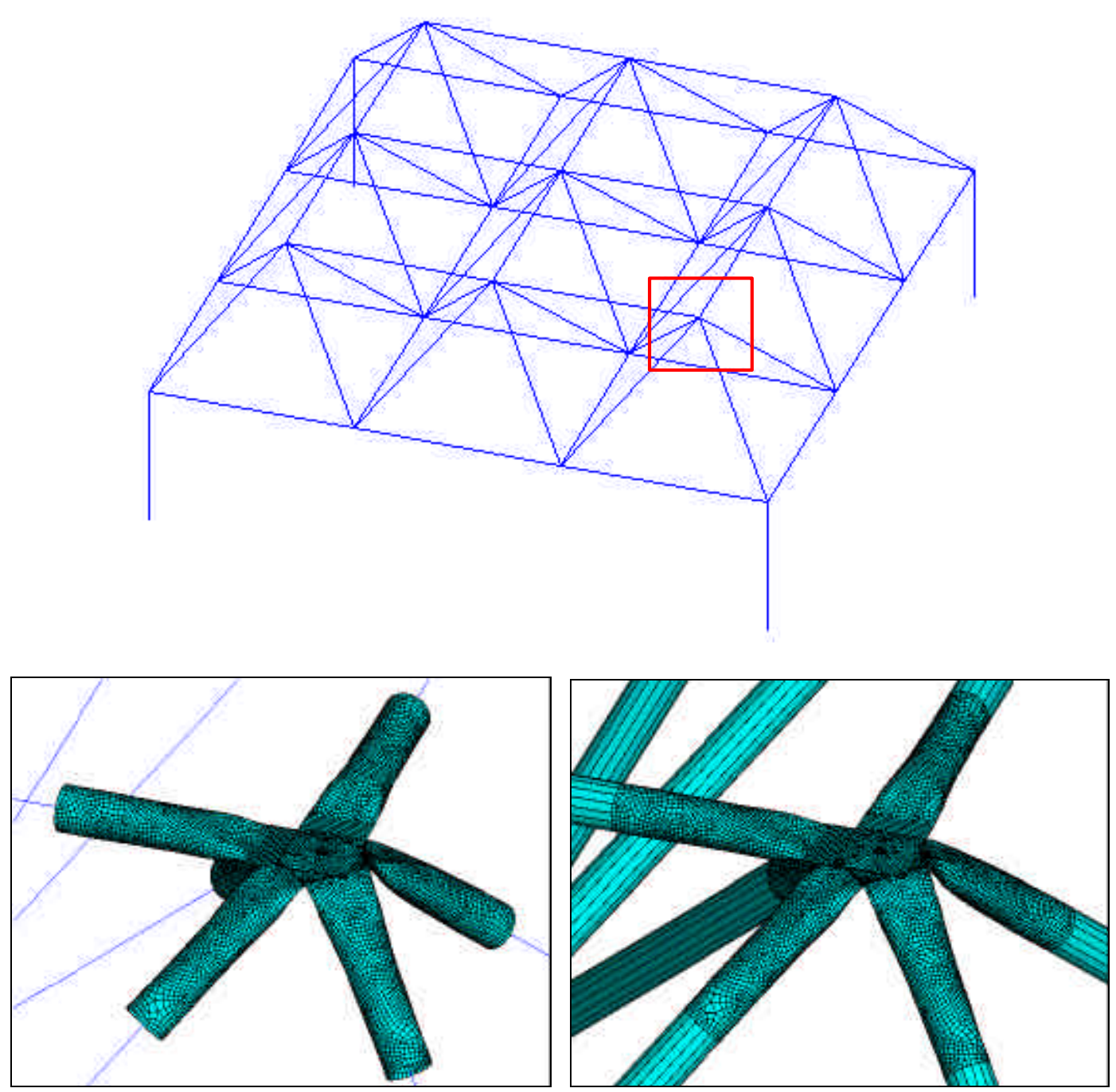

Figura 4.28 - Detalhe da posição do nó inserido na estrutura

O gráfico da figura 4.29 apresenta os resultados dos deslocamentos verticais do nó com elemento de casca, do nó central e do nó simétrico ao nó com elemento de casca. 


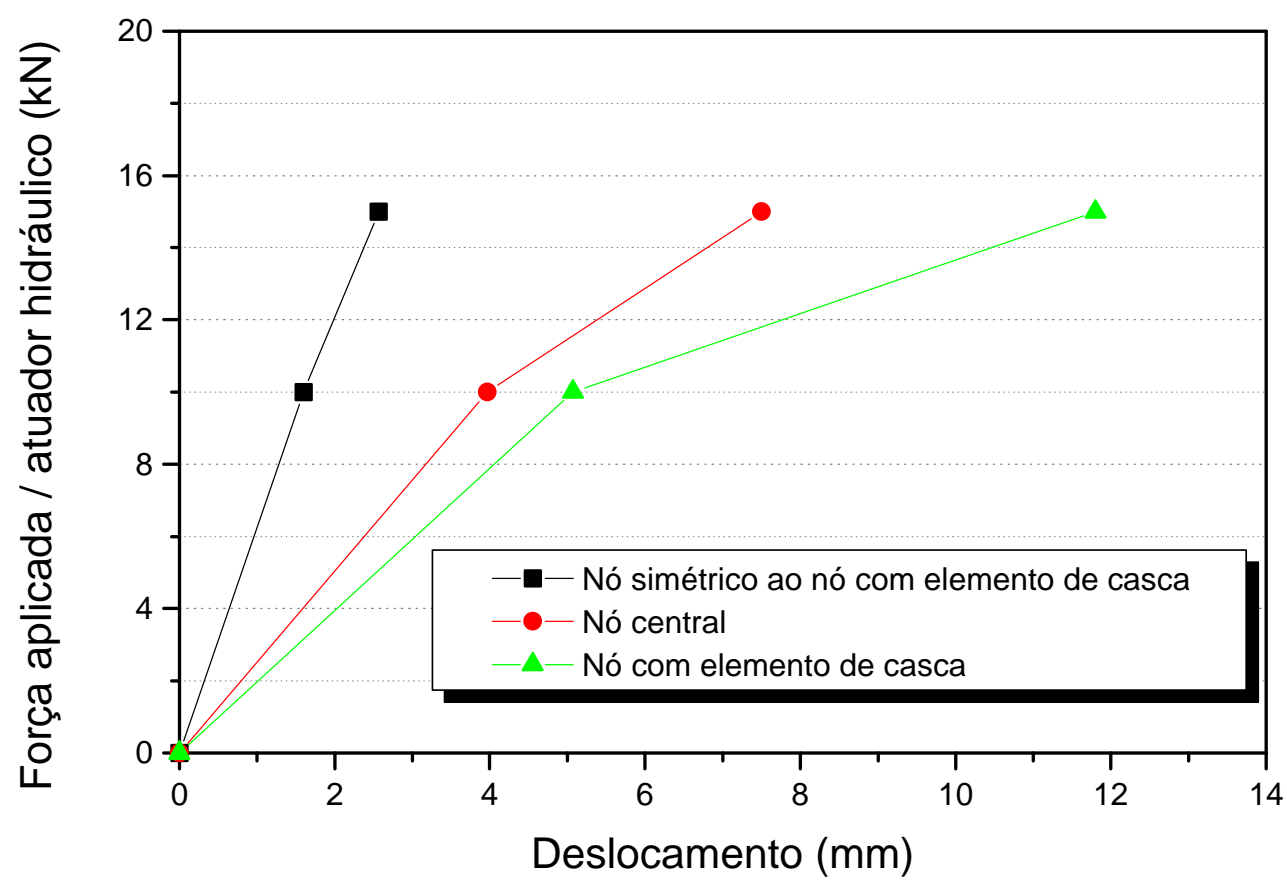

Figura 4.29 - Deslocamento vertical de alguns nós da estrutura

Os resultados dos deslocamentos apresentados no gráfico da figura 4.29 ilustram que o nó de extremidade (nó com elemento de casca) apresenta deslocamentos superiores ao nó simétrico na estrutura e também, ao nó central.

O motivo dos deslocamentos do nó de extremidade serem maiores que do nó central, é a rápida plastificação da diagonal de apoio e dos banzos que concorrem neste nó, devido a transferência de esforços pela diagonal de apoio à coluna, associado à perda de rigidez nesta região devido a inserção do nó típico modelado com elemento de casca.

Comprova-se novamente que, devido a esta perda de rigidez na região com nó típico, as hipóteses de treliça ideal em estruturas que utilizam o sistema de ligação típico, fornecerão resultados não condizentes com o comportamento da estrutura, pois este modelo não é capaz de reproduzir o modo de ruína da estrutura. 
As figuras $4.30 \mathrm{a}$ e $4.30 \mathrm{~b}$, apresentam o comportamento em níveis de tensões para duas etapas de carregamento de maneira análoga aos modelos anteriores.

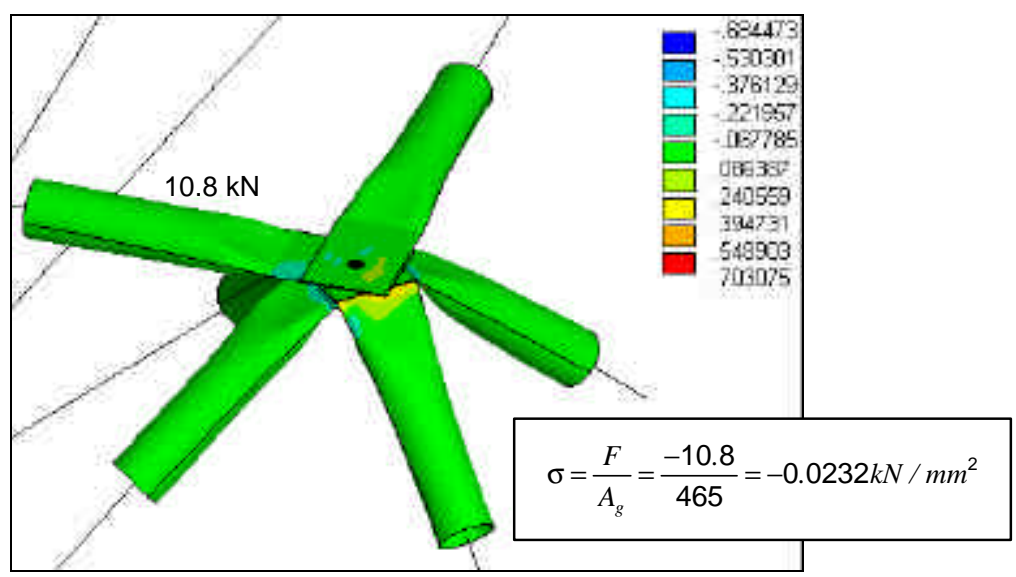

a) Força total aplicada $=40 \mathrm{kN}$ (Tensões em $\mathrm{kN} / \mathrm{mm}^{2}$ )

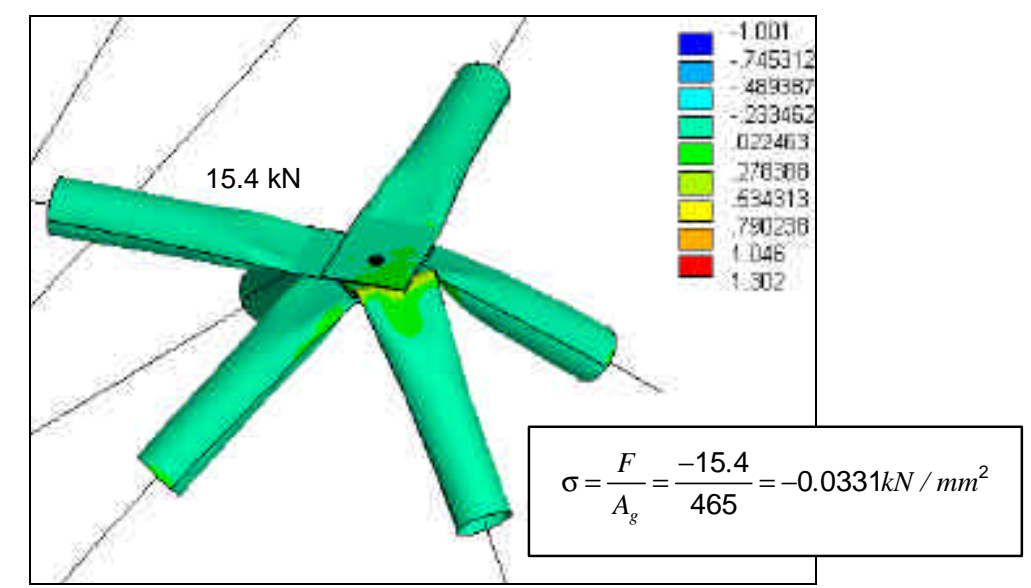

b) Força total aplicada $=60 \mathrm{kN}\left(\right.$ Tensões em $\mathrm{kN} / \mathrm{mm}^{2}$ )

Figura 4.30 - Tensões para várias etapas de carregamento $\left(\mathrm{kN} / \mathrm{mm}^{2}\right)$

Neste modelo, o nó com elemento de casca foi inserido na região de maior solicitação da estrutura, uma vez que os esforços são transferidos para as colunas pela diagonal de apoio que concorre a este nó.

Percebe-se, pela análise das tensões, uma considerável plastificação na diagonal de apoio. Isto ocorre devido à variação de inércia da barra, 
dobramento da extremidade para confecção do nó típico e a rotação excessiva desta região. As figuras 4.31 e 4.32 ilustram o resultado obtido no ensaio e o observado numericamente, para a barra da diagonal de apoio, respectivamente.

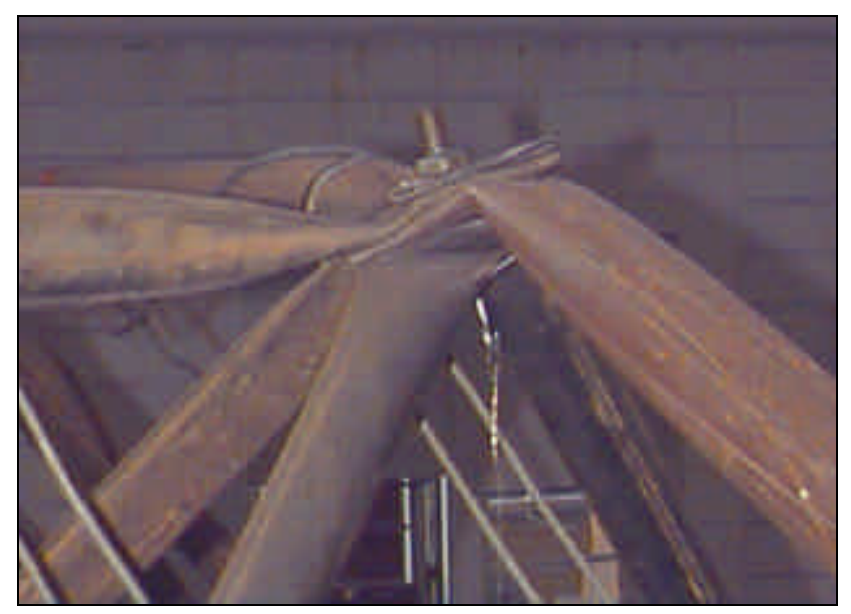

Figura 4.31 - Rotação excessiva e plastificação da região nodal

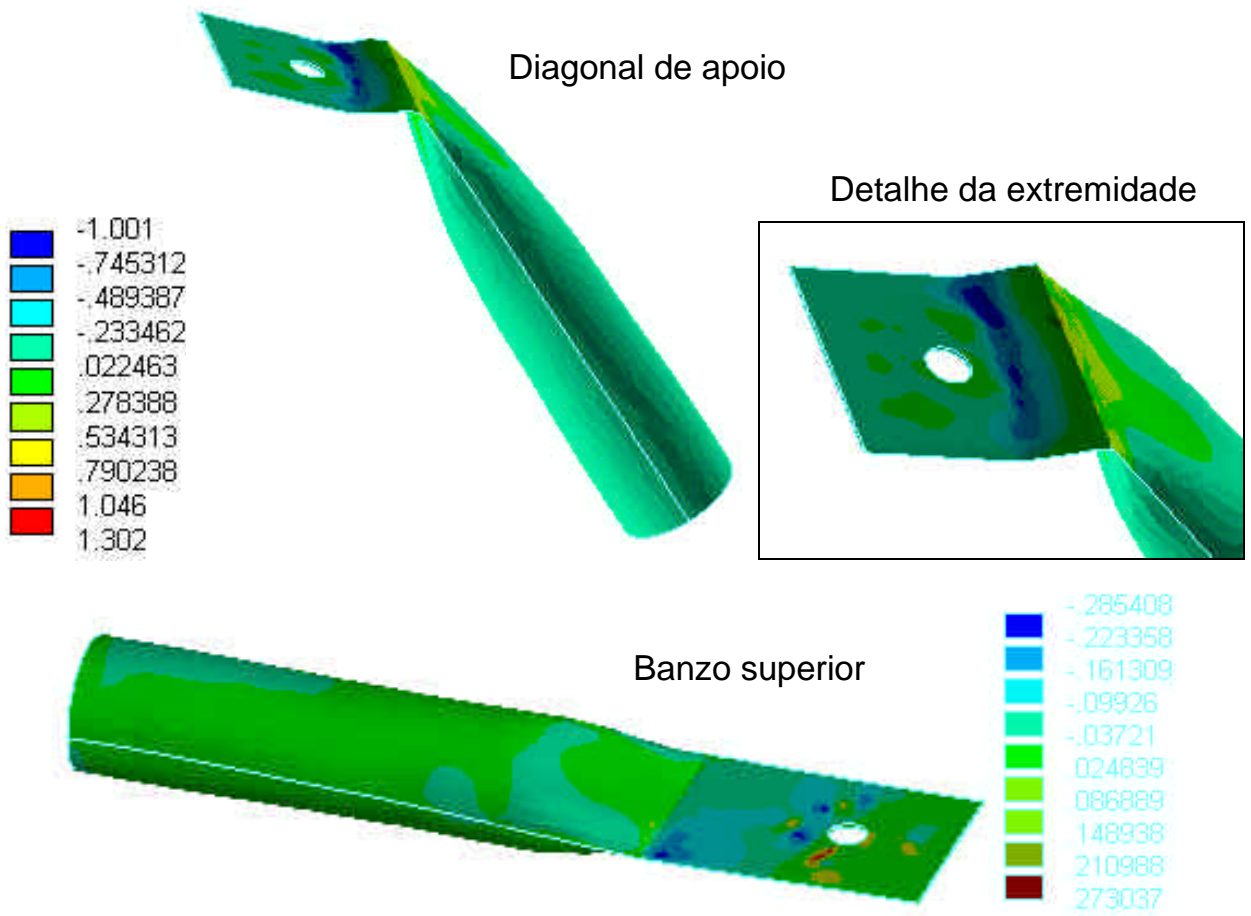

Figura 4.32 -Tensões axiais $\left(\mathrm{kN} / \mathrm{mm}^{2}\right)$ nas extremidade das barras que compõem o nó típico para a carga última obtida numericamente 
Os fatores apresentados tornam esta região bastante crítica, fazendo com que o modo de falha da estrutura, na simulação numérica, ocorra para um carregamento bastante inferior (15.0kN/atuador hidráulico) ao obtido experimentalmente (40.0kN/atuador hidráulico) no ensaio do protótipo.

Justifica-se este fato, pela descrição do comportamento desta região na realização do ensaio. Por ser uma região bastante solicitada da estrutura (diagonal de apoio) e devido aos problemas apresentados (dobramento da extremidade da barra para confecção do sistema de ligação) com baixos valores de carga aplicada, ocorre a plastificação desta região sem, no entanto, conduzir a estrutura à ruína. Na continuidade do ensaio, em função do aumento da carga aplicada, ocorre uma rotação excessiva desta região comprometendo o conjunto, parafuso e chapa de pressão, o que leva a estrutura ao colapso localizado do nó (fig. 4.31).

Para o modelo numérico utilizando o nó típico discretizado com elemento de casca, ainda não foi possível simular o comportamento observado no ensaio. Isto ocorre devido a grande concentração de tensões nesta região, não absorvida pelo modelo numérico, terminando por interromper o processo iterativo da solução não-linear para um nível de carregamento bastante baixo na estrutura (15.0 kN/atuador hidráulico) se comparado com experimental.

Estudos futuros, com a melhoria deste modelo (contato, atrito, parafuso, etc.) permitirão uma melhor modelagem desta região para que melhor represente o modelo físico de ruína.

\section{7 - Comparação entre resultados teóricos e experimentais}

A figura 4.33 apresenta os nós e barras que foram medido os deslocamentos e deformações, experimentalmente e numericamente, cujos valores se encontram nos gráficos das figuras 4.34 a 4.36 . 


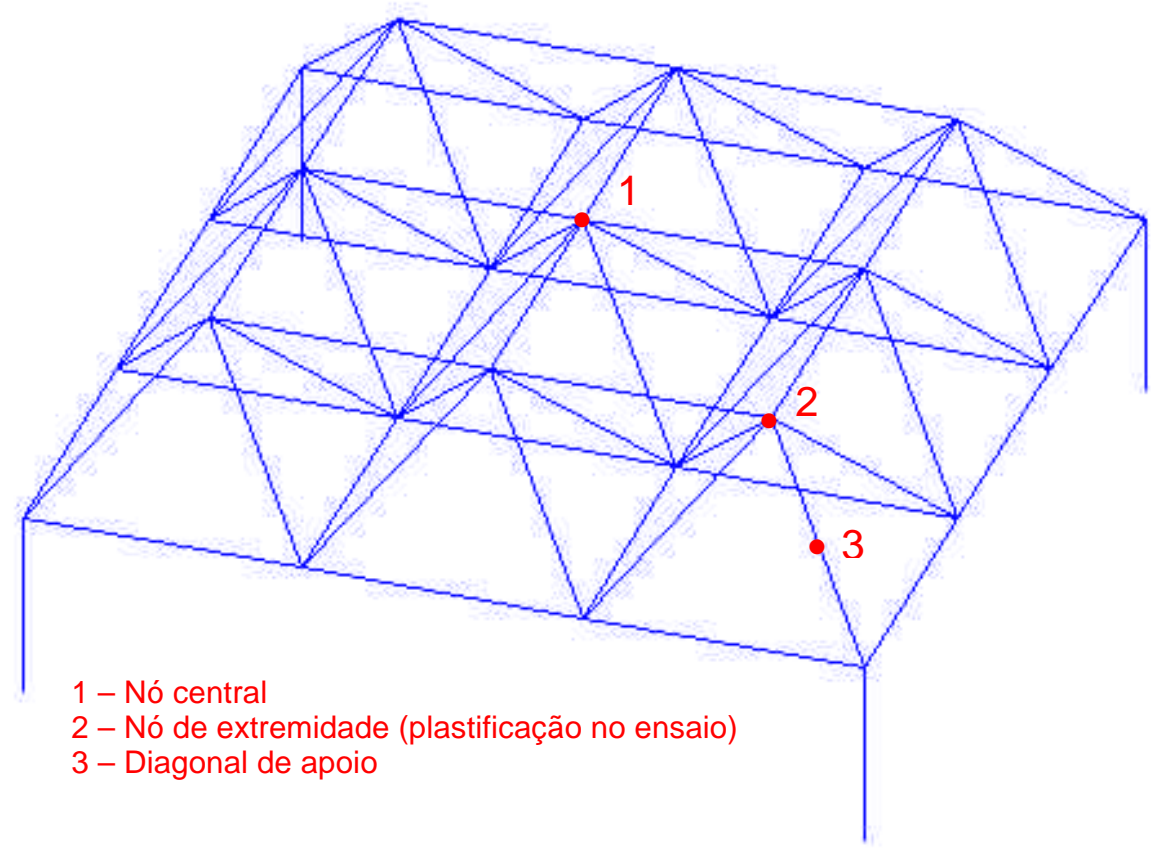

Figura 4.33 - Posição dos nós e barras analisados

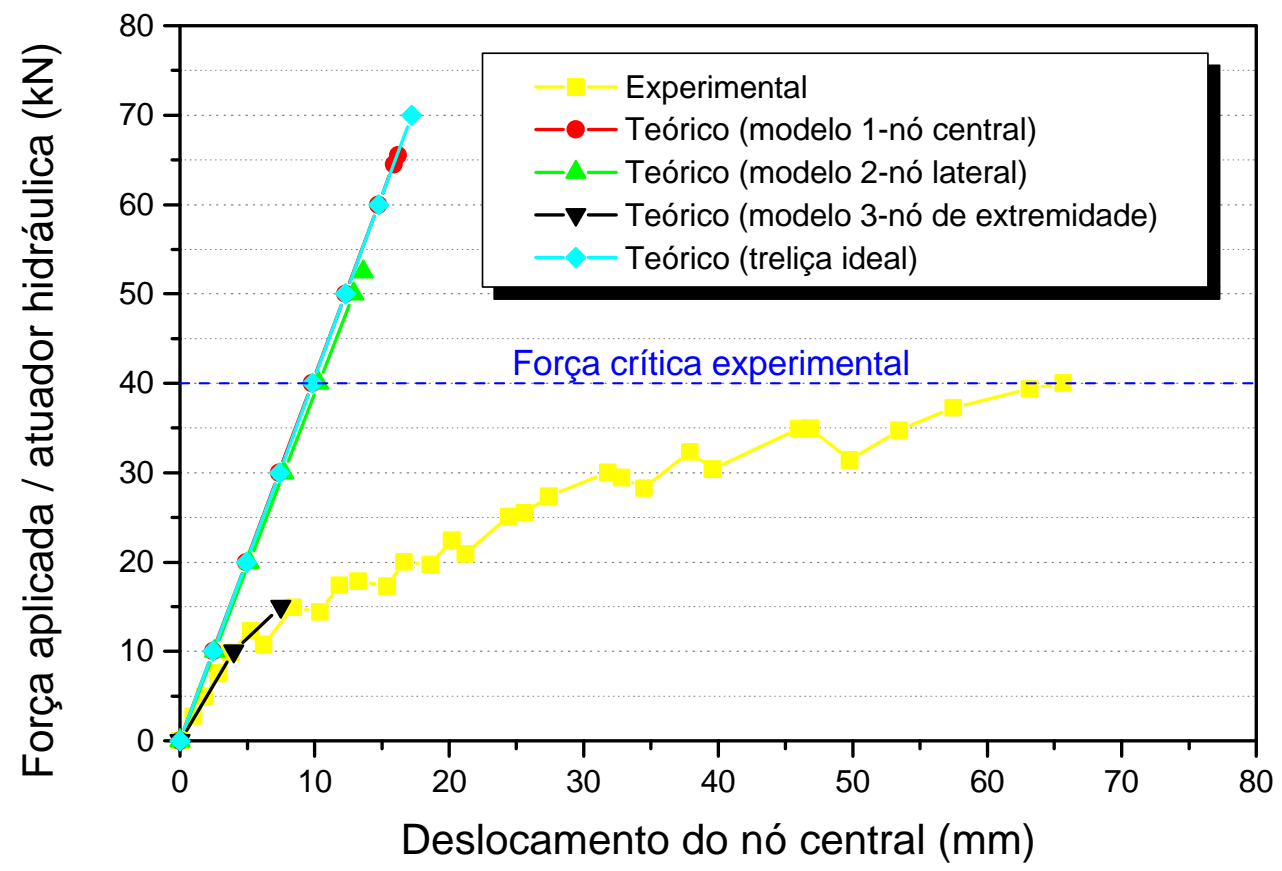

Figura 4.34 - Deslocamento teórico e experimental - nó central 


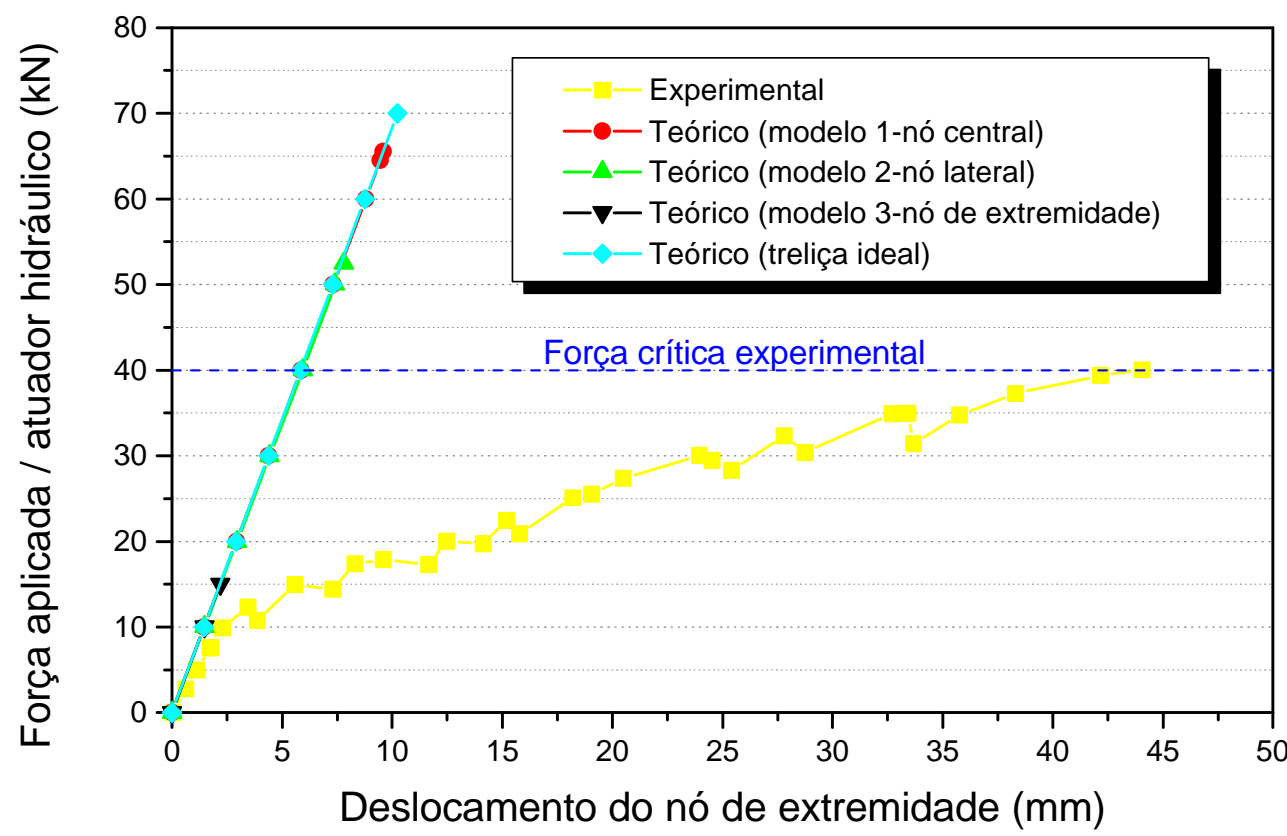

Figura 4.35 - Deslocamento teórico e experimental - nó extremidade

Observando os gráficos das figuras 4.34 e 4.35 percebe-se um comportamento fortemente não linear entre força aplicada e deslocamento para os valores experimentais e um comportamento linear para os resultados das análises numéricas.

Conclui-se, pela análise dos resultados experimentais, que as hipóteses assumidas em projetos, ou seja, treliça ideal com comportamento elástico linear não representam o comportamento da estrutura que utiliza o sistema de ligação denominada nó típico.

Este fato justifica-se pelo deslizamento dos elementos na região nodal e a rotação dos nós devido, principalmente, a presença de um único parafuso e o imperfeito contato pela impossibilidade de que todo o torque do parafuso resulte em contato efetivo das partes que compõem as extremidades das barras. 


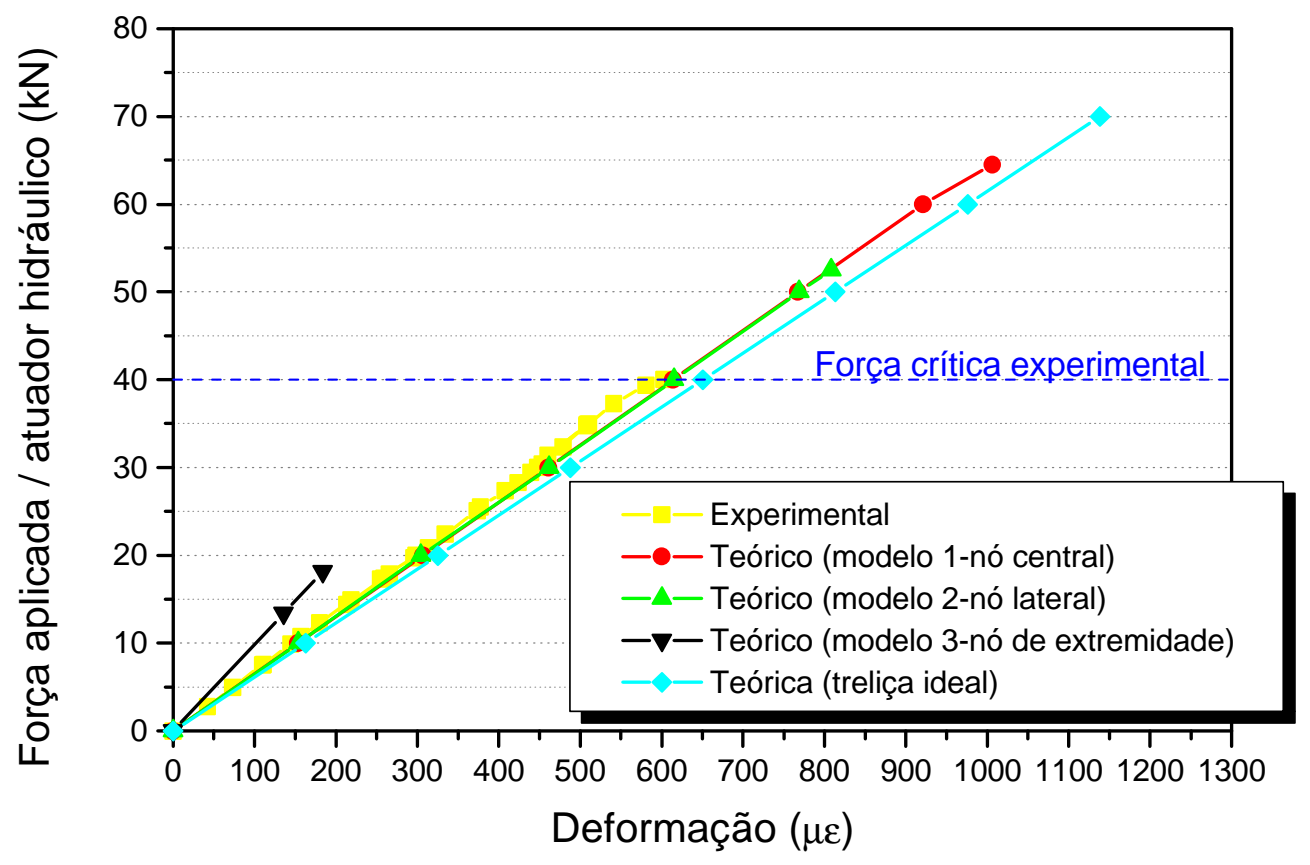

Figura 4.36 - Deformações de compressão média na seção transversal central da diagonal de apoio.

No gráfico da figura 4.36 pode-se observar que os resultados experimentais para deformações na diagonal de apoio são praticamente lineares e apresentam boa correlação com os resultados teóricos, tanto do modelo de treliça ideal como para os modelos 1 e 2, que incluem o nó com elemento de casca.

Esta concordância deve-se ao fato que, para estes modelos, a diagonal de apoio analisada possui características iguais à de uma treliça ideal, uma vez que, a inserção do nó típico com elemento de casca, não influencia o comportamento deste elemento.

Para o modelo 3 (nó extremidade) os valores das deformações indicam, apesar dos poucos resultados, um comportamento não coincidentes com os outros modelos (fig. 4.36).

Isto ocorre uma vez que, neste modelo, o nó com elemento de casca pertence a extremidade da diagonal de apoio governando o comportamento desta região devido a sua baixa rigidez, e influenciando no comportamento 
desse elemento fazendo com que a mesmo não apresente um comportamento semelhante aos dos modelos anteriores.

Em vista do exposto, conclui-se que a rigidez do nó têm influência fundamental na distribuição dos esforços nos elementos e que os modelos teóricos convencionais não são capazes de reproduzir o modo de colapso observado, caracterizado pela rotação excessiva dos nós e plastificação na região estampada dos tubos.

Uma melhoria no modelo do nó típico com elemento de casca, prevista para trabalhos futuros, permitirá um melhor entendimento desse sistema de ligação que, pelos estudos já realizados neste Departamento, apresenta desempenho limitado. 


\section{Considerações sobre projeto de cúpulas

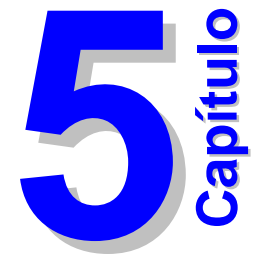

Neste capítulo apresenta-se algumas considerações necessárias para análise e dimensionamento dos elementos de uma cúpula pelos métodos convencionais, normalmente utilizados nos escritórios de cálculo.

Salienta-se que para as cúpulas, por serem estruturas especiais, não há possibilidade de se recomendar procedimentos gerais que sirva como padrão para todas as cúpulas em função dos grandes vãos normalmente utilizados e das particularidades decorrentes das condições de apoio, projeto arquitetônico, limitações de altura, etc..

O projeto da cúpula apresentado é composto por elementos tubulares de seção transversal circular, não sendo incluídos os efeitos decorrentes do amassamento das extremidades das barras sendo considerado, portanto, a inércia constante ao longo do tubo.

O nó típico, discretizado com elemento de casca, não foi utilizado nesta análise, uma vez que apenas um nó de cada vez teria que ser utilizado devido as limitações da versão do programa ANSYS existente no Departamento de Estruturas e, consequentemente, os esforços para dimensionamento não sofreriam influências significativas. Portanto, os problemas existentes neste tipo de ligação não serão incluídos nas análises 
apresentadas a seguir, enfatizando-se apenas os problemas relacionados com os elementos, porém, recomenda-se que essas considerações devam ser avaliadas em futuros trabalhos de pesquisa.

Com relação as ações a serem considerados no projeto, os carregamentos concentrados e carregamentos assimétricos provocado pelo vento, têm influências consideráveis sobre a estabilidade da estrutura, sendo indispensáveis na análise.

Outra etapa na construção de uma cúpula que merece atenção especial é a montagem. Deve-se escolher um método de montagem considerando as particularidades existentes em cada estrutura e, só assim, elaborar um plano de montagem, o qual deve ser projetado e verificado estruturalmente.

Para apresentação dos procedimentos de projeto, seguem-se as recomendações das seguintes normas brasileiras:

NBR 8800 - Projeto e execução de estruturas de aço de edifícios

NBR 6123 - Forças devidas ao vento em edificações

NBR 6120 - Cargas para o cálculo de estruturas de edificações

\section{1- Descrição da estrutura analisada}

A cúpula analisada possui uma área em planta de $5.127 \mathrm{~m}^{2}(80,8 \mathrm{~m}$ de diâmetro), com 24 colunas de seção transversal 1,0×0,5 m para apoios da estrutura e com fechamento lateral de paredes. A cúpula é constituída por duas camadas espaçadas entre si de 2,0 m, que se unem através de elementos diagonais.

As malhas, inferior e superior, bem como as diagonais são compostas por tubos de seção transversal circular com extremidades estampadas em aço de qualidade estrutural com $f_{y}=250 \mathrm{MPa}$ e conformados a frio com solda contínua de costura. 
Para cobertura foram utilizadas telhas em aço com $2 \mathrm{~mm}$ de espessura com pontos de fixação coincidentes com os nós da malha superior da cúpula.

As figuras $5.1 \mathrm{a}$ a $5.1 \mathrm{f}$ apresentam os aspectos gerais da estrutura modelada com auxílio do programa ANSYS.

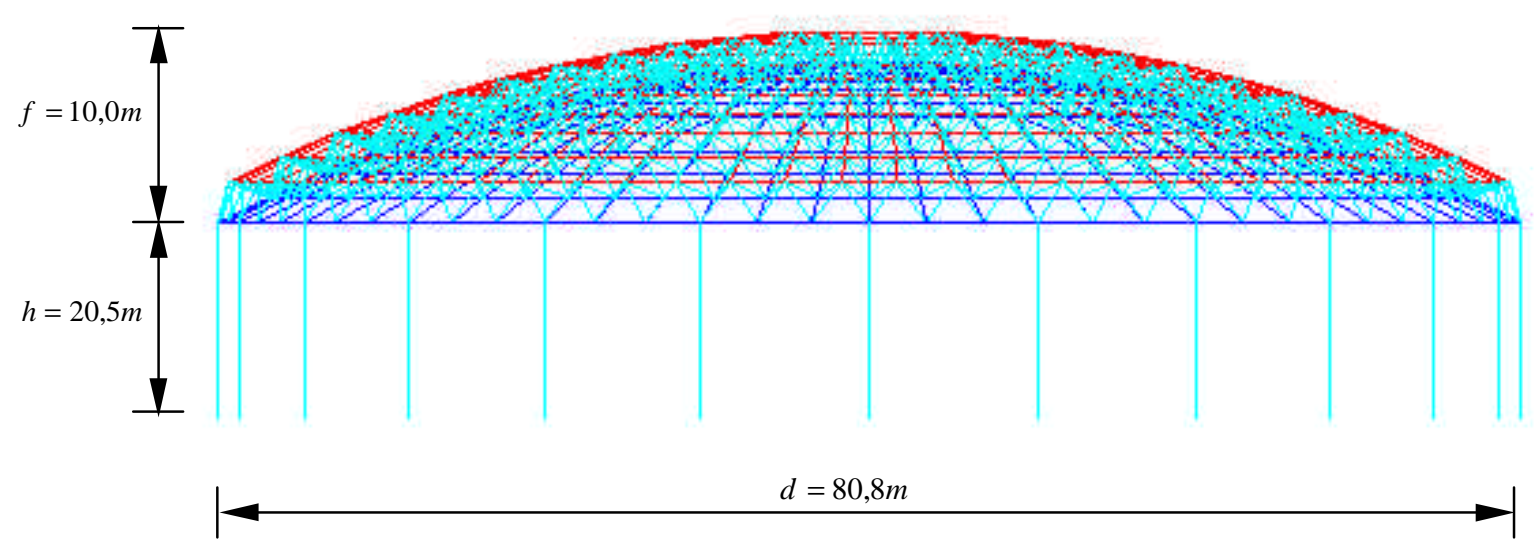

a) Vista lateral

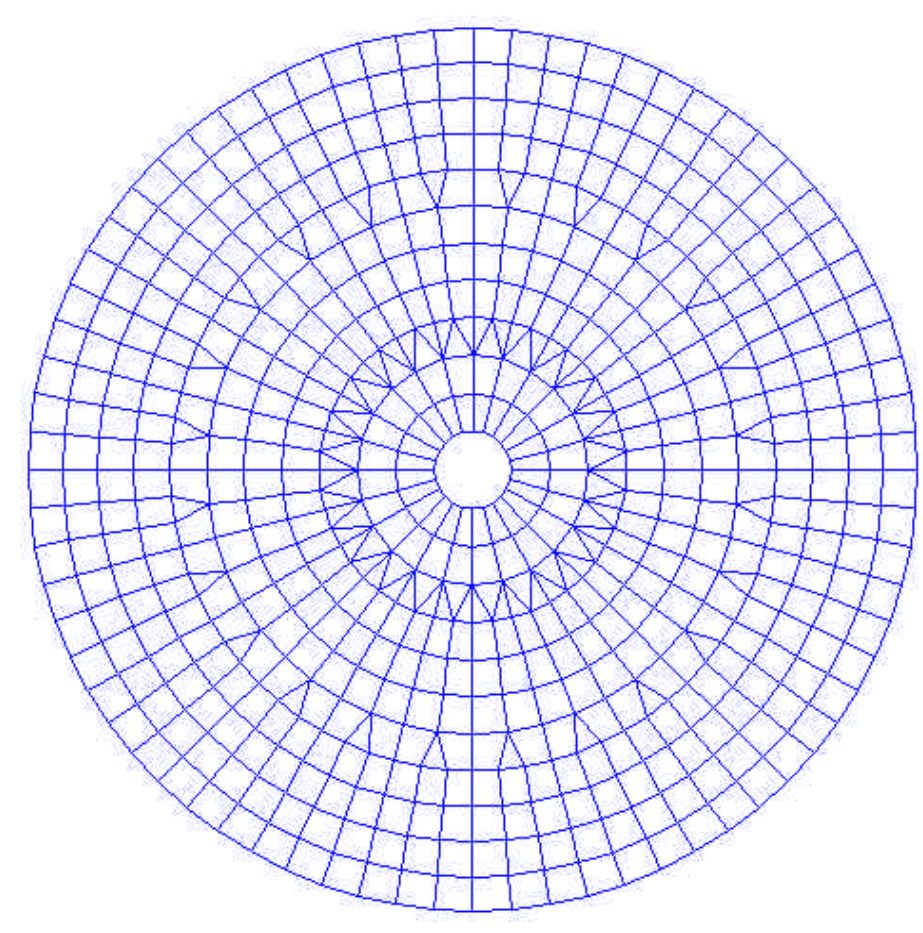

b) Elementos da malha inferior 


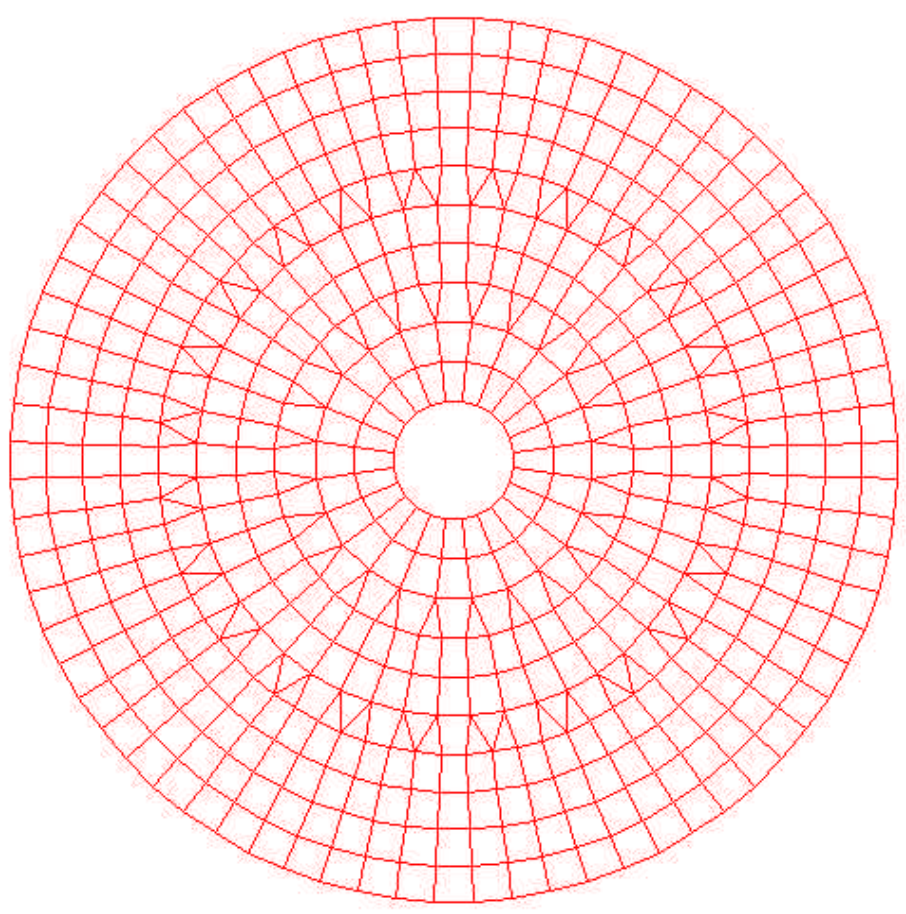

c) Elementos da malha superior

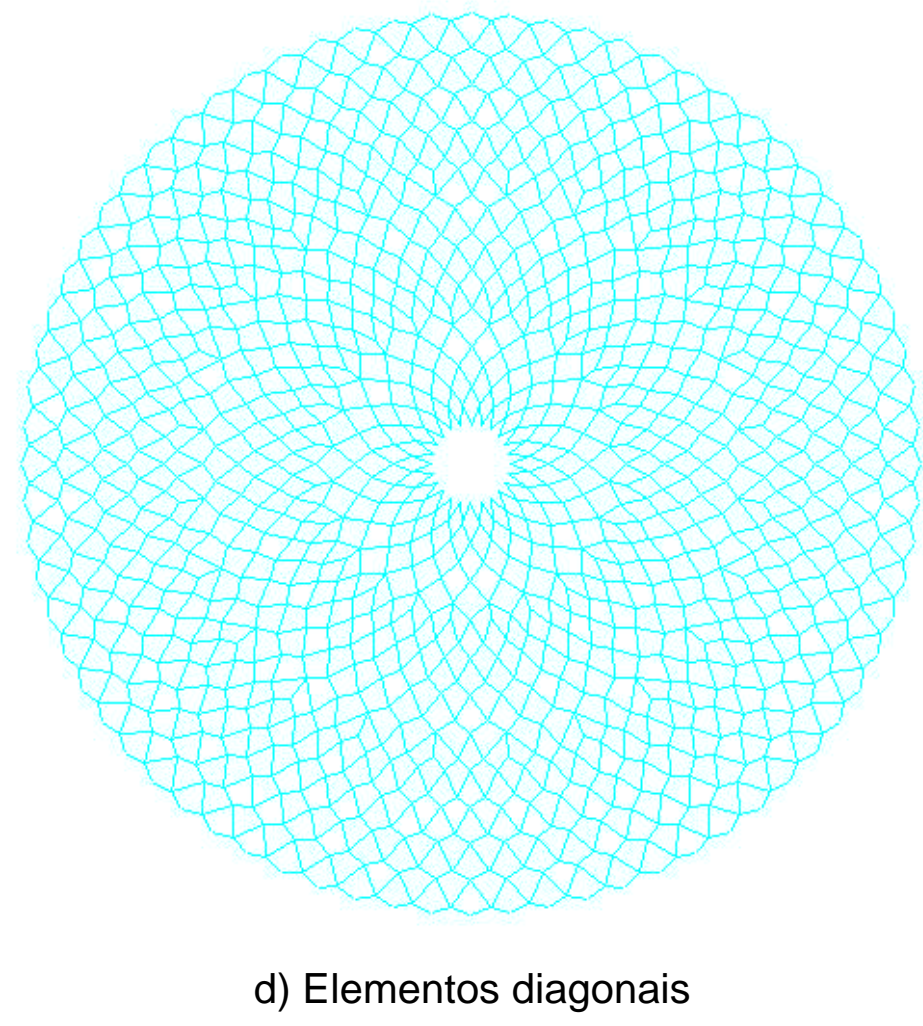




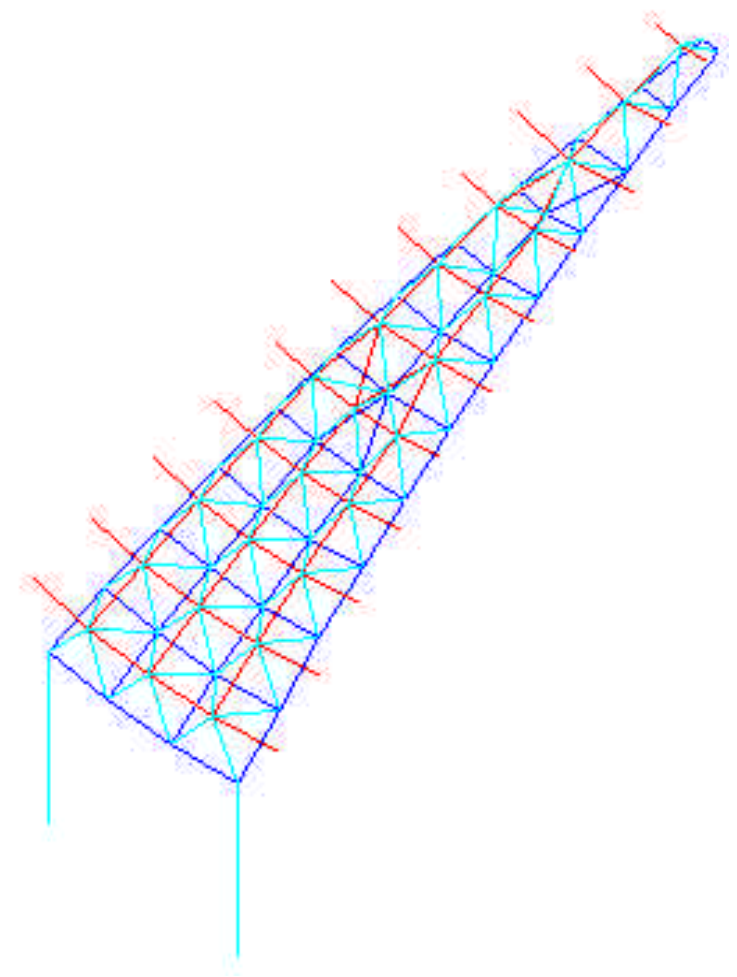

e) Setor padrão

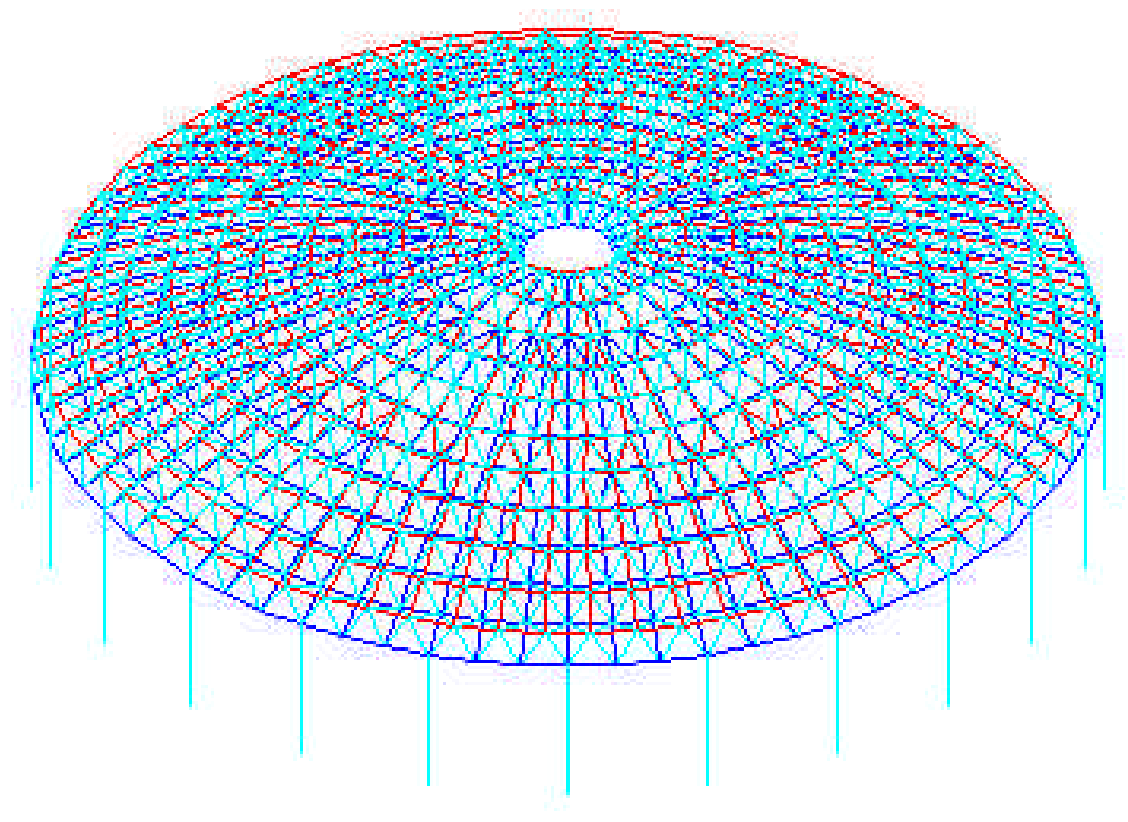

f) Vista geral da estrutura

Figura 5.1 - Estrutura analisada 


\section{2- Ações consideradas no projeto}

\subsection{1- Ações permanentes}

Em coberturas espaciais usuais, o peso próprio para estruturas em aço é da ordem de 0,1 a $0,3 \mathrm{kN} / \mathrm{m}^{2}$. O sistema de vedação quando construído com telhas de aço ou alumínio pesa em torno de 0,05 a 0,12 $\mathrm{kN} / \mathrm{m}^{2}$ e com telhas de fibrocimento de 0,18 a $0,3 \mathrm{kN} / \mathrm{m}^{2}$.

Neste exemplo, utilizou-se telhas de aço com 2,0 mm de espessura com peso estimado em $0,07 \mathrm{kN} / \mathrm{m}^{2}$ e o peso próprio da estrutura gerado automaticamente pelo programa com o fornecimento do peso específico do material.

\subsection{2- Ações Variáveis}

Como ações variáveis podem ser consideradas a sobrecarga no telhado e em plataformas de serviços, os efeitos do vento, os acúmulos de águas pluviais e variações de temperatura.

Neste exemplo, foram consideradas como ações variáveis uma sobrecarga de $0,25 \mathrm{kN} / \mathrm{m}^{2}$ e o efeito do vento, que será descrito mais detalhadamente no item seguinte.

Convém ressaltar que as ações geradas pelo efeito do vento são as de maior necessidade de atenção em estruturas em forma de cúpulas.

\subsubsection{1- Ações devido ao vento}

O principal aspecto com relação a velocidade do vento é que regiões diferentes da terra estão sujeitas a diferentes situações da velocidade do vento. 
É importante determinar a velocidade do vento para uma determinada região, considerando também que os resultados desta medição sofrem variabilidade ao longo do tempo.

Para uma dada edificação tem-se que sua vida útil é normalizada em 50 anos sendo necessário considerar este aspecto na análise do vento. Portanto é necessário considerar qual será a velocidade máxima que ocorrerá neste período.

a) Velocidade básica

A velocidade básica do vento esta relacionada com as condições em que as medidas de velocidade do vento natural são realizadas.

As condições de avaliação para a velocidade do vento seguem as seguintes recomendações:

- localização dos aparelhos (anemômetros, anemôgrafos) de medidas em terrenos planos sem obstrução;

- posicionamento a $10 \mathrm{~m}$ de altura;

- inexistência de obstrução que possam interferir diretamente na velocidade do vento.

A NBR-6123-1988 estabelece para a velocidade básica um gráfico de isopletas, figura 10, baseado nas seguintes condições:

- velocidade básica para uma rajada de três segundos;

- período de retorno de 50 anos;

- probabilidade de $63 \%$ de ser excedida pelo menos uma vez no período de retorno de 50 anos;

- altura de $10 \mathrm{~m}$;

- terreno plano, em campo aberto e sem obstruções. 
Os valores máximos para velocidade apresentado na figura 5.2, foram obtidas através de informações de várias estações meteorológicas com o devido tratamento estatístico.

Sabe-se que nem sempre as edificações seguirão estes padrões e portanto correções deverão ser feitas para cada caso particular de cada edificação.

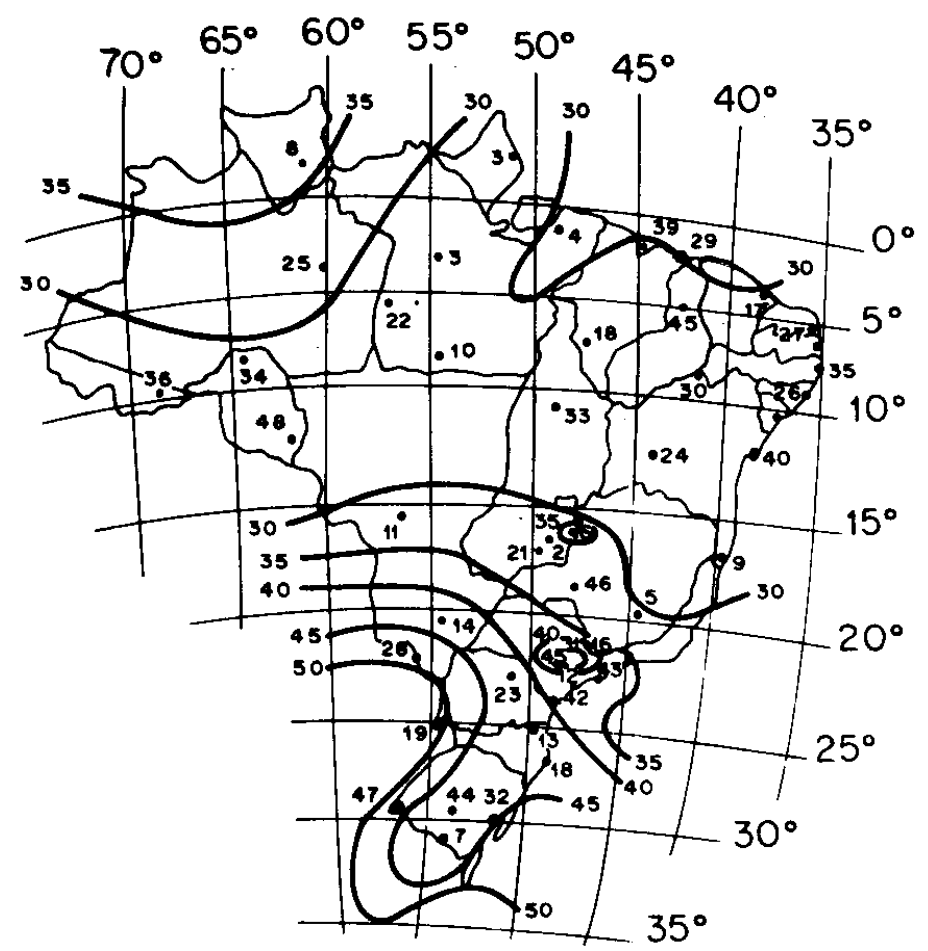

Figura $5.2^{1}$ - Gráficos de isopletas da velocidade básica do vento $(\mathrm{m} / \mathrm{s})$

b) Velocidade característica

Segundo Gonçalves et al (1996) a velocidade básica é praticamente um padrão de referência a partir do qual deverão ser feitas as correções para obtermos a velocidade característica que atuará na estrutura.

\footnotetext{
${ }^{1}$ Gonçalves (1996)
} 
Para obtermos esta velocidade característica, vários fatores relacionados com a edificação devem ser levados em consideração, entre estes podemos citar:

- topografia local;

- rugosidade do terreno;

- altura da edificação;

- dimensões da edificação;

- tipo de ocupação e risco de vida.

Portanto a NBR-6123/1988 defini a velocidade característica da seguinte maneira:

$$
V_{K}=V_{0} * S_{1} * S_{2} * S_{3}
$$

onde:

$V_{K}$ - velocidade característica do vento;

$V_{0} \quad$ - velocidade básica do vento;

$S_{1}$ - fator topográfico que considera os efeitos das variações do relevo onde a edificação será construída;

$S_{2}$ - fator que considera as particularidades de uma dada edificação com relação às dimensões, bem como a rugosidade média do terreno no qual o edificação será construída;

$S_{3}$ - fator que está relacionado com a segurança da edificação considerando, para isto, conceitos probabilísticos e o tipo de ocupação.

c) Ação do vento em cúpulas

Segundo a NBR 6123 / 1988 - Forças devidas ao vento em edificações, as pressões externas em superfícies curvas dependem da variação do fluxo, os quais variam com a velocidade do vento, características de sua turbulência, dimensões e relação entre as dimensões 
da edificação, curvatura da superfície externa da cobertura e sua rugosidade, etc.

Segundo esta norma, somente valores aproximados de coeficiente de pressão externa $\left(C_{p e}\right)$ podem ser dados para as cúpulas, devido à variação da distribuição das pressões com as características do vento, da relação entre as dimensões da edificação e da superfície externa da cúpula. Estudos especiais devem ser feitos no caso de cúpulas de grandes dimensões.

Quanto ao coeficiente de pressão interna $\left(C_{p i}\right)$ deve ser consideradas as possibilidades de aberturas e permeabilidade da estrutura de fechamento.

\section{3- Cálculo da ação do vento para cúpula estudada}

a) Dados gerais da edificação

- Localização da edificação: São Carlos - SP

- Finalidade da edificação: Ginásio de esportes

- Velocidade básica do vento $\Rightarrow V_{0}=45 \mathrm{~m} / \mathrm{s}$

- Fator topográfico: terreno plano $\Rightarrow S_{1}=1,0$

- Rugosidade do terreno e dimensões da edificação $\Rightarrow S_{2}=0,95$

- Terreno plano com edificações baixas e esparsas: Categoria III

- Maior dimensão da edificação excede 50 m: Classe C

- Fator estatístico de segurança $\Rightarrow S_{3}=1,0$

- Edificação com alto fator de ocupação 
b) Velocidade característica

$$
\begin{aligned}
& V_{K}=V_{0} * S_{1} * S_{2} * S_{3} \\
& V_{K}=45 * 1,0 * 0,95 * 1,0 \quad \Rightarrow V_{K}=43,0 \mathrm{~m} / \mathrm{s}
\end{aligned}
$$

c) Pressão de obstrução

$$
\begin{aligned}
& q=0,613 * V_{K}^{2} \\
& q=0,613 * 43^{2} \quad \Rightarrow q=1,14 k N / m^{2}
\end{aligned}
$$

d) Coeficiente de pressão externa $\left(C_{p e}\right)$

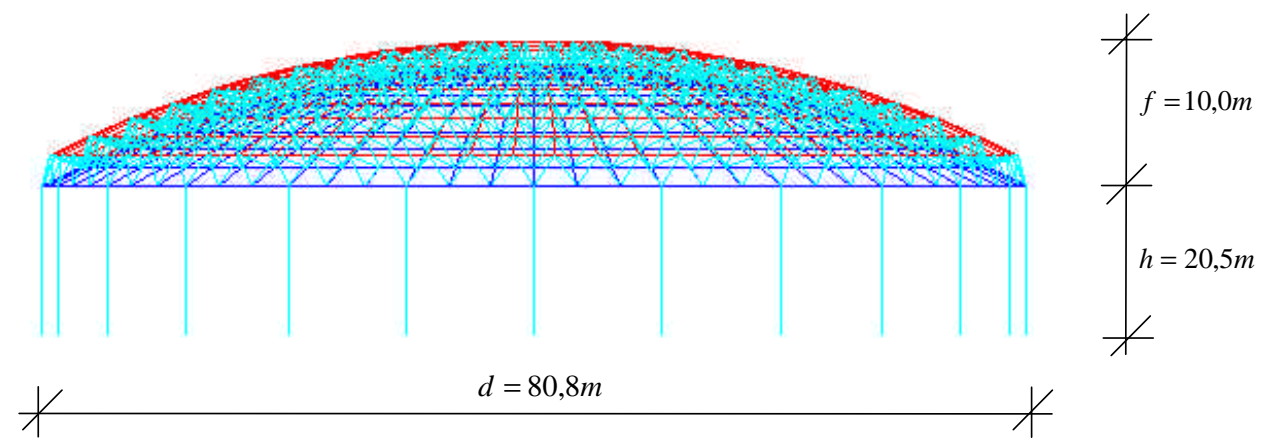

Relação entre as dimensões da estrutura:

$$
\frac{f}{d}=\frac{10,0}{80,8} \quad \Rightarrow \frac{f}{d}=\frac{1}{8,08}
$$




$$
\frac{h}{d}=\frac{20,5}{80,8} \quad \Rightarrow \frac{h}{d}=\frac{1}{3,94}
$$

Com auxílio da NBR-6123 podemos obter os seguintes coeficientes de pressão externa para a estrutura analisada:

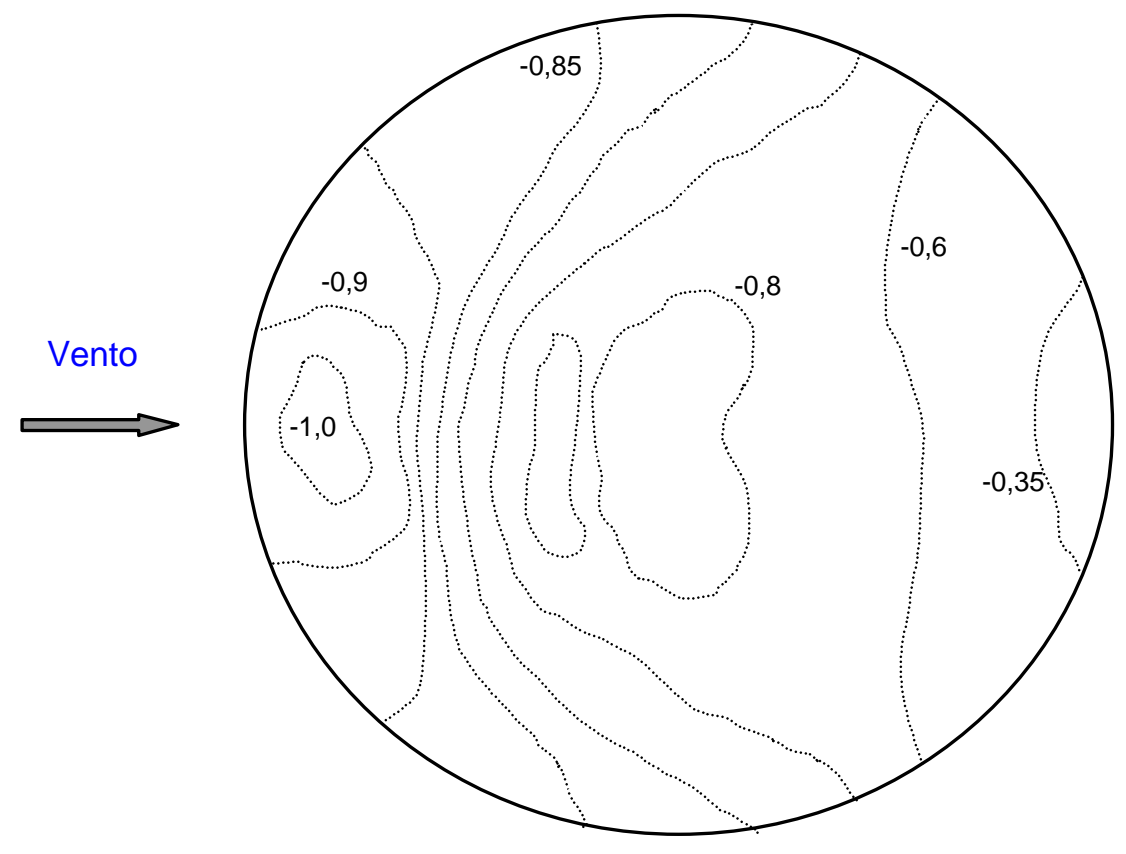

e) Coeficiente de pressão interna $\left(C_{p i}\right)$

Para considerar o coeficiente de pressão interna $\left(C_{p i}\right)$ para a cúpula analisada, torna-se aplicável o item 6.2.6 da norma NBR-6123, reproduzido a seguir:

"6.2.6 - Para edificações efetivamente estanques e com janelas fixas que tenham uma probabilidade desprezível de serem rompidas por acidentes, considerar o mais nocivo entre os valores $C_{p i}=-0,2$ ou $C_{p i}=0 . "$ 
Como para a cúpula analisada o vento agindo externamente provoca apenas sucção, foi adotado $C_{p i}=0$, uma vez que o $C_{p i}=-0,2$ diminuiria o coeficiente de pressão externa $\left(C_{p e}\right)$ obtido anteriormente.

f) Resumo dos coeficientes de pressão

Em escritórios de projetos é comum simplificar o cálculo das ações devido ao vento, adotando os coeficientes de pressão totais $\left(C_{p e}+C_{p i}\right)$ por setores. A figura 5.3 apresenta estes coeficientes e seus setores de atuação em função da direção da ação do vento.

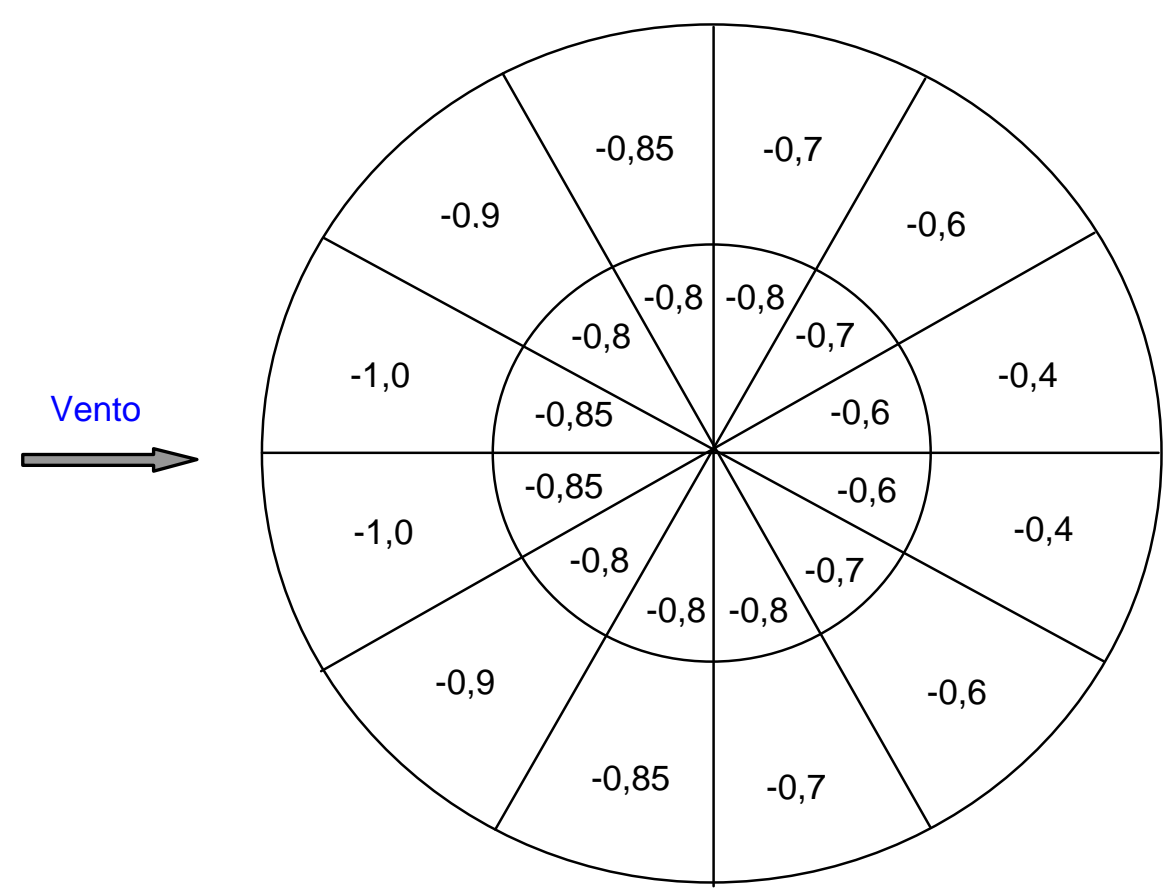

Figura 5.3 - Resumo dos coeficientes de pressão 
g) Cálculo das forças geradas pela ação do vento

Para o cálculo das forças geradas pelo vento, procede-se da seguinte maneira:

1- Calcula-se a área de influência para cada nó existente nos vários anéis horizontais do banzo superior da cúpula;

2- Com a área de influência para cada nó, pressão de obstrução e coeficiente de pressão total, calcula-se a força para cada nó da camada superior, agindo perpendicularmente a superfície da cúpula;

3- Com a força perpendicular a superfície em cada nó do banzo superior, faz-se a decomposição nas direções dos eixos $X, Y$ e Z para entrada de dados no programa ANSYS.

\section{4 - Resumo das forças aplicadas à estrutura}

A tabela 5.1 apresenta um resumo de todas as forças que agem sobre a estrutura: 
Tabela 5.1 - Resumo das ações aplicadas na estrutura

\begin{tabular}{|c|c|c|c|c|c|c|c|c|c|c|c|}
\hline \multirow[t]{2}{*}{ Anel } & \multirow{2}{*}{$\begin{array}{l}\text { Número } \\
\text { de nós }\end{array}$} & \multirow{2}{*}{$\begin{array}{l}\text { Área de influência } \\
\text { para cada nó }\left(\mathrm{m}^{2}\right)\end{array}$} & \multirow{2}{*}{$\begin{array}{l}\text { Peso próprio } \\
\text { (KN) }\end{array}$} & \multirow{2}{*}{$\begin{array}{l}\text { Peso da telha } \\
\text { (KN) }\end{array}$} & \multirow{2}{*}{$\begin{array}{l}\text { Sobrecarga } \\
\text { (KN) }\end{array}$} & \multicolumn{6}{|c|}{ Força de sucção perpendicular a superfície da cúpula (KN) } \\
\hline & & & & & & setor 1 & setor 2 & setor 3 & setor 4 & setor 5 & setor 6 \\
\hline $1^{\circ}$ anel & 72 & 6,84 & Geração automática & 0,48 & 1,41 & $-7,80$ & $-7,02$ & $-6,63$ & $-5,46$ & $-4,68$ & $-3,12$ \\
\hline $2^{\circ}$ anel & 72 & 12,97 & Geração automática & 0,91 & 3,24 & $-14,79$ & $-13,31$ & $-12,57$ & $-10,35$ & $-8,87$ & $-5,91$ \\
\hline $3^{\circ}$ anel & 72 & 11,94 & Geração automática & 0,84 & 2,98 & $-13,61$ & $-12,25$ & $-11,57$ & $-9,53$ & $-8,17$ & $-5,44$ \\
\hline $4^{\circ}$ anel & 72 & 11,94 & Geração automática & 0,84 & 2,98 & $-13,61$ & $-12,25$ & $-11,57$ & $-9,53$ & $-8,17$ & $-5,44$ \\
\hline 5o anel & 72 & 8,88 & Geração automática & 0,62 & 2,22 & $-8,6$ & $-8,09$ & $-8,09$ & $-8,09$ & $-7,08$ & $-6,07$ \\
\hline 60 anel & 48 & 14,82 & Geração automática & 1,04 & 3,71 & $-14,36$ & $-13,52$ & $-13,52$ & $-13,52$ & $-11,83$ & $-10,14$ \\
\hline $7^{\circ}$ anel & 48 & 13,25 & Geração automática & 0,93 & 3,31 & $-12,83$ & $-12,08$ & $-12,08$ & $-12,08$ & $-10,57$ & $-9,06$ \\
\hline 8o anel & 48 & 11,63 & Geração automática & 0,81 & 2,91 & $-11,27$ & $-10,61$ & $-10,61$ & $-10,61$ & $-9,28$ & $-7,96$ \\
\hline 9 anel & 24 & 20,05 & Geração automática & 1,40 & 5,01 & $-19,42$ & $-18,28$ & $-18,28$ & $-18,28$ & $-16,00$ & $-13,71$ \\
\hline $10^{\circ}$ anel & 24 & 7,54 & Geração automática & 0,53 & 1,88 & $-7,31$ & $-6,88$ & $-6,88$ & $-6,88$ & $-6,02$ & $-5,16$ \\
\hline $11^{\circ}$ anel & 24 & 6,77 & Geração automática & 0,37 & 1,33 & $-6,56$ & $-6,18$ & $-6,18$ & $-6,18$ & $-5,41$ & $-4,63$ \\
\hline
\end{tabular}

Obs.1 - Os sinais negativos indicam forças de sucção na parte externa da cobertura;

Obs.2 - As forças de sucção foram decompostas nas direções X, Y e Z para facilitar a entrada de dados no ANSYS;

Obs.3 - Geração automática entende-se o fornecimento apenas do peso específico do material. 


\section{5 - Pré-dimensionamento}

Para uma primeira análise da estrutura, é comum realizar um prédimensionamento para avaliar as dimensões da seção transversal dos tubos que a compõe.

Este pré-dimensionamento baseia-se em fixar um determinado valor para o índice de esbeltez $(\lambda)$ para os elementos sem, no entanto, se preocupar com os esforços que agem sobre eles. As seções encontradas neste pré-dimensionamento podem ser vistas na figura 5.4a a 5.4c.

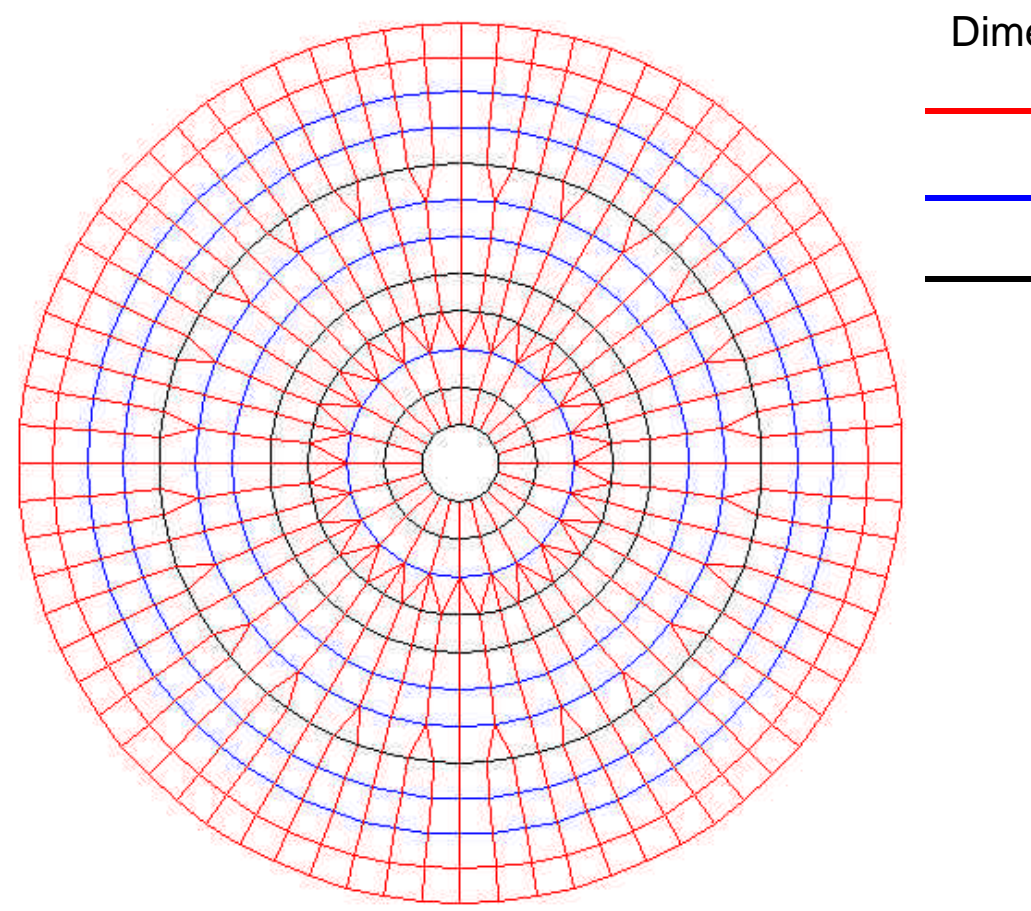

$\lambda \cong 100$

a) Elementos do banzo inferior 


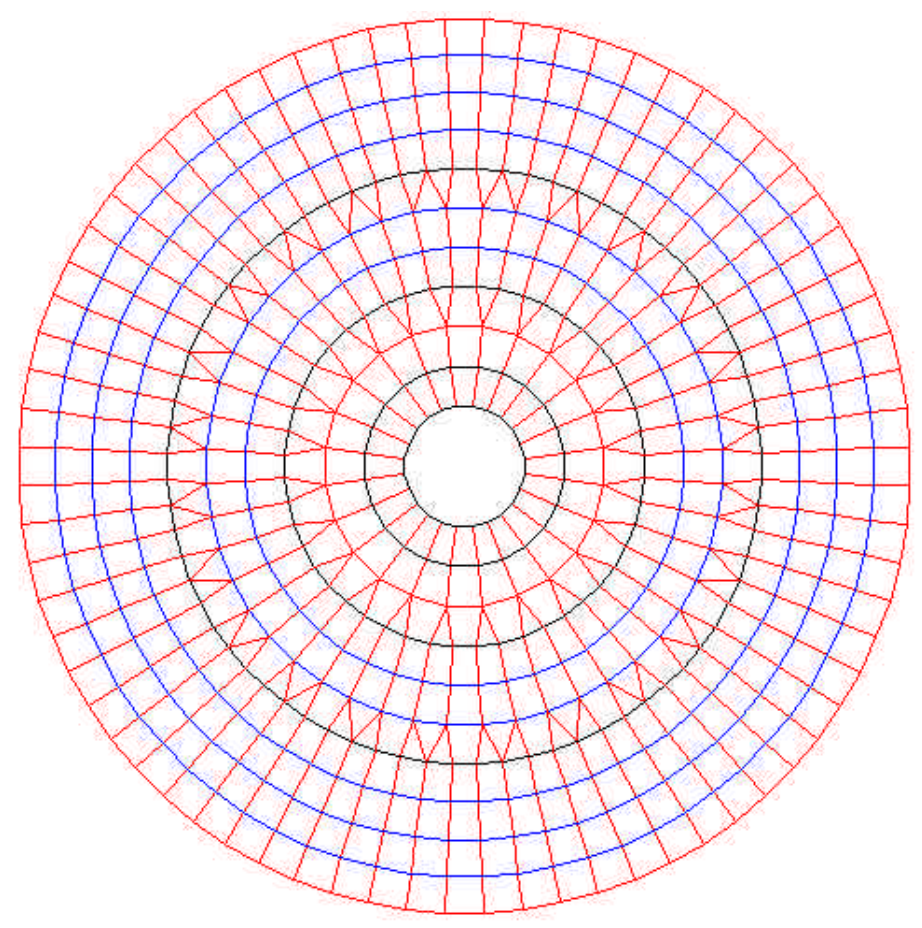

Dimensões dos tubos

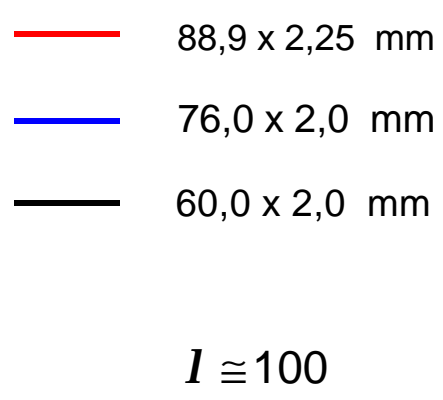

b) Elementos do banzo superior

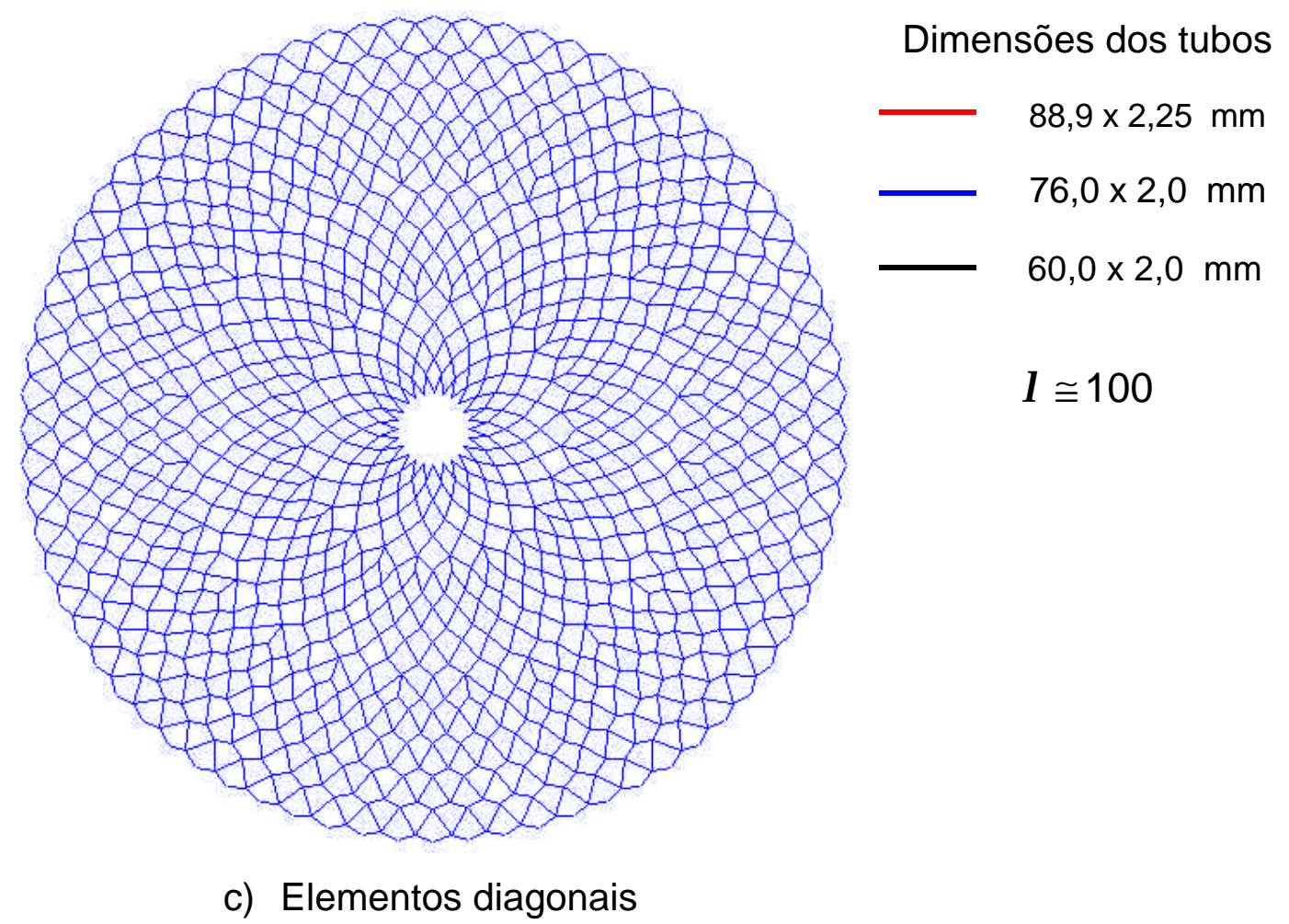

Figura 5.4 - Pré-dimensionamento dos elementos 


\section{6 - Obtenção dos esforços}

Para obtenção dos esforços nas barras que constituem a estrutura utilizou-se o programa de análise ANSYS, assumindo-se um comportamento estrutural com linearidade física e geométrica.

O elemento adotado para todas as barras da estrutura é o BEAM4. Este elemento possui seis graus de liberdade em cada nó sendo três translações nas direções $X, Y$ e $Z$ e três rotações em relação aos eixos $X, Y$ e Z. A geometria, localização dos nós e o sistema de coordenadas para este elemento são apresentados na figura 5.5.

Este elemento é definido por dois nós, área da seção transversal, dois momentos de inércia $\left(I_{Z Z} e I_{Y Y}\right)$, duas espessuras (TKYeTKZ), um ângulo de orientação $(\theta)$ sobre o eixo $x$ do elemento, o momento de inércia a torção $\left(I_{X X}\right)$ e a propriedade do material, sendo que a orientação do eixo $x$ do elemento é do nó $I$ para o nó $J$.

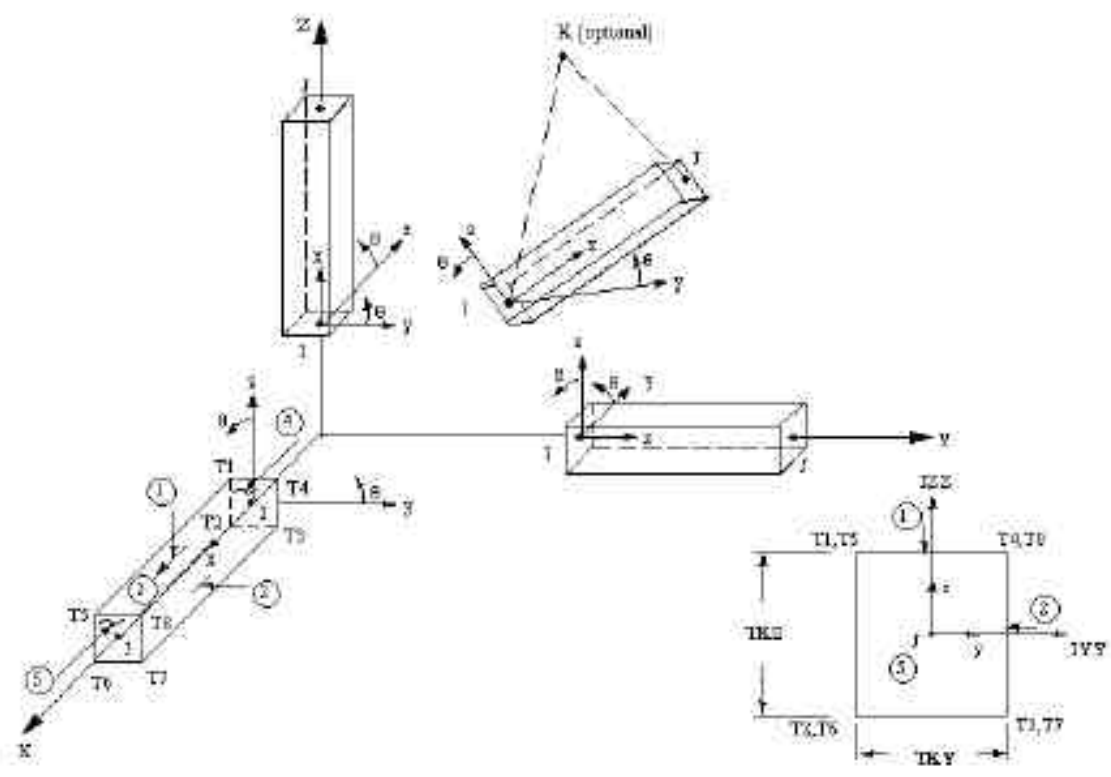

Figura $5.5^{1}$ - Elemento BEAM4

\footnotetext{
${ }^{1}$ Ansys Elements Reference - Release 5.4 (1997)
} 


\section{7- Apresentação dos esforços}

Os carregamentos para dimensionamento dos elementos que constituem a estrutura foram obtidos considerando as seguintes combinações das ações:

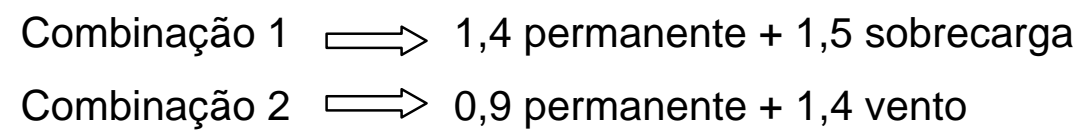

No caso de ocorrência de vento de sobrepressão dever-se-ia ainda considerar as seguintes combinações:

Combinação $3 \Longrightarrow 1,4$ perm. $+1,5$ sobrecarga $+1,4$ * 0,6 v. sobrepressão Combinação $4 \Longrightarrow 1,4$ perm. $+1,4$ v. sobrepressão $+1,5$ * 0,65 sobrecarga

As figuras 5.6a a 5.6c apresentam os esforços axiais para a combinações 1 dos elementos da malha inferior, malha superior e diagonais.

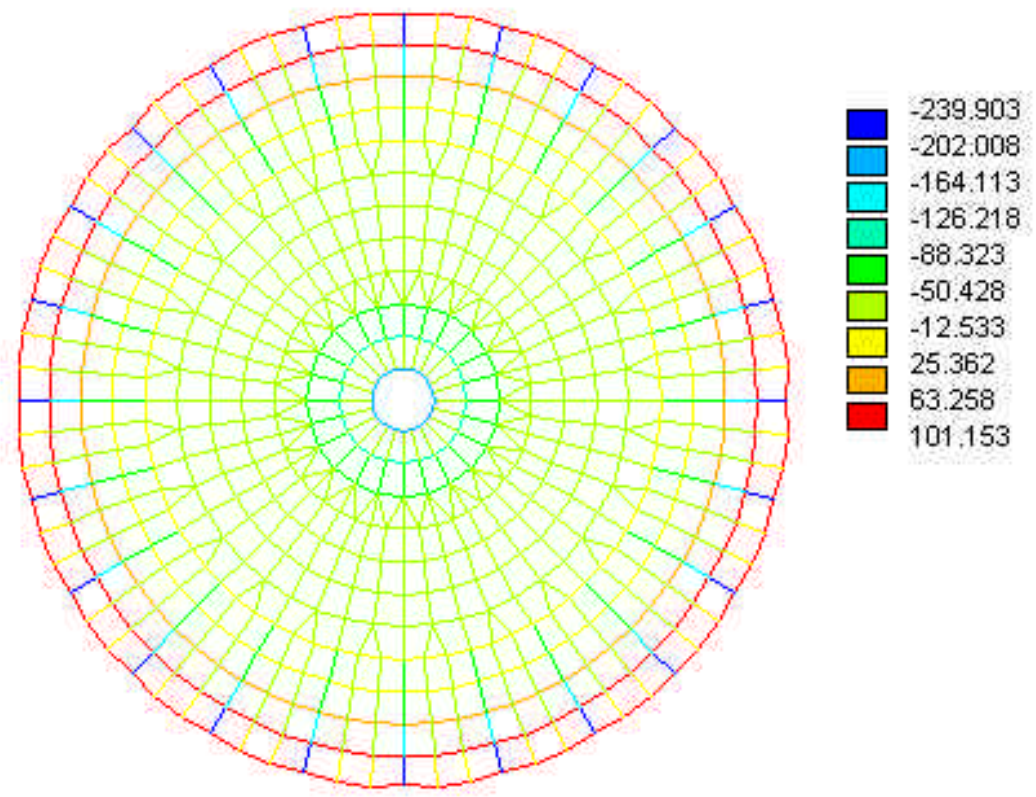

a) Esforços axiais para os elementos da malha inferior $(\mathrm{kN})$ 


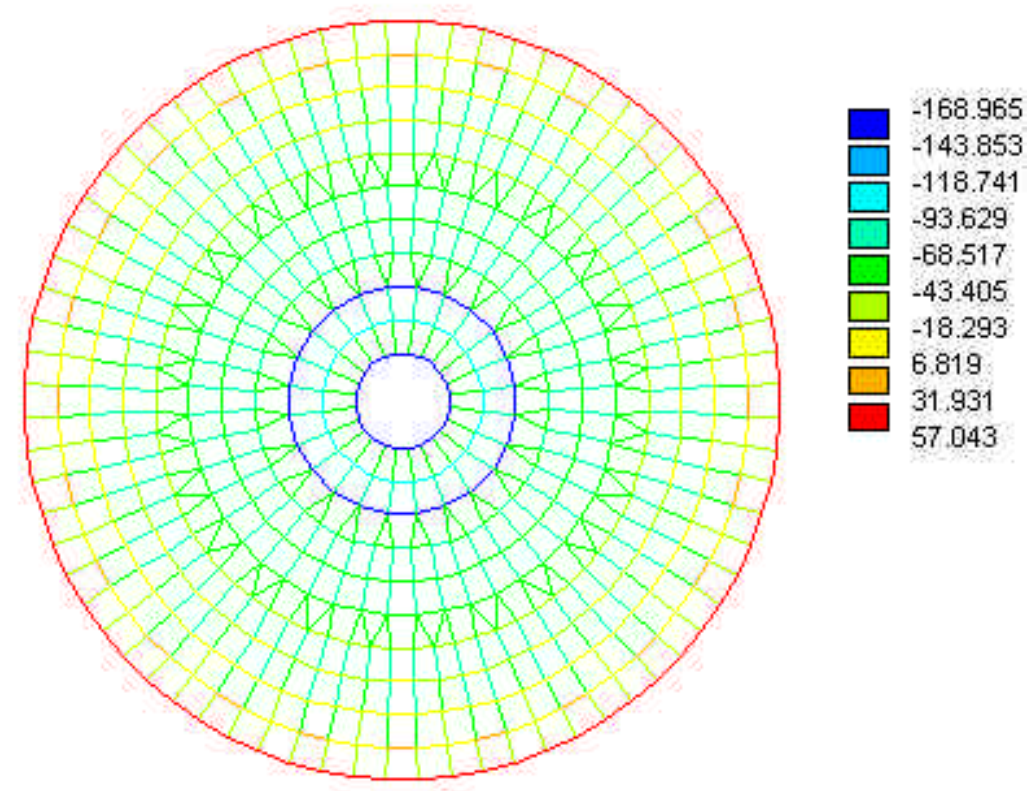

b) Esforços axiais para os elementos da malha superior $(\mathrm{kN})$

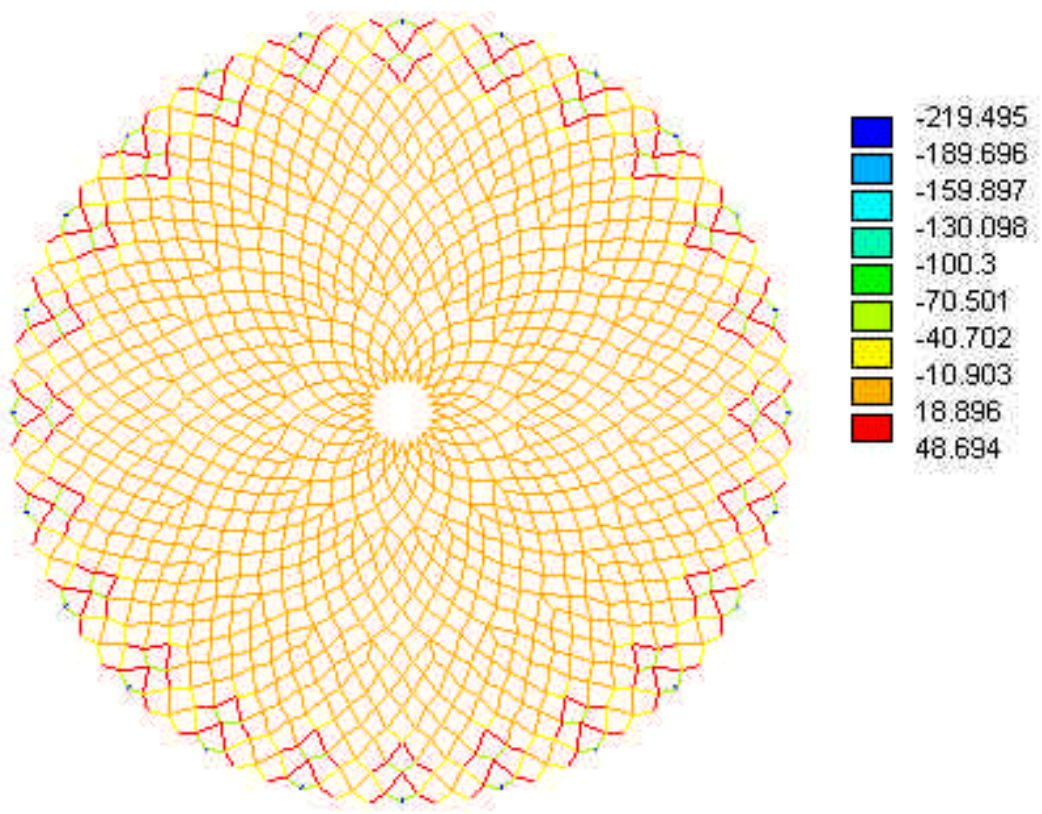

c) Esforços axiais para os elementos diagonais $(\mathrm{kN})$

Figura 5.6 - Esforços nos elementos da cúpula para combinação 1 
As figuras 5.7a a 5.7c apresentam os esforços axiais para a combinação 2 dos elementos da malha inferior, malha superior e diagonais.

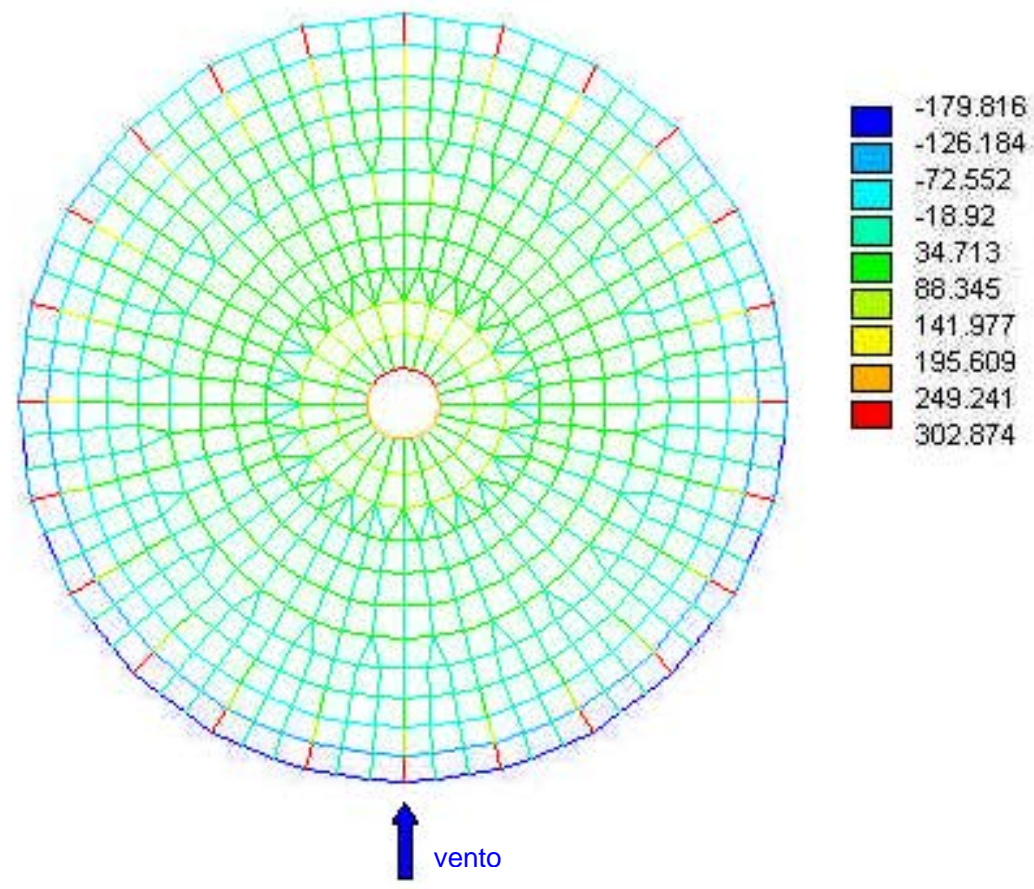

a) Esforços axiais para os elementos da malha inferior ( $\mathrm{kN})$

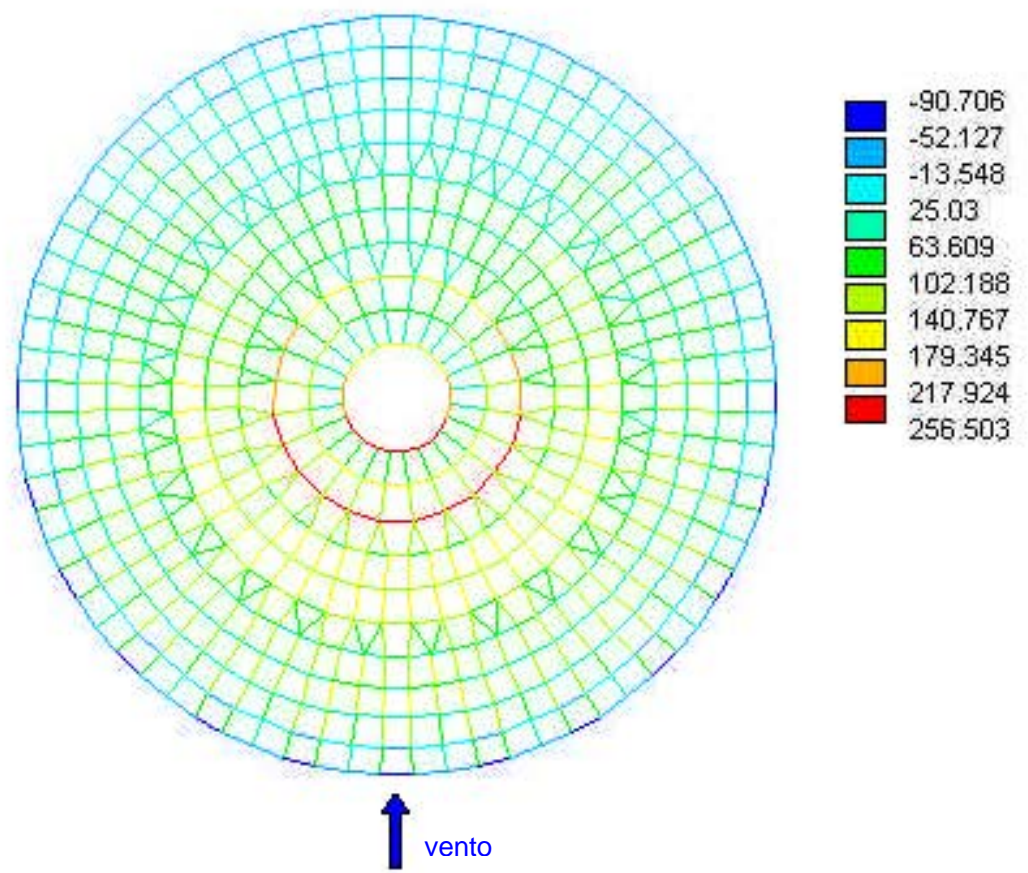

b) Esforços axiais para os elementos da malha superior $(\mathrm{kN})$ 


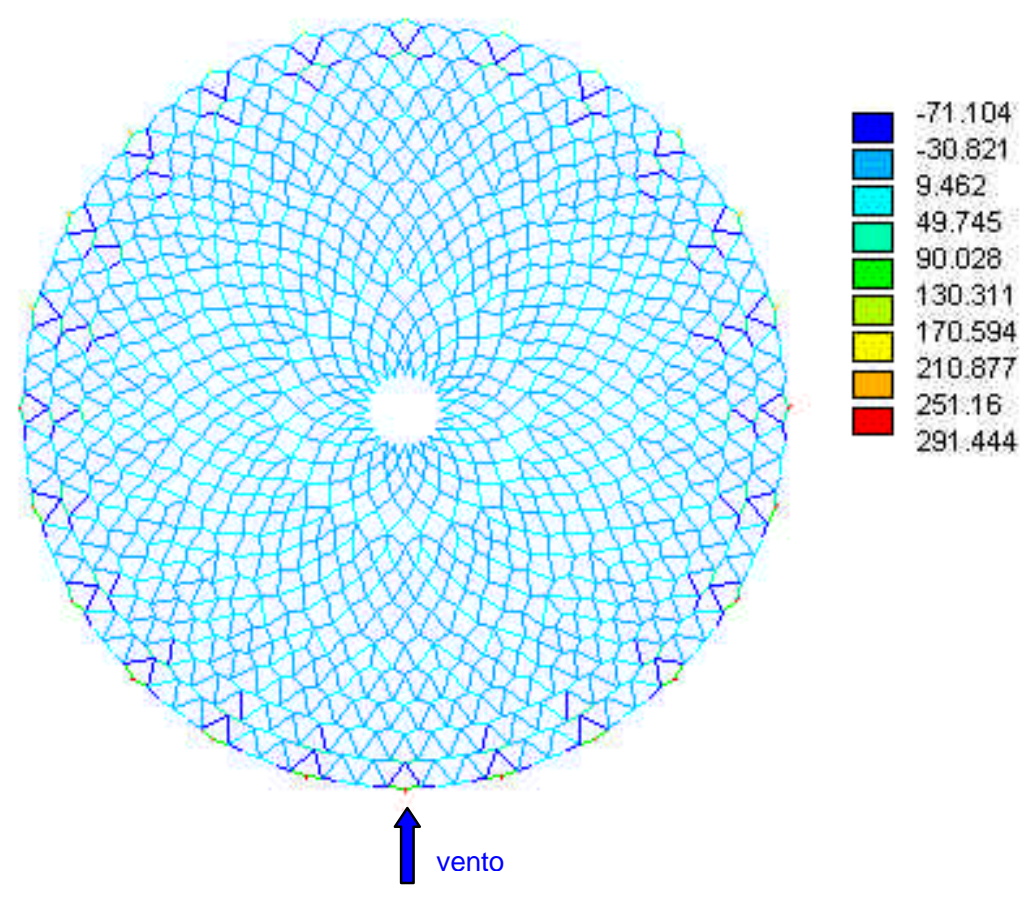

c) Esforços axiais para os elementos diagonais $(\mathrm{kN})$

Figura 5.7 - Esforços nos elementos da cúpula para combinação 2

\section{8 - Dimensionamento}

São apresentados o dimensionamento de algumas barras da estrutura, tendo em vista que o procedimento de cálculo é semelhante para o restante das barras e o que se pretende aqui, é apenas apresentar um breve roteiro de cálculo.

Para o dimensionamento das barras compara-se as solicitações nos elementos obtidas das combinações de ações, com as respectivas forças normais resistentes, escolhendo-se assim a seção transversal mais adequada.

Deve ser lembrado que neste dimensionamento não foi considerada possíveis reduções nas resistências das barras em função do amassamento das extremidades necessárias para confecção do nó típico. 
A figura 5.8 apresenta a posição das barras usadas para exemplificar o dimensionamento e a figura 5.9 indica as barras dimensionadas.

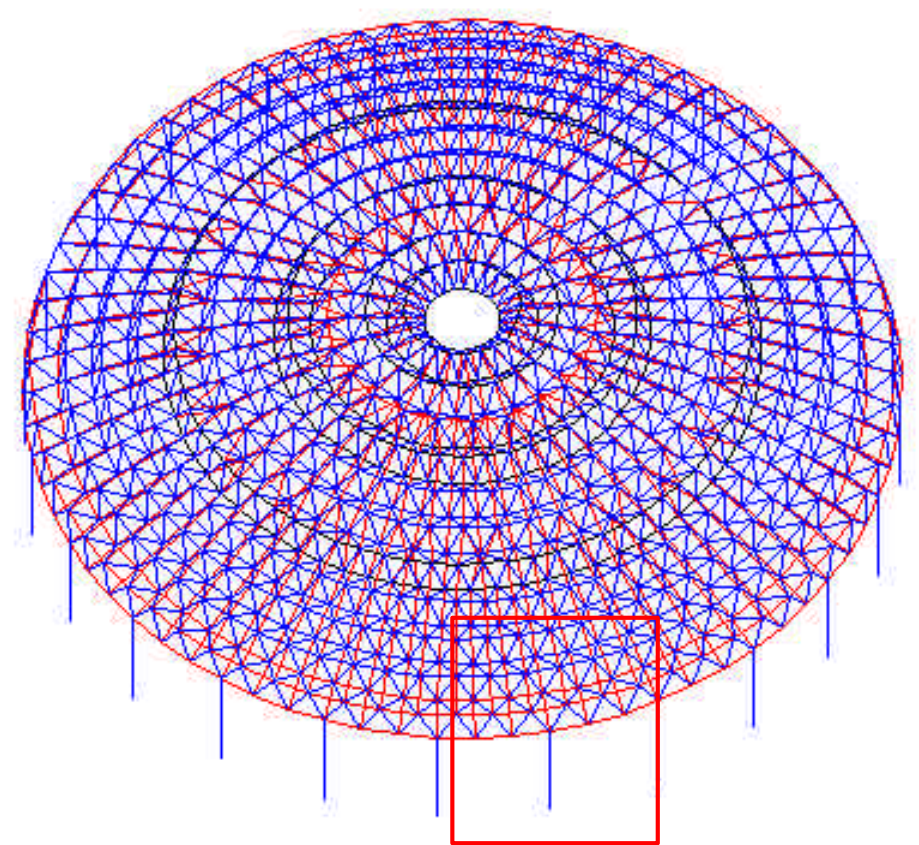

Figura 5.8 - Posição das barras usadas para o dimensionamento

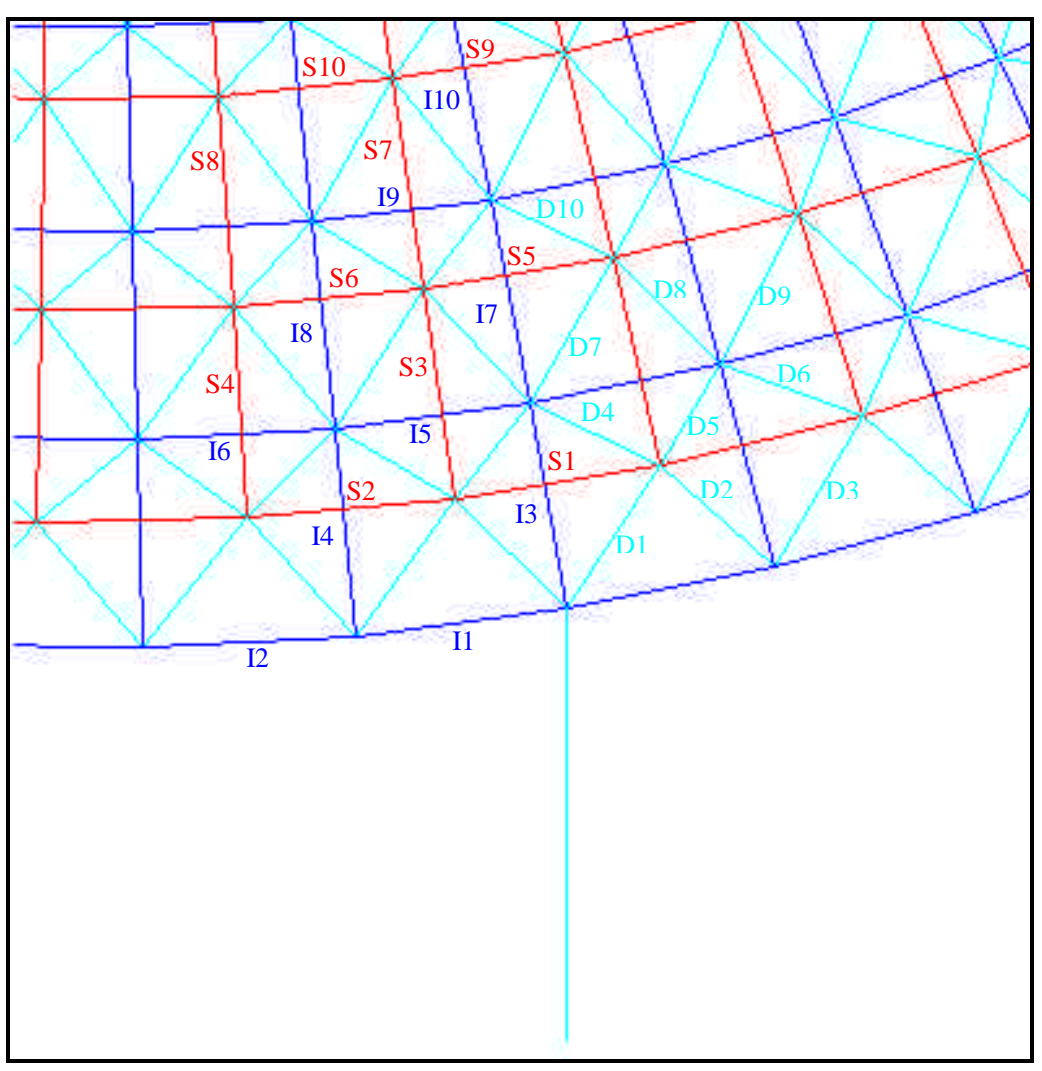

Figura 5.9 - Barras usadas para o dimensionamento 
A seguir é apresentada a tabela de dimensionamento de alguns dos elementos que constituem a cúpula: 
Tabela 5.2 - Dimensionamento de algumas barras da cúpula

\begin{tabular}{|c|c|c|c|c|c|c|c|c|c|c|c|c|c|c|c|c|c|c|c|c|c|}
\hline \multirow{3}{*}{ Posição } & \multirow{3}{*}{ Barras } & \multirow{3}{*}{$\begin{array}{c}\text { Compr. } \\
\text { (m) }\end{array}$} & \multirow{2}{*}{\multicolumn{2}{|c|}{ Esforços (KN) }} & \multicolumn{16}{|c|}{ Resistência de cálculo para barras de seção circular (KN) } & \multirow{3}{*}{$\begin{array}{l}\text { Seção } \\
\text { adotada }\end{array}$} \\
\hline & & & & & $F 60 x^{2}$ & $2,0 \mathrm{~mm}$ & F 76×2 &, $0 \mathrm{~mm}$ & \multicolumn{2}{|c|}{$\mathrm{F} 88,9 \times 2,25 \mathrm{~mm}$} & \multicolumn{2}{|c|}{$\mathrm{F} 101,6 \times 2,25 \mathrm{~mm}$} & \multicolumn{2}{|c|}{$\mathrm{F} 114,3 \times 2,25 \mathrm{~mm}$} & \multicolumn{2}{|c|}{$\mathrm{F} 127 \times 2,25 \mathrm{~mm}$} & \multicolumn{2}{|c|}{$\mathrm{F} 141,3 \times 2,25 \mathrm{~mm}$} & \multicolumn{2}{|c|}{$\mathrm{F} 152,4 \times 4,75 \mathrm{~mm}$} & \\
\hline & & & \begin{tabular}{|l|} 
Comb. 1 \\
\end{tabular} & Comb. 2 & $\overline{\mathrm{F}_{\mathrm{c}} \mathrm{N}_{\mathrm{c}}}$ & $\mathrm{F}_{\mathrm{t}} \mathrm{N}_{\mathrm{t}}$ & $\mathrm{F}_{\mathrm{c}} \mathrm{N}_{\mathrm{c}}$ & $\mathrm{F}_{\mathrm{t}} \mathrm{N}_{\mathrm{t}}$ & $\mathrm{F}_{\mathrm{c}} \mathrm{N}_{\mathrm{c}}$ & $\mathrm{F}_{\mathrm{t}} \mathrm{N}_{\mathrm{t}}$ & $\mathrm{F}_{\mathrm{c}} \mathrm{N}_{\mathrm{c}}$ & $\mathrm{F}_{\mathrm{t}} \mathrm{N}_{\mathrm{t}}$ & $\mathrm{F}_{\mathrm{c}} \mathrm{N}_{\mathrm{c}}$ & $\mathrm{F}_{\mathrm{t}} \mathrm{N}_{\mathrm{t}}$ & $\mathrm{F}_{\mathrm{c}} \mathrm{N}_{\mathrm{c}}$ & $\mathrm{F}_{\mathrm{t}} \mathrm{N}_{\mathrm{t}}$ & $\mathrm{F}_{\mathrm{c}} \mathrm{N}_{\mathrm{c}}$ & $\mathrm{F}_{\mathrm{t}} \mathrm{N}_{\mathrm{t}}$ & $\mathrm{F}_{\mathrm{c}} \mathrm{N}_{\mathrm{c}}$ & $\mathrm{F}_{\mathrm{t}} \mathrm{N}_{\mathrm{t}}$ & \\
\hline \multirow{10}{*}{$\begin{array}{l}\text { Camada } \\
\text { Superior }\end{array}$} & $\mathrm{S} 1$ & 4,47 & 57,0 & $-90,7$ & $-21,4$ & 81,9 & $-42,2$ & 104,6 & $-70,1$ & 137,7 & $-96,8$ & 158,0 & & & & & & & & & $\mathrm{~F} 101,6 \times 2,25 \mathrm{~mm}$ \\
\hline & S2 & 3,47 & 40,8 & $-45,5$ & $-21,4$ & 81,9 & $-42,2$ & 104,6 & $-70,1$ & 137,7 & & & & & & & & & & & $\mathrm{~F} 88,9 \times 2,25 \mathrm{~mm}$ \\
\hline & S3 & 3,58 & $-42,7$ & 80,3 & $-20,1$ & 81,9 & $-39,9$ & 104,6 & $-67,6$ & 137,7 & & & & & & & & & & & $\mathrm{~F} 88,9 \times 2,25 \mathrm{~mm}$ \\
\hline & S4 & 3,58 & $-25,0$ & 76,0 & $-20,1$ & 81,9 & $-39,9$ & 104,6 & & & & & & & & & & & & & $\mathrm{~F} 76 \times 2,2 \mathrm{~mm}$ \\
\hline & S5 & 3,18 & 30,1 & $-18,9$ & $-25,1$ & 81,9 & & & & & & & & & & & & & & & $\mathrm{~F} 60 \times 2,0 \mathrm{~mm}$ \\
\hline & S6 & 3,18 & 5,3 & 8,3 & $-25,1$ & 81,9 & & & & & & & & & & & & & & & $\mathrm{~F} 60 \times 2,0 \mathrm{~mm}$ \\
\hline & S7 & 3,58 & $-64,7$ & 124,7 & $-20,1$ & 81,9 & $-39,9$ & 104,6 & $-67,6$ & 137,7 & & & & & & & & & & & $\mathrm{~F} 88,9 \times 2,25 \mathrm{~mm}$ \\
\hline & $\mathrm{S} 8$ & 3,58 & $-42,8$ & 120,0 & $-20,1$ & 81,9 & $-39,9$ & \begin{tabular}{|l|}
104,6 \\
\end{tabular} & $-67,6$ & 137,7 & & & & & & & & & & & $\mathrm{~F} 88,9 \times 2,25 \mathrm{~mm}$ \\
\hline & S9 & 2,89 & 5,1 & 25,7 & $-29,5$ & 81,9 & & & & & & & & & & & & & & & $\mathrm{~F} 60 \times 2,0 \mathrm{~mm}$ \\
\hline & $S 10$ & 2,89 & $-7,1$ & 37,7 & $-29,5$ & 81,9 & & & & & & & & & & & & & & & $\mathrm{~F} 60 \times 2,0 \mathrm{~mm}$ \\
\hline \multirow{10}{*}{$\begin{array}{l}\text { Camada } \\
\text { Inferior }\end{array}$} & $\mathrm{I} 1$ & 3,52 & 80,7 & $-148,2$ & $-20,7$ & 81,9 & $-41,2$ & 104,6 & $-69,3$ & 137,7 & $-95,7$ & 158,0 & $-123,8$ & 178,2 & -149 & 198,2 & & & & & $\mathrm{~F} 127 \times 2,25 \mathrm{~mm}$ \\
\hline & 12 & 3,52 & 101,2 & $-160,0$ & $-20,7$ & 81,9 & $-41,2$ & 104,6 & $-69,3$ & 137,7 & $-95,7$ & 158,0 & $-123,8$ & 178,2 & -149 & 198,2 & $-235,1$ & 293,1 & & & $\mathrm{~F} 141,3 \times 2,25 \mathrm{~mm}$ \\
\hline & 13 & 3,50 & $-240,0$ & 253,0 & $-21,0$ & 81,9 & $-41,6$ & 104,6 & $-69,4$ & 137,7 & $-95,9$ & 158,0 & $-124,5$ & 178,2 & $-150,3$ & 198,2 & $-236,6$ & 293,1 & $-409,3$ & 495,5 & $\mathrm{~F} 152,4 \times 6,3 \mathrm{~mm}$ \\
\hline & 14 & 3,50 & $-11,1$ & 18,8 & $-21,0$ & 81,9 & & & & & & & & & & & & & & & $\mathrm{~F} 60 \times 2,0 \mathrm{~mm}$ \\
\hline & 15 & 3,25 & 68,2 & $-107,0$ & $-24,1$ & 81,9 & $-46,8$ & 104,6 & -77 & 137,7 & $-105,5$ & 158,0 & & & & & & & & & $\mathrm{~F} 101,6 \times 2,0 \mathrm{~mm}$ \\
\hline & 16 & 3,25 & 73,3 & $-112,0$ & $-24,1$ & 81,9 & $-76,8$ & 104,6 & -77 & 137,7 & $-105,5$ & 158,0 & $-131,7$ & 178,2 & & & & & & & $\mathrm{~F} 114,3 \times 2,25 \mathrm{~mm}$ \\
\hline & 17 & 3,50 & $-130,0$ & 114,8 & $-21,0$ & 81,9 & $-41,6$ & 104,6 & $-69,2$ & 137,7 & $-95,9$ & 158,0 & & 178,2 & $-150,3$ & 198,2 & & & & & $\mathrm{~F} 127 \times 2,25 \mathrm{~mm}$ \\
\hline & 18 & 3,50 & $-28,7$ & 15,5 & $-21,0$ & 81,9 & $-41,6$ & 104,6 & & & & & & & & & & & & & $\mathrm{~F} 76 \times 2,2 \mathrm{~mm}$ \\
\hline & 19 & 2,97 & 30,6 & $-38,3$ & $-28,0$ & 81,9 & $-53,3$ & 104,6 & & & & & & & & & & & & & $\mathrm{~F} 76 \times 2,2 \mathrm{~mm}$ \\
\hline & 110 & 3,50 & $-74,6$ & 47,5 & $-21,0$ & 81,9 & $-41,6$ & 104,6 & $-69,2$ & 137,7 & $-95,9$ & 158,0 & & & & & & & & & $\mathrm{~F} 101,6 \times 2,0 \mathrm{~mm}$ \\
\hline \multirow{10}{*}{ Diagonais } & $\overline{\mathrm{D} 1}$ & 3,19 & $-68,0$ & 109,4 & $-25,1$ & 81,9 & $-48,4$ & 104,6 & $-79,7$ & 137,7 & & & & & & & & & & & $\mathrm{~F} 88,9 \times 2,25 \mathrm{~mm}$ \\
\hline & D2 & 3,19 & 22,4 & $-33,7$ & $-25,1$ & 81,9 & $-48,4$ & \begin{tabular}{|l|}
104,6 \\
\end{tabular} & & & & & & & & & & & & & $\mathrm{~F} 76 \times 2,0 \mathrm{~mm}$ \\
\hline & D3 & 3,19 & $-15,0$ & 24,2 & $-25,1$ & 81,9 & & & & & & & & & & & & & & & $\mathrm{~F} 60 \times 2,0 \mathrm{~mm}$ \\
\hline & D4 & 3,15 & 48,6 & $-62,6$ & $-25,1$ & 81,9 & $-49,0$ & 104,6 & $-80,55$ & 137,7 & & & & & & & & & & & $\mathrm{~F} 88,9 \times 2,25 \mathrm{~mm}$ \\
\hline & D5 & 3,15 & $-16,7$ & 3,0 & $-25,5$ & 81,9 & & & & & & & & & & & & & & & $\mathrm{~F} 60 \times 2,0 \mathrm{~mm}$ \\
\hline & $\mathrm{D} 6$ & 3,15 & 8,2 & $-16,2$ & $-25,5$ & 81,9 & & & & & & & & & & & & & & & $\mathrm{~F} 60 \times 2,0 \mathrm{~mm}$ \\
\hline & D7 & 3,11 & $-51,1$ & 65,8 & $-26,1$ & 81,9 & & 104,6 & & & & & & & & & & & & & $\mathrm{~F} 76 \times 2,0 \mathrm{~mm}$ \\
\hline & $\mathrm{D} 8$ & 3,11 & 25,2 & $-15,8$ & $-26,1$ & 81,9 & & & & & & & & & & & & & & & $\mathrm{~F} 60 \times 2,0 \mathrm{~mm}$ \\
\hline & D9 & 3,11 & $-11,6$ & 24,9 & $-26,1$ & 81,9 & & & & & & & & & & & & & & & $\mathrm{~F} 60 \times 2,0 \mathrm{~mm}$ \\
\hline & D10 & 3,08 & 23,8 & $-29,4$ & $-26,5$ & 81,9 & & & & & & & & & & & & & & & $\mathrm{~F} 60 \times 2,0 \mathrm{~mm}$ \\
\hline
\end{tabular}

Obs.1 - Os sinais negativos indicam compressão 


\section{9 - Resultados}

As figuras seguintes apresentam os resultados de deslocamentos para cúpula analisada, para diferentes combinações de ações com seus valores nominais.
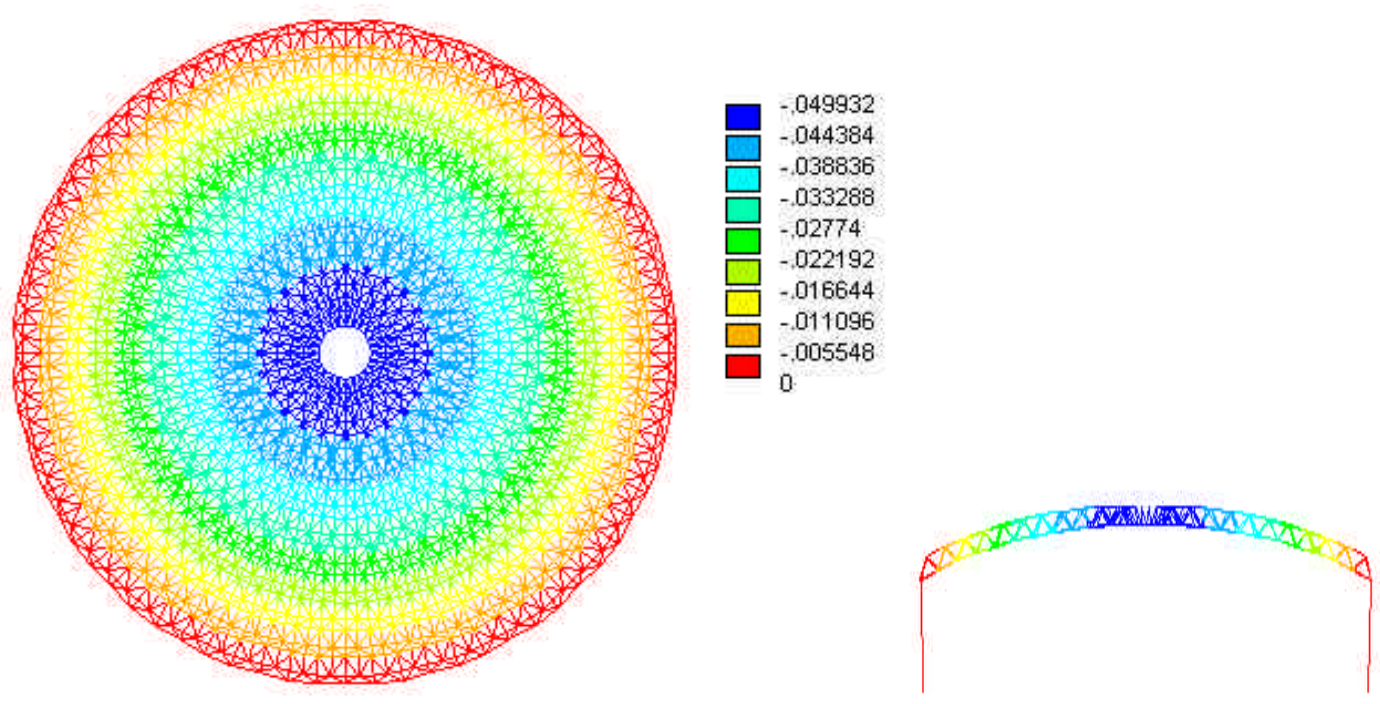

Figura 5.10 - Deslocamentos verticais devido ao peso próprio (m)
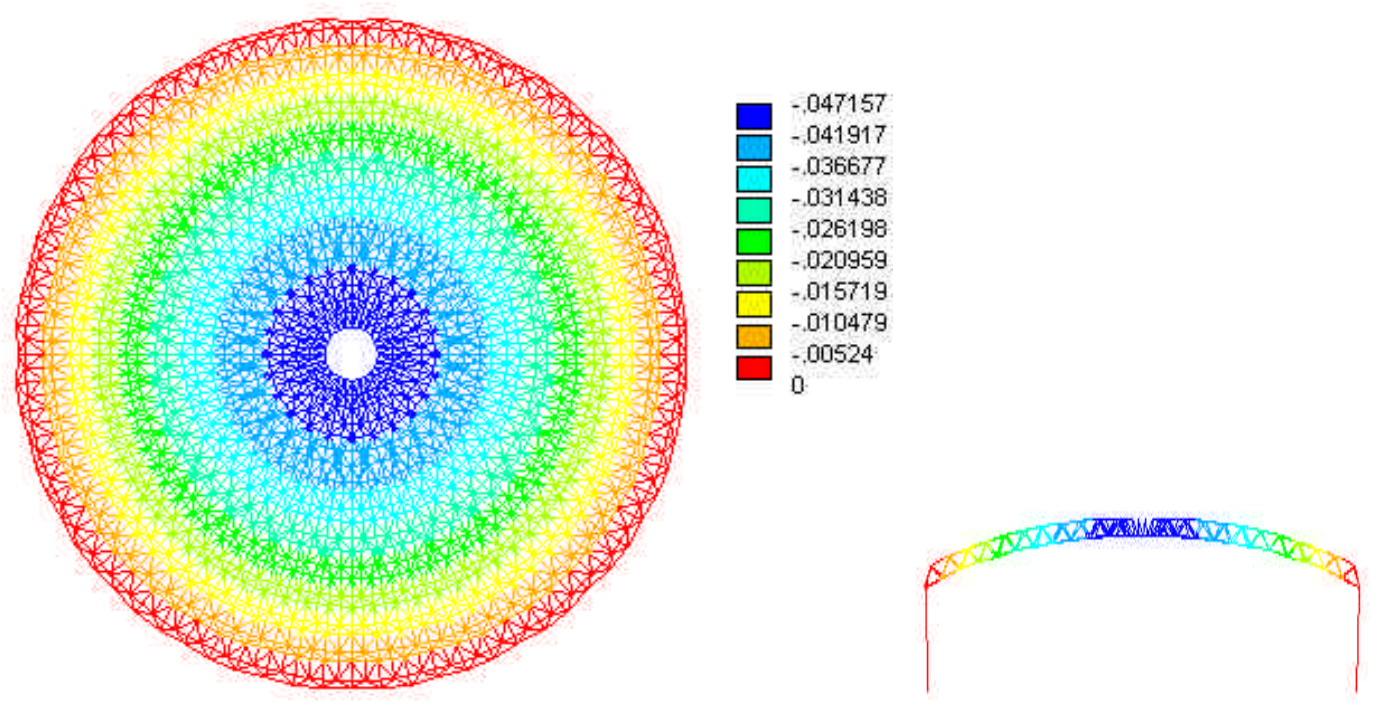

Figura 5.11 - Deslocamentos verticais devido à sobrecarga $(\mathrm{m})$ 


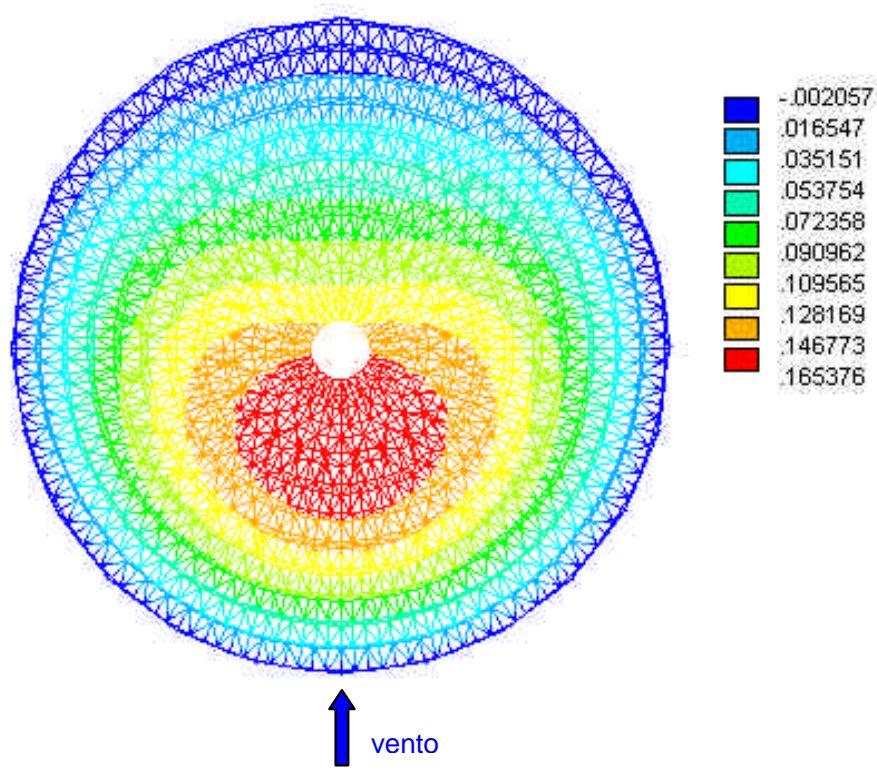

Corte paralelo a direção do vento

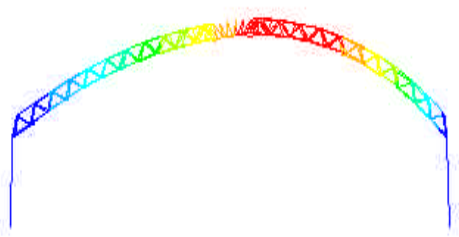

Figura 5.12 - Deslocamentos verticais devido ao vento (m)
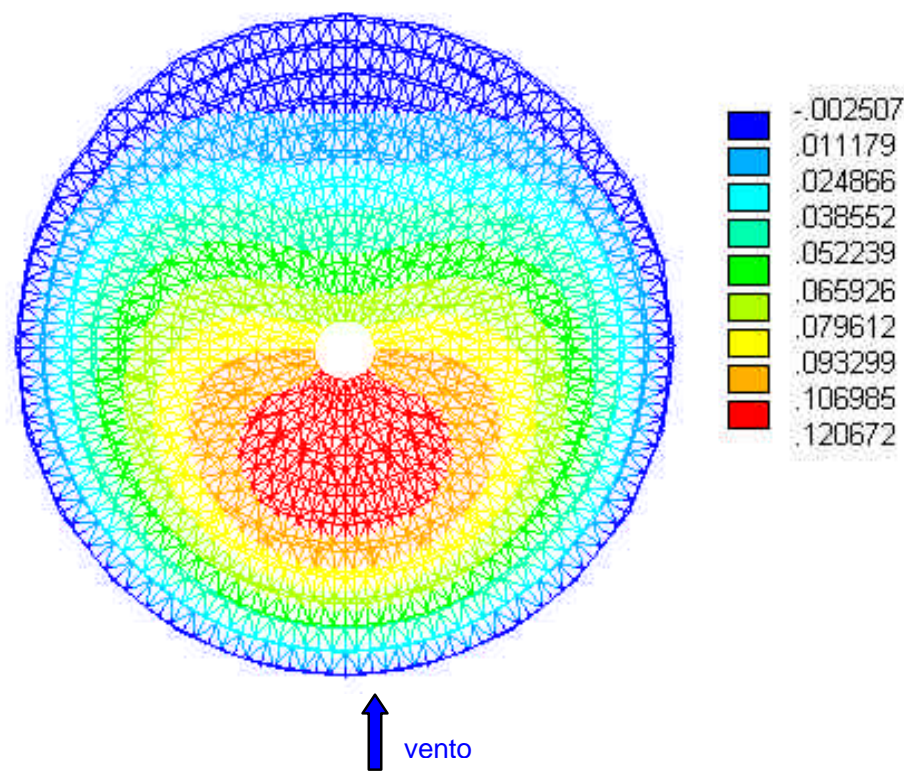

Corte paralelo a direção do vento

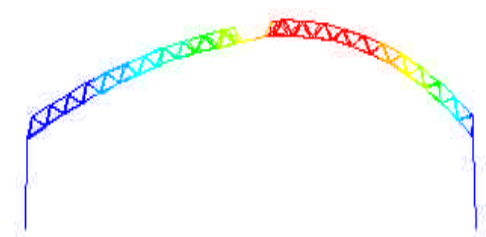

Figura 5.13 - Deslocamentos devido ao peso próprio + vento (m)

Observando os valores de deslocamentos apresentados nas figuras anteriores, percebe-se que as estruturas em forma de cúpula apresentam pequenos deslocamentos, porém, são sensíveis as condições de vinculação, ou seja, dependem da inércia dos pilares a que estão vinculadas. Para este exemplo, os deslocamentos são inferiores ao máximo permitido por norma para sobrecarga agindo sobre a estrutura $(L / 400)$. 


\subsection{0- Estudo da ruína progressiva}

Sabe-se que o colapso das estruturas compostas por elementos tubulares, como as cúpulas, é governado, predominantemente, pela flambagem sucessiva dos elementos comprimidos, muitas vezes influenciados pelo comportamento do nó.

O objetivo deste item é simular o comportamento de uma cúpula quando ocorre a falha de elementos que compõem sua malha. Esta falha pode ser originada devido a um inadequado dimensionamento dos elementos ou problemas de montagem.

Este estudo é feito em duas regiões diferentes da cúpula que podem ser vistas na figura 5.14 .

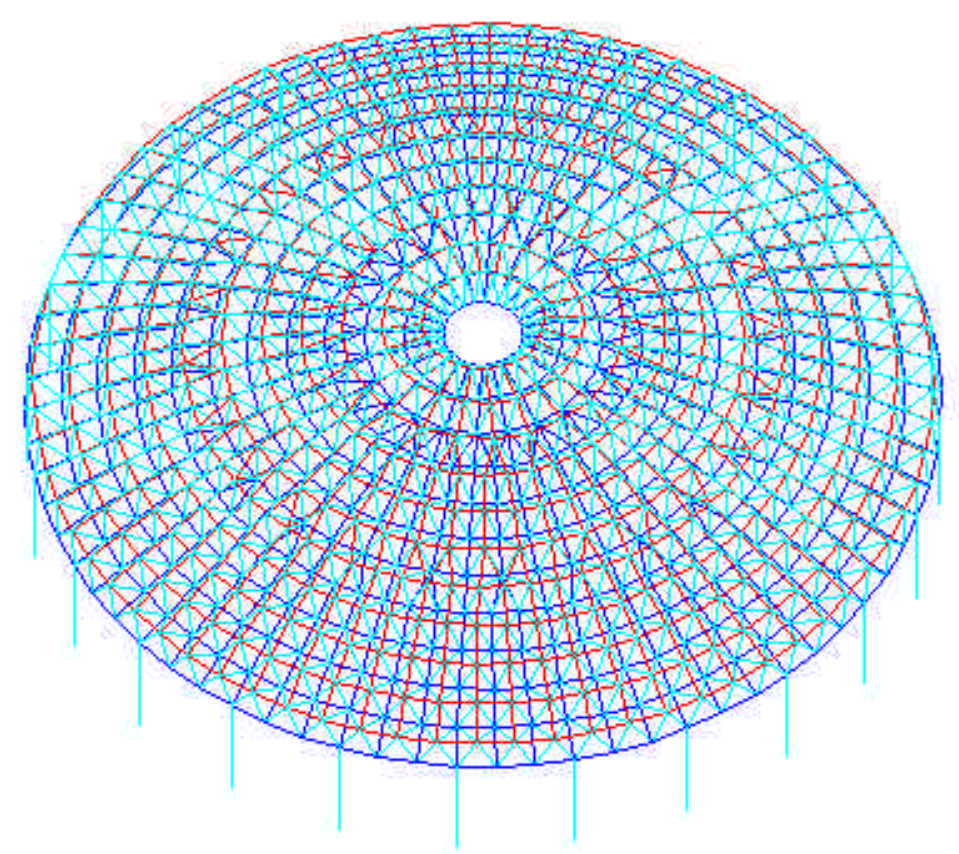

a) Vista geral da cúpula 


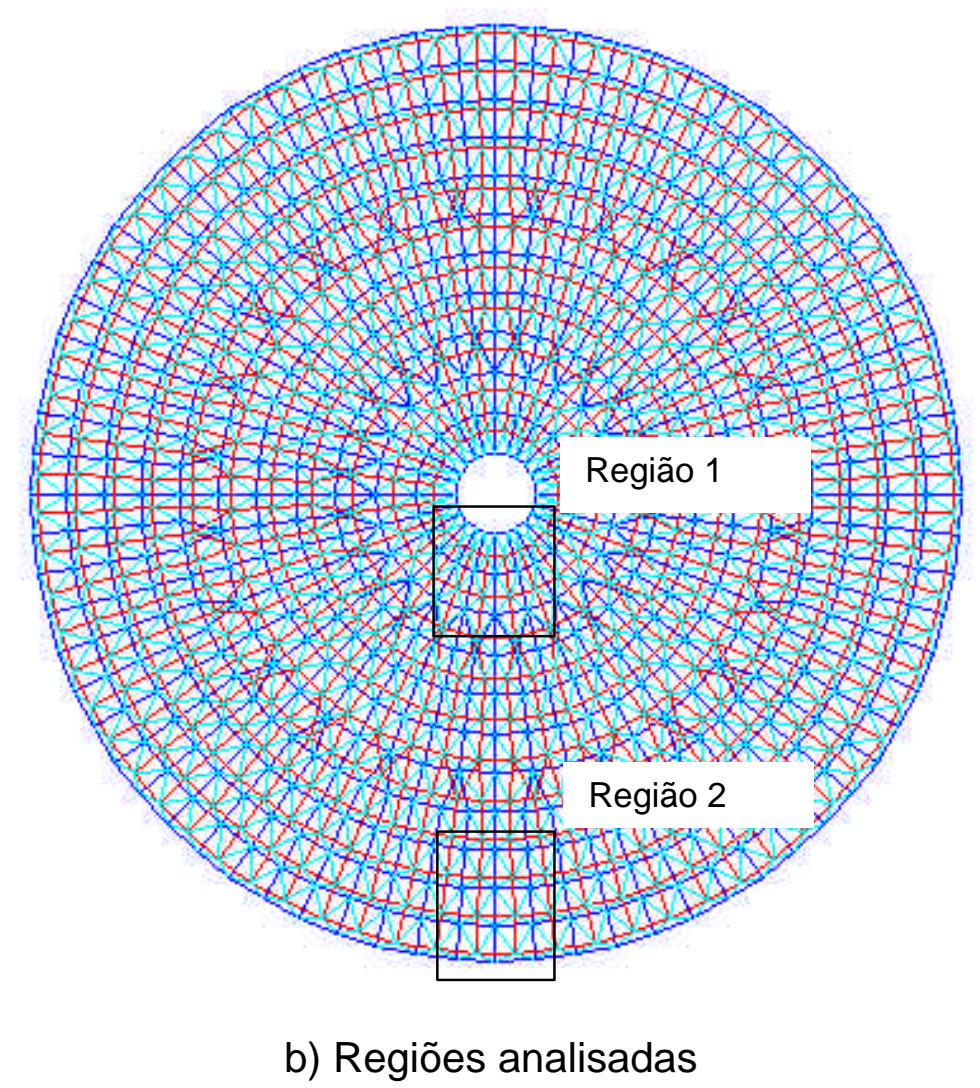

Figura 5.14 - Detalhe da estrutura com as regiões estudadas

Para melhor compreender o comportamento de cada região analisada durante a simulação da ruína progressiva, faz-se uma medição de deslocamento verticais para cada etapa da simulação, em pontos prédefinidos na estrutura. Estes resultados são apresentados em tabelas com um breve comentário sobre o comportamento da estrutura.

Os pontos em que foram obtidos os deslocamentos verticais podem ser vistos na figura 5.15 , para cada região analisada. 


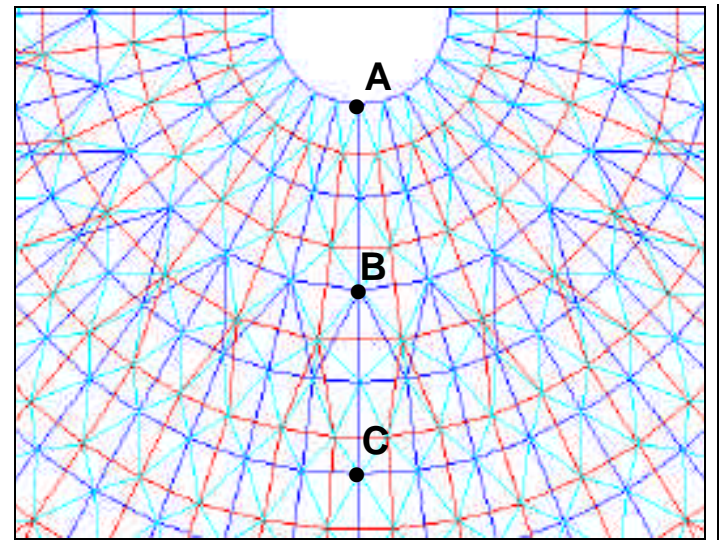

a) Região 1

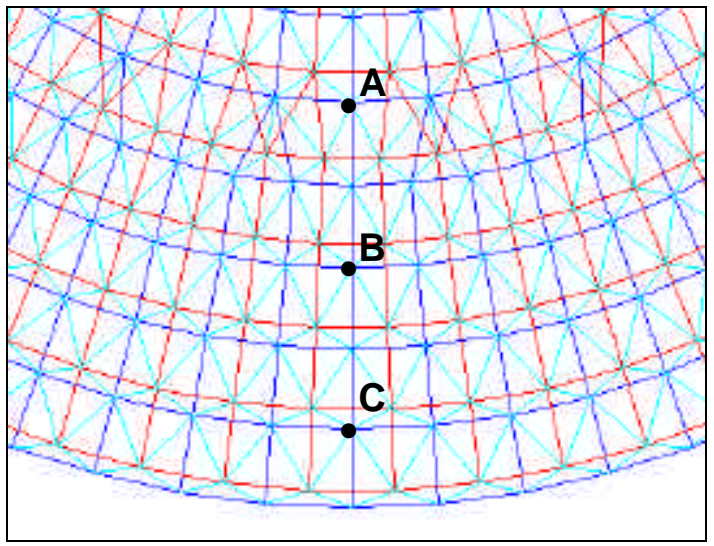

b) Região 2

Figura 5.15 - Pontos de medição do deslocamento

5.10.1- Análise da região 1 considerando o peso próprio+sobrecarga

Nesta primeira etapa da simulação da ruína progressiva, a cúpula foi analisada com todos os elementos que a constitui a fim de conhecermos os esforços axiais em cada elemento, bem como suas respectivas seções transversais.

A figura 5.16 apresenta os resultados de esforços axiais e deslocamentos para alguns elementos da região 1 da cúpula considerando os valores nominais para as ações. 


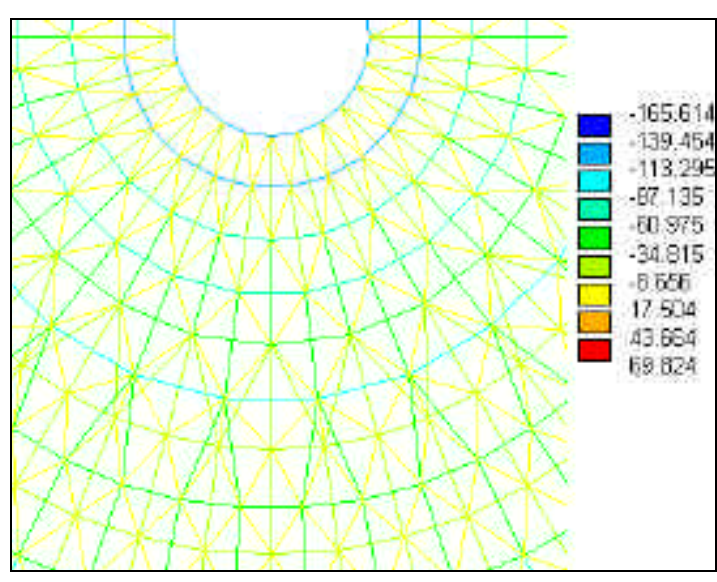

a) Esforços axiais ( $\mathrm{kN})$

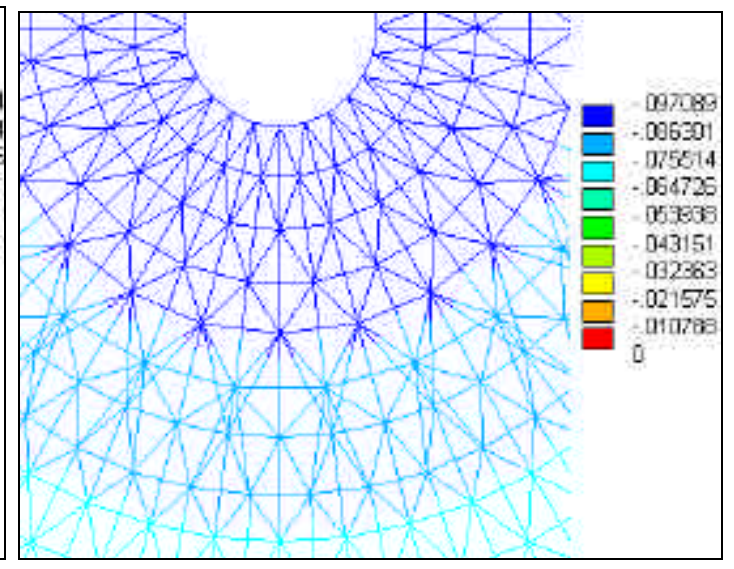

b) Deslocamentos verticais $(\mathrm{m})$

Figura 5.16 - Esforços e deslocamentos da região 1

Para simularmos uma possível falha na estrutura devido à problemas na montagem de algum elemento ou até mesmo ruptura pelo dimensionamento incorreto do mesmo, a estrutura foi analisada retirando uma barra do anel da malha superior.

A figura 5.17 apresenta a redistribuição de esforços nos elementos e os novos deslocamentos da estrutura.

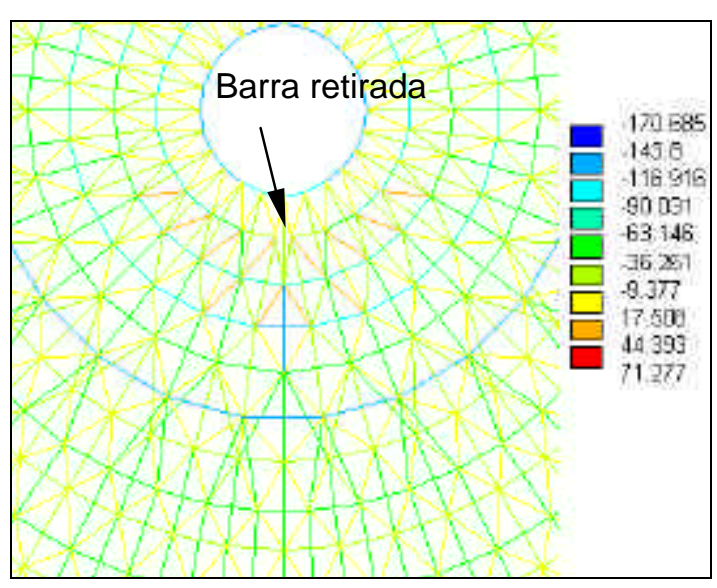

a) Esforços axiais $(\mathrm{kN})$

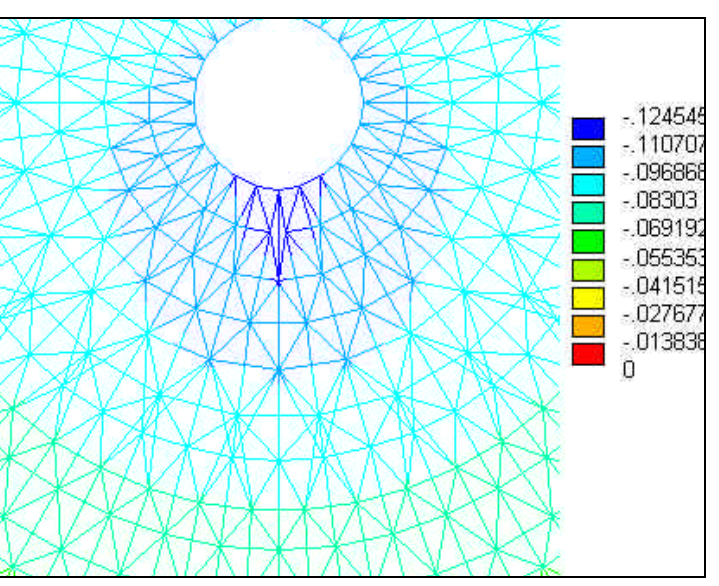

b) Deslocamentos verticais ( $\mathrm{m}$ )

Figura 5.17 - Esforços e deslocamentos após a retirada de uma barra 
Pela figura 5.17 percebe-se uma redistribuição de esforços para os elementos vizinhos ao elemento retirado. Esta redistribuição faz com que novos elementos atinjam a ruína já que a seção para qual foram dimensionados não é suficiente para receber os novos esforços que lhe são conferidos.

Em vista disto, nesta nova etapa, retirou-se todos os elementos que foram a ruína, ou seja, elementos cujos valores de esforços normais ultrapassam os esforços normais resistentes, e uma nova análise da estrutura foi realizada.

Os novos esforços e deslocamentos, bem como um detalhe da ruína localizada podem ser vistos nas figuras 5.18 e 5.19 , respectivamente.

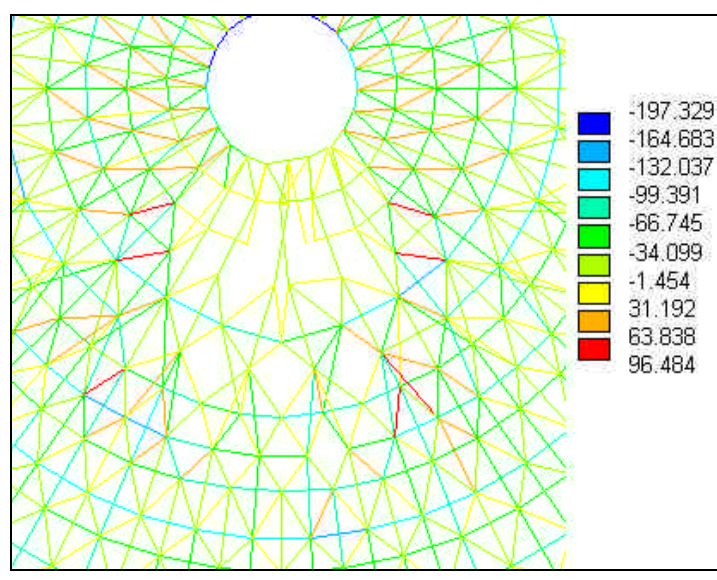

a) Esforços axiais (kN)

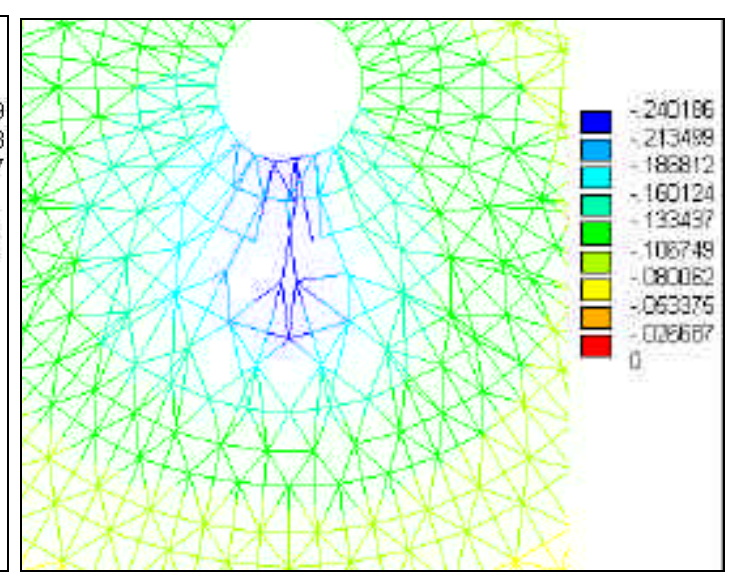

b) Deslocamentos verticais $(m)$

Figura 5.18- Esforços e deslocamentos após a retirada das barras rompidas 


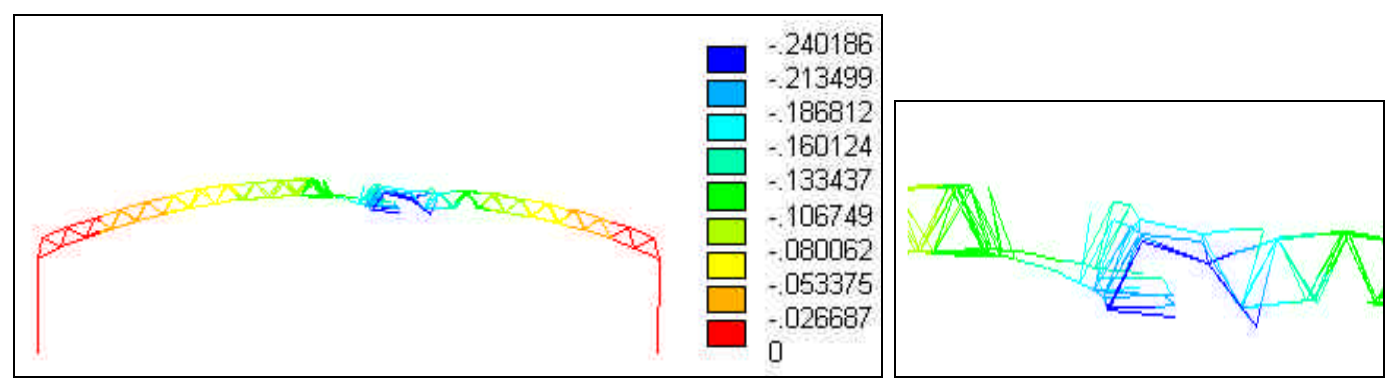

a) Deslocamentos verticais $(m)$

b) Detalhe da ruína

Figura 5.19 - Detalhe da ruína na região analisada

Novamente temos uma redistribuição de esforços, como apresenta a figura 5.18, podendo causar a ruína de outros elementos. Esta seqüência, dependendo da região em que ocorre, pode levar a estrutura a uma ruína progressiva podendo terminar em um colapso parcial ou global da estrutura.

Pela figura 5.19 pode-se observar um detalhe localizado do colapso parcial na região em que foram retiradas as barras.

A tabela 5.3 apresenta os deslocamentos no decorrer da simulação em função do número de barras retiradas.

Tabela 5.3 - Deslocamentos nodais

\begin{tabular}{|c|c|c|c|}
\hline \multirow{2}{*}{$\begin{array}{l}\text { Posição } \\
\text { de leitura }\end{array}$} & \multicolumn{3}{|c|}{ Deslocamentos (m) } \\
\cline { 2 - 4 } & \multicolumn{2}{|c|}{ Número de barras retiradas na região } \\
\cline { 2 - 4 } & Nenhuma & 1 barra & 48 barras \\
\hline A & -0.097 & -0.125 & -0.230 \\
\hline B & -0.088 & -0.099 & -0.229 \\
\hline C & -0.075 & -0.079 & -0.111 \\
\hline
\end{tabular}

Pelos resultados apresentados na tabela 5.3 observa-se que para retirada de apenas uma barra a estrutura não apresenta aumento significativo nos deslocamentos ao passo que, na etapa seguinte, em que foram retiradas várias barras, os deslocamentos nos pontos $\mathrm{A}$ e $\mathrm{B}$, por estarem mais próximos da região afetada, praticamente dobraram. 
As análise apresentadas a seguir possuem os mesmos procedimentos que as anteriores porém, com outras combinações para as ações bem como outra região analisada.

5.10.2- Análise da região 1 considerando o peso próprio+vento

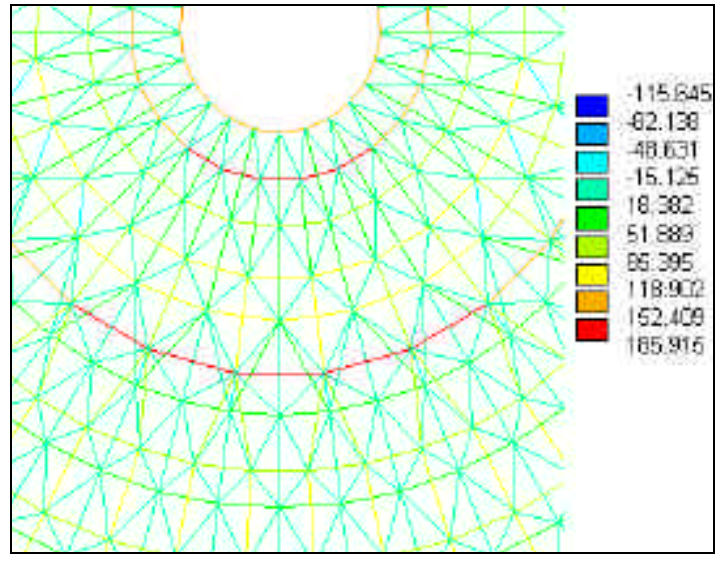

a) Esforços axiais (kN)

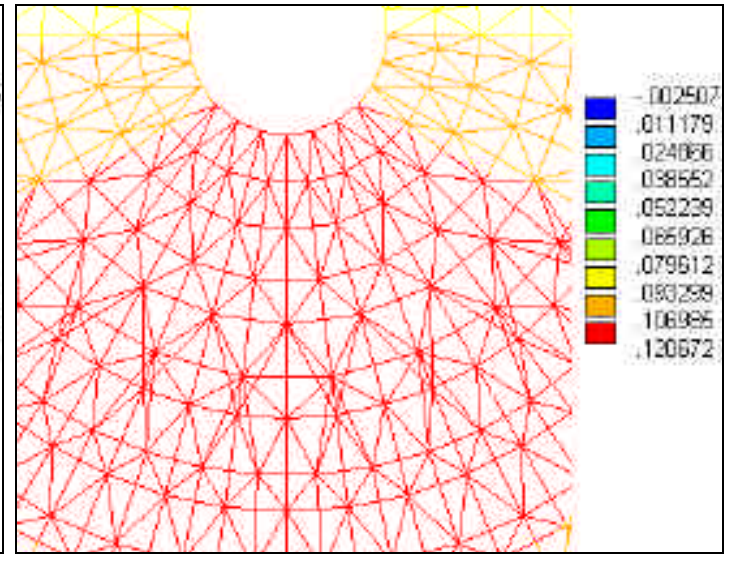

b) Deslocamentos verticais $(m)$

Figura 5.20 - Esforços e deslocamentos da região 1

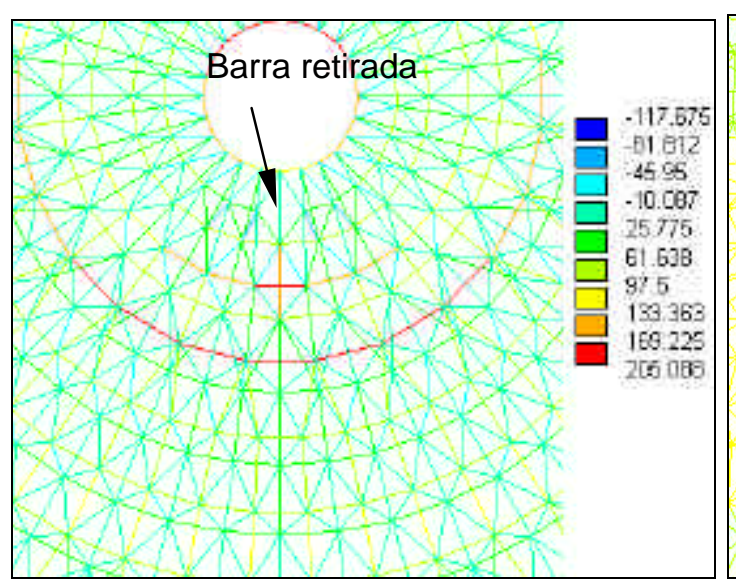

a) Esforços axiais $(\mathrm{kN})$

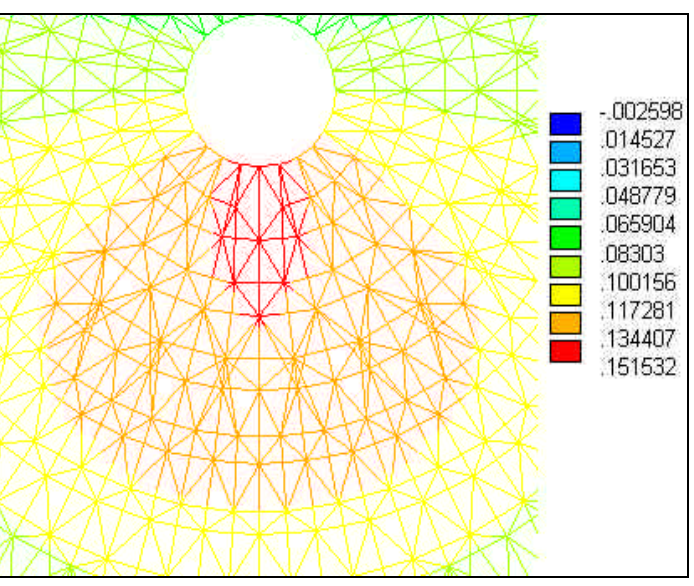

b) Deslocamentos verticais $(m)$

Figura 5.21 - Esforços e deslocamentos após a retirada de uma barra 


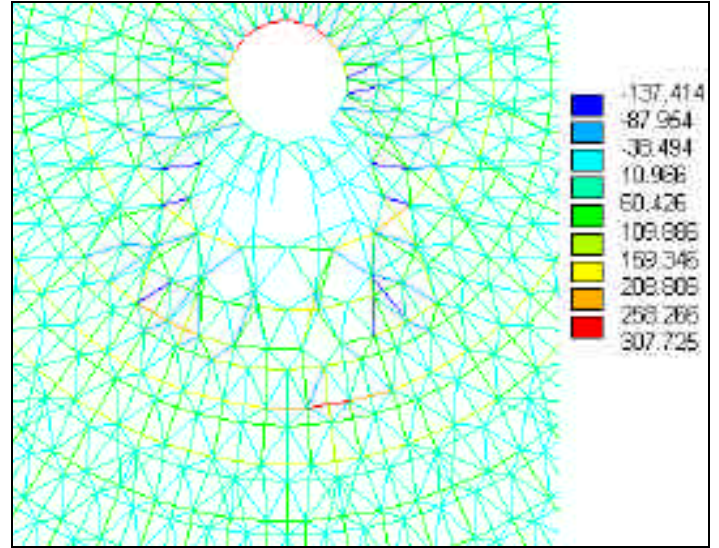

a) Esforços axiais $(\mathrm{kN})$

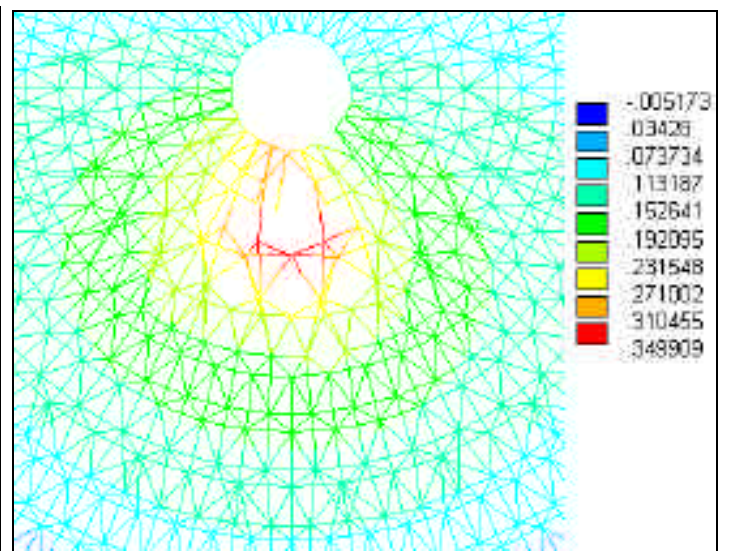

b) Deslocamentos verticais $(\mathrm{m})$

Figura 5.22- Esforços e deslocamentos após a retirada das barras rompidas

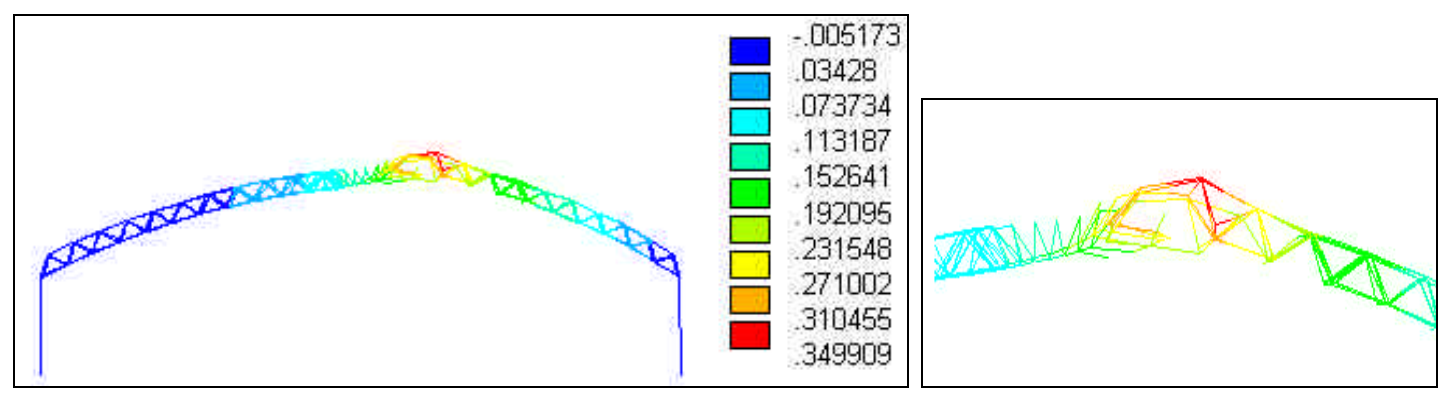

a) Deslocamentos verticais $(\mathrm{m})$

b) Detalhe da ruína

Figura 5.23 - Detalhe da ruína na região analisada

Tabela 5.4 - Deslocamentos nodais

\begin{tabular}{|c|c|c|c|}
\hline \multirow{2}{*}{$\begin{array}{l}\text { Posição } \\
\text { de leitura }\end{array}$} & \multicolumn{3}{|c|}{ Deslocamentos (m) } \\
\cline { 2 - 4 } & \multicolumn{2}{|c|}{ Número de barras retiradas na região } \\
\cline { 2 - 4 } & Nenhuma & 1 barra & 48 barras \\
\hline A & 0.113 & 0.152 & 0.297 \\
\hline B & 0.121 & 0.135 & 0.339 \\
\hline C & 0.118 & 0.123 & 0.184 \\
\hline
\end{tabular}

Observando os valores da tabela 5.4, percebemos o aumento significativo nos deslocamentos dos pontos $\mathrm{A}$ e $\mathrm{B}$, quando várias barras são 
retiradas da estrutura. Este aumento se deve à perda de rigidez nesta região, principalmente no ponto $\mathrm{B}$, localizado na região da ruína localizada.

5.10.3- Análise da região 2 considerando o peso próprio+sobrecarga

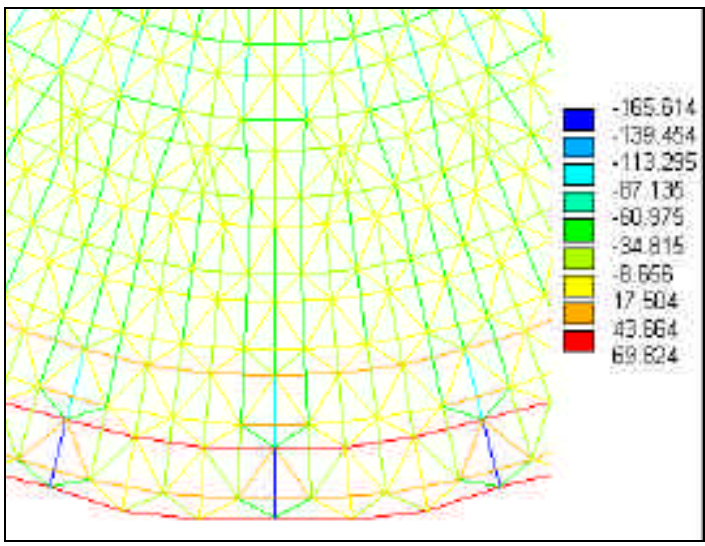

a) Esforços axiais (kN)

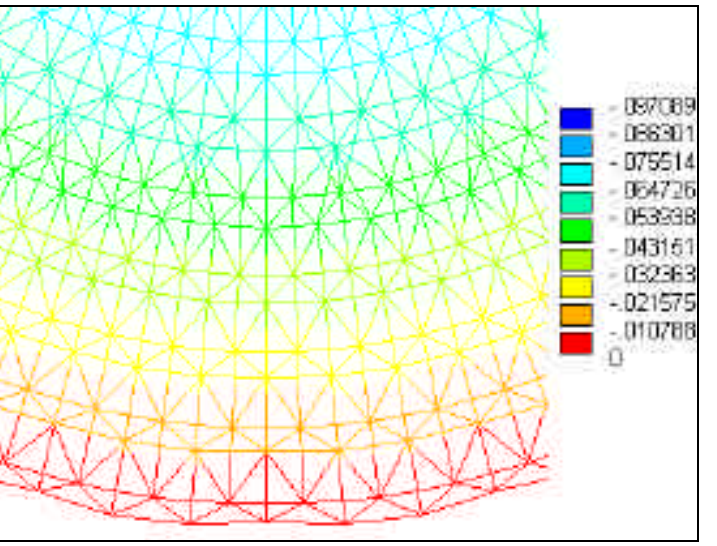

b) Deslocamentos verticais $(\mathrm{m})$

Figura 5.24 - Esforços e deslocamentos da região 2

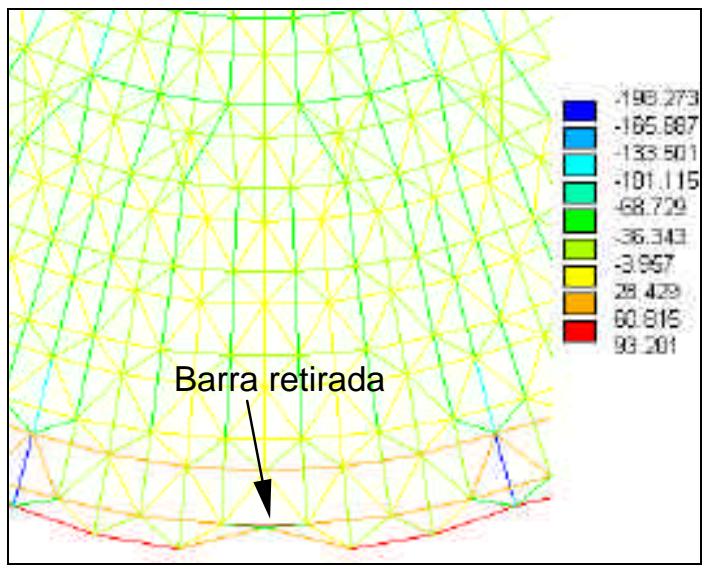

a) Esforços axiais $(\mathrm{kN})$

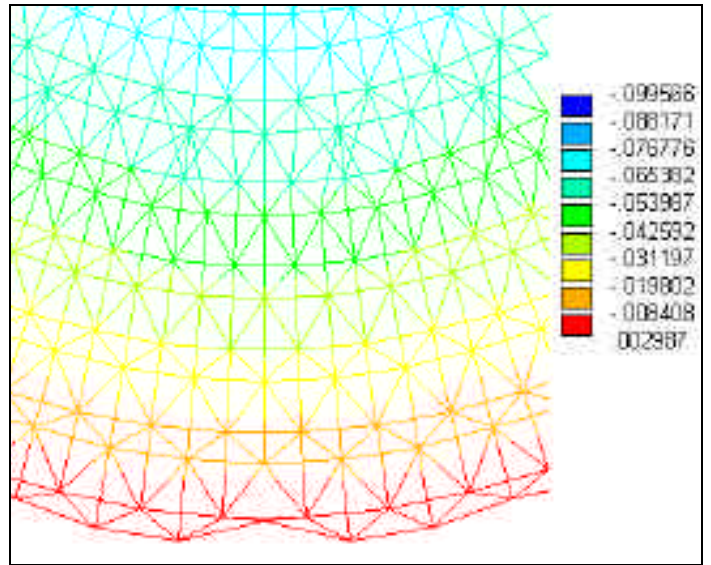

b) Deslocamentos verticais $(\mathrm{m})$

Figura 5.25 - Esforços e deslocamentos após a retirada de uma barra 


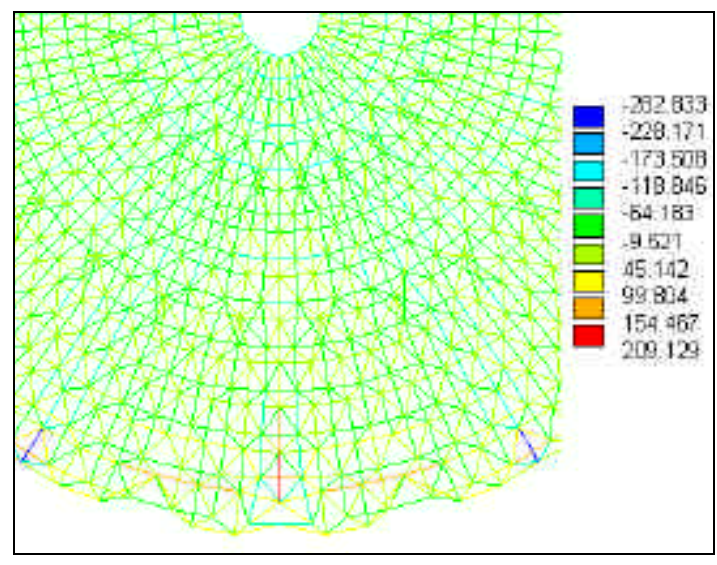

a) Esforços axiais (kN)

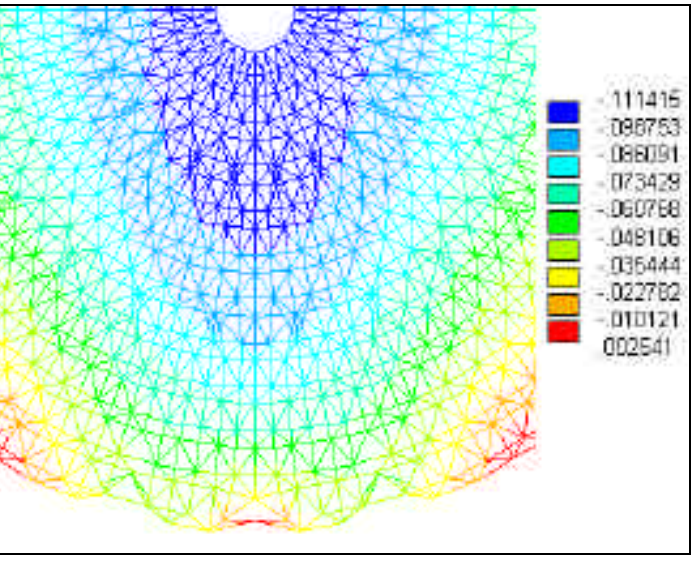

b) Deslocamentos verticais $(m)$

Figura 5.26- Esforços e deslocamentos após a retirada das barras rompidas

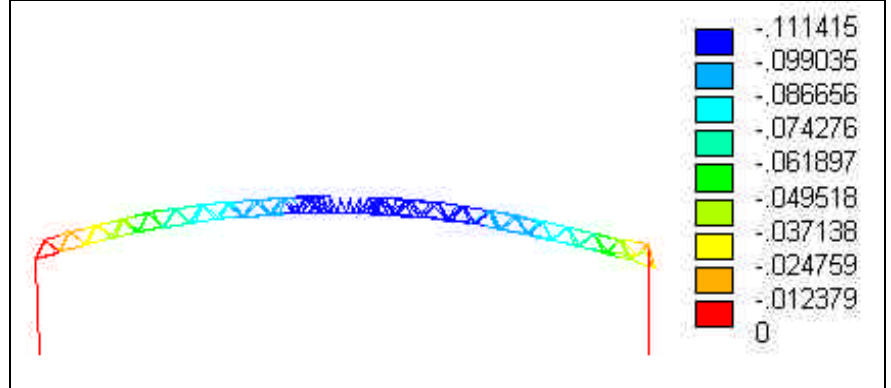

a) Deslocamentos verticais (m)

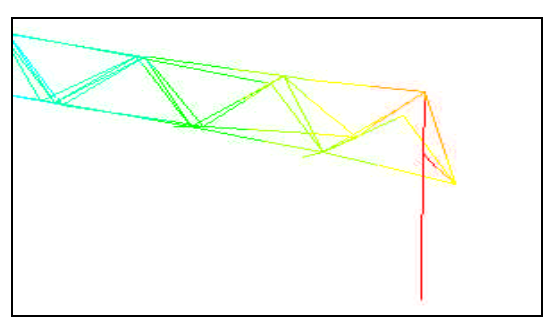

b) Detalhe da ruína

Figura 5.27 - Detalhe da ruína na região analisada

Tabela 5.5 - Deslocamentos nodais

\begin{tabular}{|c|c|c|c|}
\hline \multirow{2}{*}{$\begin{array}{l}\text { Posição } \\
\text { de leitura }\end{array}$} & \multicolumn{3}{|c|}{ Deslocamentos (m) } \\
\cline { 2 - 4 } & \multicolumn{2}{|c|}{ Número de barras retiradas na região } \\
\cline { 2 - 4 } & Nenhuma & 1 barra & 14 barras \\
\hline A & -0.058 & -0.062 & -0.092 \\
\hline B & -0.036 & -0.041 & -0.074 \\
\hline C & -0.011 & -0.012 & -0.028 \\
\hline
\end{tabular}

Diferentemente do que acontece com os deslocamentos na região próxima ao anel central, visto nas tabelas 5.3 e 5.4, na região próxima ao 
apoio os aumentos pela retirada das barras são menos significativos, como pode ser visto na tabela 5.5 .

5.10.4- Análise da região 2 considerando o peso próprio+vento

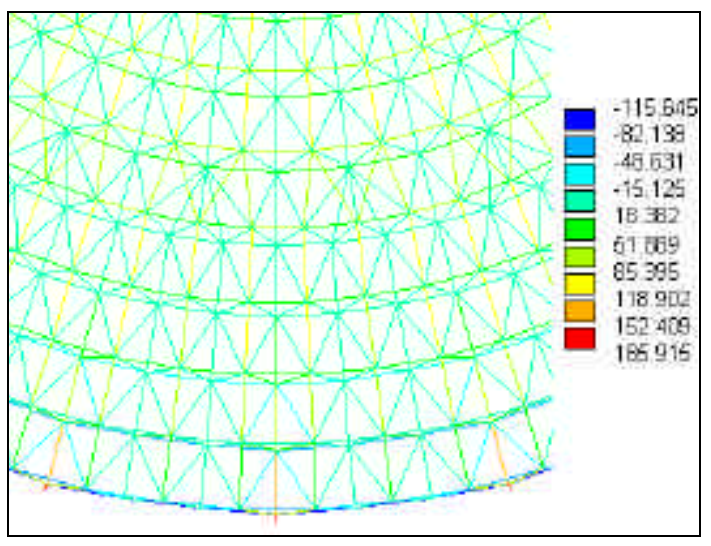

a) Esforços axiais $(\mathrm{kN})$

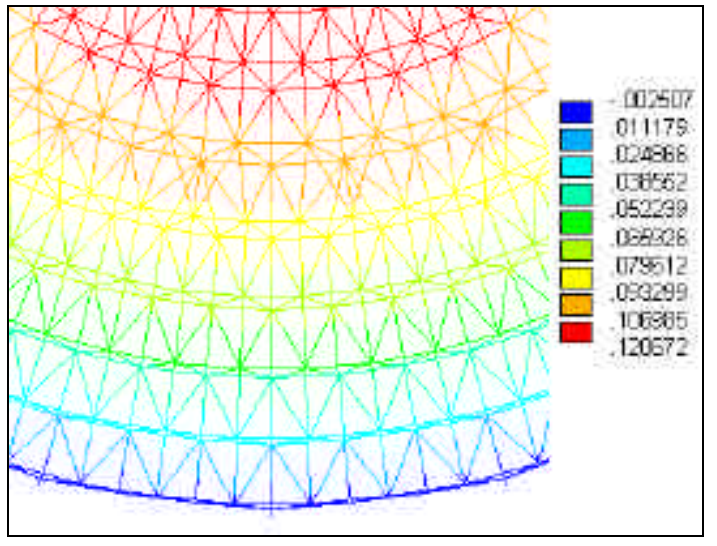

b) Deslocamentos verticais (m)

Figura 5.28 - Esforços e deslocamentos da região 2

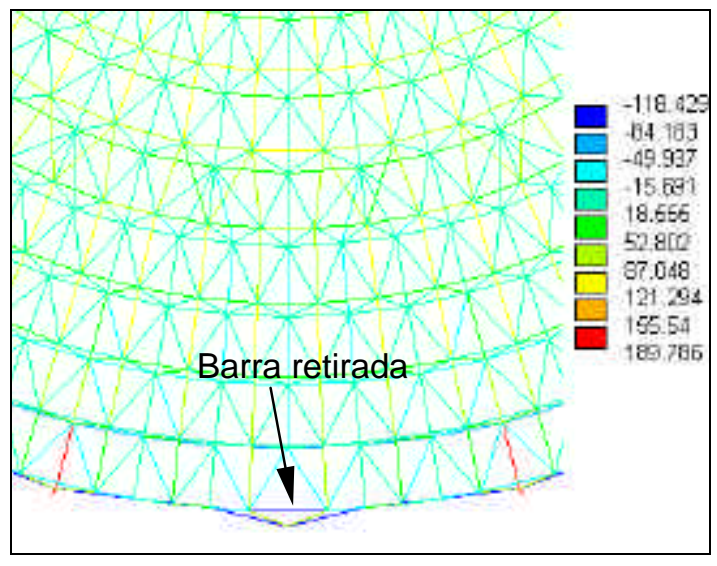

a) Esforços axiais (kN)

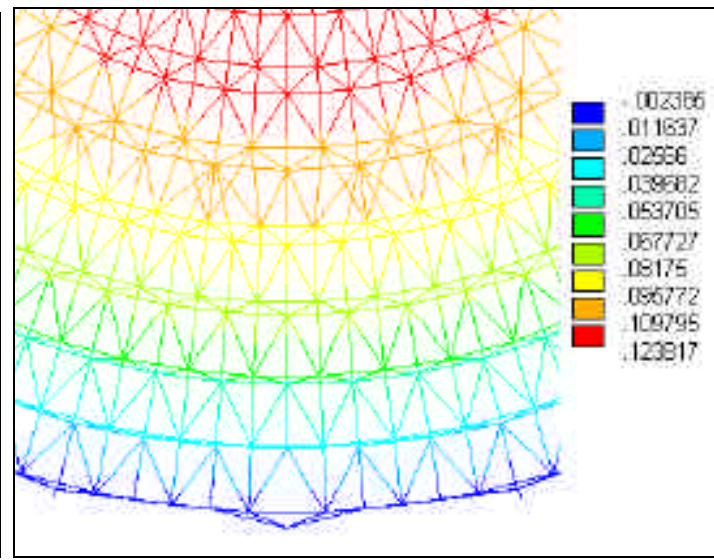

b) Deslocamentos verticais $(\mathrm{m})$

Figura 5.29 - Esforços e deslocamentos após a retirada de uma barra 


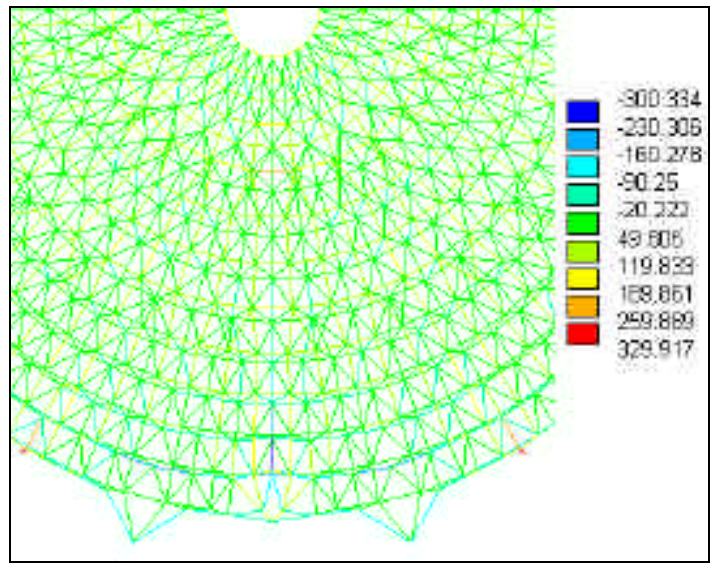

a) Esforços axiais $(\mathrm{kN})$

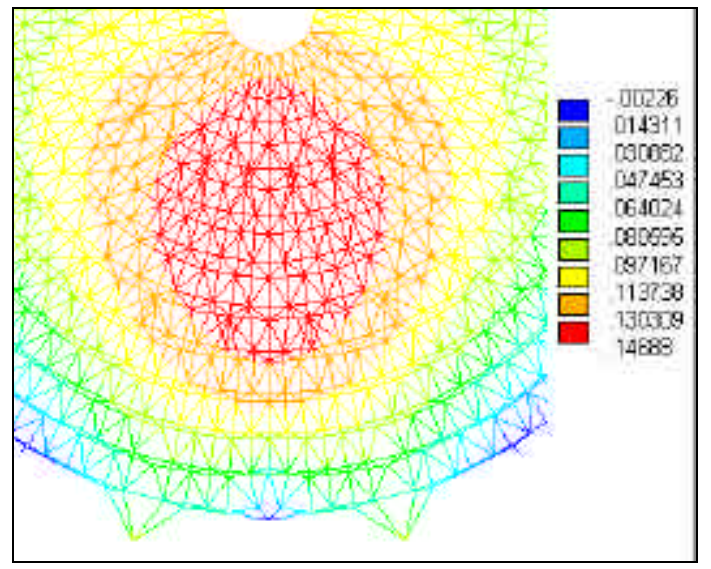

b) Deslocamentos verticais ( $\mathrm{m}$ )

Figura 5.30- Esforços e deslocamentos após a retirada das barras rompidas

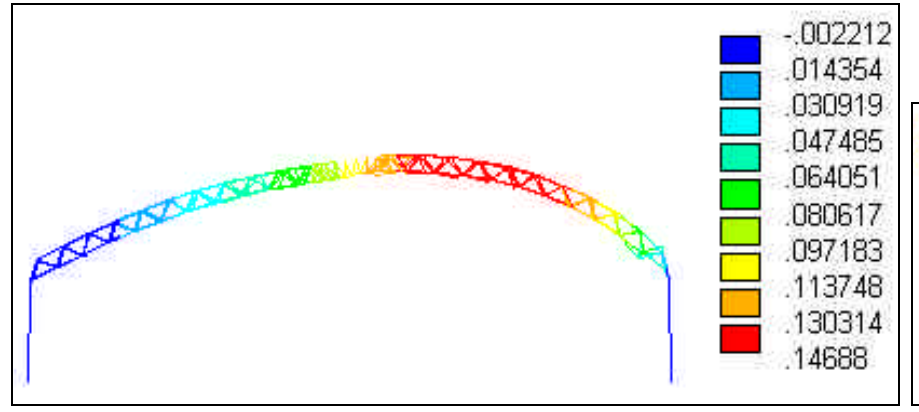

a) Deslocamentos verticais $(\mathrm{m})$

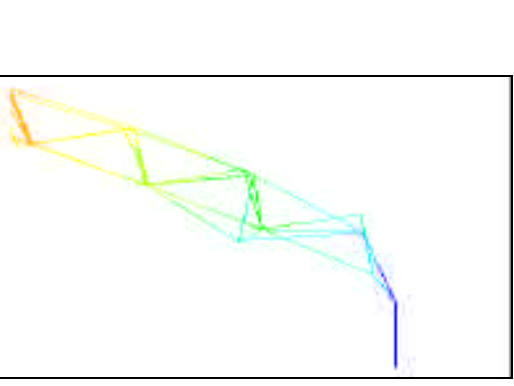

b) Detalhe da ruína

Figura 5.31 - Detalhe da ruína na região analisada

Tabela5.6 - Deslocamentos nodais

\begin{tabular}{|c|c|c|c|}
\hline \multirow{2}{*}{$\begin{array}{c}\text { Posição } \\
\text { de leitura }\end{array}$} & \multicolumn{3}{|c|}{ Deslocamentos (m) } \\
\cline { 2 - 4 } & Número de barras retiradas na região \\
\cline { 2 - 4 } & Nenhuma & 1 barra & 14 barras \\
\hline A & 0.101 & 0.105 & 0.140 \\
\hline B & 0.070 & 0.074 & 0.117 \\
\hline C & 0.025 & 0.026 & 0.048 \\
\hline
\end{tabular}

Novamente podemos perceber que os deslocamentos nas regiões de apoio são pouco influenciados pela retirada dos elementos que foram à ruína. Os valores apresentados na tabela 5.6 indicam um aumento de 
deslocamento nos pontos mais distantes das colunas que servem de apoio, ou seja, os pontos A e B.

Pela análise dos estudos realizados por diferentes autores sobre ruína progressiva, percebe-se uma contradição entre as conclusões obtidas por eles. Uns afirmam que as estruturas espaciais, em particular as cúpulas, possuem um alto grau de redundância e, por esta razão, a perda da estabilidade de um elemento não acarreta a ruína da estrutura. Outros, no entanto, afirmam que este tipo de estrutura apresenta uma forte ruína incremental, ou seja, a perda de instabilidade de um elemento leva à ruína dos elementos vizinhos acarretando no colapso global da estrutura.

O que pode-se observar no exemplo analisado foi que o tipo de ruína e sua propagação dependem, sobretudo, de onde ela se inicia podendo, ou não, levar a estrutura ao colapso. 


\section{Conclusões}

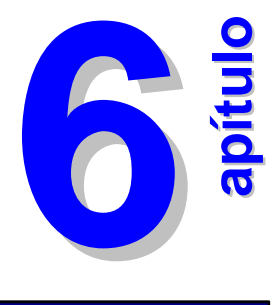

Inicialmente, é interessante ressaltar que esta Dissertação insere-se na linha de pesquisa sobre estruturas espaciais em desenvolvimento no Departamento de Engenharia de Estruturas pelos docentes da Área de Estruturas Metálicas.

A primeira conclusão possível de ser expressa diz respeito ao fato de que as cúpulas são estruturas especiais, não existindo a possibilidade de se recomendar procedimentos gerais que tenham validade para todas as estruturas em função das diferenças inerentes ao projeto arquitetônico, grandes vãos, particularidades das condições de apoio e, principalmente no que diz respeito as ações geradas pelo efeito do vento que, para este tipo de estrutura, é de fundamental importância.

Após a constatação acima, optou-se pela apresentação e discussão de um projeto para este tipo de estrutura, com diâmetro de $80.8 \mathrm{~m} \mathrm{e}$ também, um breve estudo sobre "ruína progressiva", uma vez que este fenômeno pode levar uma estrutura deste tipo ao colapso. 
A análise da "ruína progressiva" originou-se pelo fato de que a maioria das cúpulas existentes no Brasil são compostas de elementos tubulares com sistema de ligação típico.

A presença deste sistema de ligação tem originado um grande número de acidentes em estruturas de cobertura; o mais recente foi o ocorrido em Belém - PA, causando o colapso global de uma estrutura espacial plana constituída por elementos estruturais de alumínio e sistema de ligação típico, parte da cobertura do Aeroporto Internacional de Belém.

Os estudos da "ruína progressiva" desenvolvidos para uma estrutura particular não permitem conclusões passíveis de serem generalizadas. Porém, permite-se afirmar que a presença de anéis intermediários, compostos por elementos com área e inércia superiores aos vizinhos, evitam que, caso ocorra a ruína de algum elemento estrutural se propague para toda a estrutura originando o colapso da mesma; de uma certa forma é uma recomendação para que seja possível intervir em caso de acidente. Obviamente esta intervenção não prevê erros de projeto, execução e montagem.

A necessidade de justificar numericamente o "modo de falha" observado em várias obras que sofreram ruína, em particular as estruturas com nós típicos, foi o fato gerador dos resultados apresentados e descritos no quarto capítulo.

Salienta-se que o modelo utilizado para simular o nó típico do protótipo ensaiado no Laboratório de Estruturas da EESC-USP, apresenta limitações que não podem ser negligenciadas: não consideração da protensão do parafuso, atrito, deslizamento e o modelo reológico simplificado para o aço ( $\sigma \times \varepsilon$ bi-linear).

Mesmo com este modelo ainda simplificado, pode-se concluir pela análise dos resultados dos modelos estudados, que o modo de ruína de estruturas que utilizam o sistema de ligação típico esta diretamente relacionado com problemas localizados nestes nós. Isto se comprova uma vez que, valores diferentes para carga crítica da estrutura foram obtidos em 
função da posição em que o nó foi inserido sendo estes, superiores ou inferiores ao encontrado experimentalmente.

Pode-se então comentar a frase acima descrita:

No modelo 1 - Nó central, pelas particularidades deste nó, ou seja, posição de encontro dos eixos de simetria da estrutura, associado ao fato de que os esforços nas diagonais que concorrem a este nó são nulas, eliminando assim, o esforço cortante, obteve-se um valor elevado para carga crítica da estrutura se comparado com o valor experimental (da ordem de $60 \%$ superior).

Já no modelo 2 - Nó lateral, o valor da carga crítica apresentou-se menor que do modelo anterior (Nó central). Esta diminuição decorre do fato de não continuidade de um dos banzos, associado a influência do esforço cortante nas diagonais, causando uma maior rotação na região nodal. Apesar da diminuição, o valor da carga crítica se manteve superior ao obtido experimentalmente (da ordem de $30 \%$ superior).

No modelo 3 - Nó extremidade, encontrou-se um valor bastante inferior ao obtido experimentalmente (da ordem de 60\% inferior). Justifica-se este fato pela grande concentrações de tensões na região amassada da extremidade da diagonal, tornando-a bastante crítica do ponto de vista numérico, terminando por interromper o processo iterativo da solução nãolinear devido a plastificação precoce desta região . Os resultados indicam que na análise numérica somente a plastificação da diagonal foi a responsável pela carga crítica obtida (da ordem de $\cong 15 \mathrm{kN}$ de força aplicada por nó contra $\cong 40 \mathrm{kN}$ observado experimentalmente), porém observa-se no modelo experimental que os banzos também plastificaram, indicando assim a necessidade de considerar a influência da arruela e pressão de contato devido à protensão do parafuso no modelo numérico.

Quanto ao deslocamentos obtidos nos modelos estudados, percebese um aumento de deslocamento na região que se insere o nó típico modelado com elemento de casca, comprovando a perda de rigidez nesta região. 
Em vista do exposto, conclui-se que rigidez do nó têm influência fundamental da distribuição dos esforços nos elementos e que os modelos teóricos convencionais não são capazes de reproduzir o modo de colapso observado, caracterizado pela rotação excessiva dos nós e plastificação na região estampada dos tubos.

Como sugestão para continuidade deste trabalho propõe-se a melhoria do modelo que representa o nó típico, considerando os efeitos de deslizamento, atrito e protensão causada pelo parafuso, o que permitirá um melhor entendimento deste sistema de ligação. 


\section{Referências bibliográficas}

AMERICAM SOCIETY FOR TESTING AND MATERIALS (1992). ASTM A370: stanrd test methods for tension testing of metalic materials (metric). Philadelphia.

ASSOCIAÇÃO BRASILEIRA DE NORMAS TÉCNICAS (1980). NBR 6120 Cargas para o Cálculo de Estruturas de Edificações: Procedimento. Rio de Janeiro.

ASSOCIAÇÃO BRASILEIRA DE NORMAS TÉCNICAS (1988). NBR 6123 Forças Devidas ao Vento em Edificações: Procedimento. Rio de Janeiro.

ASSOCIAÇÃO BRASILEIRA DE NORMAS TÉCNICAS (1986). NBR 8800 Projeto e Execução de Estruturas de Aço de Edifícios: Método dos Estados Limites. Rio de Janeiro.

EBERLEIN, H. (1984). Single and double-layer MERO domes. In: MAKOWSKI, Z.S. Analysis, design and construction of braced domes. New York, Nichols Plublishing Company. p.541-574.

ELLIOT, A. W. (1984). Triodetic domes. In: MAKOWSKI, Z.S. Analysis, design and construction of braced domes. New York, Nichols Plublishing Company. p. 670-684.

GONÇALVES, R. M. et al (1996). Ação do vento nas edificações. São Carlos. Apostila - Escola de Engenharia de São Carlos, Universidade de São Paulo. 
GONÇALVES, R.M.; FAKURY,R.H.; MAGALHÃES,J.R.M. (1996).

Performance of Tubular Steel Sections Subjected to Compression: Theoretical - Experimental Analysis. In: STABILITY PROBLEMS IN DESIGNING, CONSTRUCTION AND REHABILITATION OF METAL STRUCTURES Ed. by Ronaldo C. Batista, Eduardo de M. Batista and Michèle S. Pfeil. COPPE/UFRJ, Rio de Janeiro, August 1996, p.439449.

MAGALHÃES, J.R.M. (1996). Sobre o projeto e a construção de estruturas metálicas espaciais. São Carlos. Dissertação (Mestrado) - Escola de Engenharia de São Carlos, Universidade de São Paulo.

MAGALHÃES, J.R.M.; MALITE, M. (1996). Alguns Aspectos Relativos ao Projeto e à Construção de Estruturas Metálicas Espaciais. In: Congresso de Engenharia Civil - Universidade Federal de Juiz de Fora, maio 1996. Anais. Juiz de Fora, UFJF-FEC, 1996. V. 1, p.282-291.

MAIOLA, C. H. (1999). Análise teórica e experimental de treliças espaciais constituídas por barras com extremidades estampadas. São Carlos. Dissertação (Mestrado) - Escola de Engenharia de São Carlos, Universidade de São Paulo.

MAKOWSKI, Z.S. (1984). Analysis, design and construction of braced domes. New York, Nichols Plublishing Company. 701p.

MAKOWSKI, Z.S. (1987). Stress Distribution in Prefabricated Double-Layer Grids and their Use for Large-Span Sports Buildings. In SPACE STRUCTURES FOR SPORTS BUILDINGS, proceedings of the international colloquium on space structures for sports buildings, Beijing, oct. 1987. Anais. Ed. by Tien T. Lan and Yuan Zhilian, Elsevier Applied Publishers, London, 1987. 
MAKOWSKI, Z.S. (1993). Space structures - a review of the developments within the last decade. In: FOURTH INTERNATIONAL CONFERENCE ON SPACE STRUCTURES, University of Surrey, Guildford, set 1993. Anais. Ed. by G.A.R. Parke and C.M. Howard, Thomas Telford, London, 1993. p.1623-1630.

MATSUSHITA, F. (1984). Diamond dome systems. In: MAKOWSKI, Z.S. Analysis, design and construction of braced domes. New York, Nichols Plublishing Company. p. 487 - 520.

MATSUSHITA, F. (1993). Study of the elasto-plastic buckling of single-layer domes. In: FOURTH INTERNATIONAL CONFERENCE ON SPACE STRUCTURES, University of Surrey, Guildford, set 1993. Anais. Ed. by G.A.R. Parke and C.M. Howard, Thomas Telford, London, 1993.

MULLORD, P. (1984). Introdução to the analysis of braced domes. In: MAKOWSKI, Z.S. Analysis, design and construction of braced domes. New York, Nichols Plublishing Company. p. 87 - 95.

MUTOH, I.; KATO, S. (1993). Comparasion of buckling loads between single-layer lattice domes and spherical shells. In: FOURTH INTERNATIONAL CONFERENCE ON SPACE STRUCTURES, University of Surrey, Guildford, set 1993. Anais. Ed. by G.A.R. Parke and C.M. Howard, Thomas Telford, London, 1993.

SHIBATA, R. et al. (1993). Experimental study on the ultimate strength of single-layer reticular domes. In: FOURTH INTERNATIONAL CONFERENCE ON SPACE STRUCTURES, University of Surrey, Guildford, set 1993. Anais. Ed. by G.A.R. Parke and C.M. Howard, Thomas Telford, London, 1993. 
SOUZA, A.S.C. (1998). Contribuição ao estudo das estruturas metálicas espaciais. São Carlos. Dissertação (Mestrado) - Escola de Engenharia de São Carlos, Universidade de São Paulo.

UEKI, T. ; MATSUSHITA, F. (1993). Design procedure for large single-layer latticed domes. In: FOURTH INTERNATIONAL CONFERENCE ON SPACE STRUCTURES, University of Surrey, Guildford, set 1993. Anais. Ed. by G.A.R. Parke and C.M. Howard, Thomas Telford, London, 1993.

WALKER, H.B. (1984). Design and construction of braced domes. In: MAKOWSKI, Z.S. Analysis, design and construction of braced domes. New York, Nichols Plublishing Company. p.461-485.

ZHAO, H. L.; HUANG, W. M. A method to calculate the critical loads of single layer shollow lattice domes with initial imperfections. In: FOURTH INTERNATIONAL CONFERENCE ON SPACE STRUCTURES, University of Surrey, Guildford, set 1993. Anais. Ed. by G.A.R. Parke and C.M. Howard, Thomas Telford, London, 1993. 